\title{
EVALUASI KENYAMANAN AUDIAL \\ PADA KAWASAN PERUMAHAN \\ DI KOTA BOGOR
}

\section{DAMARIA WIDASARI}

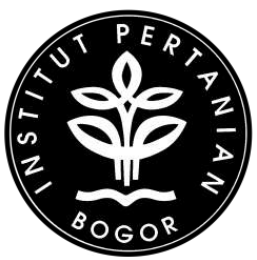

SEKOLAH PASCASARJANA

INSTITUT PERTANIAN BOGOR

BOGOR

2020 



\section{PERNYATAAN MENGENAI TESIS DAN SUMBER INFORMASI SERTA PELIMPAHAN HAK CIPTA}

Dengan ini saya menyatakan bahwa tesis berjudul Evaluasi Kenyamanan Audial pada Kawasan Perumahan di Kota Bogor adalah benar karya saya dengan arahan dari komisi pembimbing dan belum diajukan dalam bentuk apa pun kepada perguruan tinggi mana pun. Sumber informasi yang berasal atau dikutip dari karya yang diterbitkan maupun tidak diterbitkan dari penulis lain telah disebutkan dalam teks dan dicantumkan dalam Daftar Pustaka di bagian akhir tesis ini.

Dengan ini saya melimpahkan hak cipta dari karya tulis saya kepada Institut P्र́⿴囗十

Bogor, Agustus 2020

Damaria Widasari

NIM A451170141 


\section{RINGKASAN}

DAMARIA WIDASARI. Evaluasi Kenyamanan Audial pada Kawasan Perumahan di Kota Bogor. Dibimbing oleh INDUNG SITTI FATIMAH dan NIZAR NASRULLAH.

Pembangunan kawasan permukiman dan perumahan di Kota Bogor semakin meningkat seiring dengan pertambahan jumlah penduduk dan ditandai oleh pengembangan beberapa jalan. Salah satu permasalahan pada perumahan adalah kebisingan. Kebisingan di area perumahan membawa berbagai gangguan kenyamanan bagi penghuninya, khususnya kenyamanan audial. Tujuan dari penelitîanan ini adalah mengukur dan menganalisis distribusi bising kawasan perumähan, menganalisis persepsi penduduk perumahan terhadap bising, serta menemukan penghalang yang efektif untuk mereduksi kebisingan di kawasan perumathan tersebut.

E్ Fasil analisis menunjukkan bahwa tingkat kebisingan di Perumahan IPB 1 Baranangsiang rata-rata, selama hari kerja dan hari libur, sebesar $87.2 \mathrm{~dB}$. Berdașarkan analisis persamaan regresi, distribusi bising pada berbagai jarak dari jalan, di Perumahan IPB 1 Baranangsiang memiliki $\mathrm{R}$ square atau koefisien deterninasi sebesar 0.763. Hal ini menunjukkan bahwa variable jarak mempēngaruhi kebisingan sebesar $76 \%$ dan $24 \%$ merupakan variable lain. Persamaan linear yang didapatkan adalah $\mathrm{Y}=69.63-0.35 \mathrm{X}$, menunjukkan bahwa apabila variable jarak mengalami penambahan $1 \mathrm{~m}$ maka akan menurunkan variabFe kebisingan sebesar $0.35 \mathrm{~dB}$. Dari hasil analisis regresi, jarak mempengaruhi nilai kebisingan, semakin dekat dengan sumber kebisingan maka nilai kebisingannya akan semakin besar begitu juga sebaliknya.

Hasil analisis lainnya adalah gangguan yang sering dirasakan oleh penduduk Perumahan IPB 1 Baranangsiang, seperti mengganggu konsentrasi, tidak nyaman, dan gangguan saat tidur. Terdapat hubungan yang signifikan antara tingkat bising dengan gangguan kebisingan berupa sakit kepala, tidak nyaman, gangguan saat tidur, dan harus berbicara keras. Penduduk perumahan tersebut merasa terganggu dengan adanya suara bising dari kendaraan yang melintas saat berada di halaman rumah dengan perolehan suara $60 \%$.

Penyusunan penghalang (barrier) yang efektif dalam meredam kebisingan adalah susunan pohon berkelompok dan susunan beberapa baris semak berbentuk jalur. Susunan pohon berkelompok efektif mereduksi kebisingan di frekuensi tinggi, $5000 \mathrm{~Hz}-8000 \mathrm{~Hz}$, dengan nilai pengurangan suara tertinggi sebesar 13.42 $\mathrm{dB}$ atau sekitar $12.21 \%$. Susunan semak berbentuk jalur efektif mereduksi kebisingan pada frekuensi $315 \mathrm{~Hz}-8000 \mathrm{~Hz}$, dengan nilai pengurangan suara tertinggi sebesar $19.10 \mathrm{~dB}$ atau sekitar $11.27 \%$. Susunan pohon berkelompok lebih efektif dalam meredam bising apabila posisi sumber suara lebih tinggi daripada posisi penempatan barrier, namun apabila posisi sumber suara berada pada kétinggian yang sama dengan posisi penempatan barrier maka susunan semak berbentuk jalur lebih efektif mereduksi bising. Pola penyusunan barrier tanaman yang tepat di lingkungan perumahan akan memberikan kenyamanan secarâaudial bagi penduduk perumahan.

a

Kata kunci: distribusi bising, kenyamanan audial, penyusunan tanaman. 


\section{SUMMARY}

DAMARIA WIDASARI. Evaluation of Audial Comfort in Residential Areas in Bogor City. Supervised by INDUNG SITTI FATIMAH and NIZAR NASRULLAH.

The development of residential areas and housing in Bogor city is increasing in line with the growth of population and characterized by the development of street infrastructures, one of problems in that residential environment is noise. Noise in residential areas brings a variety of distruptions to comfort for residents, especially audial comfort. This study aimed to measure and analyze the noise distribution of residential areas, analyze the perceptions of housing residents, and $\vec{t}$ find the effective of barriers to reduce noise in residential areas.

The results showed that the average noise level, during weekdays and Weekend, was $87.2 \mathrm{~dB}$. Based on the analysis of noise distribution in varied distance from the street, noise distribution at various distances from the street, in the Housing has $\mathrm{R}$ square or a determination coefficient of 0.763 . This shows that Whe distance variable affects noise by $76 \%$ and $24 \%$ was by other variable. The linear equation obtained is $\mathrm{Y}=69.63-0.35 \mathrm{X}$, indicating that if the distance Wariable increases by $1 \mathrm{~m}$ it will reduce the variable noise by $0.35 \mathrm{~dB}$. Finally, distance affects the value of noise, the closer to the noise source the greater the noise value and vice versa.

The other results are the disturbances that often felt by the residents, such as đisturbing concentration, discomfort, and disturbance during sleep. There is a significant relationship between noise level with noise disorder, such as headache, discomfort, disturbance during sleep, and speak loudly. The residents were disturbed by the traffic noise with votes $60 \%$.

The effective barrier types in reducing noise were the arrangement of trees in groups and the arrangement several rows of bushes in line shape. The group tree arrangement effectively reduced noise at high frequencies, $5000 \mathrm{~Hz}-8000$ $\mathrm{Hz}$, with the highest insertion loss is $13.42 \mathrm{~dB}$ or $12.21 \%$. The line shape bush arrangement effectively reduced noise at frequencies $315 \mathrm{~Hz}-8000 \mathrm{~Hz}$, with the highest insertion loss is $19.10 \mathrm{~dB}$ or $11.27 \%$. The group tree arrangement wass more effective in reducing noise when the elevation of the sound source was higher than the elevation of the barrier placement, but if the sound source elevation was the same as the elevation of barrier placement then the arrangement of bushes in line shape was more effective at reducing noise. The pattern of composing the right plant barrier can reduce noise caused by passing vehicles in a residential environment, so it will provide audial comfort for the residential population.

Keywords: noise distribution, audial comfort, plant preparation. 


\section{(C) Hak Cipta Milik IPB, Tahun 2020}

\section{Hak Cipta Dilindungi Undang-Undang}

Dilarang mengutip sebagian atau seluruh karya tulis ini tanpa mencantumkan atau menyebutkan sumbernya. Pengutipan hanya untuk kepentingan pendidikan, penelitian, penulisan karya ilmiah, penyusunan laporan, penulisan kritik, atau tinjauan suatu masalah; dan pengutipan tersebut tidak merugikan kepentingan $I P B$

Dilarang mengumumkan dan memperbanyak sebagian atau seluruh karya tulis ini dalam bentuk apa pun tanpa izin IPB 


\title{
EVALUASI KENYAMANAN AUDIAL \\ PADA KAWASAN PERUMAHAN \\ DI KOTA BOGOR
}

DAMARIA WIDASARI

\author{
Tesis \\ sebagai salah satu syarat untuk memperoleh gelar \\ Magister Sains \\ pada \\ Program Studi Arsitektur Lanskap
}

\author{
SEKOLAH PASCASARJANA \\ INSTITUT PERTANIAN BOGOR \\ BOGOR \\ 2020
}




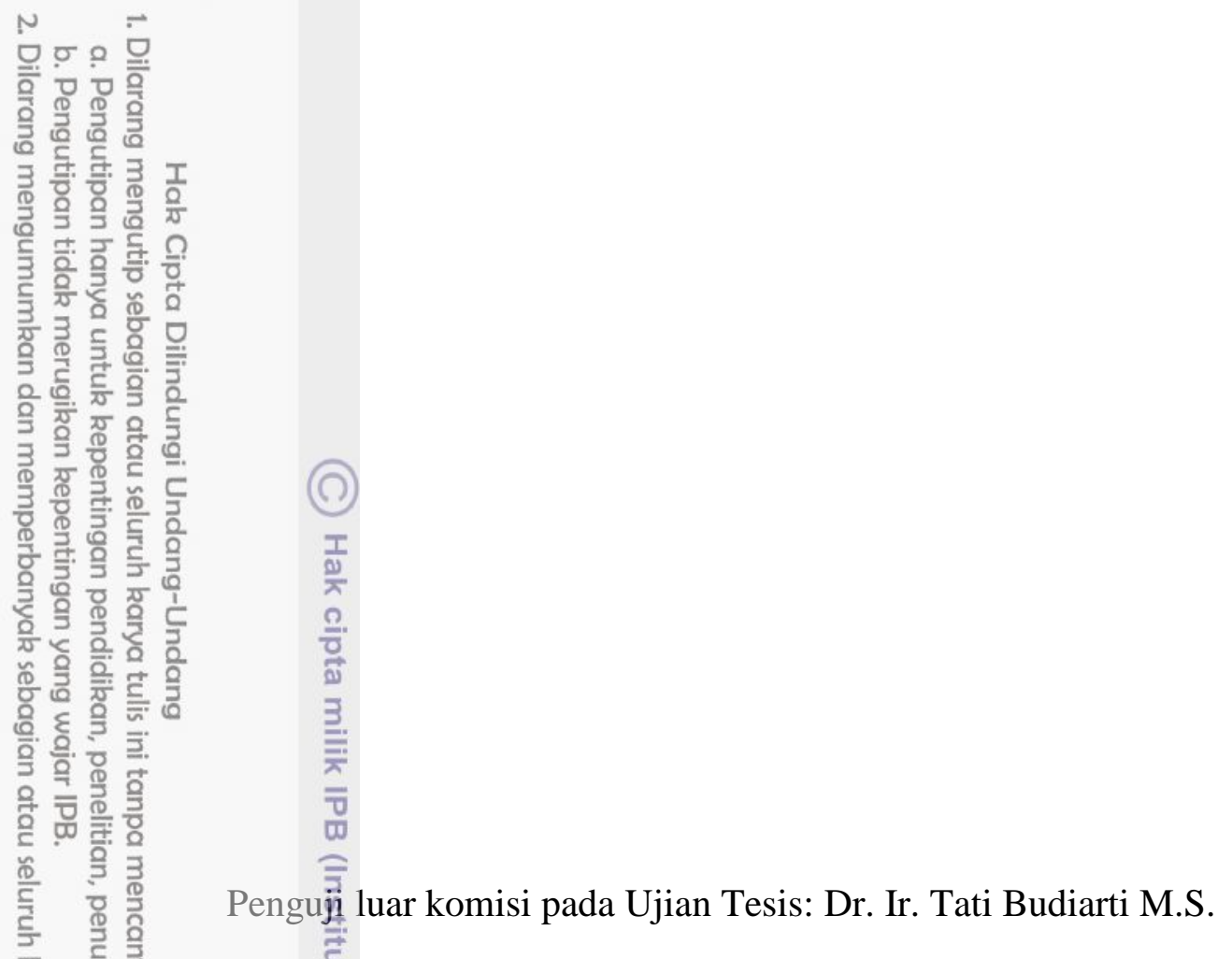




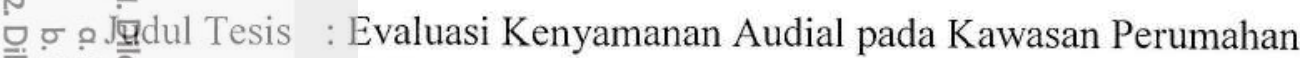

di Kota Bogor

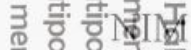

A451170141

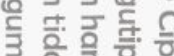

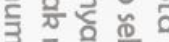

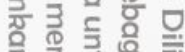

응 든 홍

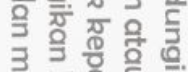

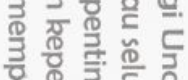

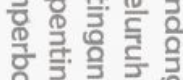

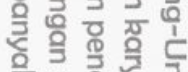

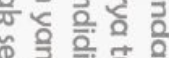

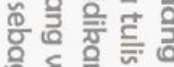

을. 응. Ir Indung Sitti Fatimah, MSi

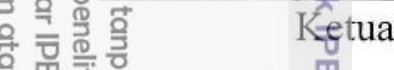

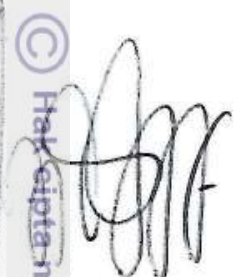

Disetujui oleh

Komisi Pembimbing

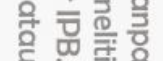

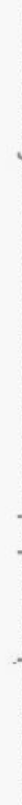

Diketahui oleh

\section{Dr Ir Nizar Nasrullah, MAgr \\ Anggota}

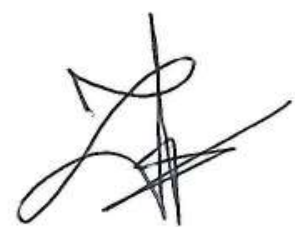

产

m

Dekan Sekolah Pascasarjana

Arsitektur Lainskap

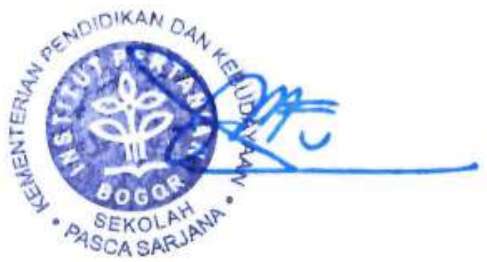

Prof Dr Ir Anas Miftah Fauzi, MEng

Tanggal Lulus: 24 OCT 2020 


\section{PRAKATA}

Puji dan syukur penulis panjatkan kehadirat Allah subhanahu wa ta'ala atas segala karunia-Nya sehingga tesis ini berhasil diselesaikan. Tema yang dipilih dalam tesis ini adalah kebisingan di perumahan, dengan judul Evaluasi Kenyamanan Audial pada Kawasan Perumahan di Kota Bogor. Penelitian ini diawali dengan menganalisis distribusi bising pada perumahan IPB 1 Baranangsiang melalui penentuan titik pengukuran, mengukur tingkat bising, membuat peta sebaran kebisingan, melakukan penelitian simulasi untuk mengukur

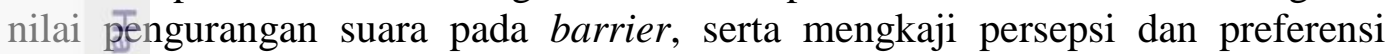
masyar̂akat terhadap kebisingan di lingkungan perumahan mereka. Oleh karena itu, dapat dibuat suatu rekomendasi yang tepat untuk mengurangi kebisingan pada Rawasan perumahan yang banyak terdapat sumber bising. Penelitian ini merupăkan Penelitian Tesis Magister, Program Studi Arsitektur Lanskap, Fakultas Pertanīan, Sekolah Pascasarjana, Institut Pertanian Bogor.

Penulis mengucapkan terima kasih kepada Dr Ir Indung Sitti Fatimah, MSi dan (अ) Ir Nizar Nasrullah, MAgr selaku Komisi Pembimbing yang telah membẹrikan bimbingan, arahan, masukan, dukungan, nasehat, dan waktu serta ilmu चुang sangat bermanfaat dalam penyelesaian tesis ini. Penulis juga mengữeapkan terima kasih kepada Ir Wisnu Eka Yulyanto selaku pembimbing laboraforium atas bimbingan, masukan, bantuan, nasehat, serta atas izin pemakaian fasilitas Laboratorium Kebisingan dan Getaran, Pusat Penelitian dan Pengembangan Kualitas dan Laboratorium Lingkungan (P3KLL), Kementerian Lingk dan Geknologi (PUSPIPTEK), Serpong, Tangerang Selatan. Penulis juga mengucapkan terima kasih kepada semua pihak yang telah banyak membantu dalam memberikan arahan dan petunjuk selama penelitian serta penyusunan tesis ini.

Hasil penelitian ini diharapkan dapat bermanfaat bagi berbagai pihak, seperti pemerintah dan masyarakat pada perumahan IPB 1 Baranangsiang di Kota Bogor, dalam menerapkan bentuk pengembangan lanskap kawasan perumahan. Hal tersebut juga diharapkan dapat diterapkan pada kawasan perumahan lain yang memiliki tipologi serupa dan banyak sumber bising. Semoga karya ilmiah ini bermanfaat.

Bogor, Agustus 2020

Damaria Widasari 


\section{DAFTAR ISI}

DAFTAR TABEL $\quad$ xi

DAFTAR GAMBAR - xi

DAFTAR LAMPIRAN X

PENDAHULUAN 1

Latar Belakang 1

Perumusan Masalah $\quad 3$

Tujuan Penelitian $\quad 4$

Manfaat Penelitian 4

Ruang Lingkup Penelitian $\quad 4$

Kerangka Pikir Penelitian $\quad 4$

$\begin{array}{ll}\text { TINJAUAN PUSTAKA } & 6\end{array}$

Perumahan Sekitar Jalan Layang dan Jalan Tol 6

Bising $\quad 6$

Sumber Bising di Jalan $\quad 8$

Analisis Frekuensi $\quad 9$

Dampak Kebisingan $\quad 9$

$\begin{array}{lr}\text { Pengendalian Bising } & 10\end{array}$

Karakteristik Tanaman Pereduksi Bising 13

METODOLOGI 15

Waktu dan Lokasi Penelitian $\quad 15$

Alat dan Bahan Penelitian $\quad 16$

Rancangan Penelitian 16

Metode Analisis Data $\quad 22$

4 HASIL DAN PEMBAHASAN 25

Kondisi Umum $\quad 25$

Analisis Tingkat Kebisingan $\quad 27$

Persepsi dan Preferensi 36

Simulasi Penggunaan Penghalang (Barrier) 48

Perumusan Rekomendasi $\quad 66$

$\begin{array}{ll}\text { SIMPULAN DAN SARAN } & 70\end{array}$

Simpulan $\quad 70$

$\begin{array}{ll}\text { Saran } & 70\end{array}$

DAFTAR PUSTAKA

$\begin{array}{ll}\text { EAMPIRAN } & 75\end{array}$

RIWAYAT HIDUP $\quad 89$ 


\section{DAFTAR TABEL}

Baku tingkat kebisingan 8

2 Efektifitas pengurangan kebisingan oleh berbagai macam tanaman 14

Alat dan bahan penelitian $\quad 16$

Pengaruh jarak dan waktu terhadap nilai kebisingan $\quad 34$

Jumlah kendaraan yang melintas pada kawasan perumahan 37

Persepsi penduduk yang tinggal di jarak $<10 \mathrm{~m} \quad 37$

Persepsi penduduk yang tinggal di jarak $25 \mathrm{~m} \quad 38$

Persepsi penduduk yang tinggal di jarak $50 \mathrm{~m} \quad 38$

9 Hब্ষsil pengukuran intensitas kebisingan 18 titik pengukuran 39

10 Distribusi responden yang mengalami gangguan fisiologi 40

11 Distribusi responden yang mengalami gangguan psikologi 41

12 Dî̉stribusi responden yang mengalami gangguan komunikasi 42

13 Hăssil uji bivariate terhadap gangguan fisiologi 43

14 Hầsil uji bivariate terhadap gangguan psikologi 43

15 Hăsil uji bivariate terhadap gangguan komunikasi 44

16 Persepsi mengenai kenyamaan audial lingkungan perumahan 44

17 Pẹrbedaan SPL sumber bunyi on dan off pada frekuensi $20-20000 \mathrm{~Hz} \quad 49$

18 NḦai IL dari ketiga model penyusunan tanaman 63

\section{DAFTAR GAMBAR}

1 Baggan kerangka pikir 5

2 Dîagram blok sound level meter $\quad 7$

3 Jalur suara yang digunkaan untuk menghitung perbedaan jalur 11

4 Grafik koreksi potensial barrier potensial 11

5 Tanaman dikombinasi dengan tanaman lain untuk memperbesar kerimbunan

6 Tanaman dikombinasi dengan gundukan tanah dan dinding 12

7 Lokasi penelitian 15

8 Ilustrasi pengukuran bising 17

9 Denah ruang semi bebas gema 18

10 Ilustrasi kondisi lapang dalam ruang semi bebas gema 18

11 Ilustrasi model penyusunan tanaman 19

12 Iastrasi simulasi pengukuran barrier 21

13 Atat yang digunakan dalam pengukuran simulasi 22

14 Bagan alur penelitian 22

15 Bagian utara dan timur Perumahan IPB 1 Baranangsiang 25

16 Bagian selatan Perumahan IPB 1 Baranangsiang 25

17 Tingkat kebisingan rata-rata siang hari $\left(\mathrm{L}_{\mathrm{s}}\right) \quad 27$

18 Tingkat kebisingan pada hari libur (Minggu) 28

19 Tingkat kebisingan pada hari kerja I (Senin) 28

20 Tingkat kebisingan pada hari kerja II (Rabu) 29

21 Jatur transek pada lokasi penelitian $\quad 29$

22 Perbandingan jalur transek I - IV 30

23 Perbandingan jalur transek V dan VI 32 
24. Grafik persamaan regresi linear

25 Pola penyebaran bising pada sumber bagian utara dan timur 32

26 Peta sebaran bising Perumahan IPB 1 Baranangsiang 32

27 Tingkat kebisingan yang ditoleransi pada kawasan pemukiman $\quad 45$

28 Upaya pengendalian kebisingan di lingkungan perumahan 46

29 Tipe barrier penataan tanaman dan pagar tanaman 46

30 Penataan tanaman pada halaman rumah untuk mereduksi bising 47

31 Pola penataan tanaman menyebar di halaman rumah penduduk 47

32 Halaman rumah yang efektif mereduksi bising 47

33 Kenyamanan lingkungan perumahan yang diinginkan responden 48

34. Pengukuran SPL di ruang semi bebas gema 48

35 IL penyusunan pohon berkelompok 51

36 Penyusunan pohon berkelompok 51

37 IL penyusunan semak berkelompok

3.8 Penyusunan semak berkelompok 53

$\overline{\overline{3}}$ IL kombinasi susunan berkelompok $\quad 54$

通0 Penyusunan kombinasi tanaman berkelompok $\quad 54$

41 IL penyusunan pohon menyebar $\quad 55$

42 Penyusunan pohon menyebar $\quad 55$

43 IL penyusunan semak menyebar $\quad 56$

44. Penyusunan semak menyebar $\quad 57$

95 IL kombinasi susunan menyebar $\quad 58$

番6 Penyusunan kombinasi tanaman menyebar 58

צ̧7 IL penyusunan pohon bentuk jalur $\quad 59$

48 Penyusunan pohon berbentuk jalur $\quad 59$

๕9 IL penyusunan semak bentuk jalur $\quad 60$

$\begin{array}{ll}50 \text { Penyusunan semak berbentuk jalur } & 61\end{array}$

51 IL kombinasi susunan bentuk jalur $\quad 62$

52 Penyusunan kombinasi tanaman berbentuk jalur $\quad 62$

53 Ilustrasi rekomendasi penataan barrier $\quad 69$

\section{DAFTAR LAMPIRAN}

1 Tingkat kebisingan setiap titik pengukuran 75

Karakteristik responden Perumahan IPB 1 Baranangsiang 77

$\begin{array}{ll}\text { Propagasi suara merk speaker } & 78\end{array}$

IL pohon berkelompok pada frekuensi $63-8000 \mathrm{~Hz} \quad 80$

IL semak berkelompok pada frekuensi $63-8000 \mathrm{~Hz} \quad 81$

IL kombinasi tanaman berkelompok pada frekuensi $63-8000 \mathrm{~Hz} \quad 82$

IL pohon menyebar pada frekuensi $63-8000 \mathrm{~Hz}$

IL semak menyebar pada frekuensi $63-8000 \mathrm{~Hz}$

IL kombinasi tanaman menyebar pada frekuensi $63-8000 \mathrm{~Hz} \quad 85$

IL pohon berbentuk jalur pada frekuensi $63-8000 \mathrm{~Hz}$

IL semak berbentuk jalur pada frekuensi $63-8000 \mathrm{~Hz} \quad 87$

12 IL kombinasi tanaman berbentuk jalur pada frekuensi $63-8000 \mathrm{~Hz} \quad 88$ 



\section{PENDAHULUAN}

\section{Latar Belakang}

Perkembangan kota di Indonesia semakin meningkat seiring dengan pesatnya pembangunan. Pembangunan kota sering lebih banyak dicerminkan oleh adanya perkembangan fisik kota yang lebih banyak ditentukan oleh sarana dan prasarana, seperti jalan raya, jalan tol, transportasi, kawasan industri, kawasan perdagangan, dan pemukiman. Pembangunan kota pada saat ini memiliki kecenderungan untuk meminimalkan ruang terbuka hijau, karena lahan-lahan Rosong banyak dialih fungsikan menjadi pertokoan, pemukiman, industri, dan bangunan lainnya (Dahlan 2004). Menurut penelitian yang dilakukan Suryadi et al (2008), pada tahun 1972 luas RTH yang diperoleh dari landcover hutan, kebun campuran, dan semak adalah 8060.09 ha atau sekitar 68\% dari luas kota Bogor. $\bar{K}$ emudian pada tahun 2005 terjadi penurunan luas RTH yang diperoleh dari Fandcover hutan, kebun campuran, semak, dan sawah yaitu sebesar 6206.35 ha atau sekitar 52\% dari luas Kota Bogor. Hal ini berarti dalam kurun waktu 33 tahun trjadi penurunan RTH sebesar $16 \%$ atau sekitar $0.48 \%$ per tahun di Kota Bogor.

Kota Bogor merupakan salah satu kota di Indonesia yang terus mengalami perkembangan dengan tingkat pertumbuhan penduduk dan pembangunan fisik Rota yang cukup tinggi. Hal ini disebabkan oleh beberapa faktor seperti (1) letak Kota Bogor yang sangat strategis, yaitu dekat dengan Jakarta yang merupakan Gukota negara Indonesia, (2) kedudukan Kota Bogor sebagai bagian dari sistem metropolitan Jabodetabek (Jakarta-Bogor-Depok-Tangerang-Bekasi), serta (3) Redudukan Kota Bogor sebagai kota satelit yang menunjang Kota Jakarta. Kondisi đemikian menjadikan Kota Bogor sebagai pilihan bagi penduduk baik yang datang dari sekitar Bogor maupun perantau dari daerah-daerah lainnya yang menjadikan Kota Bogor dan Jakarta sebagai sumber mata pencaharian. Kondisi tersebut memberikan dampak luas bagi perkembangan Kota Bogor. Namun, jika perkembangan ini tidak diseimbangkan dengan penataan dan pembangunan lanskap perkotaan yang berwawasan lingkungan, akan mengakibatkan terjadinya degradasi lingkungan.

Letak Kota Bogor yang strategis merupakan potensi untuk pengembangan permukiman, pertumbuhan ekonomi dan pelayanan, perdagangan, transportasi, komunikasi, dan pariwisata. Berdasarkan analisis data BPS Kota Bogor tahun 2017, Kota Bogor memiliki jumlah penduduk 1064687 jiwa dengan kepadatan penduduk $8985 \mathrm{jiwa} / \mathrm{km}^{2}$. Dengan jumlah penduduk yang mencapai lebih dari 1 (juta jiwa, Kota Bogor menjadi salah satu kota di Indonesia dengan kategori Kota Metropolitan, yaitu wilayah perkotaan hasil perwujudan perkembangan alamiah dari suatu kawasan permukiman yang berkembang sangat pesat (Angotti 1993).

Pada tahun 1976 dikeluarkan Instruksi Presiden tentang Jabodetabek yang menetapkan Kota Bogor sebagai salah satu kota penyangga (hinterland) ibukota dan sebagai kota permukiman (dormitory town). Semakin mudahnya akses dan singkatnya waktu tempuh Jakarta-Bogor menyebabkan Bogor menjadi salah satu đaerah tujuan untuk bermukim. Kota Bogor tumbuh sebagai kota berbasis Dermukiman para pekerja yang mencari nafkah di Jakarta. Perkembangan permukiman skala besar ditandai oleh pesatnya permintaan akan lahan untuk 
kegiatan usaha atau tempat hunian, khususnya kawasan perumahan sebagai akibat perkembangan ekonomi yang cukup pesat di Kota Jakarta, sehingga perkembangan permukiman di wilayah sub-urban Jabotabek yang terjadi pada umumnya masih punya ketergantungan yang sangat tinggi dengan Kota Jakarta. Pembangunan perumahan di Kota Bogor ditetapkan sebagai hinterland Jakarta lebih didasarkan pada kedekatan dan kemudahan akses transportasi bagi para commuter (Tohjiwa et al 2010).

Berdasarkan RTRW Kota Bogor, sebagian besar wilayah Kota Bogor adalah permukiman. Permukiman tersebut terdiri dari permukiman kepadatan tinggi, permukiman kepadatan sedang, dan permukiman kepadatan rendah. Pembangunan kawasān permukiman dan perumahan di perkotaan semakin tahun semakin meningkat sejalan dengan pertumbuhan jumlah penduduk. Untuk menarik minat konsumen agar permukiman dan perumahan yang ditawarkan laku, pihak pengembang berusaha melengkapi infrastruktur yang diantaranya adalah prasarăna jalan. Pada satu sisi jalan memberikan kemudahan bagi masyarakat akan le butuhan transportasi, namun demikian disisi lain keberadaan mobil dan motor tentunya membawa berbagai gangguan dan kenyamanan bagi penghuni rumahe

Salah satu bentuk gangguan yang ditimbulkan dari semakin meningkatnya pembatitgunan dan aktivitas manusia adalah kebisingan. Kebisingan telah menjadi masalah umum di perkotaan. Suara tersebut dapat bersumber dari mesin untuk konstruksi infrastruktur dan transportasi, namun sebagian besar kebisingan bersumber dari transportasi, terutama kendaraan bermotor. Berdasarkan SK Mentefi Negara Lingkungan Hidup No: KepMen-48/MEN.LH/11/1996, kebisiggan merupakan bentuk suara yang tidak diinginkan karena menimbulkan ganggţan kesehatan manusia dan kenyamanan lingkungan, termasuk ternak, satwa, flan sistem alam. Menurut Workplace Health and Safety (2015), kebisingan dapat mempengaruhi fungsi telinga bagian dalam, yang dapat menyebabkan kehilangan pendengaran sementara. Setelah beberapa waktu jauh dari kebisingan, pendengaran dapat dipulihkan. Namun jika paparan kebisingan dibiarkan lebih lanjut, telinga secara bertahap akan kehilangan kemampuannya untuk pulih dan mengakibatkan kehilangan pendengaran secara permanen. Tingkat kebisingan lalu lintas jalan pada permukiman di tiga kota, yaitu Kota Bekasi, Bogor, dan Tangerang rata-rata diatas 70 dBA (Depkes RI 1994 dalam Ikron et al 2007), seharusnya tingkat kebisingan kawasan perumahan dan permukiman adalah 55 dBA menurut standar lingkungan hidup. Kebisingan telah menjadi masalah umumdi kawasan permukiman, yang dapat menyebabkan tuli dan mempengaruhi mentap kesehatan, seperti stress dan tekanan jiwa. Jika tekanan jiwa tidak dapat disembuhkan akan berdampak pada menurunnya kesehatan fisik.

Pengurangan dampak negative dari kebisingan adalah dengan penempatan dinding penghalang kebisingan. Penelitian telah menunjukkan bahwa suatu dinding penghalang harus ditempatkan sedekat mungkin dengan sumber pencemar suara tuntuk mencapai pengurangan suara yang maksimum. Pada dasarnya, penghatang kebisingan terdiri dari tiga jenis (1) membentuk gundukan tanah seperti, tanggul, (2) dinding penghalang, dan (3) kombinasi tanggul dengan dinding (Hakim 2006). Selain itu, tingkat kebisingan juga dapat dikontrol oleh vegetasi tergantung pada (1) jenis spesies, tinggi tanaman, kepadatan, dan jarak tumbuh;; (2) factor iklim, yaitu kecepatan angin, suhu, dan kelembaban; dan (3) 
jenis suara, asal dan tingkat decibel (tingkat intensitas). Gelombang suara diserap oleh daun, dahan, ranting pohon, dan semak-semak (Pudjowati et al 2013).

Keberadaan vegetasi di dalam kota secara mendasar diperlukan justru bukan sekedar untuk keindahan semata namun lebih jauh lagi untuk tujuan kenyamanan dan kesehatan manusia pengguna kota. Menurut Karyono (2005) terdapat empat jenis kenyamanan manusia yang berkaitan dengan keberadaan taman kota, yaitu kenyamanan spasial, kenyamanan visual, kenyamanan termal, dan kenyamanan audial. Kenyamanan spasial yaitu taman diharapkan mampu mewadahi aktifitas informal warga seperti halnya istirahat, duduk, ngobrol, bermain, dan sebagainya. Renyamanan visual yaitu taman perlu dirancang agar indah, dimana pertimbangan estetika perlu diperhatikan sehingga secara visual dapat dinikmati oleh warga kota. Kenyamanan termal yaitu taman dapat mengurangi ketidaknyamanan yang diakibatkan oleh iklim setempat, untuk daerah beriklim dingin, perlu dirancang agar suhu udara taman dapat menjadi lebih tinggi sementara daerah beriklim tropis, diharapkan suhu udara di dalam taman dapat lebih rendah dari suhu ratapata kota. Kenyamanan audial yaitu taman kota yang tersusun oleh berbagai jenis vegetasi diharapkan dapat membantu mengurangi polusi suara yang dikeluarkan kendaraan bermotor dan bising kota. Terkait permasalahan kebisingan di p̉erkotaan dan kenyamanan audial, baku mutu kebisingan perumahan dan permukiman sudah diatur dalam Keputusan Menteri Lingkungan Hidup Nomor 48/MENLH/11/1996 tentang Baku Tingkat Kebisingan, dinyatakan bahwa baku mutu perumahan dan permukiman adalah sebesar $55 \mathrm{~dB}$.

Informasi mengenai kenyamanan audial di kawasan perumahan dapat Menjadi informasi tambahan dan panduan bagi arsitek lanskap dalam melakukan Berencanaan, perancangan, dan pengelolaan lanskap perkotaan yang tidak hanya famah bagi manusia, tetapi juga bagi makhluk hidup lainnya dan lingkungan yang aman dan nyaman. Rekomendasi berupa konsep kawasan permukiman dalam menciptakan kenyamanan audial dapat menjadi pedoman, panduan, dan referensi dalam melakukan perencanaan, perancangan, dan pengelolaan lanskap kawasan permukiman dalam mengendalikan kebisingan.

\section{Perumusan Masalah}

Permasalahan yang dikaji dalam penelitian ini adalah:

1. berapa tingkat bising kawasan permukiman pada lokasi penelitian?

2. bagaimana persepsi penduduk mengenai kebisingan yang terjadi di lingkungan mereka?

3. seperti apa bentuk penghalang tanaman dan gundukan tanah yang efektif dalam mengurangi bising?

4. kawasan permukiman seperti apa yang memberikan kenyamanan audial bagi penduduk di lokasi penelitian?

Perlu dilakukan pengukuran dan analisis tingkat kebisingan, perhitungan pengurangan suara pada barrier gundukan tanah dan tanaman, serta analisis persepsi penduduk pada kawasan permukiman di Kelurahan Baranangsiang, Kota Bogor. Dengan adanya informasi tersebut dapat membantu dalam membuat rekomendasi konsep kawasan permukiman dalam menciptakan kenyamanan audial di Kelurahan Baranangsiang. 


\section{Tujuan Penelitian}

Tujuan dari penelitian ini adalah:

1. mengukur dan menganalisis distribusi bising pada kawasan perumahan IPB 1 Baranangsiang di Kota Bogor;

2. menganalisis jenis gangguan kebisingan yang dirasakan penduduk perumahan IPB 1 Baranangsiang di Kota Bogor;

3. menganalisis nilai pengurangan suara pada barrier tanaman yang efektif dalam mengurangi bising; dan

4. menyusun rekomendasi konsep RTH pada permukiman dalam menciptakan kenyamanan audial.

을

耳asil dari penelitian ini diharapkan dapat digunakan sebagai pedoman, panduān, dan referensi bagi berbagai pihak khususnya arsitek lanskap, planologi, dan pêngelola Kota Bogor dalam melakukan perencanaan, perancangan, dan penge $\bar{b}$ laan lanskap dalam menciptakan kenyamanan audial, khususnya di tempaËtempat yang membutuhkan ketenangan seperti permukiman, rumah sakit, sekola dan tempat ibadah.

\section{Ruang Lingkup Penelitian}

Batasan penelitian ini meliputi lingkup kajian dan lingkup wilayah kajian. Lingkûp kajian penelitian ini dibatasi pada pengukuran tingkat bising, analisis tingkat bising, perhitungan pengurangan suara pada penghalang gundukan tanah dan tanaman, serta analisis persepsi penduduk pada area permukiman. Sementara itu, ruang lingkup wilayah penelitian ini adalah area permukiman yang berada di dekat Jalan Tol Jagorawi dan Jalan Pandu, Kelurahan Baranangsiang, Kota Bogor.

\section{Kerangka Pikir Penelitian}

Lanskap perkotaan seringkali mengalami berbagai permasalahan terkait kualitas lingkungan. Kota Bogor merupakan salah satu kota di Indonesia yang kualitas lanskapnya terus menurun yang disebabkan oleh pesatnya pertumbuhan pendiduk dan pembangunan kota. Dalam pembangunan perkotaan, khususnya pada Kawasan perumahan, seringkali menimbulkan berbagai masalah, salah satunya kebisingan. Bising yang ditimbulkan dari kendaraan dan mesin konstruksi dapat menimbulkan dampak negative bagi manusia dan makhluk hidup diseketilingnya. Usaha untuk mengontrol bising dapat dilakukan melalui manipulasi sumber suara, jalur suara, dan penerima suara. Pengendalian kebisingan pada jalur suara dapat dilakukan dengan barrier tanaman dan dinding pengahralang. Bising pada kawasan permukiman seringkali membuat penghuni perumāhan menjadi tidak nyaman, sehingga diperlukan analisis tingkat bising, analisis-efektivitas jalur hijau dalam mengurangi bising, serta analisis persepsi 
dan preferensi penduduk mengenai kenyamanan audial. Dengan demikian, dapat dibuat rekomendasi konsep ruang terbuka hijau pada kawasan perumahan dalam menciptakan kenyamanan audial sehingga dapat membuat lingkungan kawasan perumahan menjadi lebih nyaman. Berikut merupakan bagan kerangka pikir pada penelitian ini (Gambar 1).

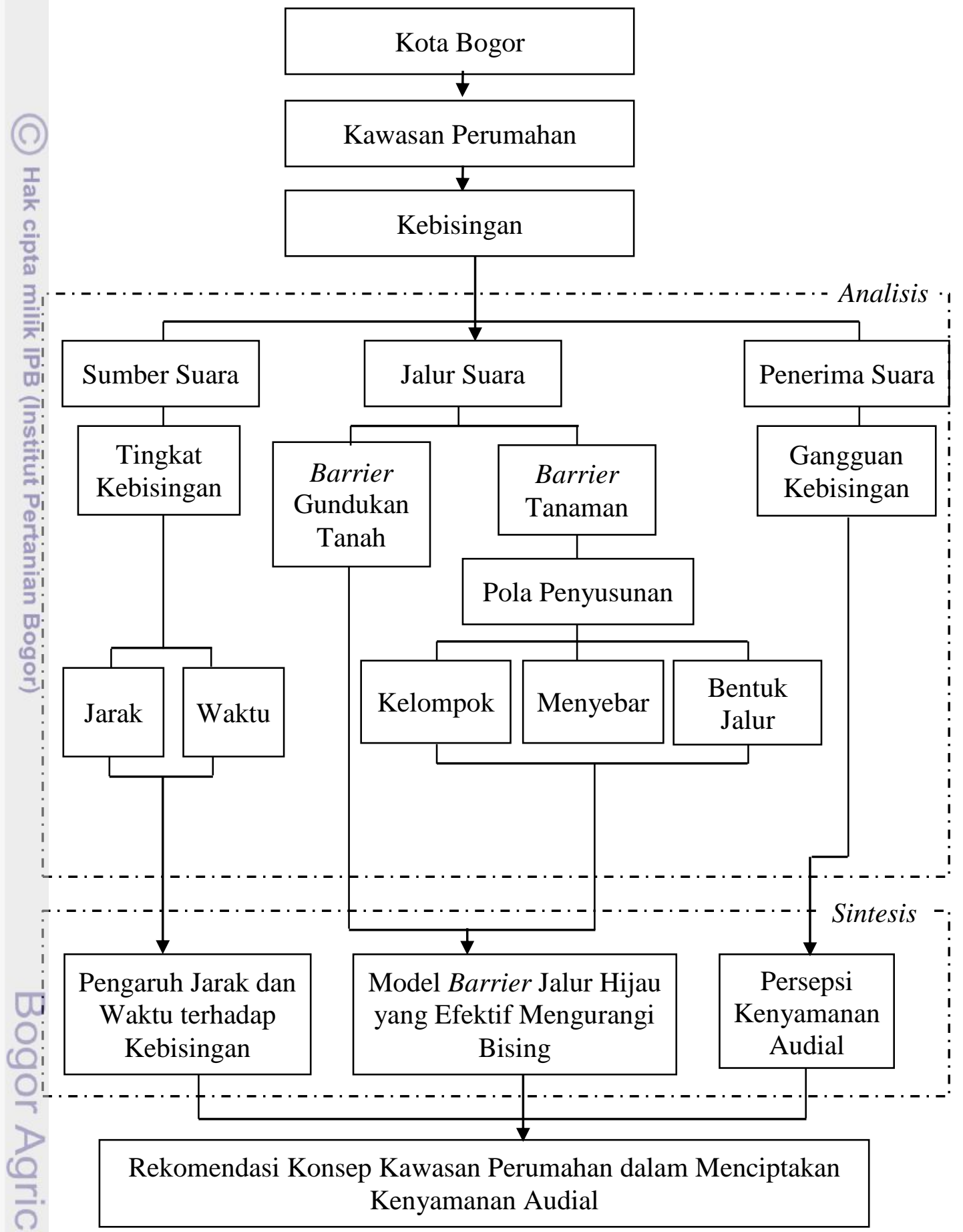

Gambar 1 Bagan kerangka pikir 


\section{TINJAUAN PUSTAKA}

\section{Perumahan Sekitar Jalan Tol}

Perumahan, menurut UU Nomor 1 Tahun 2011 Tentang Perumahan dan Kawasan Permukiman, adalah kumpulan rumah sebagai bagian dari permukiman, baik perkotaan maupun perdesaan, yang dilengkapi dengan prasarana, sarana, dan utilitas umum sebagai hasil upaya pemenuhan rumah yang layak huni. Menurut Tilaar et al (2012), permukiman dapat diklasifikasikan kedalam permukiman terencana dan tidak terencana. Permukiman terencana adalah permukiman dimana pemba⿳⺈ gunannya terencana secara keseluruhan, seperti sarana jalan, drainase, ruang ferbuka, pola tata massa, dan sebagainya, sedangkan untuk permukiman yang tî́lak terencana merupakan permukiman yang dibangun secara bertahap dari unit-uñit oleh masing-masing pemilik dengan kondisi lingkungan yang kurang terencā̄na seperti jalan dan drainase. Menurut Kwanda (2000), konsep perencaan real estate terbagi menjadi tiga, diantaranya pola konvensional, cluster, dan planned unit development (PUD). Sementara itu, terdapat tiga pola jalan dalam perencănaan real estate, yaitu pola kotak (grid), pola putaran (loop), dan pola cul de sac 랄

Pembangunan jalan tanjakan dan jalan tol yang menembus daerah permukiman dan perumahan banyak terdapat pada kota-kota besar akibat tuntutan dari pêtmbangunan infrastruktur jalan dan kemudahan aksesibilitas di dalam kota. Pembäingunan infrastruktur jalan tersebut menimbulkan dampak positif dan negative. Dampak positif dapat meliputi nilai lahan cenderung meningkat, berkembangnya kegiatan komersial, peningkatan aksesibilitas, dan menurunnya tingkae kemacetan. Sementara itu, dampak negative yang ditimbulkan dari pembangunan jalan layang diantaranya timbulnya polusi udara, polusi suara, dan menurunnya estetika lingkungan. Keputusan Menteri Kesehatan Nomor 829/MENKES/SK/VII/1999, menyatakan bahwa persyarakat kesehatan perumahan dan lingkungan permukiman dalam hal kebisingan dan getaran yang dianjurkan adalah 45 - 55 dBA untuk kebisingan dan tingkat getaran maksimum $10 \mathrm{~mm} /$ detik. Menurut data dari Departemen Kesehatan Republik Indonesia (1994) dalam Ikron (2007), tingkat kebisingan lalu lintas jalan pada permukiman di tiga kota, yaitu Kota Bekasi, Bogor, dan Tangerang rata-rata diatas 70 dBA.

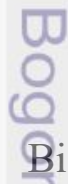

\section{Bising}

Bising didefinisikan sebagai "suara yang tidak diinginkan" dari berbagai jenis dan intensitas, termasuk kebisingan dari transportasi dan industry, dianggap sebagai polutan dan sebagai stressor lingkungan (lingkungan penuh tekanan) yang merupakan ciri menonjol dari lingkungan perkotaan (Lagonigro 2018). Bising dapatmenyebabkan berbagai gangguan terhadap kesehatan, seperti peningkatan tekanan darah, gangguan psikologis, gangguan komunikasi, gangguan keseimbangan, dan gangguan pendengaran (Lintong 2009). Kebisingan pada umumña merupakan bunyi yang terdiri dari sejumlah frekuensi dengan tingkat bunyi-berbeda-beda dalam besaran desibel $(\mathrm{dB})$. 
Pengukuran bising dapat dilakukan dengan menggunakan bantuan orang yang berkompeten dan menggunakan alat sound level meter. Kriteria pengukuran bising dengan menggunakan 'orang yang kompeten', diantaranya (1) memiliki pemahaman yang baik mengenai akustik dan praktik standar pengukuran, (2) memiliki pengetahuan yang lebih detail mengenai standar dan pedoman nasional, (3) terbiasa dalam memantau kebisingan, dan (4) memiliki kemampuan untuk menginterpretasikan hasil yang memerlukan penyelidikan lebih lanjut. Sound level meter merupakan instrument yang merekam tingkat suara serta melakukan analisis tambahan pada suara untuk menyajikan informasi yang dapat digunakan kepada Operator. Alat ini mampu mencatat data secara terus menerus dalam jangka waktu tama, serta beberapa alat ini juga dilengkapi dengan GSM (Global System for Mobile communication) dan dapat dimonitor dari jarak jauh (Murphy dan King z014). Sound level meter harus memenuhi spesifikasi dari IEC 61672-1 (international Electrotechnical Commission). Pada dasarnya, alat ini terdiri dari mikrofon omnidirectional, attenuator yang telah dikalibrasi, jaringan pembobot, ऐenguat arus listrik yang stabil, squarer, sirkuit rata-rata, dan indicator (Peterson 1980). Cara kerja alat ini adalah tekanan suara yang direkam oleh mikrofon omnidirectional akan diubah menjadi tegangan listrik, kemudian melewati pembobotan frekuensi dan waktu, dan menampilkan hasil pengukuran (Maekawa et al 2011).

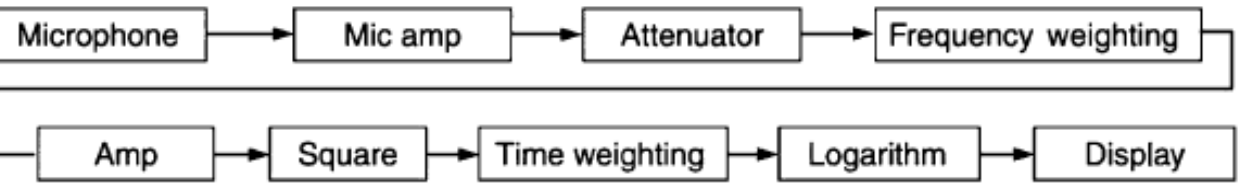

Gambar 2 Diagram blok sound level meter

Menurut Fithri dan Annisa (2015), ditinjau dari hubungan tingkat bunyi sebagai waktu maka kebisingan dibedakan menjadi:

1. kebisingan kontinyu (steady state wide band noise), yaitu bising tidak lebih dari $6 \mathrm{dBA}$ dengan spectrum frekuensi yang luas. Contohnya, bunyi yang ditimbulkan dari mesin gergaji dan katub gas.

2. kebisingan terputus-putus (intermitten noise), merupakan bising dimana bunyi mengeras dan melemah secara perlahan-lahan. Misalnya, bising lalu lintas dan kereta api.

3. kebisingan impulsive berulang (impulse noise), bising yang memekakkan

(0) telinga dalam waktu relative singkat, misalnya suara ledakkan senjata.

(4) steady state noise, merupakan kebisingan yang tingkat tekanan bunyinya stabil

6 terhadap perubahan waktu, misalnya bising di sekitar air terjun.

5. fluctuating noise, merupakan kebisingan yang kontinyu namun berubah-ubah tingkat tekanan bunyinya.

Menurut Keputusan Menteri Lingkungan Hidup Nomor 48 Tahun 1996,

baku mutu tingkat kebisingan dibagi menjadi dua bagian besar, yaitu untuk peruntukan kawasan dan peruntukan lingkungan kegiatan. Artinya, lingkungan kegiatan mungkin saja berada pada peruntukan kawasan yang berbeda, seperti yang terlampir pada Tabel 1. 
Tabel 1 Baku mutu tingkat kebisingan

\begin{tabular}{|c|c|c|c|}
\hline & & Peruntukan Kawasan/Lingkungan Kegiatan & $\begin{array}{c}\text { Tingkat Kebisingan } \\
\mathrm{dB}(\mathrm{A})\end{array}$ \\
\hline \multirow[t]{13}{*}{ A. } & & Peruntukan Kawasan & \\
\hline & 1. & Perumahan dan Permukiman & 55 \\
\hline & 2. & Perdagangan dan Jasa & 70 \\
\hline & 3. & Perkantoran dan Perdagangan & 65 \\
\hline & 4. & Ruang Terbuka Hijau & 50 \\
\hline & (5.) & Industri & 70 \\
\hline & 6. & Pemerintahan dan Fasilitas Umum & 60 \\
\hline & F. & Rekreasi & 70 \\
\hline & 8 & Khusus: & \\
\hline & త & - Bandar Udara* & \\
\hline & $\underline{3}$. & - Stasiun Kereta Api* & \\
\hline & $\overline{\bar{\lambda}}$ & - Pelabuhan Laut & 70 \\
\hline & $\overline{0}$ & - Cagar Budaya & 60 \\
\hline \multirow[t]{4}{*}{ B. } & $\stackrel{\infty}{=}$ & Lingkungan Kegiatan & \\
\hline & $\overline{\overline{\mathrm{B}}}$ & Rumah sakit atau sejenisnya & 55 \\
\hline & 死 & Sekolah atau sejenisnya & 55 \\
\hline & 3. & Tempat ibadah atau sejenisnya & 55 \\
\hline
\end{tabular}

Sumber: Kepmen LH No. 48/MENLH/11/1996

Keterangigan *) disesuaikan dengan ketentuan Menteri Perhubungan

\section{Sumber Bising di Jalan}

Kebisingan yang ditimbulkan oleh kendaraan bermotor berasal dari beberapa sumber, yaitu mesin, transmisi, rem, klakson, knalpot, dan gesekan roda dengan jalan. Kebisingan akibat gesekan roda dengan jalan tergantung pada beberapa factor, seperti jenis ban, kecepatan kendaraan, kondisi permukaan jalan, dan kemiringan jalan. Kecepatan kendaraan mempengaruhi kebisingan yang muncul akibat gesekan ban dengan permukaan jalan. Jalan yang tidak halus dan basah akan menimbulkan tingkat bising yang tinggi (White dan Walker 1982).

Kemiringan jalan dapat mempengaruhi kebisingan. Pada tanjakan jalan, dibutuhkan torsi yang lebih besar dibandingkan saat jalan rata, agar kendaraan dapat bergerak. Untuk menghasilkan torsi yang lebih besar, dibutuhkan perseneling rendah dengan putaran mesin tinggi, sehingga akan menghasilkan kebisingan yang lebih tinggi. Demikian pada saat kendaran menuruni jalan, perseneling rendah dibutuhkan untuk membantu pengereman, agar rem menjadi lebih efektif (White dan Walker 1982). Dari uraian tersebut, dapat disimpulkan bahwa kebisingan pada area bangunan yang berada di tepi jalan tanjakan akan lebih inggi dibandingkan dengan area bangunan yang berada di tepi jalan datar dengan permukaan halus. 


\section{Analisis Frekuensi}

Analisis frekuensi atau analisis spektrum juga dibutuhkan dalam pengukuran tingkat bising. Dalam analisis frekuensi terdapat berbagai pita frekuensi, salah satunya pita oktaf. Analisis ini menghasilkan serangkaian level, satu untuk setiap band, yang disebut juga 'level band' atau 'band oktaf'. Dalam pengukuran bising, analisis frekuensi yang biasa dilakukan, diantaranya analisis frekuensi 1/1 oktaf (octave band analysis) dan analisis frekuensi 1/3 oktaf (onethird octave band analysis). Analisis $1 / 1$ oktaf memiliki lebar pita sebesar satu oktaf dengan rentang sepuluh pita, yaitu $31.5 \mathrm{~Hz}, 63 \mathrm{~Hz}, 125 \mathrm{~Hz}, 250 \mathrm{~Hz}, 500 \mathrm{~Hz}$, $1000 \mathrm{~Hz}, 2000 \mathrm{~Hz}, 4000 \mathrm{~Hz}, 8000 \mathrm{~Hz}$, dan $16000 \mathrm{~Hz}$ (Peterson 1980).

Analisis frekuensi $1 / 3$ oktaf biasanya digunakan untuk menganalisis frekuensi bising yang lebih rinci. Analisis 1/3 oktaf memiliki lebar pita sebesar sepertiga oktaf, dengan rentang pita yang lebih banyak, misalnya $100 \mathrm{~Hz}, 125 \mathrm{~Hz}$, E $60 \mathrm{~Hz}, 200 \mathrm{~Hz}, 250 \mathrm{~Hz}, 315 \mathrm{~Hz}, 400 \mathrm{~Hz}, 500 \mathrm{~Hz}, 630 \mathrm{~Hz}, 800 \mathrm{~Hz}, 1000 \mathrm{~Hz}$, $\overline{2} 50 \mathrm{~Hz}, 1600 \mathrm{~Hz}, 2000 \mathrm{~Hz}, 2500 \mathrm{~Hz}$, dan seterusnya (Peterson 1980). Analisis frekuensi 1/1 oktaf merupakan bagian dari analisis 1/3 oktaf, karena frekuensi pita \#1 oktaf terdapat juga pada pita 1/3 oktaf (Wilson 1994).

\section{Dampak Kebisingan}

Kebisingan dapat menyebabkan kerusakan pendengaran, namun dampak tersebut akan terjadi secara bertahap dan jika berlangsung secara terus menerus akan menyebabkan kerusakan pendengaran yang permanen (Peterson 1980). Manusia memiliki kemampuan mendengar frekuensi suara mulai $20 \mathrm{~Hz}$ hingga $20000 \mathrm{~Hz}$. Manusia dapat mendengar suara hingga $140 \mathrm{~dB}$, namun bila lebih dari $140 \mathrm{~dB}$ mengakibatkan kerusakan pada gendang telinga. Ambang batas maksimum yang aman bagi telinga manusia adalah 80 dB (Lintong 2009). Ketika telinga sering terpapar dengan tingkat kebisingan yang lebih tinggi akan menyebabkan sel-sel rambut koklea distimulasi terus-menerus dan dapat menyebabkan kematian dari fungsi sel-sel rambut koklea. Ini biasanya terjadi pada rentang $2000-4000 \mathrm{~Hz}$, dimana mekanisme pendengaran memiliki sensitivitas terbesar, seperti suara dengung pada telinga atau dengan kata lain disebut tinnitus (Cowan 1994). Selain pendengaran, kebisingan juga memiliki dampak lain bagi manusia, diantaranya gangguan kenyamanan dan stress pada anak-anak, gangguan konsentrasi, dan menurunnya kualitas kerja (Goembira et al 2003; Hernawan 2008 dalam Anangga et al 2015).

Menurut Anangga et al (2015), terdapat tiga gangguan akibat dari Kebisingan, yaitu gangguan psikologis, gangguan fisiologis, dan gangguan komunikasi. Gangguan psikologis merupakan gangguan dimana kondisi psikis yang dimiliki oleh komunikan dan komunikator. Gangguan psikologis dapat berupa kurang konsentrasi, rasa tidak nyaman, susah tidur, dan cepat marah. Bila berlangsung dalam waktu lama, dapat menyebabkan penyakit psikosomatik, seperti stress, kelelahan, jantung, dan gastritis. Gangguan komunikasi merupakan gangguan yangm ditandai dengan kesulitan dalam pemahaman atau penggunaan bahasa. Biasanya pendengaran menjadi kurang jelas atau gangguan kejelasan strara. Gangguan fisiologis merupakan gangguan yang mengakibatkan fungsi 
pendengaran secara fisiologis terganggu, seperti meningkatnya tekanan darah, peningkatan denyut nadi, kontraksi pembuluh darah perifer, pucat, dan gangguan sensoris. Adapun menurut Cowan (1994), gangguan fisiologis lainnya adalah tinnitus. Tinnitus umumnya disebabkan oleh stimulasi berlebihan pada saraf pendengaran. Ketika terpapar oleh kebisingan tingkat tinggi, tinnitus dapat berlangsung selama beberapa menit hingga hari, namun biasanya mereda dalam beberapa jam. Jika tinnitus tidak mereda setelah beberapa hari, maka disarankan untuk melakukan konsultasi medis.

\section{Pengendalian Bising}

Rebisingan dapat menimbulkan gangguan bila tidak ditangani dengan baik. Oleh kârena itu, perlu dibuat usaha untuk mengontrol kebisingan hingga mencapai tingka . atau level yang dapat diterima oleh telinga manusia. Upaya pengendalian

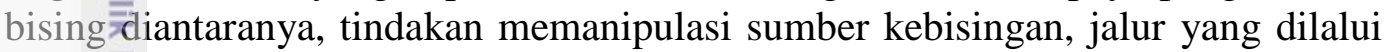

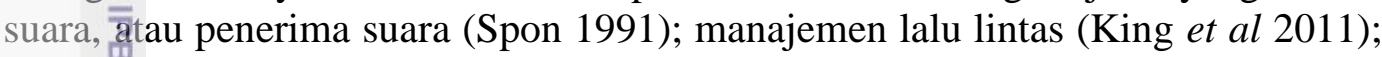
pendekatan soundscape (Papadimitrou et al 2009); dan insulasi fasad bangunan (Taherzadeh 2014). Menurut Bachtiar et al (2013), upaya pengendalian bising dapat dilakukan dengan menggunakan barrier. Barrier dapat berupa dinding massif pagar, gundukan tanah, tanaman pagar, dan bangunan lain yang ditempatkan diantara sumber suara dan penerima (Wilson 1994). Menurut Jiang dan Kang (2016), Barrier yang yang lebih tinggi lebih efektif mengurangi kebisin̈gan dibandingkan dengan barrier yang lebih rendah.

Dinding berbentuk benteng dan dinding yang dibentuk berkelok-kelok sangato baik untuk menciptakan visual pandangan yang lebih menarik dan memberikan tempat bagi tanaman. Kedua jenis dinding tersebut memiliki keuntungan struktur konstruksi yang lebih kuat dan tahan roboh yang menjadi persyaratan bagi dinding penghalang kebisingan. Karakteristik material dinding penghalang peredam bising dipengaruhi oleh lokasi, panjang dan tinggi dinding, sifat transmitif (daya hantar), reflektif (daya pantul) atau absorptive (daya serap) dari material penyusunnya. Beberapa jenis material dinding penghalang yang dapat digunakan sebagai peredam bising, diantaranya kayu, panel beton pracetak, beton ringan berongga (aerated), panel fiber semen, panel acrylic transparan dan baja profil (Balitbang PU 2005). Agar dinding penghalang dapat bekerja dengan baik, maka dinding penghalang harus cukup tinggi dan panjang untuk mengurangi bisingke pendengar. Misalnya, untuk bangunan rumah yang berada di permukaan yang Tebih rendah dari permukaan jalan maka dinding penghalang perlu dibangun lebih inggi. Jika letak bangunan rumah konstan, maka dinding penghalang dapat diletakkan dekat dengan sumber maupun pendengar agar kemampuan redamannya meningkat.

(E)fektifitas bangunan dalam mengurangi kebisingan sangat dipengaruhi oleh bahan dan dimensi bangunan. Menurut uji laboratorium Balitbang PU (2005), bahan yang terbuat dari susunan batu bata dengan lebar $0.5 \mathrm{~m}$ dan tinggi $2.5 \mathrm{~m}$ memiliki IL (insertion loss) sebesar $15-16 \mathrm{~dB}(\mathrm{~A})$, kemudian bahan kayu yang memiliki lebar $0.3 \mathrm{~m}$ dan tinggi $2-3 \mathrm{~m}$ memiliki IL $18-19 \mathrm{~dB}(\mathrm{~A})$, selain itu bahan fiber dan kaca dengan lebar $0.5 \mathrm{~m}$ dan tinggi $3-4 \mathrm{~m}$ memiliki IL $16-17$ $\mathrm{dB}(\mathrm{A})$. Ketinggian dinding penghalang yang lebih rendah daripada dinding 
bangunan memerlukan perhitungan yang tepat untuk mendapatkan reduksi suara yang efektif (Mashuri 2007). Salah satu metode untuk menghitung keefektifan dinding penghalang adalah menggunakan persamaan berikut (Taherzadeh 2014).

$$
\overline{\mathrm{A}}=10 \log \left(3 \pm \frac{20}{N}\right)
$$

dimana:

$\overline{\mathrm{A}}$ : atenuasi barrier $(\mathrm{dB})$

N: Fresnel Number $\left(\frac{2 \delta}{\lambda}\right)$

\&: $(\mathrm{A}+\mathrm{B})-\mathrm{C}$, perbedaan jalur suara (Gambar 3)

A: jarak dari sumber suara ke puncak barrier (m)

B: jarak dari puncak barrier ke penerima $(\mathrm{m})$

e: jarak dari sumber suara ke penerima $(\mathrm{m})$

t: panjang gelombang suara $(\mathrm{m})$

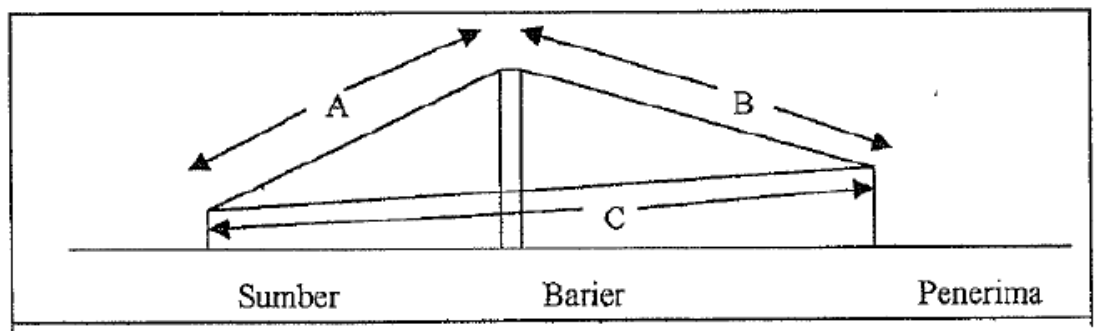

Ğambar 3 Jalur suara yang digunkaan untuk menghitung perbedaan jalur س $\quad$ Sumber: Taherzadeh (2014)

Dengan demikian, perbedaan jalur suara tergantung pada ketinggian sumber suara, penerima dan penghalang, serta jarak sumber dan penerima dari penghalang. Persamaan diatas didasarkan pada teori difraksi dengan asumsi transmisi suara melalui dinding penghalang diabaikan. Dalam praktiknya, insulasi suara yang dihasilkan oleh material dinding penghalang harus memadai untuk memastikan bahwa tingkat suara yang ditransmisikan setidaknya $10 \mathrm{~dB}$. Jika barrier $(\overline{\mathrm{A}})$ bernilai positif, maka menunjukkan barrier memotong jalur transmisi suara dari sumber suara ke penerima, sebaliknya jika barrier $(\overline{\mathrm{A}})$ bernilai negative maka jalur suara antara sumber suara dengan penerima tidak terpotong oleh barrier (Taherzadeh 2014). Grafik koreksi potensial barrier sebagai fungsi dari perbedaan jalur dapat ditunjukkan pada Gambar 4.

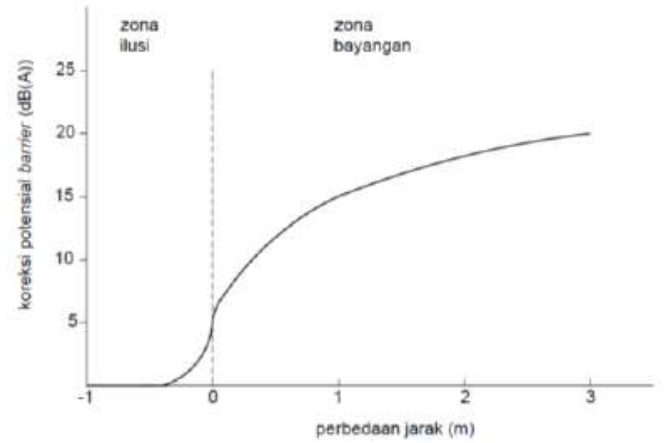

Gambar 4 Grafik koreksi potensial barrier

Sumber: Taherzadeh (2014) 
Gundukan tanah dapat dikatakan sebagai jenis penghalang suara kebisingan paling alami. Kombinasi gundukan tanah dan dinding sangat efektif untuk mengendalikan suara kebisingan, terutama bila gundukan tanah tidak mencapai persyaratan ketinggian untuk mengurangi kebisingan (Hakim 2006).

Pada ruang perkotaan, tidak semua dapat menggunakan dinding penghalang yang tinggi karena keterbatasan ruang, keamanan, dan dampak visual. Salah satu solusi untuk mengganti dinding penghalang namun tetap memberikan fungsi yang sama dalam mengendalikan bising adalah menggunakan barrier tanaman.

Barrier tanaman dapat digunakan sebagai penghalang untuk mereduksi kebisingan, karena dapat menyerap dan memancarkan energy bunyi (Marsh 1986). Pada jalan, tanaman biasanya dalam bentuk sabuk hijau (tree belts). Selain dapat mengữangi bising, manfaat pohon-pohon di jalan, yaitu dapat melindungi pejalan kaki fari matahari dan hujan; sebagai habitat dan konektivitas satwa, seperti burung, tupai; serta dapat menurunkan suhu di perkotaan dan mengurangi limpasan air hujan (Onder et al 2012). Jenis tanaman yang digunakan untuk penghẩang kebisingan harus memiliki kerimbunan dan kerapatan daun yang cukup dan merata, mulai dari permukaan tanah hingga ketinggian yang diharapkan. Untuk itu perlu diatur suatu kombinasi antara tanaman penutup tanah, perdu,, pohon, dan bahan lainnya sehingga efek barrier menjadi optimum (Balitbǟng PU 2005).

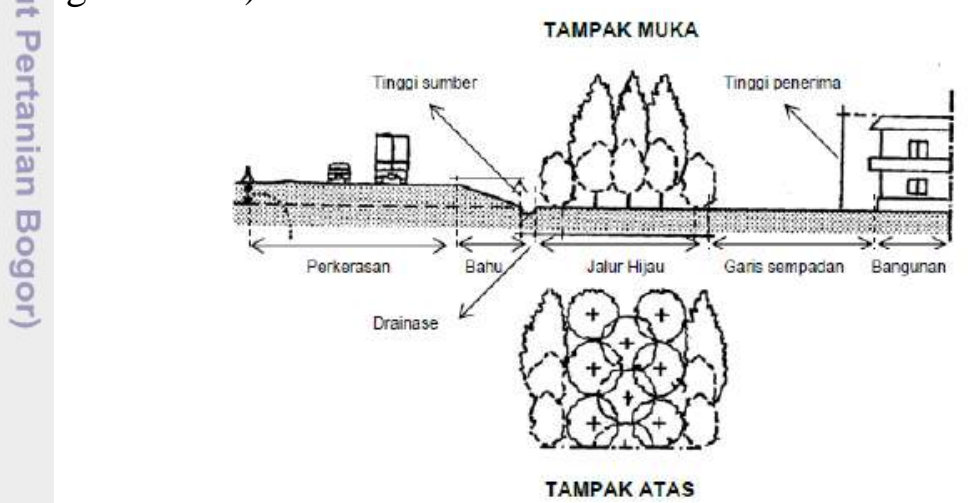

Gambar 5 Tanaman dikombinasi dengan tanaman lain untuk memperbesar kerimbunan

Sumber: Balitbang PU (2005)

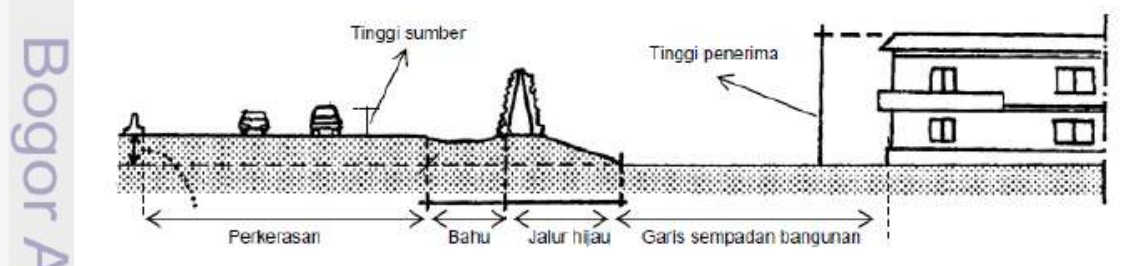

Gambar 6 Tanaman dikombinasi dengan gundukan tanah dan dinding Sumber: Balitbang PU (2005)

Kombinasi antara vegetasi dan dinding, atau dikenal dengan istilah green barrier, juga dapat dijadikan alternative pada lahan yang sempit (Van Renterghem et al 2015). Dinding dan semak padat dapat dianggap sebagai penghalang kebisingan yang efektif, jika tingginya lebih besar daripada posisi penerima. 
Penelitian yang dilakukan oleh Kalansuriya et al (2009) mengenai pengaruh vegetasi di pinggir jalan dalam mengurangi kebisingan adalah $4 \mathrm{~dB}$, namun jika tebal vegetasi menjadi $1.5 \mathrm{~m}$ maka dapat mengurangi $5 \mathrm{~dB}$. Menurut Carpenter et al (1975), tanaman dengan lebar $6-15 \mathrm{~m}$ dapat mereduksi hingga $10-20 \mathrm{~dB}$ pada frekuensi tinggi. Tanaman dan dinding mampu mereduksi suara dalam rentang frekuensi yang rendah maupun tinggi. Dinding penghalang dapat mereduksi suara yang berada dalam frekuensi $500 \mathrm{~Hz}-5000 \mathrm{~Hz}$, sedangkan tanaman memiliki kemampuan mereduksi bising dengan frekuensi berbeda, misalnya bamboo cina (Chimonobambusa quadrangularis), akalipa (Acalypha Wilkenasia), dan bambu (Bambusa vulgaris) dapat mereduksi frekuensi $500 \mathrm{~Hz}-$ $5000 \mathrm{~Hz}$ dan soka dapat mereduksi bising diatas $100 \mathrm{~Hz}$ (Widagdo 1998).

\section{Karakteristik Tanaman Pereduksi Bising}

Tanaman yang efektif dalam mereduksi kebisingan adalah yang memiliki đạun lebat sepanjang tahun dengan pola daun menyebar hingga ke permukaan tanah (Carpenter et al 1975), sementara menurut Fakuara (1986) tanaman yang pảing efektif meredam suara ialah yang mempunyai lapisan tajuk yang tebal, däun yang ringan, dan bertangkai daun. Tingkat kebisingan yang dapat direduksi G̈ teh tanaman juga bergantung pada kepadatan tanaman, tinggi tanaman, dan lebar penanaman. Penanaman beberapa spesies secara bersama lebih efektif dalam mereduksi kebisingan daripada penanaman tunggal. Faktor lingkungan yang ikut miempengaruhi tingkat penerimaan kebisingan adalah arah angin, suhu, dan kelembaban. Selain itu, tingkat kebisingan yang dapat direduksi oleh tanaman juga dipengaruhi oleh intensitas, frekuensi, dan arah suara. Frekuensi yang dapat đireduksi dengan baik oleh masing-masing tanaman berbeda-beda, tetapi sebagian besar tanaman dapat mereduksi bising pada frekuensi tinggi (Carpenter et al 1975). Penyerapan kebisingan oleh tanaman lebih efektif terjadi pada suara dengan frekuensi tinggi $1000-2000 \mathrm{~Hz}$ (Marsh 1986). Menurut Onder dan Kocbeker (2012), prinsip-prinsip yang diperlukan untuk membangun green belts dalam mengurangi kebisingan adalah sebagai berikut.

a. lebar tanam adalah $5 \mathrm{~m}-30 \mathrm{~m}$;

b. tanaman yang digunakan dipilih dari flora lokal atau varietas yang sesuai;

c. tanaman utama harus memiliki daun jarum;

d. tanaman harus ditanam sedekat mungkin antara satu sama lain dan jarak antara

0 dua tanaman harus sesuai dengan kondisi pertumbuhannya;

e. kriteria tanaman yang dapaat digunakan adalah tinggi, besar, bertekstur keras, dan bercabang;

menggunakan kombinasi ketinggian tanaman, seperti pohon, semak, dan groundcover;

g. tanaman yang lebih tinggi ditanam di sisi bagian belakang dari tanaman yang lebih pendek. Tanaman semak, termasuk jenis konifera, yang ditanam lebih dari $5 \mathrm{~m}$ dapat memblokir kebisingan;

7.-akan lebih baik apabila green belts ditempatkan sedekat mungkin dengan sumber kebisingan; serta 
i. akan lebih efisien apabila penempatan green belts dikombinasikan dengan dinding penghalang kebisingan dan gundukan tanah untuk mengurangi kebisingan.

Menurut Fang dan Ling (2003), semak paling efektif dalam mengurangi kebisingan karena memiliki dedaunan yang lebat dan ranting-ranting yang banyak, sementara pohon memiliki dedauanan dan ranting yang lebih sedikit. Pohon dengan tinggi yang cukup dapat menyerap bising, oleh karena itu, kombinasi antara semak dan pohon dapat dimanfaatkan, artinya, semak harus ditanam dibawah pohon, sehingga memungkinkan tree belts mereduksi kebisingan dengan baik. Jenis tanaman yang efektif dalam menurunkan kebisingan, diantaranya Berberus thujnbergii dan Euonymus japonica dapat menurunkan bising 6.3 dBA; Cotonēaster dammerii dan Pyracantha coccinea dapat menurunkan bising 5.5 dBA; ₹erta Juniperus horizontalis dan Spiraea vanhouetti dapat menurunkan bising 0.2 dBA (Onder dan Kocbeker 2012). Menurut Pudjowati et al (2013), vegetas asam londo (Pithecellobium dulce) dapat mengurangi kebisingan $3.82 \%$ 10.12\%. Hal ini dikarenakan asam londo memiliki daun yang lebat dan bentuk kanopi yang menjuntai hingga ke permukaan tanah. Tanaman yang efektif mengurangi kebisingan adalah daun yang lebat sepanjangn tahun dan pola daun menyebar hingga ke permukaan tanah. Indikasi efektivitas tanaman yang dapat diguna pada Tabel 2.

Tabel 2 Efektifitas pengurangan kebisingan oleh berbagai macam tanaman

\begin{tabular}{|c|c|c|c|c|}
\hline $\begin{array}{l}\text { Jenis Tanaman } \\
\text { Jen } \\
0 \\
0\end{array}$ & $\begin{array}{c}\text { Volume } \\
\text { Kerimbunan } \\
\text { Daun (m3) }\end{array}$ & $\begin{array}{c}\text { Jarak } \\
\text { Sumber ke } \\
\text { Tanaman } \\
(\mathrm{d})(\mathrm{m}) \\
\end{array}$ & $\begin{array}{c}\text { Ketinggian } \\
\text { Pengukuran (m) }\end{array}$ & $\begin{array}{l}\text { Rata-rata } \\
\text { Reduksi } \\
\text { Kebisingan } \\
\text { IL (dBA) } \\
\end{array}$ \\
\hline Akasia & 114.39 & 18.20 & 1.20 & 2.5 \\
\hline \multirow[t]{3}{*}{ (Acacia mangium) } & & 30.20 & 4.00 & 4.1 \\
\hline & 118.23 & 18.20 & 1.20 & 2.7 \\
\hline & & 24.60 & 4.00 & 4.4 \\
\hline Bambu pringgodani & 122.03 & 7.0 & 1.20 & 1.1 \\
\hline \multirow[t]{2}{*}{ (Bambuga sp) } & & 16.40 & 2.50 & 4.9 \\
\hline & 366.08 & 35.4 & 1.20 & 14.7 \\
\hline Johar & 60.74 & 9.8 & 1.20 & 0.3 \\
\hline \multirow[t]{2}{*}{ (Casia siamea) } & & 17.0 & 3.60 & 3.2 \\
\hline & 83.24 & 9.6 & 1.20 & 0.20 \\
\hline $\begin{array}{l}\text { Lee Kwan Yew (Venemia } \\
\text { obtusifelia) }\end{array}$ & 2.464 & 8.20 & 1.20 & 2.3 \\
\hline $\begin{array}{l}\text { Sinyonakal } \\
\text { (Durant repens) }\end{array}$ & 1.680 & 9.80 & 1.20 & 0.8 \\
\hline Soka (Jxora sp) & 1.350 & 11.20 & 1.20 & 0.9 \\
\hline Kekaretan & 1.105 & 4.60 & 1.20 & 0.9 \\
\hline Sebe $\bar{z}$. & 1.792 & 3.2 & 1.20 & 3.4 \\
\hline Teh-tehan & 13.88 & 6 & 1.20 & 2.7 \\
\hline$\subseteq$ & 2.75 & 9 & 1.20 & 3.8 \\
\hline Heliconita sp & 16.65 & 6 & 1.20 & 4.2 \\
\hline$=$ & 33.3 & 9 & 1.20 & 5.0 \\
\hline
\end{tabular}

Sumber. Balitbang PU (2005)

Ket: $\mathrm{d}=$ jarak dari tepi perkerasan sampai dengan penghalang (kelompok tanaman) 


\section{METODOLOGI}

\section{Waktu dan Lokasi Penelitian}

Penelitian dilakukan pada bulan Maret-April 2019 di perumahan IPB 1 Baranangsiang yang terletak di Kelurahan Baranangsiang, Kecamatan Bogor Timur, Kota Bogor (Gambar 7). Dalam penelitian ini, pola Perumahan IPB 1 Baranangsiang merupakan pola konvensional, dimana tingkat kepadatan rumah memiliki batas kapling yang jelas dan bentuk kapling relative sama tersebar secara merata pada seluruh lahan, perumahan tersebut pola jalan berbentuk grid. Pola 嵝lan grid adalah pola jalan paling efisien untuk mendapatkan jumlah rumah secara maksimal, namun menimbulkan volume lalu lintas yang relative tinggi karena merupakan jalan tembus (Triyuly dan Amelia 2014).

3. Penelitian simulasi juga dilakukan di Laboratorium Kebisingan dan Getaran, E⿱乛龰usat Penelitian dan Pengembangan Kualitas dan Laboratorium Lingkungan (P3KLL), Kawasan Pusat Penelitian Ilmu Pengetahuan dan Teknologi (PUSPIPTEK), Serpong, Tangerang Selatan. Pengukuran akan dilakukan di dalam ang semi bebas gema (hemi anechoic room).

Pada penelitian utama, sumber bising berasal dari Jalan Tol Jagorawi dan Jầlan Padi untuk di sebelah utara, serta Jalan Pandu Raya dan Jalan Sinangling Padi Ramp untuk di sebelah timur. Selain itu, sumber bising pada penelitian șimulasi menggunakan generator suara (speaker).

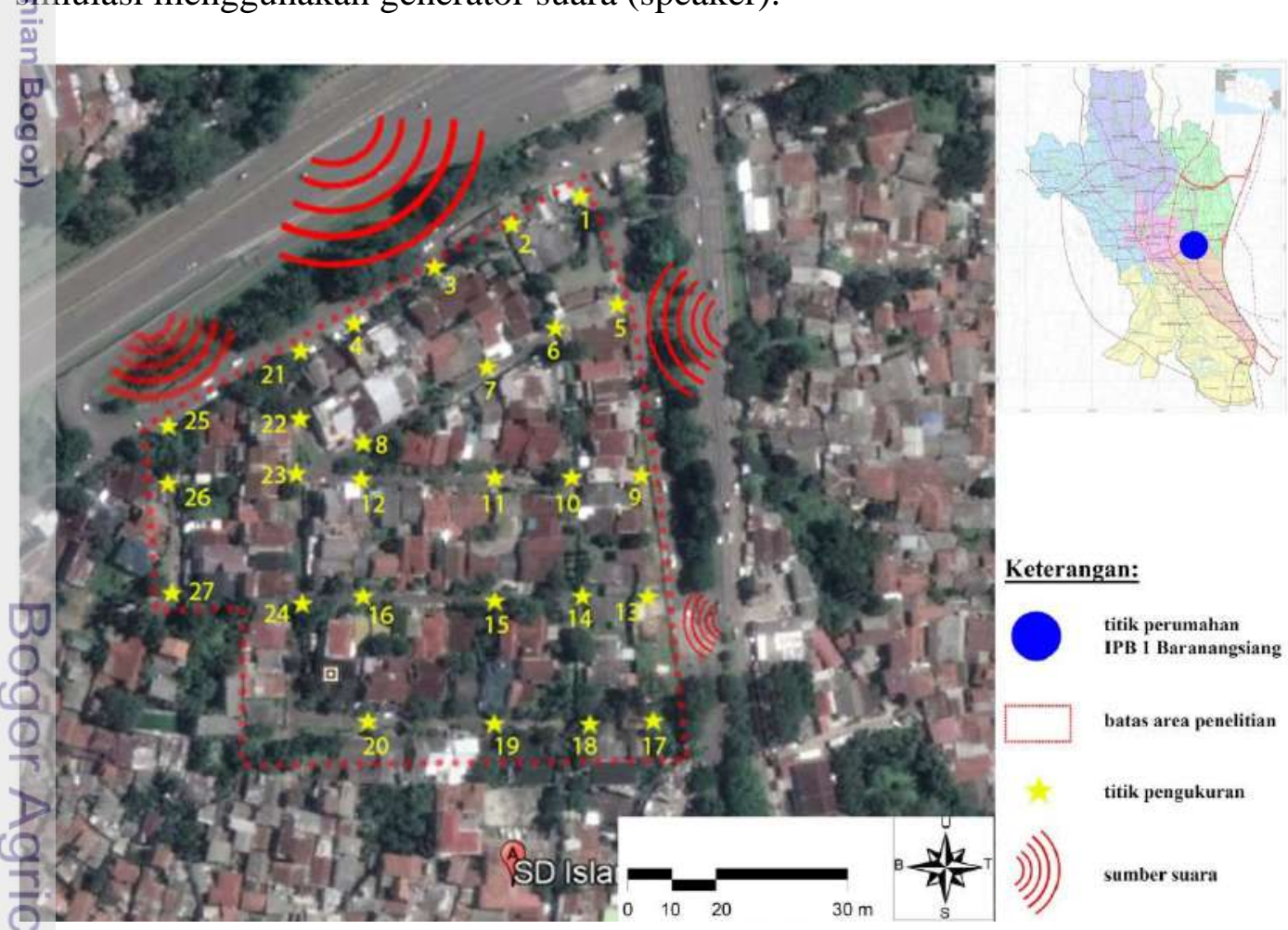

Gambar 7 Lokasi penelitian 


\section{Alat dan Bahan Penelitian}

Pengukuran kebisingan dan faktor-faktor yang mempengaruhinya membutuhkan beberapa alat dan bahan. Alat dan bahan yang digunakan dalam penelitian tersaji pada Tabel 3.

Tabel 3 Alat dan bahan penelitian

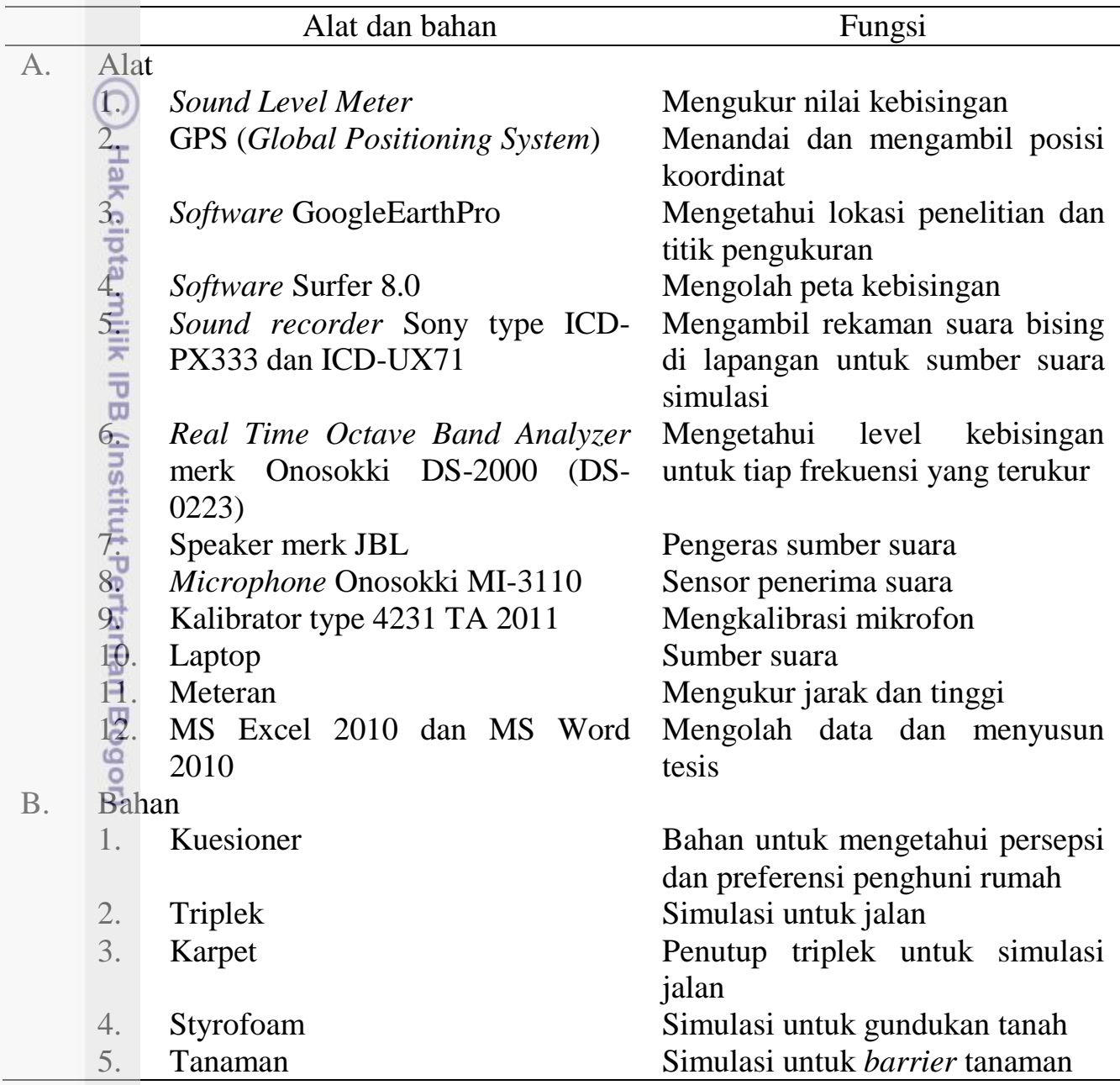

\section{Rancangan Penelitian}

Sebaran bising

Untuk mengukur dan menganalisis sebaran bising di kawasan perumahan, maka bising diukur pada titik $0 \mathrm{~m}$ (sebagai kontrol), $10 \mathrm{~m}, 25 \mathrm{~m}$, dan $50 \mathrm{~m}$ dari sumber bising pada 4 transek yang mengarah pada Jalan Pandu dan 2 transek yang mengarah Jalan Tol Jagorawi, sehingga tiitk pengukuran berjumlah 27 titik. Ilustrasil pengukuran bising ditunjukkan pada Gambar 8 .

Pengukuran bising diukur dengan menggunakan alat Sound Level Meter (SLM) dengan mengukur tingkat tekanan bunyi $\mathrm{dB}(\mathrm{A})$ selama 10 menit dan pembaçaan data dilakukan setiap 5 detik. Ketinggian mikrofon Sound Level Meter adala $1.2 \mathrm{~m}$ (setinggi dada). Waktu pengukuran bising dilakukan selama 16 jam, 
yaitu pukul 06.00 - 22.00 WIB. Pengukuran bising dilakukan sebanyak tiga kali ulangan yang terdiri dari satu hari libur dan dua hari kerja.

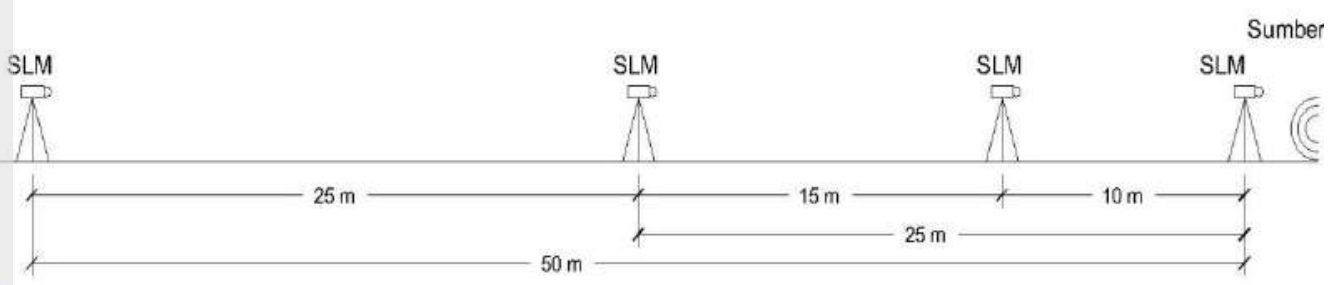

Gambar 8 Ilustrasi pengukuran bising

\section{罴engambilan sampel responden}

Pengambilan sampel dilakukan dengan metode purposive sampling, yaitu Mmenentukan sampel yang akan diambil oleh peneliti berdasarkan tujuan penelitian. Humlah sampel yang diambil sebanyak 30 responden berdasarkan jarak rumah yang sesuai dengan titik pengukuran kebisingan, yaitu rumah pada jarak 0 meter, झ meter, 25 meter, dan 50 meter dari sumber bising. Hal ini bertujuan untuk mengetahui persepsi dan preferensi penghuni rumah mengenai pengaruh kebisingan di lingkungan mereka. Persepsi penduduk terhadap gangguan kebisingan dan kenyamanan audial di lingkungan perumahan dikaji menggunakan skala likert, dengan menggunakan indikator variable sangat setuju (5), setuju (4), ragu-ragu (3), tidak setuju (2), dan sangat tidak setuju (1).

\section{Simulasi pengukuran efektivitas barrier}

Rancangan penelitian simulasi yang dilakukan adalah penentuan model Earrier gundukan tanah dan tanaman. Model tersebut menggunakan skala 1:10, yang artinya dinding penghalang dan tanaman yang digunakan memiliki ukuran 10 kali lebih kecil dibandingkan dengan di lapangan. Jika diasumsikan tinggi gundukan tanah di lapangan adalah $0.6 \mathrm{~m}$, maka ukuran yang digunakan di laboratorium adalah tinggi $0.06 \mathrm{~m}$. Begitu juga dengan tanaman, jika tinggi tanaman di lapang adalah $7.5 \mathrm{~m}$ dan tebal tanaman $2 \mathrm{~m}$, maka ukuran yang digunakan di laboratorium adalah tinggi tanaman $0.75 \mathrm{~m}$ dan tebal tanaman $0.2 \mathrm{~m}$.

Karakteristik penghalang (barrier) yang diamati adalah:

a. tipe barrier (gundukan tanah dan tanaman),

b. pola penyusunan barrier tanaman (bergerombol, menyebar, dan berbentuk jalur), serta

e. tipe tanaman.

דipe tanaman yang digunakan dipilih berdasarkan ketinggian tanaman, yaitu (pohon dan semak dengan tipe daun sedang. Dalam membuat simulasi Taboratorium di dalam ruang semi gema terdapat keterbatasan ruang dalam penyesuaian kondisi lapang. Ukuran panjang jalan di lapangan kurang lebih mencapai $56.5 \mathrm{~m}$, sedangkan ruang semi bebas gema memiliki ukuran panjang 3 $\mathrm{m}$ dan lebar $4 \mathrm{~m}$. Oleh karena itu, pada penelitian simulasi ini dibagi menjadi 2 ftrame. 


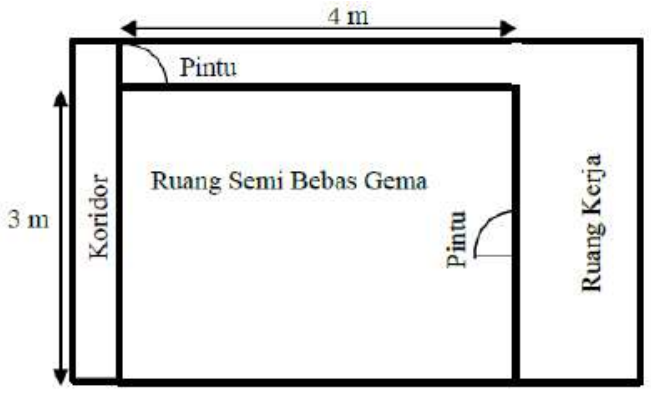

Gambar 9 Denah ruang bebas semi bebas gema

B̄alam satu frame terdapat dua sumber suara yang terletak pada level keting ğian yang berbeda. Sumber suara pertama berada pada level ketinggian yang tébih tinggi daripada sumber suara kedua dan posisi barrier, sedangkan sumber suara kedua berada pada level ketinggian yang sama dengan posisi barrier. Perbedaan kedua frame terletak pada level ketinggian sumber suara pertama, lebar jalan $\overline{\overline{\hat{S}}}$ umber suara kedua, dan lebar penempatan barrier. Ilustrasi frame keadaan/kondisi lapang pada penelitian simulasi ditunjukkan pada Gambar 10.
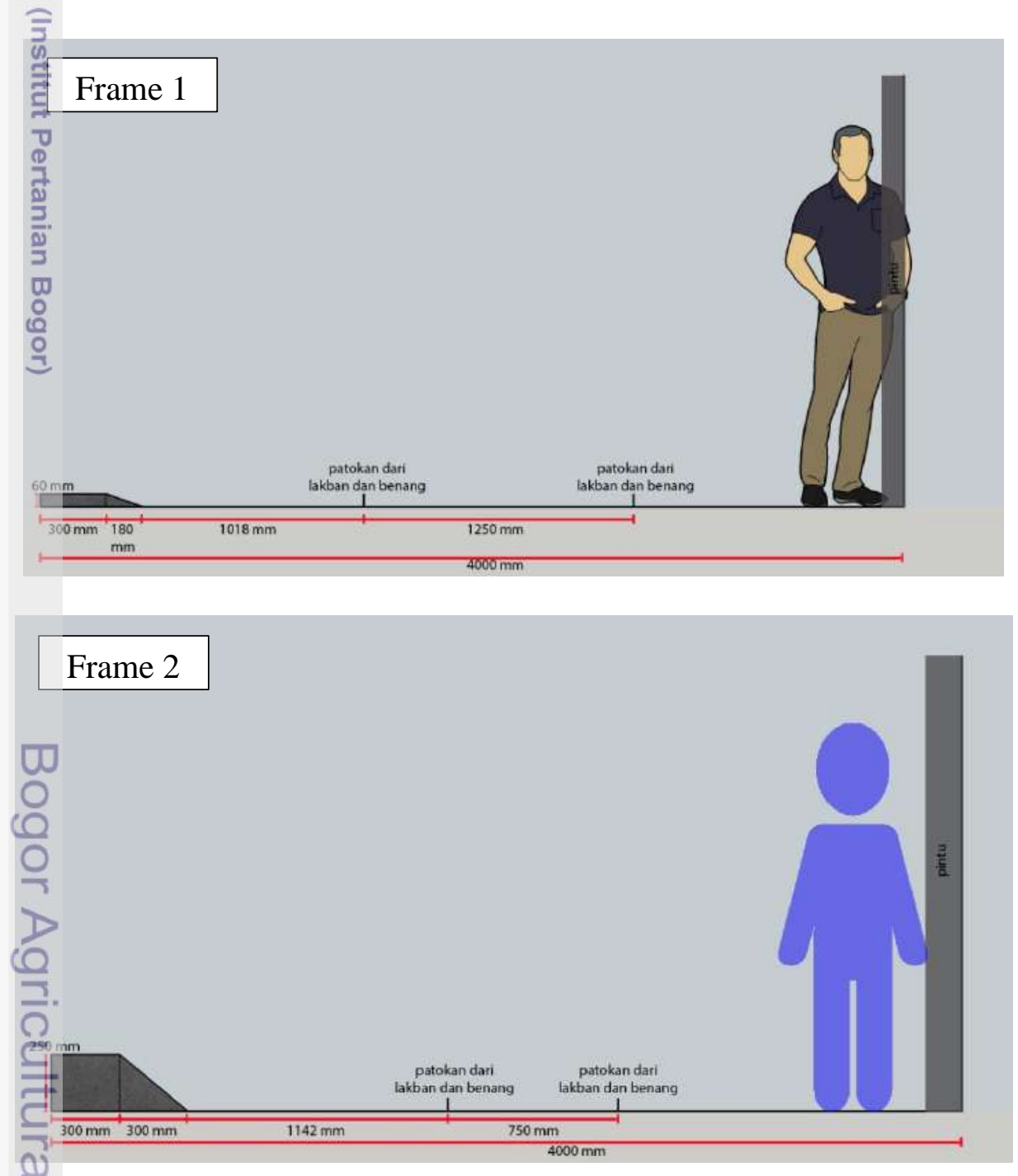

Gambar 10 Ilustrasi keadaan/kondisi lapang di dalam ruang semi bebas gema 
Pada frame 1, terlihat bahwa level ketinggian sumber suara pertama berada pada ketinggian $0.06 \mathrm{~m}$ lebih tinggi dibandingkan dengan sumber suara kedua. Lebar jalan untuk sumber suara kedua adalah $1.018 \mathrm{~m}$ dan lebar penempatan barrier adalah $1.250 \mathrm{~m}$. Kemudian untuk frame 2, level ketinggian sumber suara pertama berada pada ketinggian $0.25 \mathrm{~m}$ lebih tinggi dibandingkan dengan sumber suara kedua. Lebar jalan untuk sumber suara kedua adalah $1.142 \mathrm{~m}$ dan lebar penempatan barrier adalah $0.75 \mathrm{~m}$.

Dari deskripsi kedua frame diatas dapat diketahui bahwa sumber suara pertama pada frame 2 lebih tinggi dibandingkan dengan sumber suara pertama pada frame 1. Lebar jalan untuk sumber suara kedua pada frame 1 memiliki lebar jălan yang lebih kecil dibandingkan dengan lebar jalan pada frame 2. Sumber suara kedua memiliki pengaruh bising lebih besar dibandingkan sumber suara pertama karena adanya pengaruh propagasi suara dari sumber suara pertama. Kemudian untuk lebar barrier pada frame 1 lebih besar dibandingkan dengan E् bar barrier pada frame 2. Oleh karena itu, dapat diketahui bahwa jarak sumber süara menuju penerima pada frame 1 lebih besar dibandingkan dengan frame 2 .

ত Pada simulasi pengukuran terdapat tiga jenis model penyusunan tanaman, antara lain:

a. penyusunan tanaman bergerombol/berkelompok,

E. penyusunan tanaman menyebar, dan

e. penyusunan tanaman berbentuk jalur.

fenis tanaman yang digunakan antara lain damar (Agathis dammara Lamb.), pucuk merah (Syzygium oleana Br. Ex), dan teh-tehan (Acalypha siamensis Oliv. ex Gage).
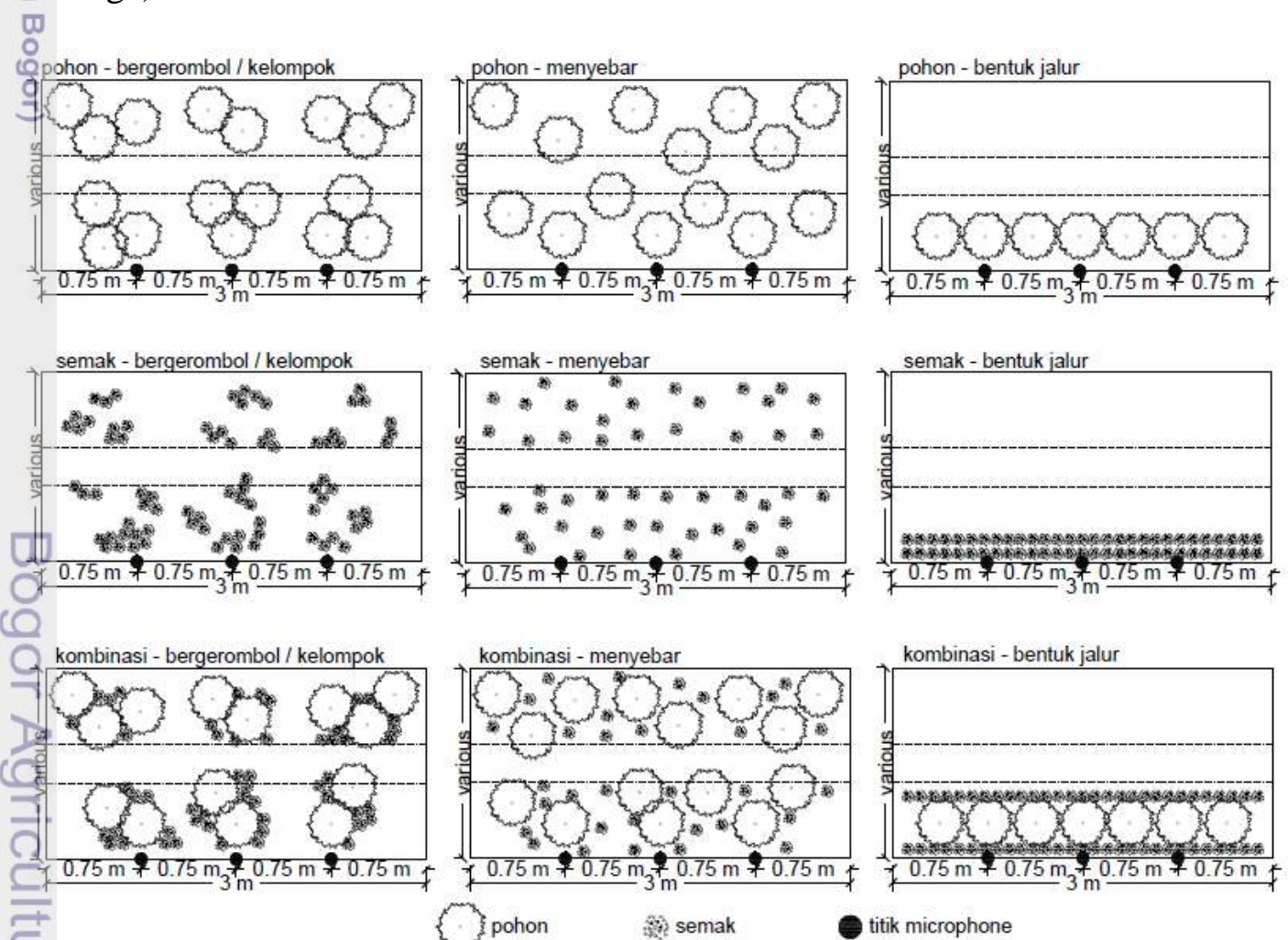

S Soho

3. semak

titik microphone

Gambar 11 Ilustrasi model penyusunan tanaman 
Pada penelitian simulasi terdapat sembilan perlakuan model penyusunan tanaman, seperti yang ditunjukkan pada Gambar 11. Setiap perlakuan tersebut dilakukan pada kedua frame diatas (Gambar 10), sehingga terdapat delapan belas total perlakuan yang diterapkan pada penelitian simulasi. Pada frame 1 , jenis tanaman yang digunakan adalah pohon damar (Agathis dammara Lamb.) dan semak pucuk merah (Syzygium oleana Br. Ex), sedangkan jenis tanaman pada frame 2 adalah pohon damar (Agathis dammara Lamb.) dan semak teh-tehan (Acalypha siamensis Oliv. ex Gage). Perbedaan penggunaan jenis tanaman semak dikarenakan pada saat pengukuran frame 2 tanaman pucuk merah sudah banyak yang layu, sehingga tanaman semak diganti menjadi tanaman teh-tehan. Akan tetapi, kedua jenis tanaman semak memiliki tipe daun yang sama, yaitu tipe daun sedang:

Adapun jumlah tanaman yang digunakan pada penelitian ini tidak selalu sama. Jumlah pohon saat pengukuran pohon berkelompok belum tentu sama dengan.jumlah pohon saat pengukuran pohon berbentuk jalur. Hal ini dikarenakan waktu $\bar{p}$ engukuran pohon berkelompok dengan pohon berbentuk jalur dilakukan pada Fari yang berbeda, sehingga pada saat pengukuran pohon berkelompok jumlahspohon masih banyak yang segar, namun saat pengukuran pohon berbentuk jalur jumlah pohon sudah banyak yang layu. Begitu juga untuk perlakukan semak dan kotinbinasi tanaman.

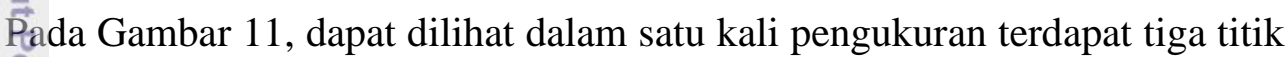
peletakkan microphone, yaitu titik kiri, titik tengah, dan titik kanan. Dalam satu titik terdapat tiga microphone dimana diletakkan pada bagian bawah, tengah, dan atas. Pêngambilan data pada masing-masing titik microphone dilakukan selama 10 detik. Masing-masing bagian microphone (bawah - tengah - atas) dihubungkan denga kabel menuju alat real time band octave analyzer yang berada di luar ruanga semi bebas gema. Alat analyzer diletakkan di luar ruangan semi bebas gema, agar tidak terjadi pemantulan suara. Ilustrasi pengukuran di dalam ruang semi bebas gema ditunjukkan pada Gambar 12.

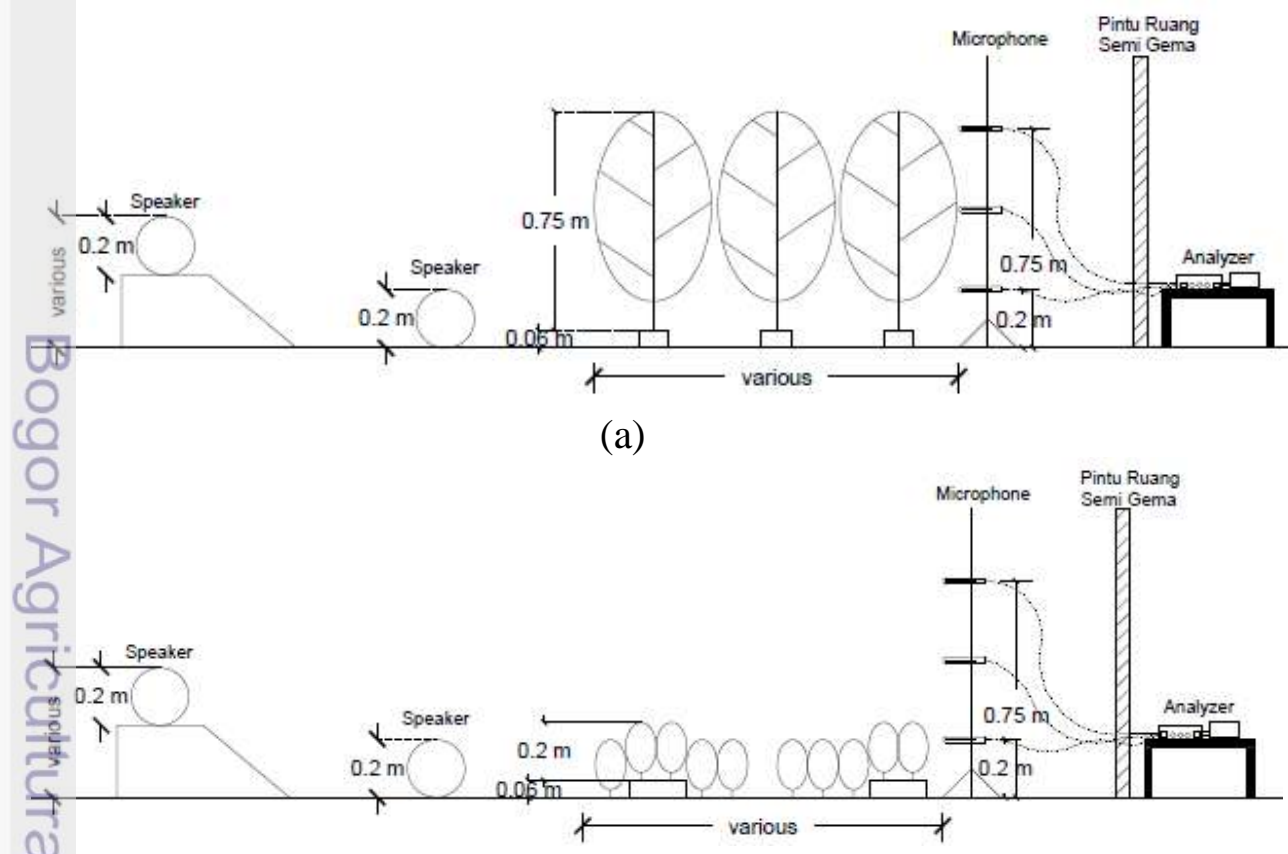

(b) 


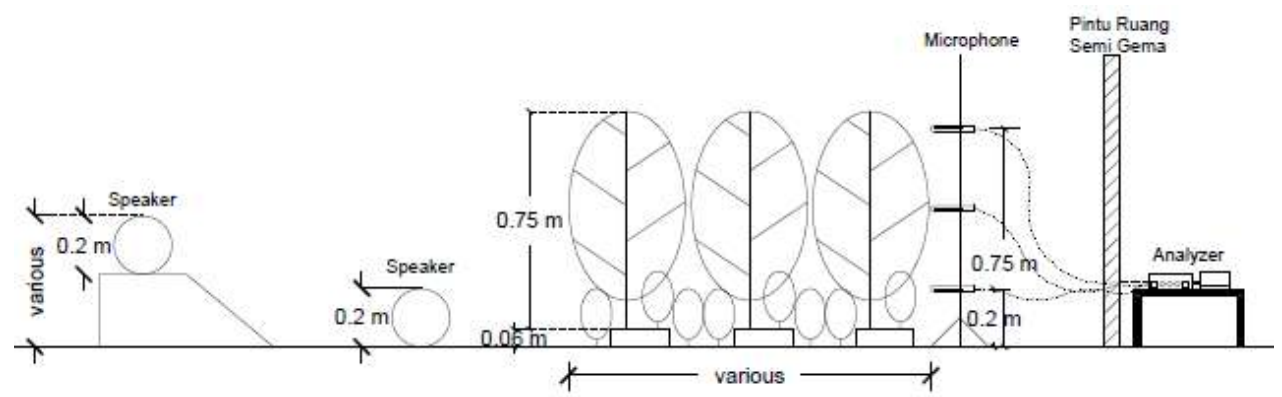

(c)

Gambar 12 Ilustrasi simulasi pengukuran barrier pada

(a) pohon (b) semak (c) kombinasi

Pengukuran dilakukan sebelum dan setelah ada barrier. Tujuannya untuk mengetahui tingkat suara sebelum dan sesudah ada barrier pada tiap jarak yang berbeda. Pengukuran tingkat tekanan suara dilakukan dengan meletakkan speaker Tegak lurus dengan microphone, penghalang (barrier) diletakkan diantara speaker dan microphone. Pengukuran simulasi laboratorium menggunakan dua alat sppeaker sebagai sumber suara di lapang, dengan tinggi $\pm 20 \mathrm{~cm}$ yang menggambarkan tinggi kendaraan.

Frekuensi yang diukur adalah range $20 \mathrm{~Hz}-20000 \mathrm{~Hz}$ yang disesuiakan dengan jangkauan pendengaran telinga normal manusia. Sumber suara menggunakan sumber suara asli dari keadaan di lapangan, dengan mengambil rekaman suara pada sumber suara tersebut untuk melihat frekuensi suara. Rekaman suara inilah yang dijadikan sumber bising pada percobaan simulasi di 㒀boratorium. Pengambilan rekaman suara menggunakan alat perekam merk Sony thpe ICD-PX333 dan ICD-UX71.
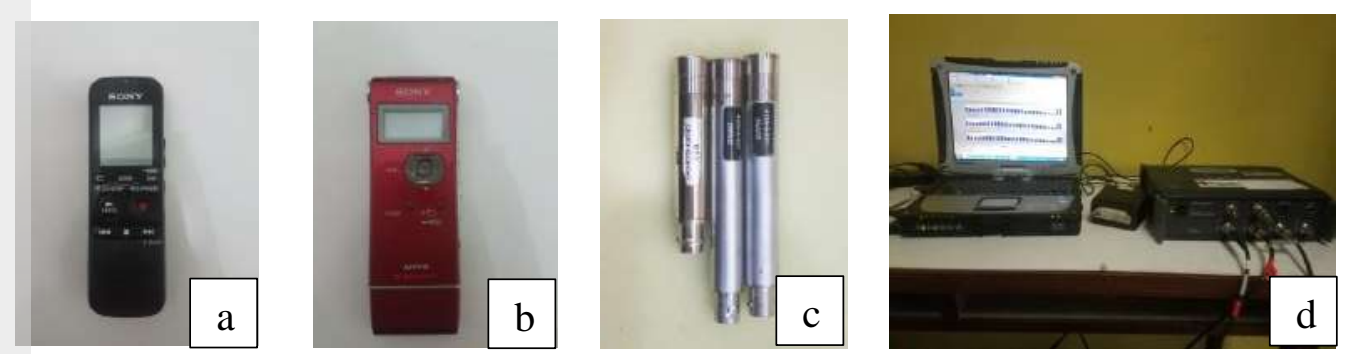

Gambar 13 Alat yang digunakan dalam pengukuran simulasi (a) perekam suara Sony ICD-PX333 (b) perekam suara Sony ICD-UX71 (c) microphone (d) real time octave band Analyzer Onosokki DS-2000 (DS-0223) 


\section{Metode Analisis Data}

Metode analisis yang digunakan dalam penelitian ini meliputi tiga tahapan, yaitu analisis distribusi tingkat bising di kawasan perumahan, analisis efektivitas dinding penghalang dan tanaman, dan analisis persepsi penduduk. Bagan alur penelitian dapat dilihat pada Gambar 14.

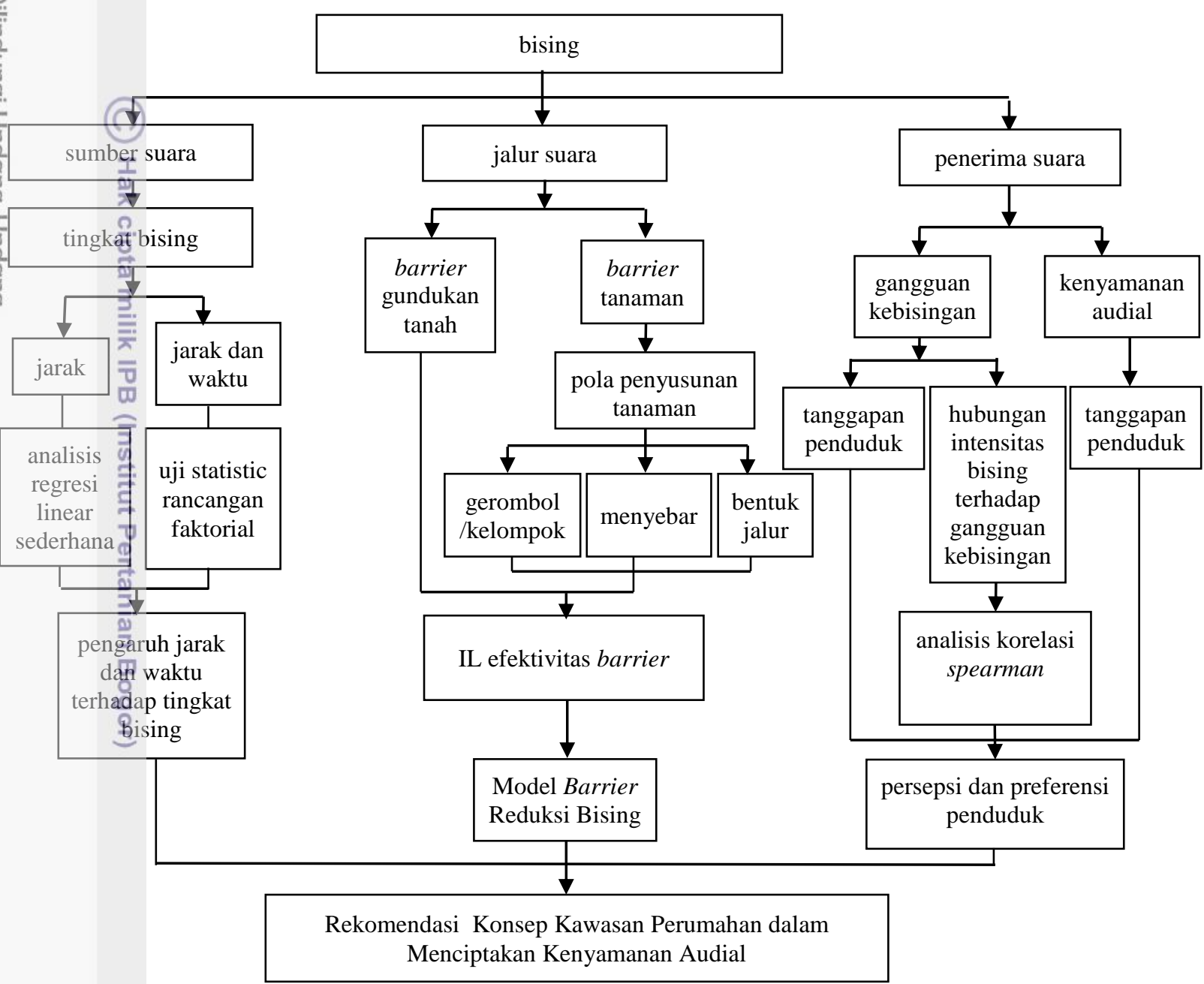

Gambar 14 Bagan alur penelitian

\section{Analisis tingkat kebisingan perumahan}

Data yang diperoleh selama pengukuran 10 menit selanjutnya akan dilakukan perhitungan data untuk mengetahui nilai kebisingan dari hasil pengukuran. Menurut Endi dan Palupi (2011), perhitungan data $\mathrm{L}_{\mathrm{eq}} 1$ menit dapat dihitung dengan menggunakan rumus:

$$
\mathrm{L} \frac{\mathrm{O}}{(}(1 \text { menit })=10 \log \frac{1}{60}\left[\left(10^{0.1 \mathrm{~L} 1}+10^{0.1 \mathrm{~L} 2}+\ldots+10^{0.1 \mathrm{~L} 12}\right) 5\right] \mathrm{dB}(\mathrm{A})
$$

Rumus ini digunakan pada setiap menit hingga diperoleh data $\mathrm{L}_{\mathrm{eq}} 1$ menit. Setelah masing-masing nilai $\mathrm{L}_{\mathrm{eq}} 1$ menit diperoleh, maka dilanjutkan dengan perhitungan $\mathrm{L}_{\mathrm{eq}} 10$ menit dengan rumus: 


$$
\mathrm{L}_{\mathrm{eq}}(10 \text { menit })=10 \log \frac{1}{10}\left[\left(10^{0.1 \mathrm{LI}}+10^{0.1 \mathrm{LII}}+\ldots+10^{0.1 \mathrm{LX}}\right) 1\right] \mathrm{dB}(\mathrm{A}) \ldots . .
$$

Sesuai dengan Keputusan Menteri Lingkungan Hidup No. 48/MENLH/11/1996 tentang Baku Tingkat Kebisingan, maka akan diperoleh nilai rata-rata dari hasil pengukuran $\mathrm{L}_{\text {eq }}$ selama 24 jam. Penelitian ini hanya sebatas pengukuran selama aktivitas 16 jam $\left(\mathrm{L}_{\mathrm{s}}\right)$ dengan selang waktu $06.00-22.00 \mathrm{WIB}$. Setiap pengukuran mewakili selang waktu tertentu dengan menetapkan 4 waktu pengukuran, antara lain L1 (pengukuran pada rentang waktu $06.00-09.00$ ), L2 (pengukuran pada rentang waktu 09.00 - 14.00), L3 (pengukuran pada rentang waktu 14.00 - 17.00), dan L4 (pengukuran pada rentang waktu 17.00 - 22.00). Berdasarkan Menurut Endi dan Palupi 2011, rumus yang digunakan adalah șebagai berikut.

$\mathrm{E}_{e q}(\operatorname{siang})=L_{s}(16 \mathrm{jam})=10 \log \frac{1}{16}\left(\mathrm{Ta} 10^{0.1 \mathrm{La}}+\cdots+\mathrm{Td} 10^{0.1 \mathrm{Ld}}\right) d B(A)$

两

keterangan:

Eeq : kebisingan ekivalen $[\mathrm{dB}(\mathrm{A})]$

$E_{1}, \ldots, L_{12}$ : kebisingan setiap 5 detik selama 60 detik $[\mathrm{dB}(\mathrm{A})]$

$\overrightarrow{\mathrm{E}}_{\mathrm{J}}, \ldots, \mathrm{L}_{\mathrm{X}}$ : kebisingan setiap 1 menit selama 10 menit $[\mathrm{dB}(\mathrm{A})]$

$\mathrm{B}_{\mathrm{s}} \quad$ : Leq di siang hari $[\mathrm{dB}(\mathrm{A})]$

$\mathrm{E}_{\mathrm{a}}, \ldots, \mathrm{T}_{\mathrm{d}}$ : selang waktu pengukuran di siang hari (jam)

\section{Analisis regresi linear sederhana}

Analisis regresi linear sederhana digunakan untuk membuat keputusan apakah naik atau menurunnya variable dependen dapat dilakukan melalui peningkatan variable independen (Sugiyono 2011). Variabel dependen adalah nilai kebisingan dan variable independen adalah jarak. Taraf signifikansi yang digunakan adalah 5\%. Persamaan linear yang digunakan adalah:

Keterangan:

$$
Y=a+b X
$$

Y : Variabel dependen (terikat)

$\mathrm{X} \quad$ : Variabel independen (bebas)

a : konstanta

bJ : koef. regresi (kemiringan), besaran response yang ditimbulkan predictor

\section{Uji statistic rancangan factorial}

Analisis data yang digunakan untuk mengetahui pengaruh jarak dan waktu terhadap tingkat kebisingan adalah uji statistic rancangan factorial. Rancangan (factorial adalah rancangan yang berada dalam satu keadaan dicobakan secara bersamaan dari dua atau lebih percobaan-percobaan tunggal (Zaki et al 2014). Faktor yang digunakan dalam analisis adalah pengaruh waktu terhadap kebisingan, pengaruh jarak terhadap kebisingan, serta interaksi antara waktu dan jarak terhadap kebisingan. Faktor waktu dan jarak diduga berpengaruh terhadap nilai kebisingan yang dihasilkan di setiap titik lokasi. Taraf nyata yang digunakan adalah 5\%. Model linear percobaan factorial yang terdiri dari dua factor adalah: 


$$
Y_{i j k}=\mu+\alpha_{i}+\beta_{j}+\rho_{k}+(\alpha \beta)_{i j}+\varepsilon_{i j k} \ldots \ldots(5)
$$

Keterangan:

Yijk : pengamatan pada kelompok ke- $k$ yang mendapat perlakuan factor A ke- $i$ dan factor B taraf ke-j.

$\mu \quad$ : rataan umum

$\alpha_{i} \quad$ : pengaruh factor A taraf ke- $i$

$\beta_{\mathrm{j}} \quad$ : pengaruh factor B taraf ke- $j$

$\rho_{\mathrm{k}} \quad$ pengaruh kelompok ke- $k$

$(\alpha \beta)_{\mathrm{ij}}$. pengaruh interaksi factor A taraf ke-I dan factor B taraf ke- $j$

$\varepsilon_{\mathrm{ijk}} \quad \frac{\tau}{0}$. komponen galat

\section{Analisis tingkat bising terhadap gangguan kebisingan}

Pada tahap ini dilakukan untuk mengetahui suatu keeratan hubungan antara variable tingkat bising dengan gangguan kebisingan yang dirasakan penduduk perumāhan. Uji statistic yang digunakan adalah korelasi rank Spearman. Untuk mengefahui ada dan tidaknya hubungan antara variable dapat langsung dilihat probablitasnya. Jika probabilitas $>0.05$ maka $\mathrm{H}_{1}$ ditolak, sebaliknya, jika probabilitas $<0.05$ maka $\mathrm{H}_{1}$ diterima. Dalam penelitian ini, hipotesis $\left(\mathrm{H}_{1}\right)$ yang digunâkan adalah ada hubungan antara tingkat bising perumahan IPB 1 Baranangsiang dengan gangguan kebisingan dari penduduk setempat.

\section{Nilai pengurangan suara (insertion loss)}

甘ilai pengurangan suara (insertion loss - IL) adalah selisih tingkat tekanan bunyi ğtara titik pengukuran sebelum dan setelah ada barrier. Nilai pengurangan suara fini akan menjadi acuan dalam membuat model barrier di lokasi perumahan. Menurutt Wang et al (2018), rumus IL adalah sebagai berikut.

$$
L_{D}=S P L_{0}-S P L_{b} \ldots(6)
$$

keterangan:

$\mathrm{L}_{\mathrm{D}} \quad$ : Pengurangan suara (insertion loss $\left.-\mathrm{IL}\right)[\mathrm{dB}]$

$\mathrm{SPL}_{0} \quad$ : sound pressure level sebelum ada barrier $[\mathrm{dB}]$

$\mathrm{SPL}_{\mathrm{b}}$ : sound pressure level setelah ada barrier $[\mathrm{dB}]$

\section{Perumusan rekomendasi}

Pada tahap ini merupakan tahap akhir evaluasi yang menetapkan rekomendasi untuk peningkatan kualitas permukiman dalam mengatasi kebisingan. Rekomendasi diarahkan pada ilustrasi desain pada barrier yang dapat digunakan pada kawasan perumahan, seperti mendesain gundukan tanah dan penambahan jenis tanaman pada kawasan rumah.

Pada ilustrasi desain barrier, menggunakan jenis tanaman yang mampu untuk- mereduksi bising serta dikombinasikan dengan gundukan tanah. Penggunaan barrier disesuaikan dengan luas lahan yang tersedia, sehingga barrier dapat diterapkan di kawasan perumahan dan memiliki nilai estetika. 


\section{HASIL DAN PEMBAHASAN}

\section{Kondisi Umum}

\section{Letak dan Kondisi Perumahan IPB 1 Baranangsiang}

Wilayah penelitian adalah perumahan yang berada di Kelurahan Baranangsiang, Kecamatan Bogor Timur, Kota Bogor. Berdasarkan geografis dan administrative, perumahan tersebut terletak di koordinat $6^{\circ} 35^{\prime} 57.9^{\prime \prime}-6^{\circ} 59^{\prime} 94.23^{\prime \prime}$

CS dan $106^{\circ} 49^{\prime} 02.6^{\prime \prime}-106^{\circ} 81^{\prime} 73.99^{\prime \prime} \mathrm{BT}$, serta berbatasan dengan:

utara : Jl. Padi dan Jl. Tol Jagorawi

느는 : Jl. Sinangling Padi Ramp dan Jl. Pandu Raya

Selatan : permukiman warga, sekolah, lapangan futsal

barat : Kawasan perdagangan- jasa dan permukiman warga

Eokasi perumahan tersebut juga dekat dengan Jl. Binamarga, dimana menurut ÉTRW Kota Bogor 2011 - 2031, area tersebut akan dijadikan rencana alokasi rüang khusus kuliner.
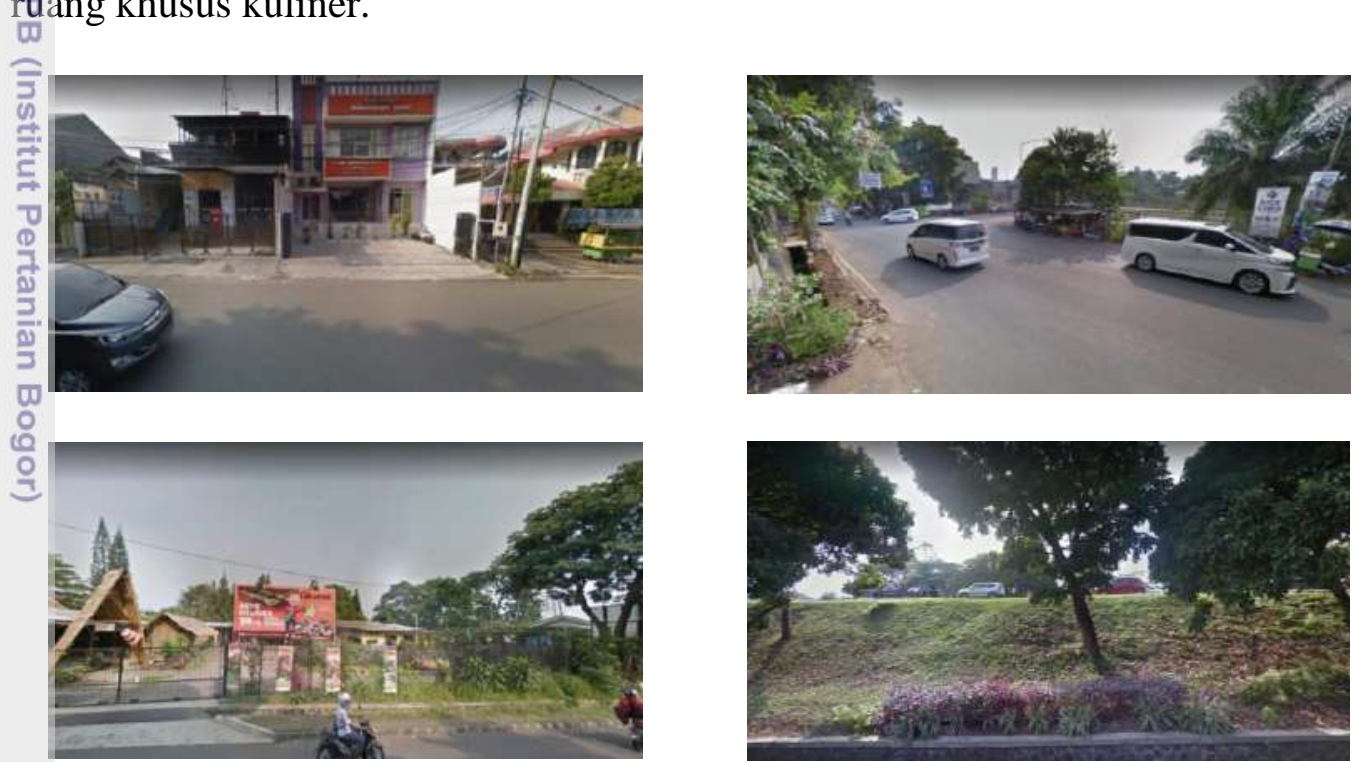

Gambar 15 Bagian utara dan timur Perumahan IPB 1 Baranangsiang

Pada bagian utara dan timur perumahan tersebut dekat dengan persimpangan jalan tol menuju jalan sekunder arteri dan sebagian lahan sudah dialokasikan menjadi pelayanan jasa, seperti rumah makan, tempat bimbingan belajar, dan klinik kecantikan.

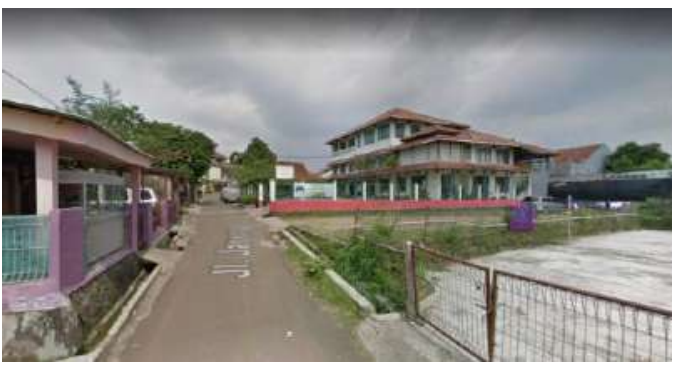

Gambar 16 Bagian selatan Perumahan IPB 1 Baranangsiang 
Pada bagian selatan perumahan, terdapat sekolah dan lapangan futsal, serta permukiman warga. Perumahan IPB 1 Baranangsiang menjadi akses masuk satusatunya menuju sekolah dasar, lapangan futsal, dan permukiman warga. Lokasi yang strategis tersebut menjadikan area perumahan tersebut banyak dilewati oleh kendaraan.

\section{Kondisi Iklim}

Menurut BPS Kota Bogor (2018), suhu rata-rata tiap bulan Kota Bogor mencapai $27.3^{\circ} \mathrm{C}$, dengan suhu terendah $22.2^{\circ} \mathrm{C}$ dan suhu tertinggi mencapai $33^{\circ}$ C. Kelembaban udara mencapai $82 \%$ dan curah hujan rata-rata setiap bulan 345 mm dengan curah hujan terbesar pada bulan Februari 2017.

\section{Kondisi Sosial dan Ekonomi}

Jumlah penduduk Kota Bogor menurut BPS Kota Bogor (2018) sebanyak 1 $0810 \bar{\theta} 9$ jiwa, yang terdiri dari laki-laki sebanyak 548196 jiwa dan perempuan $5328 \overline{5}$ jiwa. Jumlah penduduk Kota Bogor mengalami peningkatan dari tahun 2016, yaitu sebesar $1.53 \%$ atau 16322 jiwa. Jumlah penduduk untuk wilayah kecamatan Bogor Timur adalah sebesar 106029 jiwa atau sekitar 9.81\% dari luas wilaya kecamatan Bogor Timur $(10.15 \mathrm{~km} 2)$. Laju pertumbuhan penduduk di Kecan ẳan Bogor Timur dari tahun 2000 - 2010 adalah sebesar 2.15\%. Jumlah penduđuk terbanyak di Kota Bogor berada di Kecamatan Bogor Barat, dengan jumlalf penduduk sebanyak 239860 jiwa, sedangkan kecamatan populasi terkecil adalah Kecamatan Bogor Tengah memiliki 104853 penduduk. Kenaikan jumlah penduểuk tersebut dipengaruhi oleh tersedianya lapangan pekerjaan dengan sektor terbanyak di bidang perdagangan (BPS Kota Bogor 2018).

Berdagangan merupakan kegiatan ekonomi utama di daerah perkotaan. Sebagai kota tujuan wisata utama bagi masyarakat Jakarta, perdagangan dan pelayanan jasa di Kota Bogor sangat potensial untuk dikembangkan. Keberadaan Kelurahan Baranangsiang yang dekat dengan pintu masuk Kota Bogor (Jalan Tol Jagorawi dan Terminal Antar Kota Baranangsiang), memiliki potensi perdagangan dan jasa yang tinggi. Menurut RTRW Kota Bogor 2011 - 2031, Kelurahan Baranangsiang merupakan area permukiman, namun pada kelurahan tersebut juga terdapat pusat kuliner, pertokoan, dan penginapan untuk menarik minat wisatawan.

\section{Kondisi Topografi dan Geologi}

Kota Bogor memiliki wilayah dengan kontur berbukit dan bergelombang dengan ketinggian bervariasi, ketinggian minimum $190 \mathrm{~m}$ dan ketinggian maksimum $330 \mathrm{~m}$ di atas permukaan laut. Wilayah Kecamatan Bogor Timur memiliki lahan datar dengan kemiringan $0-2 \%$ seluas 182.30 ha, seluas 722.62 ha merupakan lahan landai dengan kemiringan $2-15 \%$, seluas 56.03 ha merupakan lahan agak curam dengan kemiringan 15 - 25\%, seluas 44.25 ha merupakan lahan curam dengan kemiringan 25-40\%, serta seluas 9.80 ha merupakan lahan sangat curam dengan kemiringan $>40 \%$.

Jenis tanah pada wilayah Kecamatan Bogor Timur adalah aluvial kelabu (218.51 ha) dan latosol cokelat kemerahan (796.49 ha). Kondisi geologi wilayah Kecamatan Bogor Timur adalah kipas alluvial (304.21 ha) dan tufa (710.79 ha). 


\section{Analisis Tingkat Kebisingan}

\section{Jenis dan Sumber Bising}

Sumber kebisingan dominan pada lokasi penelitian berasal dari aktivitas lalu lintas kendaraan bermotor. Kombinasi bising yang dihasilkan kendaraan bermotor merupakan interaksi antara mesin, ban, dan permukaan jalan (The Vehicles Technologies Office 2012). Beberapa factor yang mempengaruhi kebisingan lalu lintas, diantaranya jenis kendaraan, jenis mesin, kecepatan lalu lintas, jenis perkerasan, jarak ke sumber bising, barrier, topografi, dan cuaca. Tingkat kecepatan yang lebih tinggi dihasilkan oleh kendaraan yang lebih berat, kecepatan yang lebih tinggi, lereng yang menanjak, jembatan yang terlalu tinggi, dan kelembaban yang relative tinggi (Seong et al 2011).

웅

\section{Tingkat Kebisingan Hari Libur dan Hari Kerja}

Sumber kebisingan di lokasi penelitian termasuk kedalam kebisingan lalu 耳intas. Menurut Djalante (2010) kebisingan lalu lintas merupakan kebisingan yang đitimbulkan oleh kendaraan bermotor berasal dari mesin, knalpot, dan interaksi reda dengan jalan. Selain itu, perumahan tersebut jugaberbatasan dengan jalan tol Jagorawi, jalan arteri sekunder (Jl. Pandu Raya), dan jalan kolektor primer (Jl. Padi dan Jl. Sinangling Padi Ramp). Menurut Perda Kota Bogor Nomor 4 Tahun 2016 tentang Garis Sempadan, jalan arteri sekunder merupakan jalan arteri dalam skala perkotaan. Jalan kolektor sekunder merupakan jalan yang melayani ẩgkutan pengumpulan atau pembagian dengan ciri-ciri perjalanan jarak sedang, kecepatan rata-rata sedang, dan jumlah jalan masuk dibatasi, dengan peranan pelayanan jasa distribusi untuk masyarakat di dalam kota.

Berdasarkan hasil pengukuran tingkat kebisingan di perumahan tersebut, điketahui bahwa setiap titik memiliki tingkat kebisingan yang berbeda, serta waktu pengukuran sebanyak empat kali dalam satu hari menghasilkan tingkat bising yang berbeda-beda. Faktor yang mempengaruhi diantaranya waktu pengukuran dan jarak titik pengukuran dari sumber bising. Menurut KEP48/MNLH/11/1996 tentang Baku Tingkat Kebisingan, secara keseluruhan tingkat kebisingan yang terjadi pada perumahan IPB Baranangsiang 1 melebihi baku mutu yang telah ditetapkan.

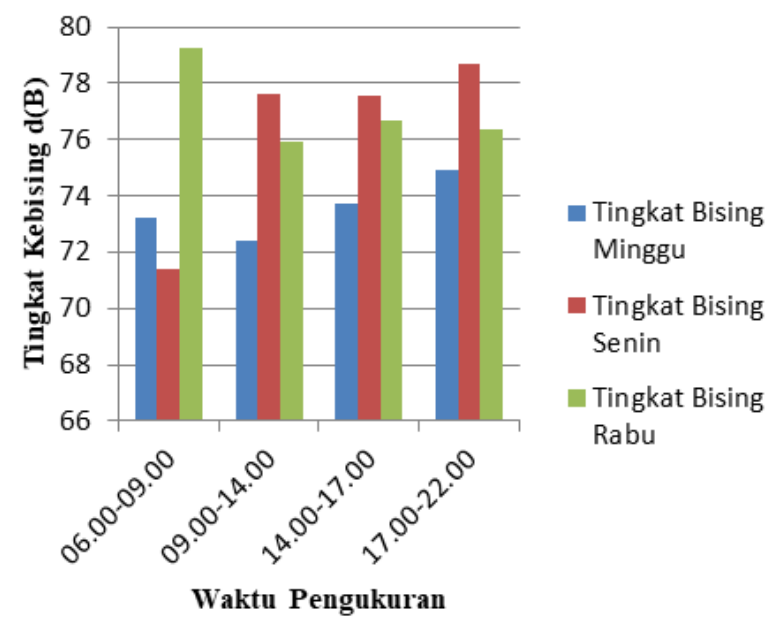

Gambar 17 Tingkat kebisingan rata-rata 16 jam $\left(\mathrm{L}_{\mathrm{s}}\right)$ 
Berdasarkan Gambar 17 dapat dilihat bahwa pengukuran tingkat kebisingan $\mathrm{L}_{\mathrm{s}}$ yang terjadi melebihi baku mutu yang ditetapkan. Nilai $\mathrm{L}_{\mathrm{s}}$ pada hari Senin tanggal 1 April 2019 memiliki nilai yang lebih tinggi dibandingkan dengan hari lain, yaitu $89.2 \mathrm{~dB}$, sedangkan nilai $\mathrm{L}_{\mathrm{s}}$ tertinggi kedua adalah $87.54 \mathrm{~dB}$ yang terjadi pada hari Rabu tanggal 3 April 2019, kemudian diikuti hari Minggu tanggal 31 Maret 2019 memiliki nilai $\mathrm{L}_{\mathrm{s}} 85.016 \mathrm{~dB}$. Dari ketiga data tersebut dapat diketahui bahwa tingkat kebisingan hari kerja (Senin dan Rabu) lebih besar daripada hari libur (Minggu). Pada saat hari kerja, puncak meningkatnya jumlah kendaraan terjadi pada jam-jam sibuk yaitu pagi hari saat jam pergi kerja, kuliah, sekolah, serta pada saat sore hari saat jam pulang kerja. Pada saat hari libur, aktivitass kendaraan di perumahan tersebut menjadi berkurang, karena warga di perumăhan tersebut lebih banyak menghabiskan waktu di rumah untuk beristifrahat.

Hasil pengukuran tingkat kebisingan berdasarkan empat periode waktu pada hari 1] bur ditunjukkan pada Gambar 18, hasil pengukuran tingkat kebisingan berdasärkan empat periode waktu pada hari kerja I dan II ditunjukkan pada Gamb品 19 dan 20.

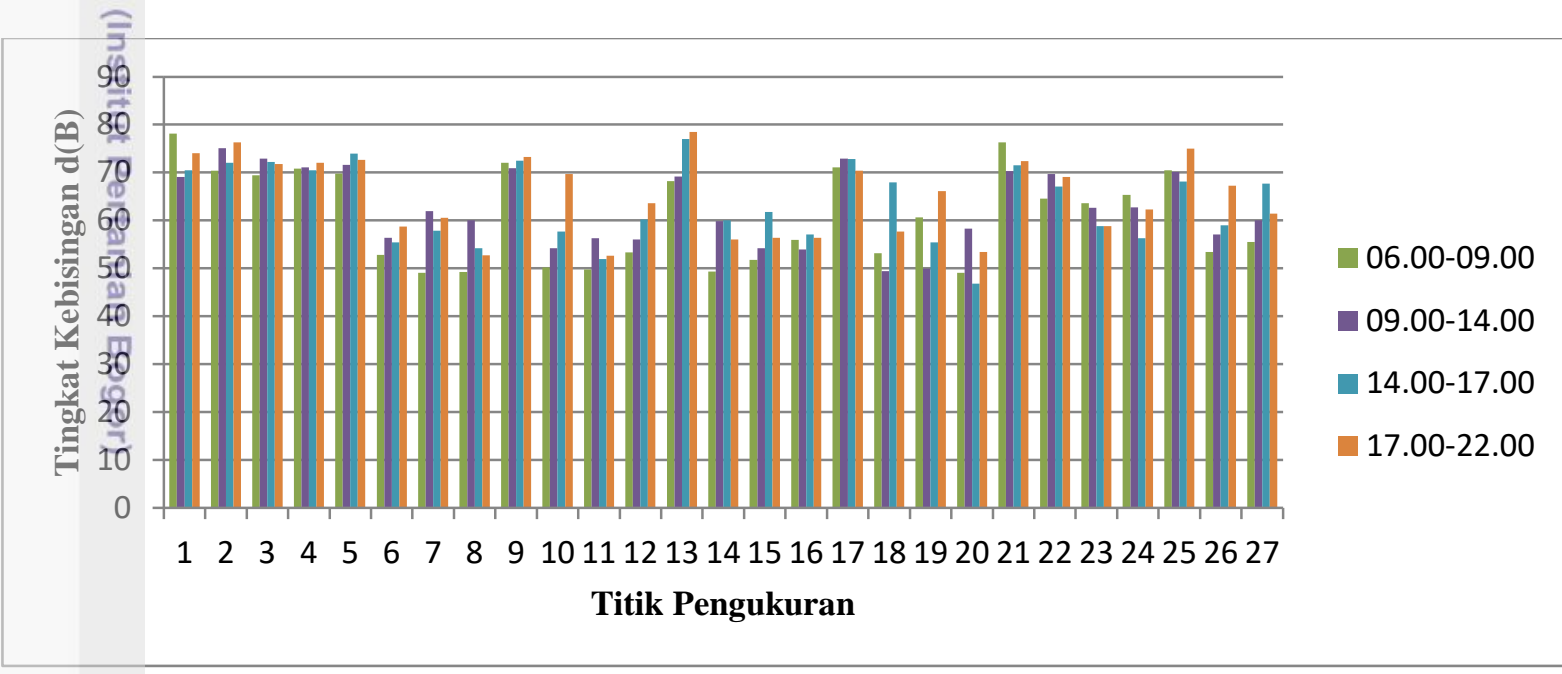

Gambar 18 Tingkat kebisingan rata-rata pada hari libur (Minggu)

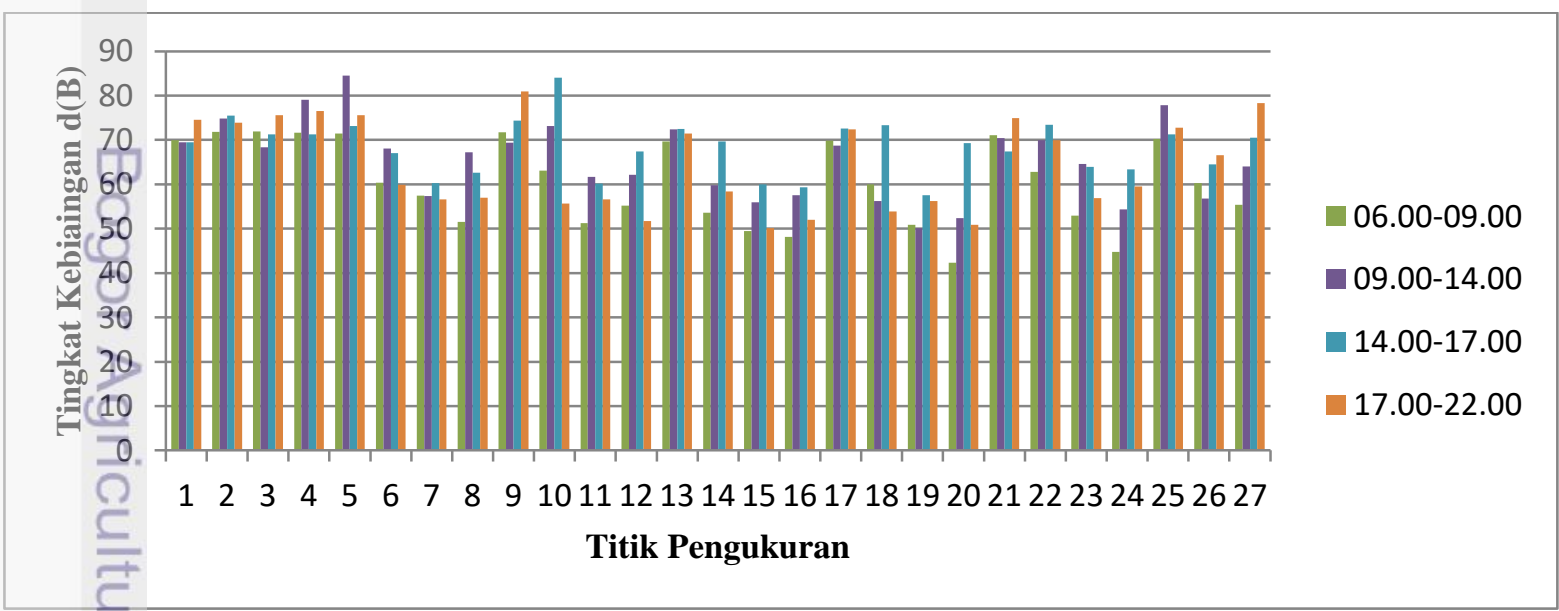

Gambar 19 Tingkat kebisingan rata-rata pada hari kerja I (Senin) 


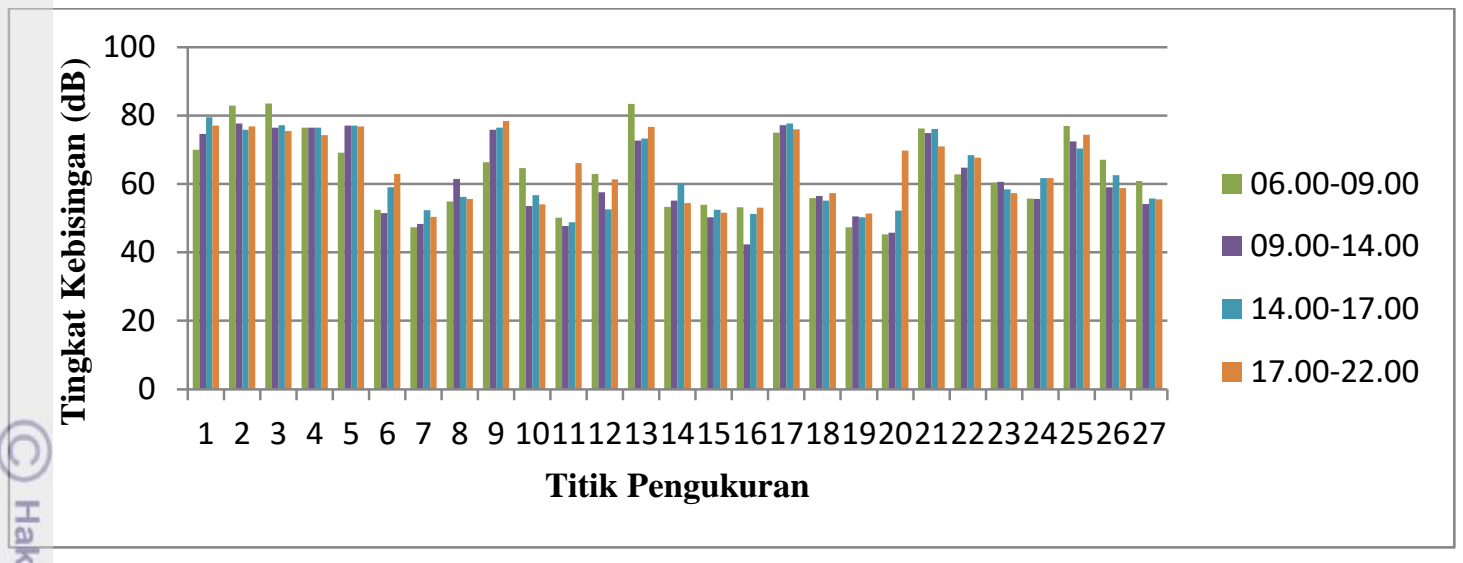

Gambar 20 Tingkat kebisingan rata-rata pada hari kerja II (Rabu)

Dari gambar diatas, dapat dilihat bahwa intensitas kebisingan yang paling inggi adalah pada selang waktu pengukuran pagi, sore, dan malam hari (pukul 06.00-09.00 WIB, pukul 14.00-17.00 WIB, dan pukul 17.00-22.00 WIB). Pada hari libur (Minggu) tingkat kebisingan yang paling tinggi terjadi pada malam hari, sedangkan pada hari kerja (Senin dan Rabu) tingkat kebisingan yang paling tinggi terjadi pada sore dan malam hari. Perbedaan waktu pengukuran akan menyebabkan intensitas kendaraan yang berbeda dan akan mempengaruhi tingkat Kebisingan. Pada saat pagi-sore-malam hari, aktivitas manusia dan jumlah volume Kendaraan yang melintas lebih banyak dibandingkan dengan pagi dan siang hari. כ)

\section{Pengaruh Jarak terhadap Kebisingan}

एँ Pengaruh jarak terhadap kebisingan di lokasi penelitian dibagi menjadi 6 (enam) jalur transek. Berikut pembagian jalur transek dapat dilihat pada Gambar 21.

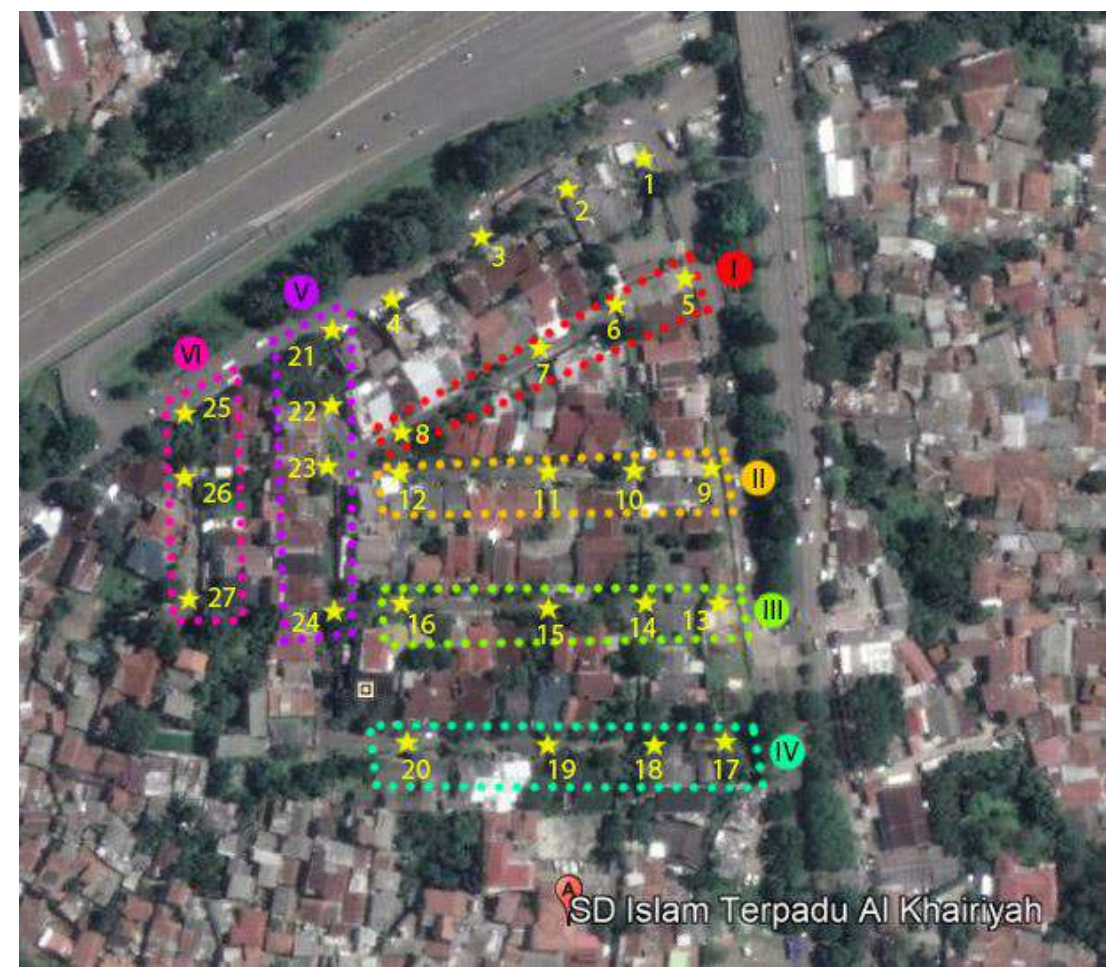

Gambar 21 Jalur transek pada lokasi penelitian 
Pada setiap jalur transek akan dibandingkan dan dianalisis apakah jarak berpengaruh terhadap tingkat kebisingan. Pada jalur transek I - IV yang terdiri dari titik $5-20$, merupakan jalur dimana sumber bising utama berasal dari sebelah timur (Jl. Pandu dan Jl. Sinangling Padi), sedangkan jalur transek V - VI yang terdiri dari titik 21 - 27 merupakan jalur dimana sumber bising utama berasal dari sebelah utara (Jl. Tol Jagorawi dan Jl. Padi). Grafik perbandingan setiap jalur transek I - IV ditunjukkan pada Gambar 22.
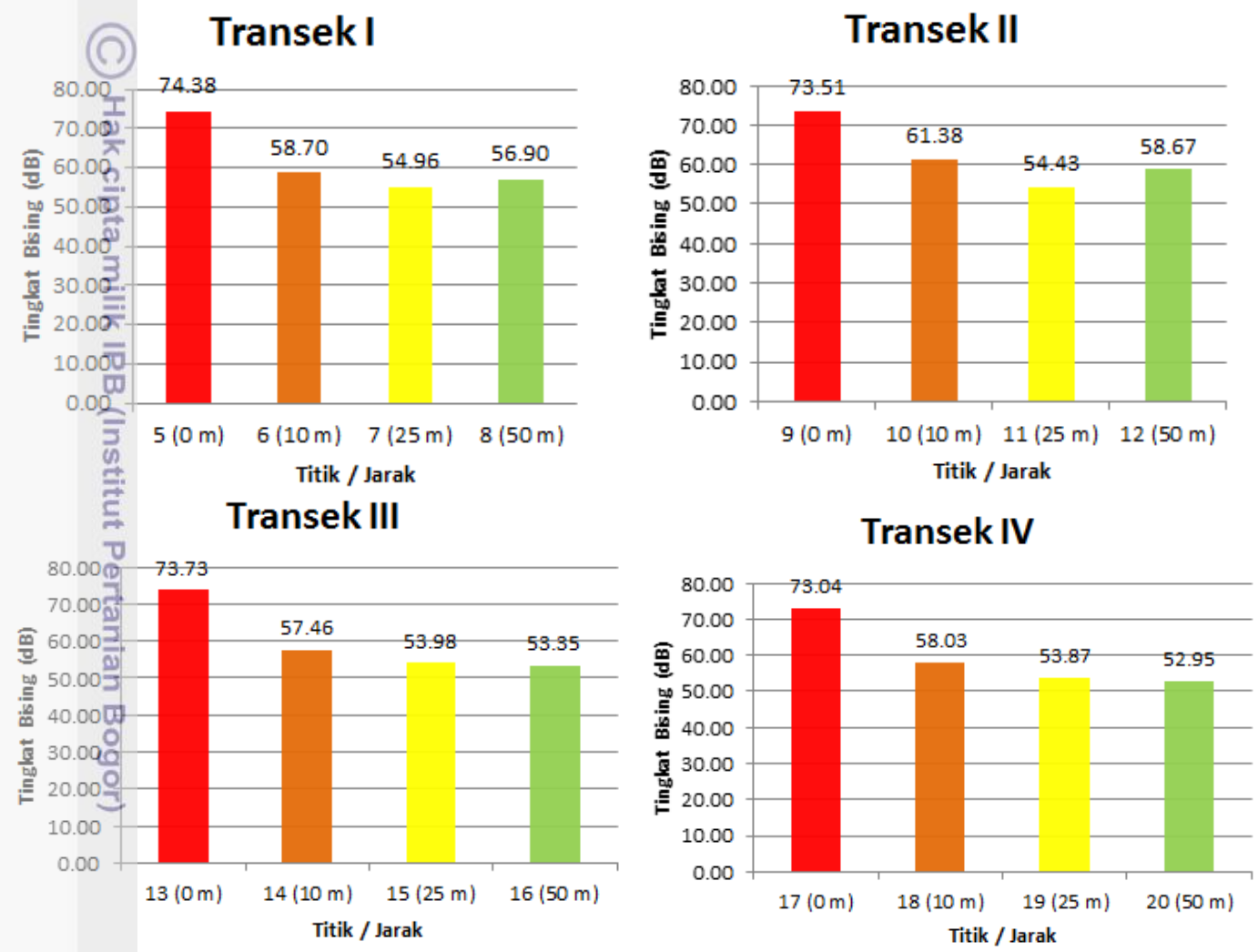

Gambar 22 Perbandingan jalur transek I - IV

Gambar diatas menunjukkan bahwa jarak berpengaruh terhadap nilai kebisingan. Semakin jauh rumah dari sumber bising maka nilai bising yang didapatkan juga semakin berkurang. Pada jalur transek I menunjukkan bahwa selisih penurunan tingkat kebisingan dari jarak $0 \mathrm{~m}-10 \mathrm{~m}$ cukup besar, yaitu $15.68 \mathrm{~dB}$, serta selisih penurunan tingkat bising pada jarak $10 \mathrm{~m}-25 \mathrm{~m}$ cukup kecil, yaitu $3.74 \mathrm{~dB}$. Akan tetapi, selisih penurunan tingkat bising pada jarak $25 \mathrm{~m}$ - 50 adalah $-1.94 \mathrm{~dB}$ atau dengan kata lain pada jarak $50 \mathrm{~m}$ tingkat kebisingan semakin bertambah. Begitu juga pada jalur transek II menunjukkan bahwa selisih penurunan tingkat kebisingan dari jarak $0 \mathrm{~m}-10 \mathrm{~m}$ cukup besar, yaitu $12.13 \mathrm{~dB}$, sertaselisih penurunan tingkat bising pada jarak $10 \mathrm{~m}-25 \mathrm{~m}$ berkurang $6.95 \mathrm{~dB}$. Akan tetapi, selisih penurunan tingkat bising pada jarak $25 \mathrm{~m}-50 \mathrm{~m}$ adalah -4.24 $\mathrm{dB}$ atau dengan kata lain pada jarak $50 \mathrm{~m}$ tidak ada pengurangan tingkat kebisingan. Peristiwa ini menunjukkan bahwa pada jarak $0 \mathrm{~m}$ dari sumber suara (titik 5 -dan titik 9) tingkat kebisingan dari suara kendaraan lebih besar, kemudian pada jarak $10 \mathrm{~m}$ tingkat kebisingan juga semakin berkurang dengan selisih 12.13 dB hingga $15.68 \mathrm{~dB}$. Selain faktor jarak, faktor lain yang menyebabkan selisih 
pengurangan yang cukup besar adalah posisi rumah-rumah di jarak $10 \mathrm{~m}$ yang menghadap arah timur ke barat dapat sekaligus menjadi barrier bagi rumahrumah di jarak $25 \mathrm{~m}$ dan $50 \mathrm{~m}$. Sementara itu, selisih pengurangan tingkat kebisingan dari jarak $10 \mathrm{~m}-25 \mathrm{~m}$ adalah $3.74 \mathrm{~dB}-6.95 \mathrm{~dB}$. Selisih tersebut tidak cukup besar dibandingkan dengan jarak sebelumnya karena pengurangan sisa suara dari adanya barrier dinding rumah cukup besar. Pada jarak berikutnya, yaitu jarak $25 \mathrm{~m}-50 \mathrm{~m}$ tingkat kebisingan semakin bertambah antara $1.94 \mathrm{~dB}$ hingga $4.24 \mathrm{~dB}$ atau dapat dikatakan tidak ada pengurangan suara sama sekali. Hal ini dikarenakan tingkat kebisingan pada jarak rumah $50 \mathrm{~m}$ memiliki posisi titik yang berdekatan (titik 8 dan 12). Kedua titik tersebut hanya dipisahkan oleh lahan yang berisikan tanaman yang ditanam tidak rapat, sehingga apabila kendaraan melintas melewati salah satu titik tersebut, suara tidak akan dapat diserap atau dipantulkan dengan baik oleh tanaman yang ada diantara kedua titik tersebut.

Pada jalur transek III dan IV menunjukkan bahwa jarak berpengaruh terhadap tingkat bising, semakin jauh dari sumber suara maka semakin kecil 需gkat bising yang dihasilkan. Pada jalur transek III menunjukkan bahwa selisih penurunan tingkat kebisingan dari jarak $0 \mathrm{~m}-10 \mathrm{~m}$ cukup besar yaitu $16.27 \mathrm{~dB}$. Sementara itu, selisih penurunan tingkat bising pada jarak $10 \mathrm{~m}-25 \mathrm{~m}$ cukup kecil, yaitu $3.48 \mathrm{~dB}$, sedangkan selisih penurunan tingkat bising pada jarak $25 \mathrm{~m}-$ $50 \mathrm{~m}$ adalah $0.69 \mathrm{~dB}$ atau dengan kata lain tidak ada pengaruh pengurangan tingkat kebisingan. Hal tersebut juga terjadi pada jalur transek IV dimana selisih penurunan tingkat kebisingan dari jarak $0 \mathrm{~m}-10 \mathrm{~m}$ cukup besar yaitu $15.01 \mathrm{~dB}$. Sementara itu, selisih penurunan tingkat bising pada jarak $10 \mathrm{~m}-25 \mathrm{~m}$ cukup Recil, yaitu $4.16 \mathrm{~dB}$, sedangkan pada selisih penurunan tingkat bising pada jarak $25 \mathrm{~m}-50 \mathrm{~m}$ adalah $0.92 \mathrm{~dB}$ atau dengan kata lain tidak ada pengaruh Bengurangan tingkat kebisingan. Peristiwa tersebut dikarenakan pada jarak $0 \mathrm{~m}$ (titik 13 dan 17) memiliki sumber suara yang lebih tinggi, namun pada jarak $10 \mathrm{~m}$ tingkat kebisingan juga semakin berkurang. Selain factor pertambahan jarak, factor lain yang menyebabkan selisih pengurangan yang cukup besar adalah posisi rumah-rumah di jarak $10 \mathrm{~m}$ dapat sekaligus menjadi barrier bagi rumah-rumah di belakangnya, yaitu jarak $25 \mathrm{~m}$ dan $50 \mathrm{~m}$. Selisih pengurangan tingkat kebisingan pada jarak $10 \mathrm{~m}-25 \mathrm{~m}$ dapat dikatakan normal, yaitu berkisar antara $3.48 \mathrm{~dB}-$ $4.16 \mathrm{~dB}$. Akan tetapi, pada jarak $25 \mathrm{~m}-50 \mathrm{~m}$ selisih pengurangan tingkat kebisingan hanya berkisar antara $0.69 \mathrm{~dB}-0.92 \mathrm{~dB}$ atau dengan kata lain tidak ada pengaruh pengurangan kebisingan, padahal selisih jarak cukup besar. Hal tersebut dikarenakan propagasi sumber suara pada bagian timur yang cukup besar sudah terhalang atau dipantulkan pada barrier dinding rumah yang ada di jarak 10 $\mathrm{m}$, dimana orientasi rumah yang berada pada jarak $10 \mathrm{~m}$ menghadap dari timur ke barat, sehingga sisa suara yang menyebar ke jarak $25 \mathrm{~m}$ dan $50 \mathrm{~m}$ juga tidak terlalu besar dan semakin berkurang seiiring dengan pertambahan jarak. Hal ini terbukti bahwa dinding rumah merupakan salah satu barrier yang cukup efektif cuntuk mengurangi bising hingga $15 \mathrm{~dB}$ (Mashuri 2007). Dalam penelitian ini barrier dinding rumah mampu mereduksi bising antara $15.01 \mathrm{~dB}-16.27 \mathrm{~dB}$. 
Transek V

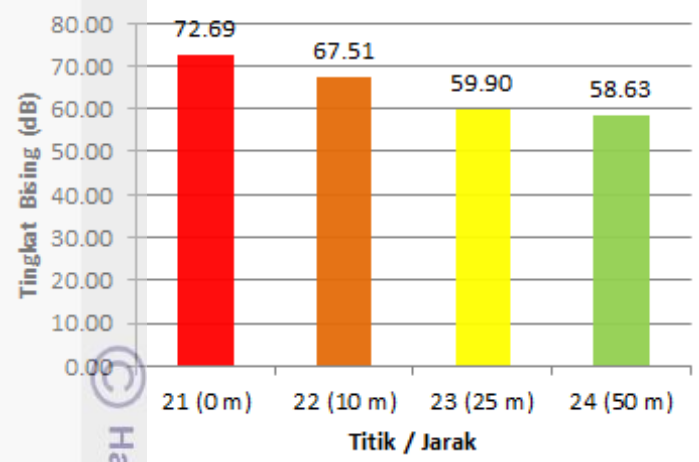

Transek VI

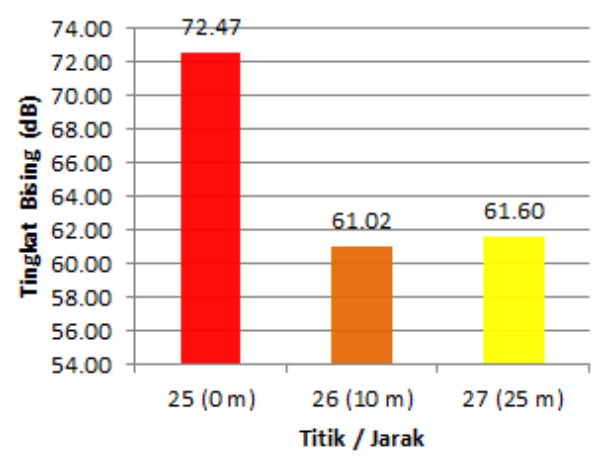

Gambar 23 Perbandingan jalur transek V dan VI

Pada Gambar 23 menunjukkan pada transek V, jarak berpengaruh terhadap tingkat. bising. Selisih pengurangan tingkat kebisingan dari jarak $0 \mathrm{~m}-10 \mathrm{~m}$ adalah $5.18 \mathrm{~dB}$. Apabila dibandingkan dengan transek I - IV, selisih pengurangan tingka $10 \mathrm{~m}$ di transek $\mathrm{V}$ tidak terdapat dinding rumah yang dapat dijadikan barrier sepertîn pada transek sebelumnya. Oleh karena itu, selisih pengurangan tingkat kebisitangan hanya disebabkan oleh faktor jarak. Kemudian selisih pengurangan tingkatikebisingan dari jarak $10 \mathrm{~m}-25 \mathrm{~m}$ cukup besar, yaitu $7.61 \mathrm{~dB}$, namun selisihpengurangan tingkat kebisingan dari jarak $25 \mathrm{~m}-50 \mathrm{~m}$ tidak cukup besar yaitu hanya $1.27 \mathrm{~dB}$ atau dengan kata lain pada jarak $50 \mathrm{~m}$ hampir tidak ada penguẹangan suara. Hal ini dikarenakan titik 24 memiliki topografi yang lebih tinggi glibandingkan titik 23 (jarak $25 \mathrm{~m}$ ), titik 22 (jarak $10 \mathrm{~m}$ ), dan titik 21 (jarak $0 \mathrm{~m}$ ), Ssehingga apabila terdapat kendaraan yang melintas pada jalur transek V memeflukan usaha yang lebih untuk mencapai titik 24. Menurut White dan Walker (1982), kemiringan jalan dapat mempengaruhi kebisingan. Pada tanjakan jalan, dibutuhkan torsi yang lebih besar dibandingkan saat jalan rata, agar kendaraan dapat bergerak. Untuk menghasilkan torsi yang lebih besar, dibutuhkan perseneling rendah dengan putaran mesin tinggi, sehingga akan menghasilkan kebisingan yang lebih tinggi. Demikian pada saat kendaran menuruni jalan, perseneling rendah dibutuhkan untuk membantu pengereman, agar rem menjadi lebih efektif. Dari pernyataan diatas dapat disimpulkan bahwa apabila jalan lebih curam maka kendaraan akan memerlukan usaha lebih untuk dapat melewati/menanjak jalan tersebut, salah satunya menambah kecepatan kendaraan, sehingga gelombang suara yang diterima pun akan lebih tinggi.

Adapun pada transek VI terlihat selisih pengurangan tingkat kebisingan dari jarak $0 \mathrm{~m}-10 \mathrm{~m}$ cukup besar, yaitu $11.45 \mathrm{~dB}$. Selain faktor topografi yang lebih curam dibandingkan dengan transek $\mathrm{V}$, faktor lain yang mempengaruhi pengurangan tingkat kebisingan yang cukup tinggi adalah keberadaan rumah yang terdapat pada jarak $0 \mathrm{~m}$ (titik 25). Rumah pada titik tersebut merupakan rumah dengantipe rumah bertingkat, sehingga keberadaan rumah tersebut dapat menjadi barrier pada rumah-rumah jarak $10 \mathrm{~m}$ dan $25 \mathrm{~m}$. Akan tetapi, pada jarak $10 \mathrm{~m}-$ 25 mtidak ada pengurangan tingkat kebisingan atau dengan kata lain pada jarak 25 m Gingkat bising meningkat daripada jarak $10 \mathrm{~m}$, yaitu sebesar $0.58 \mathrm{~dB}$. Peningkatan tingkat kebisingan pada jarak 25 m (titik 27) dikarenakan titik 
tersebut berbatasan dengan pemukiman lain, sehingga terdapat faktor lain yang mempengaruhi tingkat bising di titik 27.

Berdasarkan analisis regresi sederhana variable $\mathrm{Y}$ adalah tingkat kebisingan, sedangkan variable $\mathrm{X}$ adalah jarak dari sumber bising. Perumahan IPB 1 Baranangsiang memiliki nilai $\mathrm{R}^{2}$ atau koefisien determinasi sebesar 0.763 , artinya variable jarak mempengaruhi kebisingan sebesar 76\%, sedangkan 24\% lainnya merupakan variabel lain yang mempengaruhi kebisingan. Variabel lain yang mempengaruhi tingkat bising di perumahan tersebut dapat berupa kondisi topografi, barrier, dan aktivitas di dalam lingkungan perumahan tersebut. Topografi perumahan, pada transek 5 dan 6 , tersebut memang lebih tinggi đïbandingkan dengan sumber suara, sehingga gelombang suara menyebar dengan

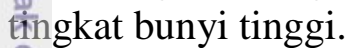

Barrier tanaman yang terdapat di depan halaman masjid, yang dekat dengan tîtik 8 dan 12, memiliki tinggi yang lebih rendah daripada tinggi bangunan serta jeletakkan tanaman yang tidak rapat, sehingga gelombang suara pun dapat melewati barrier tersebut. Selain itu, factor aktivitas di dalam lingkungan perumahan tersebut juga dapat mempengaruhi nilai kebisingan, seperti sekolah dan lapangan futsal yang terletak di dalam perumahan tersebut. Perumahan tersebut merupakan akses masuk menuju sekolah dan lapangan tersebut. Pada saat pägi hari banyak kendaraan yang melewati perumahan menuju sekolah tersebut, begitu juga pada saat sore hari banyak kendaraan yang menuju lapangan futsal.

Nilai p-value di Perumahan IPB 1 Baranangsiang adalah 0.000001, menunjukkan bahwa hubungan jarak dan variable tingkat bising berpengaruh Signifikan. Persamaan linear dari analisis regresi tersebut adalah $\mathrm{Y}=69.63-$ Q.35X, menunjukkan bahwa apabila variable jarak mengalami penambahan $1 \mathrm{~m}$ Gkan menurunkan variable kebisingan sebesar $0.35 \mathrm{~dB}$. Menurunkan variable Jarak artinya semakin dekat dengan sumber bising. Jarak berpengaruh terhadap nilai kebisingan yang dihasilkan. Semakin dekat dengan sumber bising maka nilai kebisingannya akan semakin besar, begitu juga sebaliknya apabila semakin jauh jarak dengan sumber bising maka nilai kebisingannya akan semakin berkurang.

Tingkat Bising (dB)

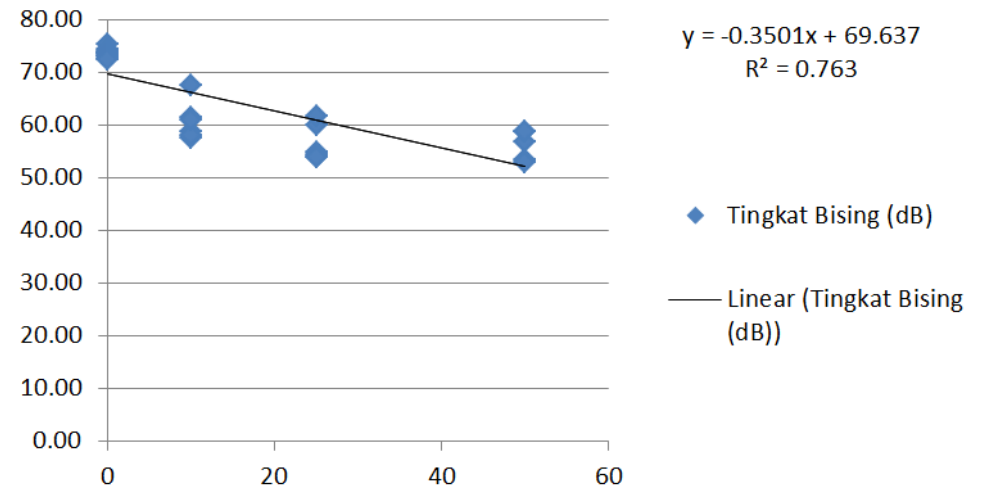

Gambar 24 Grafik persamaan regresi linear

\section{Pengaruh jarak dan waktu terhadap kebisingan}

Pengaruh jarak dan waktu terhadap kebisingan dilakukan dengan uji statistic rancangan factorial yang terdiri dari tiga faktor, yaitu waktu, jarak, dan interaksi antara jarak dan waktu. Hasil analisis tersebut dapat dilihat pada Tabel 4. 
Tabel 4 Pengaruh jarak dan waktu terhadap nilai kebisingan

$\begin{array}{ccc}\text { Faktor } & \text { df } & p \text {-value } \\ \text { Jarak } & 3 & 0.000 \\ \text { Waktu } & 2 & 0.146 \\ \text { Jarak * Waktu } & 6 & 0.051\end{array}$

Berdasarkan hasil uji rancangan factorial menunjukkan bahwa pada lokasi Perumahan IPB 1 Baranangsiang terdapat pengaruh signifikan antara jarak terhadap kebisingan. Akan tetapi, factor waktu terhadap nilai kebisingan tidak berpengaruh. Tingkat kebisingan akan menurun apabila semakin jauh dari sumber bising , hal ini disebabkan saat terdapat sumber bunyi bergetar maka gelombang bunyi \&kan merambat ke segala arah dengan menempuh jarak tertentu, melemah kemudían menghilang (Suharjanto 2012). Faktor waktu bukan factor yang signifiean dalam mempengaruhi nilai kebisingan. Waktu yang dilakukan pada waktu承bur dan kerja, pada saat jam sibuk maupun jam lenggang. Waktu tersebut berimp]ikasi pada jumlah kendaraan yang melintas di perumahan tersebut. Berikut adalah jumlah kendaraan yang melintas di Jalan Tol Jagorawi, Jalan Padi, Jalan Pandu dan Jalan Sinangling Padi Ramp.

Tabel 5 Jumlah kendaraan yang melintas pada kawasan Perumahan IPB 1 Baranangsiang

\begin{tabular}{lll} 
& & \\
\hline & & \\
\hline Minggu, 31 Maret 2019 & Jumlah Kendaraan/hari & Jumlah Kendaraan/jam \\
\hline Tol Jagorawi & 60507 unit & 2521 unit \\
Padi & 32649 unit & 1360 unit \\
Pandä & 33691 unit & 1403 unit \\
Sinangling Padi Ramp & 24156 unit & 1006 unit \\
\hline Senin, 1 April 2019 & & \\
\hline Tol Jagorawi & 53701 unit & 2237 unit \\
Padi & 34051 unit & 1418 unit \\
Pandu & 40860 unit & 1702 unit \\
Sinangling Padi Ramp & 25620 unit & 1067 unit \\
\hline Rabu, 3 April 2019 & & 2427 unit \\
Tol Jagorawi & 58255 unit & 1418 unit \\
Padi & 34051 unit & 1702 unit \\
Pandu & 40860 unit & 1067 unit \\
Sinangling Padi Ramp & 25620 unit &
\end{tabular}

Berdasarkan data yang diperoleh dari Jasamarga (2020), jumlah kendaraan yang melintas di Jalan Tol Jagorawi pada hari Minggu lebih banyak daripada jumlânkendaraan pada hari Senin dan Rabu. Pada hari Minggu, jumlah kendaraan yang melintas paling banyak terjadi pada pukul 11.00 WIB (2 235 unit) dan 16.00 WIB (2 470 unit). Pada hari Senin, jumlah kendaraan yang melintas paling banyak terjadipada pukul 16.00 WIB (1 515 unit) dan 18.00 WIB (2 195 unit). Selain itu, pada hari Rabu jumlah kendaraan yang melintas paling banyak terjadi pada pukul 12.000WIB (2 656 unit) dan 17.00 WIB (2 304 unit). Adapun data yang diperoleh dari Dinas Perhubungan Kota Bogor (2019), jumlah kendaraan yang melintas di 
Jalan Padi, Jalan Pandu, dan Jalan Sinangling Ramp pada hari Minggu lebih sedikit dibandingkan pada hari Senin dan Rabu.

Pada saat hari libur jumlah kendaraan yang melintas pada kawasan perumahan IPB 1 Baranangsiang lebih sedikit, baik waktu sibuk maupun lenggang. Lain halnya dengan jumlah kendaraan yang melintas pada J1. Tol Jagorawi memang lebih padat pada hari libur dibandingkan hari kerja dikarenakan pada hari libur banyak masyarakat dari luar Kota Bogor berwisata ke Kota Bogor atau ke puncak. Pada waktu libur warga perumahan lebih banyak menghabiskan waktu di dalam rumah/istirahat, sedangkan pada hari kerja kendaraan yang melintas perumahan tersebut semakin banyak, pada saat jam sibuk maupun lenggang, karena banyak warga di perumahan tersebut pergi melakukan aktivitas di luar perumahan dan banyak pendatang yang memasuki perumahan tersebut fanya untuk menuju sekolah yang berada di dalam perumahan tersebut. Dari हैंenjelasan tersebut dapat diketahui factor waktu tidak mempengaruhi nilai bising, melainkan faktor jumlah kendaraan melintas yang mempengaruhi nilai bising.

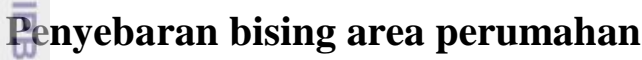

Perumahan IPB I Baranangsiang terletak diantara dua sumber bising, yaitu Jalan Padi - jalan Tol Jagorawi di sebelah utara, serta Jalan Sinangling Padi Ramp Jalan Pandu Raya di sebelah timur. Adapun sumber bising lainnya berasal dari bagian selatan dan barat dari perumahan, yaitu sekolah SD Islam Terpadu Al Khairiyah, lapangan futsal, serta permukiman lain. Pola penyebaran bising untuk sumber di sebelah utara dan timur ditunjukkan pada Gambar 25. Pola penyebaran bising dibuat dengan menggunakan software Golden Surfer.

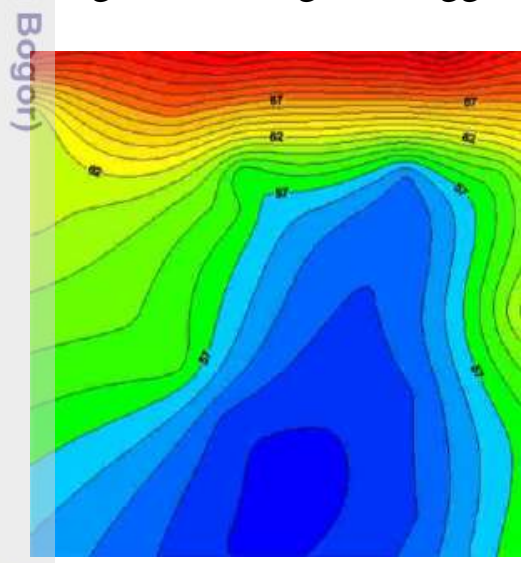

(a)

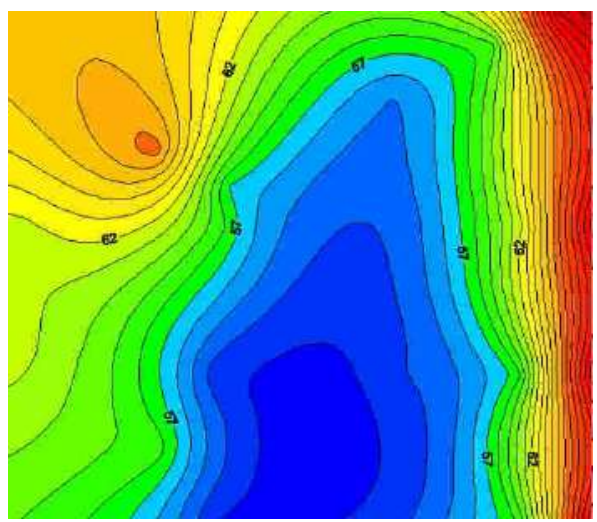

(b)

Gambar 25 Pola penyebaran bising pada sumber bising (a) utara dan (b) timur

Sumber bising yang berasal dari jalan Tol Jagorawi tidak terlalu dominan dikarenakan terhalang oleh barrier tanaman, sehingga sumber bising dari Jalan Padi akan lebih dominan untuk sumber bising di bagian utara. Sumber suara dari kendaraan yang melintas di Jalan Padi akan menyebar dan dipantulkan oleh barrier tanaman dan rumah-rumah yang ada di pinggir jalan, sehingga rumahFumah yang terletak di bagian dalam tidak merasakan bising yang tinggi karena terhalang oleh rumah-rumah yang di depannya.

Pada sumber bagian timur terlihat bahwa terdapat kontur berwarna oranye. Hal ini dikarenakan pada kontur tersebut juga terdapat pengaruh sumber suara yang berasal dari bagian utara. Pada bagian timur, sumber bising berasal dari dua 
jalan yang berada pada ketinggian level yang berbeda. Terdapat pula barisan pohon yang dapat berfungsi sebagai barrier diantara kedua jalan tersebut. Penyusunan barrier pohon tersebut tidak rapat sehingga gelombang suara dapat menyebar diantara pohon-pohon tersebut. Gelombang suara yang berasal dari kendaraan di jalan atas akan merambat ke segala arah dan memantul kearah yang tidak beraturan apabila terdapat barrier, namun apabila terdapat barrier yang tidak rapat, maka gelombang suara akan menyebar hingga sampai ke jalan di bawahnya. Begitu pula dengan sumber suara yang berasal dari jalan bawah, gelombang suara yang berasal dari kendaraan yang melintas di bagian jalan bawah dan jalan atas akan menyebar ke segala arah, kemudian suara dipantulkan melalui barrie $\bar{r}$ dinding rumah, tanaman, dan gundukan tanah. Oleh karena itu, tingkat tekană bising yang dihasilkan dari jalan bawah akan semakin tinggi karena berasaf dari jalan atas dan jalan bawah itu sendiri. Gambar 26 menunjukkan peta sebaraft kebisingan pada area Perumahan IPB I Baranangsiang dengan menggunakan software golden surfer.

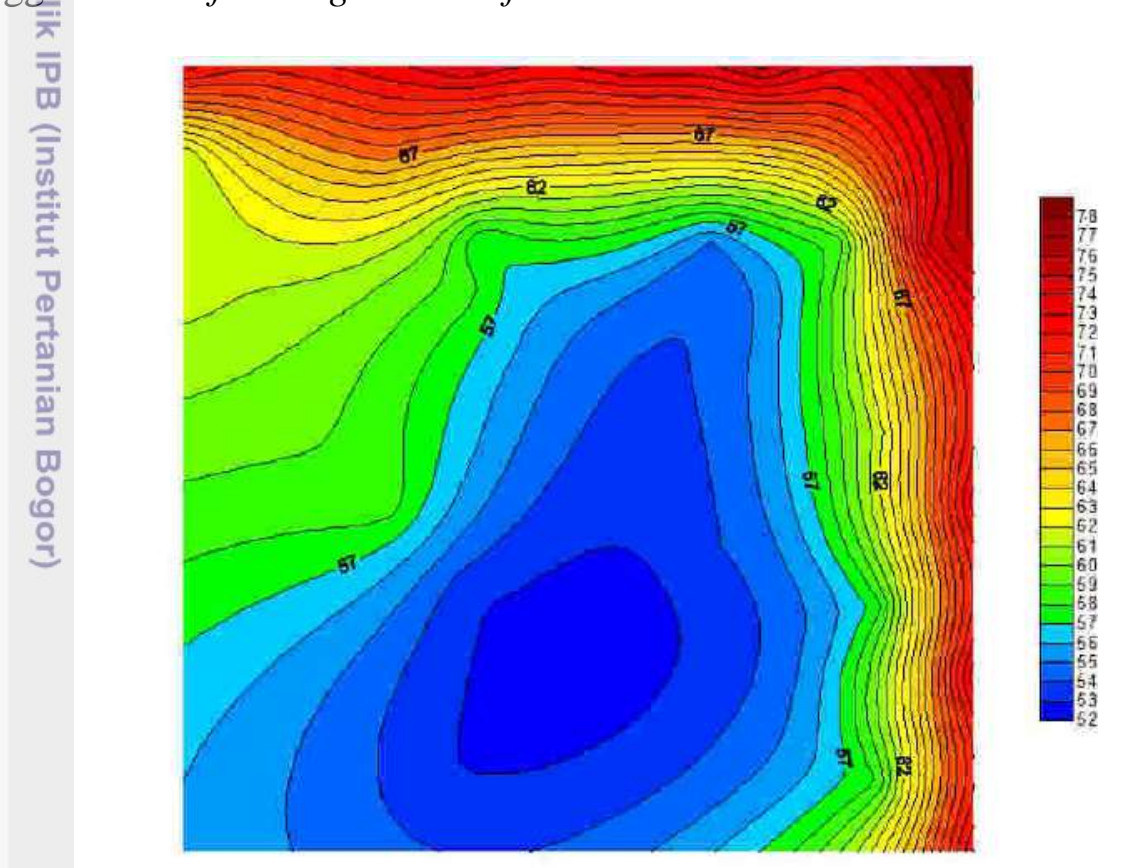

Gambar 26 Peta sebaran bising Perumahan IPB I Baranangsiang

Pada sumber di bagian utara dan timur terlihat bahwa warna kontur yang dekat dengan sumber bising berwarna merah tua, sedangkan kontur yang jauh dari sumber suara berwarna biru. Hal ini terbukti bahwa semakin jauh dari sumber suara maka tingkat kebisingan juga semakin berkurang.

\section{Persepsi dan Preferensi}

\section{Persepsi gangguan kebisingan}

Persepsi merupakan aktivitas merasakan, menginterpretasikan, dan memahrami objek baik fisik maupun social (Walgito 1981). Persepsi manusia memiliki perbedaan sudut pandang dalam penginderaan yang mempersepsikan sesuatu yang akan mempengaruhi tindakan manusia. Persepsi penduduk 
digunakan untuk mengetahui sikap penduduk terhadap gangguan kebisingan di lingkungan perumahan IPB Baranangsiang 1. Pada jarak rumah $\leq 10 \mathrm{~m}$ didapatkan tingkat kebisingan rata-rata adalah $62.37 \mathrm{~dB}$, dimana sudah melebihi baku mutu tingkat kebisingan.

Pada penelitian ini, hasil persepsi dibagi menjadi 3 kelompok, yaitu responden yang tinggal di jarak $\leq 10 \mathrm{~m}$, responden yang tinggal di jarak $25 \mathrm{~m}$, dan responden yang tinggal di jarak $50 \mathrm{~m}$. Dari ketiga kelompok responden tersebut dapat diketahui perbandingan gangguan kebisingan yang mereka rasakan selama tinggal di perumahan tersebut berdasarkan jarak rumah dari sumber bising. Rebisingan dapat menyebabkan gangguan secara fisiologi, psikologi, dan komunikasi. Gangguan secara fisiologis dapat berupa gangguan kardiovaskular, sakit kepala, cepat lelah (Chun song dan Tkebuchava 2019), dan tinnitus (Manohar et al 2016). Tinnitus merupakan sensasi suara seperti berdengung tanpa adlanya sumber suara eksternal (WHO 2015). Gangguan psikologis dapat berupa mengganggu konsentrasi, tidak nyaman, cepat marah (Herawati P 2016), dan terganggu saat tidur (Tiesler et al 2013). Gangguan komunikasi dapat berupa harus berbicara keras, sulit memahami suara saat berbicara, dan sulit mengartikan penyampaian lawan bicara. Seseorang yang mengalami gangguan pendengaran akkan kehilangan peluang untuk memahami instruksi yang diberikan secara verbal đan kesulitan melakukan asosiasi antara bunyi dan huruf (Yulianto A 2013).

Tabel 6 Persepsi penduduk yang tinggal di jarak $\leq 10 \mathrm{~m}$

\begin{tabular}{|c|c|c|c|c|c|c|}
\hline \multirow{2}{*}{ 尝o } & \multirow{2}{*}{ Pernyataan } & \multicolumn{5}{|c|}{ Tanggapan (\%) } \\
\hline & & STS & $\mathrm{TS}$ & $\mathrm{R}$ & $\mathrm{S}$ & SS \\
\hline प1 & Sakit kepala/pusing & & 92.31 & & 7.69 & \\
\hline (2) & Telinga berdengung/tinnitus & & 92.31 & 7.69 & & \\
\hline 3 & Cepat lelah & & 92.31 & 7.69 & & \\
\hline 4 & Mengganggu konsentrasi & & 30.77 & 7.69 & 38.46 & 23.08 \\
\hline 5 & Tidak nyaman & & 7.69 & & 53.85 & 38.46 \\
\hline 6 & Mudah marah/emosi & & 69.23 & 7.69 & & 23.08 \\
\hline 7 & Mengganggu saat tidur & & 7.69 & & 30.77 & 61.54 \\
\hline 8 & Harus berbicara keras & & 30.77 & 7.69 & 61.54 & \\
\hline 9 & $\begin{array}{l}\text { Sulit memahami suara saat } \\
\text { berbicara }\end{array}$ & & 76.92 & 7.69 & 15.38 & \\
\hline 10 & $\begin{array}{l}\text { Sulit mengartikan penyampaian } \\
\text { lawan bicara }\end{array}$ & & 84.62 & 7.69 & 7.69 & \\
\hline
\end{tabular}

Keterangan:

STS = sangat tidak setuju; $\mathrm{TS}$ = tidak setuju, $\mathrm{R}=$ ragu-ragu, $\mathrm{S}=$ setuju, $\mathrm{SS}=$ sangat setuju. (a)

Berdasarkan Tabel 6 diketahui penduduk perumahan IPB 1 Baranangsiang dengan jarak tinggal $\leq 10 \mathrm{~m}$ menjawab setuju mengenai gangguan kebisingan harus berbicara keras, mengganggu konsentrasi, dan tidak nyaman. Sementara itu, Sebanyak $61.54 \%$ penduduk menjawab sangat setuju pada gangguan saat tidur. 
Tabel 7 Persepsi penduduk yang tinggal di jarak $25 \mathrm{~m}$

\begin{tabular}{|c|c|c|c|c|c|c|}
\hline \multirow{2}{*}{ No } & \multirow{2}{*}{ Pernyataan } & \multicolumn{5}{|c|}{ Tanggapan (\%) } \\
\hline & & STS & TS & $\mathrm{R}$ & $\mathrm{S}$ & SS \\
\hline 1 & Sakit kepala/pusing & & 100 & & & \\
\hline 2 & Telinga berdengung/tinnitus & & 90 & & 10 & \\
\hline 3 & Cepat lelah & & 100 & & & \\
\hline 4 & Mengganggu konsentrasi & & 40 & & 60 & \\
\hline 5 & Tidak nyaman & & 30 & & 70 & 10 \\
\hline 6 & Mudah marah/emosi & & 80 & & 20 & \\
\hline 7 & Mengganggu saat tidur & & 60 & & 40 & \\
\hline 8 & farus berbicara keras & & 70 & & 20 & 10 \\
\hline 9 & $\begin{array}{l}\text { Sylit memahami suara saat } \\
\text { bêrbicara }\end{array}$ & & 80 & & 10 & 10 \\
\hline 10 & $\begin{array}{l}\text { Sulit mengartikan penyampaian } \\
\text { läwan bicara }\end{array}$ & & 80 & & 20 & \\
\hline
\end{tabular}

Keterangan:

STS = sangat tidak setuju; TS = tidak setuju, $\mathrm{R}=$ ragu-ragu, $\mathrm{S}=$ setuju, $\mathrm{SS}=$ sangat setuju. $\underset{\overline{5}}{\overline{\bar{S}}}$

Pada jarak $25 \mathrm{~m}$ diketahui rata-rata kebisingan juga melebihi baku mutu tingkat kebisiñgan untuk kawasan pemukiman dan perumahan yaitu mencapai $56.46 \mathrm{~dB}$. Pada Tabel 7 menunjukkan persepsi penduduk menjawab setuju untuk gangguan kebising an yang mereka rasakan berupa tidak nyaman (70\%), dan mengganggu konsentrasi $(60 \%)$.

Tabel $\stackrel{3}{8}$ Persepsi penduduk yang tinggal di jarak $50 \mathrm{~m}$

\begin{tabular}{|c|c|c|c|c|c|c|}
\hline \multirow{2}{*}{ No } & \multirow{2}{*}{ Pernyataan } & \multicolumn{5}{|c|}{ Tanggapan (\%) } \\
\hline & & STS & TS & $\mathrm{R}$ & $S$ & SS \\
\hline 1 & Sakit kepala/pusing & & 100 & & & \\
\hline 2 & Telinga berdengung/tinnitus & & 100 & & & \\
\hline 3 & Cepat lelah & & 100 & & & \\
\hline 4 & Mengganggu konsentrasi & & 57.14 & & 14.29 & 28.57 \\
\hline 5 & Tidak nyaman & & 28.57 & & 71.43 & \\
\hline 6 & Mudah marah/emosi & & 71.43 & & & 28.57 \\
\hline 7 & Mengganggu saat tidur & & 42.86 & & 28.57 & 28.57 \\
\hline 8 & Harus berbicara keras & & 71.43 & & 28.57 & \\
\hline 9 & $\begin{array}{l}\text { Sylit memahami suara saat } \\
\text { berbicara }\end{array}$ & & 85.71 & & 14.29 & \\
\hline 10 & $\begin{array}{l}\text { Sulit mengartikan penyampaian } \\
\text { âwan bicara }\end{array}$ & & 85.71 & & 14.29 & \\
\hline
\end{tabular}

Keterangan:

$\mathrm{STS}=$ sangat tidak setuju; $\mathrm{TS}=$ tidak setuju, $\mathrm{R}=$ ragu-ragu, $\mathrm{S}=$ setuju, $\mathrm{SS}=$ sangat setuju.

Pada jarak 50 m diketahui rata-rata kebisingan mencapai $56.10 \mathrm{~dB}$. Pada Tabel 8 menunjukkan persepsi penduduk menjawab setuju pada gangguan kebisingan tidak nyaman $(71.43 \%)$.

Dari hasil perhitungan persepsi diatas dapat diketahui bahwa sebagian besar penduduk yang tinggal di jarak $\leq 10 \mathrm{~m}, 25 \mathrm{~m}$ dan $50 \mathrm{~m}$ merasakan gangguan kebisingan secara psikologis dan komunikasi, yang berupa mengganggu 
konsentrasi, merasa tidak nyaman, mengganggu saat tidur/istirahat dan berbicara keras. Pernyataan tersebut didukung dengan hasil penelitian yang dilakukan oleh Anangga et al (2015) bahwa kebisingan dapat menimbulkan gangguan pendengaran, kehamilan, pertumbuhan bayi, gangguan komunikasi, gangguan istirahat, gangguan tidur, gangguan mental, ketidaknyamanan, dan juga gangguan aktivitas sehari-hari. Adapun penelitian yang dilakukan oleh Herawati (2016) menyatakan bahwa kebisingan juga menyebabkan gangguan psikologis dan gangguan fisiologis. Gangguan psikologis diantaranya seperti tidak nyaman, kurang konsentrasi, dan cepat marah, sedangkan gangguan fisiologis dapat berupa peredaran darah terganggu dan denyut jantung bertambah. Perbedaan persepsi penduduk dapat disebabkan oleh perbedaan karakteristik responden. Selain itu, pernyataan setiap responden mengenai gangguan kebisingan juga bersifat subjektif.

\section{Bistribusi responden mengenai gangguan kebisingan pada masing-masing tîtik pengukuran}

Pengukuran bising menggunakan alat Sound Level Meter (SLM) selama 16 jam pada 18 titik dari 27 titik, yang mewakili keseluruhan responden yang terkena dampak bising. Adapun hasil pengukuran intersitas bising pada 18 titik yang đicantumkan pada Tabel 9.

Thabel 9 Hasil pengukuran intensitas kebisingan 18 titik pengukuran

\begin{tabular}{ccccc} 
Titik & $\begin{array}{c}\text { Jarak } \\
\text { rumah }(\mathrm{m})\end{array}$ & $\begin{array}{c}\text { Tingkat bising } \\
(\mathrm{dB})\end{array}$ & $\begin{array}{c}\text { Nilai ambang } \\
\text { batas }(\mathrm{dB})\end{array}$ \\
\hline $\begin{array}{c}\text { pengukuran } \\
\text { No }\end{array}$ & Titik 6 & 10 & 58.70 & \\
4 & Titik 7 & 25 & 54.96 & \\
5 & Titik 8 & 50 & 56.90 & \\
6 & Titik 10 & 10 & 61.38 & \\
7 & Titik 11 & 25 & 54.43 & \\
8 & Titik 12 & 50 & 58.67 & \\
9 & Titik 15 & 10 & 57.46 & \\
10 & Titik 16 & 50 & 53.98 & \\
11 & Titik 18 & 10 & 53.35 & \\
12 & Titik 19 & 25 & 58.03 & \\
13 & Titik 20 & 50 & 53.87 & \\
14 & Titik 22 & 10 & 52.95 & \\
15 & Titik 23 & 25 & 67.51 & \\
16 & Titik 24 & 50 & 59.90 & \\
17 & Titik 25 & 0 & 58.63 & \\
\hline 18 & Titik 26 & 10 & 72.47 & \\
\hline
\end{tabular}

Berdasarkan Tabel 9 diketahui dari 18 titik pengukuran, intensitas bising di 12 titik pengukuran telah melebihi nilai ambang batas $>55 \mathrm{~dB}$ yang berpotensi mengakibatkan gangguan pendengaran, sedangkan 6 titik lainnya tidak melebihi nilai ambang batas $<55 \mathrm{~dB}$. 
Tingkat kebisingan di Perumahan IPB 1 Baranangsiang sudah melebihi nilai batas ambang yang diperkenankan dan jika dibiarkan terus menerus dapat menimbulkan kerugian pada penduduk perumahan. Distribusi responden pada 18 titik dan jumlah responden yang mengalami gangguan kebisingan secara fisiologi yang dialami ditunjukkan pada Tabel 10.

Tabel 10 Distribusi responden yang mengalami gangguan fisiologi

\begin{tabular}{|c|c|c|c|c|c|c|c|}
\hline \multirow{2}{*}{$\begin{array}{l}\text { Titik } \\
\text { ukurin }\end{array}$} & \multirow{2}{*}{$\begin{array}{l}\text { Jarak } \\
\text { rumah } \\
(\mathrm{m})\end{array}$} & \multirow{2}{*}{$\begin{array}{c}\text { Tingkat } \\
\text { bising } \\
\text { (dB) }\end{array}$} & \multicolumn{2}{|c|}{$\begin{array}{l}\text { Jumlah } \\
\text { responden }\end{array}$} & \multicolumn{3}{|c|}{$\begin{array}{c}\text { Jumlah responden yang mengalami } \\
\text { gangguan fisiologi }\end{array}$} \\
\hline & & & $\mathrm{n}$ & $\%$ & Sakit kepala & Tinnitus & Cepat lelah \\
\hline Titik 6 & 10 & 58.70 & 4 & 13.3 & 0 & 0 & 0 \\
\hline Titik 7 & 25 & 54.96 & 2 & 6.7 & 0 & 0 & 0 \\
\hline Titik-8 & 50 & 56.90 & 1 & 3.3 & 0 & 0 & 0 \\
\hline Titik 10 & 10 & 61.38 & 2 & 6.7 & 0 & 0 & 0 \\
\hline Titik 1 & 25 & 54.43 & 2 & 6.7 & 0 & 0 & 0 \\
\hline Titik 2 & 50 & 58.67 & 1 & 3.3 & 0 & 0 & 0 \\
\hline Titik 4 & 10 & 57.46 & 2 & 6.7 & 0 & 0 & 0 \\
\hline Titik 15 & 25 & 53.98 & 2 & 6.7 & 0 & 0 & 0 \\
\hline Titik 16 & 50 & 53.35 & 2 & 6.7 & 0 & 0 & 0 \\
\hline Titik & 10 & 58.03 & 2 & 6.7 & 0 & 0 & 0 \\
\hline Titik 19 & 25 & 53.87 & 2 & 6.7 & 0 & 1 & 0 \\
\hline Titik 20 & 50 & 52.95 & 2 & 6.7 & 0 & 0 & 0 \\
\hline Titik 22 & 10 & 67.51 & 1 & 3.3 & 1 & 0 & 0 \\
\hline Titik23 & 25 & 59.90 & 1 & 3.3 & 0 & 0 & 0 \\
\hline Titik24 & 50 & 58.63 & 1 & 3.3 & 0 & 0 & 0 \\
\hline Titik25 & 0 & 72.47 & 1 & 3.3 & 0 & 0 & 0 \\
\hline Titik 26 & 10 & 61.02 & 1 & 3.3 & 0 & 0 & 0 \\
\hline \multirow[t]{2}{*}{ Titik 27} & 25 & 61.60 & 1 & 3.3 & 0 & 0 & 0 \\
\hline & Jumla & & 30 & 100 & 1 & 1 & 0 \\
\hline
\end{tabular}

Dari Tabel 10, dapat dilihat bahwa responden titik 22 menerima intensitas bising tinggi kedua, yaitu $67.51 \mathrm{~dB}$ mengalami gangguan fisiologis berupa sakit kepala. Hal ini menunjukkan semakin tinggi intensitas bising, maka semakin besar dampak gangguan kebisingan yang diakibatkan. Menurut Chun Song dan Thebuchava (2019), kebisingingan tidak hanya menyebabkan masalah kesehatan seperti kelelahan, stress, cepat marah, sakit kepala, dan insomnia, tetapi juga dapat membahayakan system kardiovaskular dan menyebabkan hipertensi, penyakit jantung, aritmia (atrium fibrilasi) dan stroke, serta ketidakseimbangan otak dan metabolisme seperti obesitas, diabetes, kanker, gangguan kognitif, dan penyakit mentałsetelah paparan jangka panjang.

Titik 25 memiliki tingkat bising tertinggi, yaitu $72.47 \mathrm{~dB}$, namun responden tidak merasakan dampak fisiologis akibat bising. Hal ini dikarenakan tipe rumah responden 25 adalah 2 tingkat dan memiliki banyak tanaman di halaman rumahnya, sedangkan tipe rumah responden 22 adalah 1 tingkat dan tidak terlalu banyak tanaman di halaman rumahnya. Dinding rumah dapat dijadikan sebagai barrier kebisingan. Tipe rumah 2 tingkat memiliki barrier yang lebih baik dibandingkan dengan tipe rumah 1 tingkat. Hal ini sesuai dengan pernyataan dari Umiati (2012) bahwa pagar tembok setinggi 2 meter dapat menurunkan tingkat 
kebisingan di halaman rumah sebesar $9.02 \mathrm{~dB}$. Selain itu, penempatan beberapa tanaman di halaman rumah dapat berfungsi sebagai barrier pereduksi bising. Menurut penelitian yang dilakukan oleh Kalansuriya (2009), barrier vegetasi dapat mereduksi tingkat bising sebanyak $4 \mathrm{~dB}-5 \mathrm{~dB}$, dengan ketebalan tanaman $1.5 \mathrm{~m}$.

Selain gangguan fisiologi, gangguan akibat kebisingan lainnya adalah gangguan psikologi. Distribusi responden dan jumlah responden yang mengalami gangguan psikologi ditunjukkan pada Tabel 11.

Tabel 11 Distribusi responden yang mengalami gangguan psikologi

\begin{tabular}{|c|c|c|c|c|c|c|c|c|}
\hline \multirow{2}{*}{ 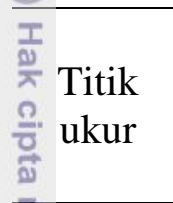 } & \multirow{2}{*}{$\begin{array}{l}\text { Jarak } \\
\text { rumah } \\
(\mathrm{m})\end{array}$} & \multirow{2}{*}{$\begin{array}{c}\text { Tingkat } \\
\text { bising } \\
\text { (dB) }\end{array}$} & \multicolumn{2}{|c|}{$\begin{array}{l}\text { Jumlah } \\
\text { responden }\end{array}$} & \multicolumn{4}{|c|}{$\begin{array}{l}\text { Jumlah responden yang mengalami } \\
\text { gangguan psikologi }\end{array}$} \\
\hline & & & $\mathrm{n}$ & $\%$ & $\begin{array}{c}\text { Ganggu } \\
\text { konsentrasi }\end{array}$ & $\begin{array}{l}\text { Tidak } \\
\text { nyaman }\end{array}$ & $\begin{array}{l}\text { Mudah } \\
\text { marah }\end{array}$ & $\begin{array}{l}\text { Ganggu } \\
\text { saat tidur }\end{array}$ \\
\hline Titik 6 & 10 & 58.70 & 4 & 13.3 & 4 & 4 & 2 & 4 \\
\hline Titik 7 & 25 & 54.96 & 2 & 6.7 & 2 & 2 & 0 & 2 \\
\hline gitik 8 & 50 & 56.90 & 1 & 3.3 & 1 & 1 & 1 & 1 \\
\hline Fitik 10 & 10 & 61.38 & 2 & 6.7 & 2 & 2 & 0 & 2 \\
\hline क्ञ़्रitik 11 & 25 & 54.43 & 2 & 6.7 & 1 & 2 & 0 & 1 \\
\hline Titik 12 & 50 & 58.67 & 1 & 3.3 & 1 & 1 & 0 & 1 \\
\hline Titik 14 & 10 & 57.46 & 2 & 6.7 & 2 & 2 & 1 & 2 \\
\hline Titik 15 & 25 & 53.98 & 2 & 6.7 & 1 & 1 & 0 & 1 \\
\hline Jitik 16 & 50 & 53.35 & 2 & 6.7 & 1 & 1 & 0 & 1 \\
\hline JTitik 18 & 10 & 58.03 & 2 & 6.7 & 0 & 2 & 0 & 2 \\
\hline प्रTitik 19 & 25 & 53.87 & 2 & 6.7 & 1 & 2 & 2 & 2 \\
\hline @itik 20 & 50 & 52.95 & 2 & 6.7 & 0 & 2 & 0 & 0 \\
\hline Titik 22 & 10 & 67.51 & 1 & 3.3 & 0 & 1 & 0 & 1 \\
\hline Titik 23 & 25 & 59.90 & 1 & 3.3 & 1 & 1 & 1 & 1 \\
\hline Titik 24 & 50 & 58.63 & 1 & 3.3 & 0 & 0 & 1 & 1 \\
\hline Titik 25 & 0 & 72.47 & 1 & 3.3 & 0 & 1 & 0 & 1 \\
\hline Titik 26 & 10 & 61.02 & 1 & 3.3 & 0 & 0 & 0 & 0 \\
\hline Titik 27 & 25 & 61.60 & 1 & 3.3 & 0 & 0 & 0 & 1 \\
\hline & Jumlah & & 30 & 100 & 17 & 25 & 8 & 24 \\
\hline
\end{tabular}

Pada Tabel 11 menunjukkan bahwa sebagian besar responden mengalami gangguan psikologi akibat bising. Hampir semua responden yang tinggal di jarak g. $\mathrm{m}$ dan $10 \mathrm{~m}$ sebagian besar mengalami gangguan psikologi. Dengan jenis (gangguan yang paling banyak dialami adalah tidak nyaman, kemudian terganggu Satat tidur, lalu konsentrasi terganggu, dan disusul dengan mudah marah. Penelitian yang dilakukan oleh Kristiyanto et al (2014) juga menyatakan bahwa kebisingan dapat mempengaruhi gangguan psikologis seperti tidak nyaman, kurang konsentrasi, susah tidur, cepat marah, kejengkelan, dan kebingungan. Akan tetapi, responden 26, yang tinggal di jarak $10 \mathrm{~m}$, tidak mengalami gangguan. Hal ini dikarenakan lingkungan rumah responden 26 terletak diantara rumah responden 25 dan 27, dimana kedua rumah tersebut merupakan tipe rumah 2 ingkat, sehingga kedua rumah tersebut dengan kata lain dapat dijadikan barrier bagi responden 26. 
Pada gangguan psikologi, manusia menginterpretasikan bunyi yang ditangkapnya pada proses terakhir pendengaran. Apabila terjadi kerusakan penerimaan dipusat pendengaran dibagian otak oleh syaraf pendengaran, manusia menginterpretasikan bunyi bising tersebut sebagai kondisi yang mengancamnya. Hal ini ditandai dengan adanya gerakan/reaksi pada manusia, seperti meningkatnya hormone cortical, ketegangan meninggi, emosi bertambah, dan sebagainya (Yulianto 2013).

Gangguan akibat kebisingan lainnya adalah gangguan komunikasi. Distribusi responden dan jumlah responden yang mengalami gangguan komunikasi ditunjukkan pada Tabel 12.

Tabel ${ }^{1} 2$ Distribusi responden yang mengalami gangguan komunikasi

\begin{tabular}{|c|c|c|c|c|c|c|c|}
\hline \multirow{2}{*}{ 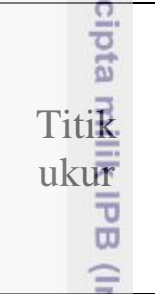 } & \multirow[b]{2}{*}{$\begin{array}{l}\text { Jarak } \\
\text { rumah } \\
(\mathrm{m})\end{array}$} & \multirow[b]{2}{*}{$\begin{array}{l}\text { Tingkat } \\
\text { bising } \\
\text { (dB) }\end{array}$} & \multicolumn{2}{|c|}{$\begin{array}{l}\text { Jumlah } \\
\text { responden }\end{array}$} & \multicolumn{3}{|c|}{$\begin{array}{l}\text { Jumlah responden yang mengalami } \\
\text { gangguan komunikasi }\end{array}$} \\
\hline & & & $\mathrm{n}$ & $\%$ & $\begin{array}{l}\text { Bicara } \\
\text { keras }\end{array}$ & $\begin{array}{c}\text { Sulit } \\
\text { memahami } \\
\text { suara }\end{array}$ & $\begin{array}{c}\text { Sulit } \\
\text { mengartikan } \\
\text { penyampaian } \\
\text { lawan bicara }\end{array}$ \\
\hline Titik 6 & 10 & 58.70 & 4 & 13.3 & 4 & 2 & 0 \\
\hline Titik弱 & 25 & 54.96 & 2 & 6.7 & 1 & 0 & 0 \\
\hline Titik 8 & 50 & 56.90 & 1 & 3.3 & 1 & 0 & 1 \\
\hline Titik 10 & 10 & 61.38 & 2 & 6.7 & 2 & 0 & 1 \\
\hline Titik当1 & 25 & 54.43 & 2 & 6.7 & 0 & 0 & 0 \\
\hline Titik 12 & 50 & 58.67 & 1 & 3.3 & 0 & 0 & 0 \\
\hline Titikg4 & 10 & 57.46 & 2 & 6.7 & 2 & 0 & 0 \\
\hline Titikğ5 & 25 & 53.98 & 2 & 6.7 & 0 & 0 & 1 \\
\hline Titik 76 & 50 & 53.35 & 2 & 6.7 & 1 & 0 & 0 \\
\hline Titik 18 & 10 & 58.03 & 2 & 6.7 & 0 & 0 & 0 \\
\hline Titik 19 & 25 & 53.87 & 2 & 6.7 & 1 & 1 & 0 \\
\hline Titik 20 & 50 & 52.95 & 2 & 6.7 & 0 & 0 & 0 \\
\hline Titik 22 & 10 & 67.51 & 1 & 3.3 & - & 0 & 0 \\
\hline Titik 23 & 25 & 59.90 & 1 & 3.3 & 1 & 1 & 1 \\
\hline Titik 24 & 50 & 58.63 & 1 & 3.3 & 0 & 1 & 0 \\
\hline Titik 25 & 0 & 72.47 & 1 & 3.3 & 0 & 0 & 0 \\
\hline Titik 26 & 10 & 61.02 & 1 & 3.3 & 0 & 0 & 0 \\
\hline Titik 27 & 25 & 61.60 & 1 & 3.3 & 0 & 0 & 0 \\
\hline W & Jumlah & & 30 & 100 & 13 & 5 & 4 \\
\hline
\end{tabular}

Gangguan komunikasi yang dirasakan oleh sebagian besar responden adalah harus berbicara keras. Titik 19 memiliki tingkat bising yang lebih rendah daripada titik 18, namun responden titik 19 mengalami gangguan kebisingan berupa berbicara keras dikarenakan pada lingkungan rumah responden tersebut terdapat hewan peliharaan dalam jumlah banyak, sehingga pada saat komunikasi responden tersebut harus berbicara keras agar lawan bicara terdengar dan suaranya tidak lebih kecil dari suara hewan peliharaannya.

Seseorang yang mengalami gangguan pendengaran akan kesulitan dalam memahami instruksi secara verbal, merasa cepat lelah karena memerlukan tenaga ekstra dalam mendengarkan penjelasan dari lawan bicara, dan kesulitan 
melakukan asosiasi antara bunyi dan huruf, khususnya pada saat di luar ruangan. Kemampuan mengingat agak terganggu, selanjutnya kewaspadaan terhadap bahaya kurang, prestasi menurun, serta lebih mengembangkan dominasi indera visual dan kinestetik dalam menyerap penyampaian yang diberikan rekan kerja. Dari proses perilaku, seseorang yang mengalami gangguan pendengaran akan sering dipersepsikan sebagai seseorang yang canggung dan kurang peka terhadap isyarat percakapan yang disampaikan (Yulianto 2013).

\section{Hubungan tingkat bising dengan gangguan kebisingan penduduk}

Dalam penelitian ini, variable dari karakteristik responden yang digunakan adalah variable intensitas kebisingan. Variabel ini digunkaan untuk menganalisis hubungan intensitas kebisingan dengan gangguan kebisingan yang dirasakan, baik secara fisiologi, psikologi, dan komunikasi. Pada Tabel 13 menunjukkan fiubungan intensitas bising dengan gangguan bising secara fisiologis.

Fabel 13 Hasil uji bivariate terhadap gangguan fisiologi

\begin{tabular}{|c|c|c|c|c|c|c|c|c|}
\hline \multirow{3}{*}{ 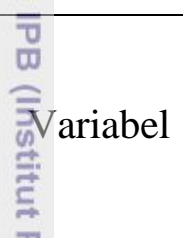 } & \multirow{2}{*}{\multicolumn{2}{|c|}{$\begin{array}{l}\text { Jumlah } \\
\text { responden }\end{array}$}} & \multicolumn{6}{|c|}{ Gangguan fisiologi } \\
\hline & & & \multicolumn{2}{|c|}{ Sakit kepala } & \multicolumn{2}{|c|}{ Tinnitus } & \multicolumn{2}{|c|}{ Cepat lelah } \\
\hline & $\mathrm{n}$ & $\%$ & $\begin{array}{c}p \\
\text { value }\end{array}$ & $\begin{array}{c}\text { koef. } \\
\text { korelasi }\end{array}$ & $\begin{array}{c}p \\
\text { value }\end{array}$ & $\begin{array}{c}\text { koef. } \\
\text { korelasi }\end{array}$ & $\begin{array}{c}p \\
\text { value }\end{array}$ & $\begin{array}{c}\text { koef. } \\
\text { korelasi }\end{array}$ \\
\hline $\begin{array}{l}\text { gkat } \\
\text { ing }\end{array}$ & 30 & 100 & 0.040 & $0.206^{*}$ & 0.464 & 0.074 & & \\
\hline
\end{tabular}

\section{Keterangan:}

*

$\stackrel{\circ}{\circ}$

Tabel 13 menunjukkan uji statistic menggunakan korelasi rank Spearman dengan Æ sebesar 0.05 , diperoleh nilai $p$ value pada gangguan sakit kepala adalah 0.040 , dengan korelasi 0.206. Hal ini menunjukkan bahwa terdapat hubungan yang signifikan antara intensitas bising dengan gangguan sakit kepala, dengan keeratan hubungan yang lemah. Pada gangguan tinnitus dan cepat lelah tidak terdapat hubungan yang signifikan dengan intensitas kebisingan. Tabel 14 menunjukkan hasil uji statistic intensitas kebisingan dengan gangguan psikologi.

Tabel 14 Hasil uji bivariate terhadap gangguan psikologi

\begin{tabular}{|c|c|c|c|c|c|c|c|c|c|c|}
\hline \multirow{3}{*}{$\begin{array}{c}\text { Variabel } \\
\frac{6}{6} \\
\frac{0}{7}\end{array}$} & \multirow{2}{*}{\multicolumn{2}{|c|}{$\begin{array}{l}\text { Jumlah } \\
\text { responden }\end{array}$}} & \multicolumn{8}{|c|}{ Gangguan psikologi } \\
\hline & & & \multicolumn{2}{|c|}{$\begin{array}{l}\text { Konsentrasi } \\
\text { terganggu }\end{array}$} & \multicolumn{2}{|c|}{$\begin{array}{c}\text { Tidak } \\
\text { nyaman }\end{array}$} & \multicolumn{2}{|c|}{$\begin{array}{l}\text { Mudah } \\
\text { marah }\end{array}$} & \multicolumn{2}{|c|}{$\begin{array}{l}\text { Terganggu saat } \\
\text { tidur }\end{array}$} \\
\hline & $\mathrm{n}$ & $\%$ & $\begin{array}{c}p \\
\text { value }\end{array}$ & $\begin{array}{l}\text { kf. } \\
\text { kor }\end{array}$ & $p$ value & $\begin{array}{c}\text { koef. } \\
\text { kor }\end{array}$ & $\begin{array}{c}p \\
\text { value }\end{array}$ & $\begin{array}{c}\text { koef. } \\
\text { kor }\end{array}$ & $\begin{array}{c}p \\
\text { value }\end{array}$ & $\begin{array}{c}\text { koef. } \\
\text { kor }\end{array}$ \\
\hline $\begin{array}{l}\text { Tingkat } \\
\text { bising }\end{array}$ & 30 & 100 & 0.410 & 0.083 & 0.000 & $0.486^{* *}$ & 0.474 & 0.072 & 0.000 & $0.421^{* *}$ \\
\hline
\end{tabular}

Hasil uji statistic pada Tabel 14 menggunakan korelasi rank Spearman dengan $\alpha$ sebesar 0.05. Dari hasil uji statistic diperoleh nilai $p$ value pada gangguan konsentrasi adalah 0.410 dengan korelasi 0.083 . Hal ini menunjukkan bahwa hubungan antara intensitas bising dengan gangguan konsentrasi tidak 
signifikan. Adapun nilai $p$ value pada gangguan tidak nyaman adalah 0.000 dengan korelasi 0.486 , hal ini menunjukkan bahwa terdapat hubungan yang signifikan antara intensitas bising dengan gangguan tidak nyaman, dengan tingkat keeratan yang cukup kuat (sedang). Untuk nilai $p$ value pada gangguan mudah marah adalah 0.474 dengan korelasi 0.072 yang menunjukkan bahwa hubungan antara intensitas bising dengan gangguan konsentrasi tidak signifikan. Selain itu, pada gangguan saat tidur diperoleh nilai $p$ value 0.000 dengan korelasi 0.421 , yang menunjukkan bahwa hubungan terdapat hubungan yang signifikan antara intensitas bising dengan gangguan saat tidur, dengan tingkat keeratan yang cukup kuat (sedang). Hubungan intensitas kebisingan dengan gangguan komunikasi ditunjukkan pada Tabel 15.

Tabel స̂5 Hasil uji bivariate terhadap gangguan komunikasi

\begin{tabular}{|c|c|c|c|c|c|c|c|c|}
\hline \multirow{3}{*}{ 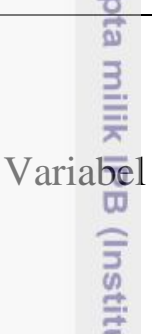 } & \multirow{2}{*}{\multicolumn{2}{|c|}{$\begin{array}{l}\text { Jumlah } \\
\text { responden }\end{array}$}} & \multicolumn{6}{|c|}{ Gangguan komunikasi } \\
\hline & & & \multicolumn{2}{|c|}{ Berbicara keras } & \multicolumn{2}{|c|}{$\begin{array}{l}\text { Sulit memahami } \\
\text { suara saat bicara }\end{array}$} & \multicolumn{2}{|c|}{$\begin{array}{c}\text { Sulit mengartikan } \\
\text { penyampaian } \\
\text { lawan bicara }\end{array}$} \\
\hline & $\mathrm{n}$ & $\%$ & $\begin{array}{c}p \\
\text { value }\end{array}$ & $\begin{array}{c}\text { kf. } \\
\text { korelasi }\end{array}$ & $\begin{array}{c}p \\
\text { value }\end{array}$ & $\begin{array}{c}\text { kf. } \\
\text { korelasi }\end{array}$ & $\begin{array}{c}p \\
\text { value }\end{array}$ & $\begin{array}{c}\text { kf. } \\
\text { korelasi }\end{array}$ \\
\hline $\begin{array}{l}\text { Tingkatt } \\
\text { bisin }\end{array}$ & 30 & 100 & 0.001 & $0.323^{* * *}$ & 0.155 & 0.143 & 0.513 & -0.066 \\
\hline
\end{tabular}

Keterangan:

**uji körelasi Spearman dengan taraf sig. 5\%

Berdasărkan hasil uji statistic pada Tabel 15 menggunakan korelasi rank spearhan, dengan $\alpha$ sebesar 0.05 , diperoleh nilai $p$ value pada gangguan berbicara keras ãdalah 0.001 dengan korelasi 0.323 . Hal ini menunjukkan bahwa terdapat hubungan signifikan antara variable intensitas bising dengan gangguan berbicara keras, dengan keeratan hubungan lemah. Selain itu, pada gangguan sulit memahami suara saat bicara dengan gangguan sulit mengartikan penyampaian lawan bicara tidak terdapat hubungan yang signifikan.

\section{Persepsi kenyamanan audial}

Hasil persepsi mengenai kenyamanan audial di lingkungan perumahan ditunjukkan pada Tabel 16.

Tabel 16 Persepsi mengenai kenyamaan audial lingkungan perumahan

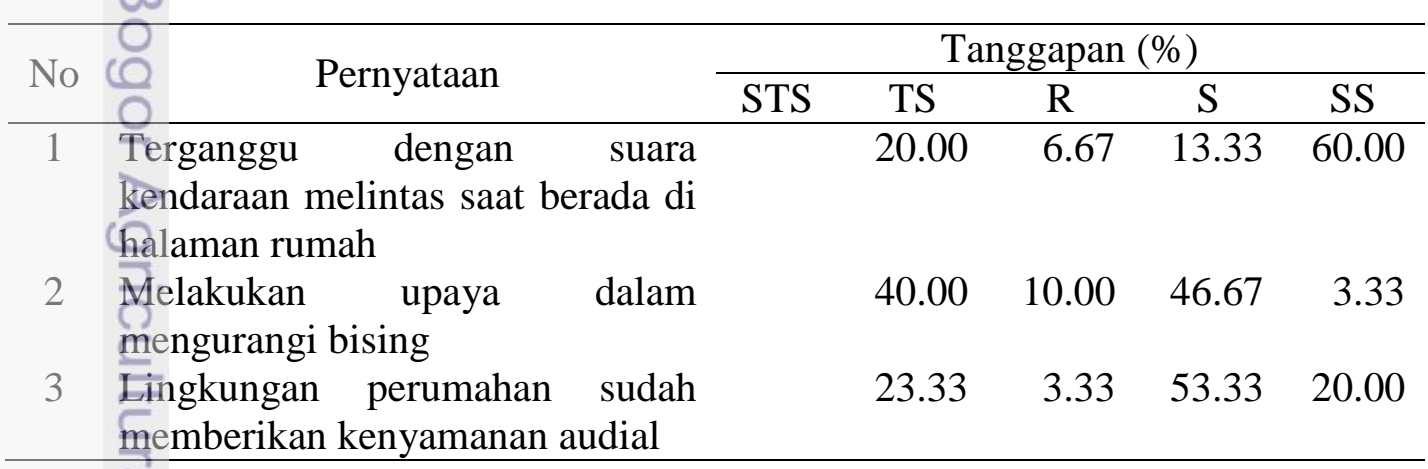

Keterangan:

STS = sangat tidak setuju; $\mathrm{TS}=$ tidak setuju, $\mathrm{R}=$ ragu-ragu, $\mathrm{S}=$ setuju, $\mathrm{SS}=$ sangat setuju. 
Dari hasil penelitian mengenai kenyamanan audial di lingkungan perumahan IPB 1 Baranangsiang, responden merasa terganggu dengan adanya suara bising dari kendaraan yang melintas saat berada di halaman rumah, dengan perolehan suara $60 \%$. Perumahan IPB 1 Baranangsiang berbatasan dengan pemukiman penduduk yang memiliki beberapa fasilitas, seperti sekolah dasar dan lapangan olahraga, sehingga banyak kendaraan yang melintas menuju ke tempat fasilitas tersebut melalui lingkungan perumahan IPB 1 Baranangsiang yang juga sebagai akses masuk. Dalam mengurangi kebisingan, warga mencoba melakukan upaya mengurangi bising memperoleh jawaban setuju sebanyak 46.67\%. Beberapa upaya yang dilakukan warga, seperti menutup pintu dan jendela rumah, memasang rambu larangan di lingkungan perumahan, serta melakukan aktivitas Fain yang dapat mengalihkan perhatian dari gangguan suara bising. Berdasarkan fabel 16 penduduk perumahan IPB 1 Baranangsiang lebih banyak menjawab setuju terhadap kenyamanan audial yang dirasakan di lingkungan perumahan IPB E.Baranangsiang $(53.33 \%)$.

Pernyataan tersebut sesuai dengan Djalante (2010) bahwa tingkat Ke bisingan dapat diterima tergantung pada berapa lama orang tersebut terpapar kebisingan. Tingkat kebisingan yang dapat ditolerir oleh seseorang tergantung pada kegiatan apa yang sedang dilakukan orang tersebut.

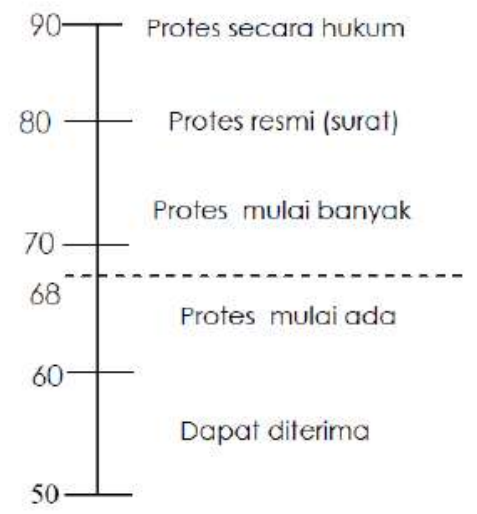

Gambar 27 Tingkat kebisingan yang ditoleransi pada kawasan pemukiman Sumber: Djalante (2010)

Berdasarkan gambar diatas tingkat kebisingan 50 - $60 \mathrm{~dB}$ masih dapat ditolerir untuk kawasan pemukiman dan perumahan. Tingkat kebisingan di dalam lingkungan perumahan IPB 1 Baranangsiang adalah $56.10-60.68 \mathrm{~dB}$, sehingga Warga perumahan masih merasa nyaman berada di lingkungan perumahan ctersebut.

\section{Preferensi penduduk dalam mengatasi kebisingan}

Dalam penelitian ini, preferensi dibagi menjadi beberapa pertanyaan antara Tain upaya pengendalian kebisingan, bentuk penataan tanaman di halaman rumah Entuk mereduksi bising, fungsi pohon yang diinginkan di halaman rumah, tipe dinding penghalang, dan kenyamanan lingkungan perumahan. Salah satu upaya pengendalian kebisingan di lingkungan perumahan dengan menggunakan barrier, barrier dapat berupa dinding penghalang maupun barrier tanaman. Gambar 28 menunjukkan hasil perhitungan preferensi penduduk terhadap upaya pengendalian kebisingan di lingkungan perumahan. 


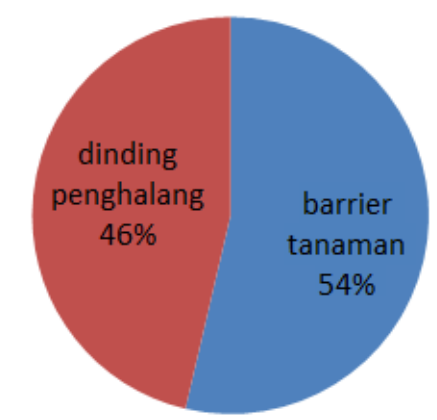

Gambar 28 Upaya pengendalian kebisingan di lingkungan perumahan

ÂTasyarakat di Perumahan IPB 1 Baranangsiang lebih memilih untuk menggunakan barrier tanaman. Tipe barrier tanaman yang paling banyak digunakan di perumahan tersebut adalah penataan berbagai macam tanaman pada halamàn rumah, namun ada juga beberapa responden yang menggunakan pagar tanaman.
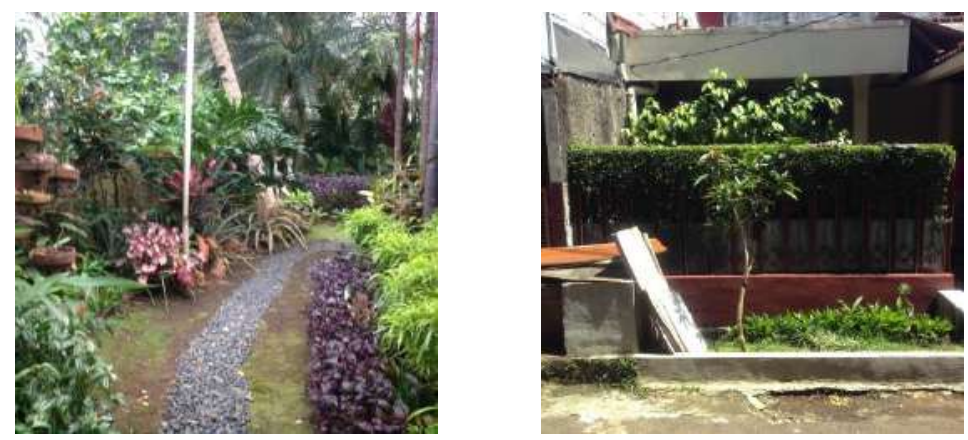

Gambar 29 Tipe barrier penataan tanaman dan pagar tanaman

Vegetasi dapat megurangi tingkat kebisingan lalu lintas, terutama di jalan-jalan sempit dengan fasad yang keras. Pagar tanaman dengan tinggi $1.5 \mathrm{~m}$ dapat mengurangi bising sekitar $4 \mathrm{~dB}$ apabila penerima berada di jarak $1 \mathrm{~m}$ dari pagar tanaman tersebut (Van Renterghem et al 2015). Penataan tanaman di halaman rumah juga dapat mengurangi tingkat kebisingan, dengan menata beberapa jenis tanaman pada halaman rumah. Hal ini juga sesuai dengan pernyataan Carpenter $e t$ al (1975) bahwa tingkat kebisingan yang dapat direduksi oleh tanaman tergantung pada kepadatan tanaman, tinggi tanaman, dan lebat penanaman.

Pola penataan tanaman pada halaman rumah dapat dikelompokkan menjadi 3 (tiga), yaitu bergerombol (rapat dan kompak), menyebar, dan berbentuk jalur. Bentuk bergerombol dapat diartikan sebagai komunitas tanaman terkonsentrasi di suatu tempat. Bentuk menyebar merupakan komunitas tanaman tumbuh menyebar beruparrumpun atau gerombol kecil, sedangkan untuk bentuk jalur adalah bentuk komunitas tanamannya tumbuh mengikuti jalur, seperti jalan dan saluran. Menfret preferensi responden, mereka menyukai penataan tanaman pada halaman rumah ditunjukkan pada Gambar 30. 


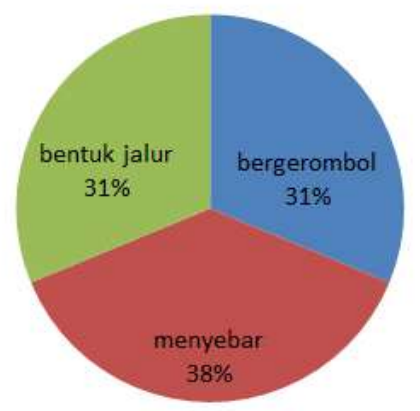

Gambar 30 Penataan tanaman pada halaman rumah untuk mereduksi bising
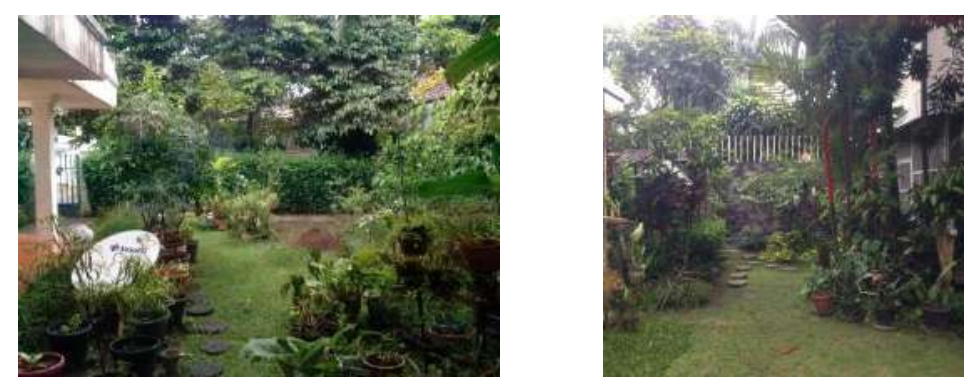

Gambar 31 Pola penataan tanaman menyebar di halaman rumah penduduk

Berdasarkan persentase, Gambar 30 menunjukkan, penduduk perumahan IPB 1 Baranangsiang lebih menyukai penataan tanaman berbentuk menyebar di halaman ximah mereka. Hal tersebut sesuai dengan penataan tanaman di halaman rumah mereka, seperti yang ditunjukkan pada Gambar 31.

Sebagian halaman rumah dari perumahan IPB 1 Baranangsiang sudah memiliki pola penanaman yang bagus dan menarik. Salah satu contoh halaman rumah dari perumahan tersebut yang efektif dalam mengurangi bising adalah rumah yang berada di jarak $10 \mathrm{~m}$ dari sumber suara.

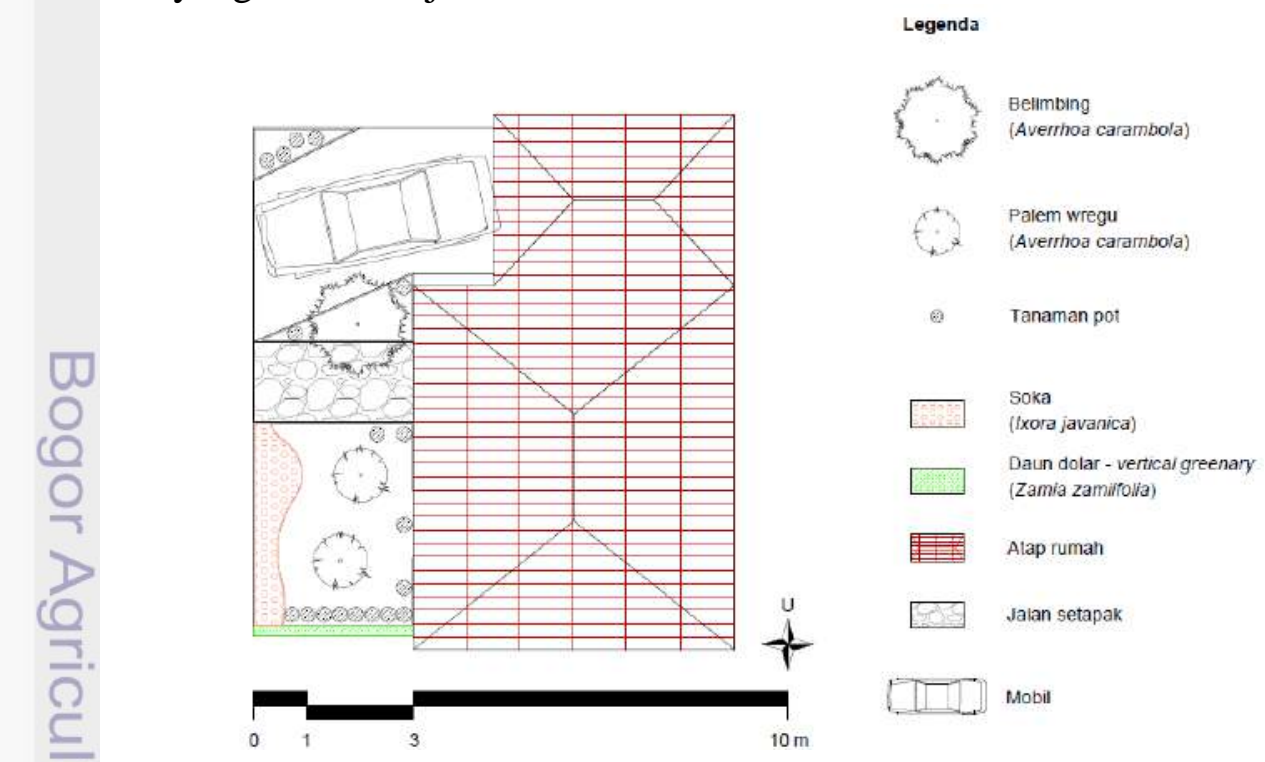

Gambar 32 Halaman rumah yang efektif mengurangi bising

Rumah tersebut berada pada titik 26, dimana memiliki tingkat bising sebesar $\overline{61.02} \mathrm{~dB}$. Berdasarkan hasil wawancara, penghuni rumah tersebut tidak 
merasakan adanya gangguan kebisingan sama sekali, baik gangguan secara fisiologis, psikologis, maupun komunikasi. Halaman rumah tersebut memiliki pola tanaman yang menyebar dan rapat, sehingga suara bising dari kendaraan atau sumber bising yang berada di luar halaman rumah tersebut tidak mempengaruhi penghuni rumah. Sesuai dengan pernyataan Irwan (1994), pola penanaman yang efektif dalam mengurangi bising adalah pola menyebar berstrata banyak dan bergerombol berstrata banyak. Maksud dari berstrata banyak adalah tanaman tersusun dari beberapa baris.

Lingkungan perumahan sebaiknya memberikan kenyamanan bagi para penghuninya. Gambar 33 menunjukkan lingkungan perumahan yang diinginkan oleh responden.
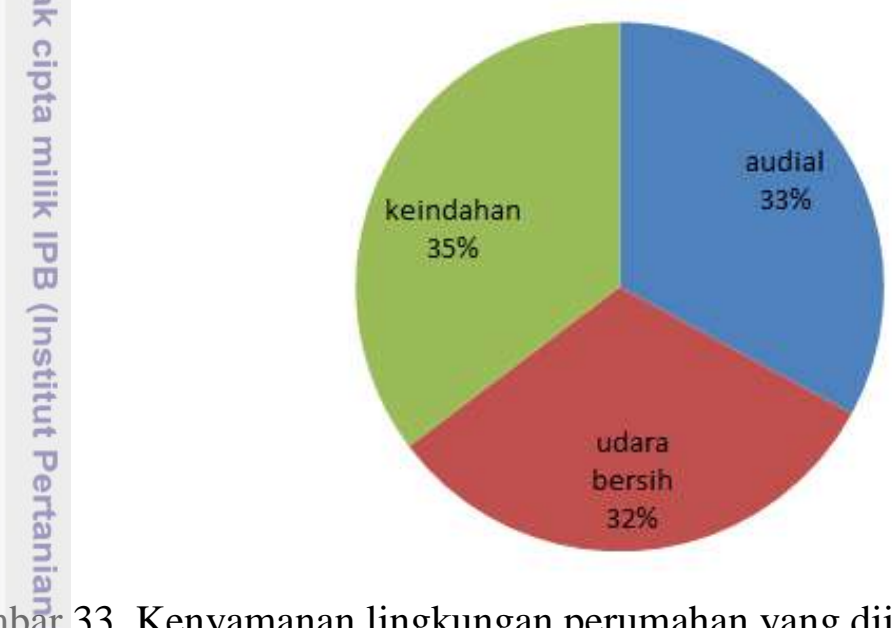

Gambẳr 33 Kenyamanan lingkungan perumahan yang diinginkan responden

Dari p\&̊ำferensi diatas, Gambar 33, menunjukkan bahwa penduduk perumahan IPB I Barañangsiang menyukai lingkungan perumahan yang memberikan kenyamanan secara audial. Dari preferensi diatas, dapat disimpulkan bahwa masalah kebisingan merupakan salah satu masalah lingkungan bagi perumahan tersebut, sehingga dibutuhkan penanganan yang tepat untuk mengurangi kebisingan di perumahan tersebut. Penanganan yang tepat dapat dilakukan beberapa cara, diantaranya menggunakan barrier tanaman ataupun dinding.

\section{Simulasi Penggunaan Penghalang (Barrier)}

\section{Sound pressure level pada simulasi laboratorium}

Berdasarkan pengukuran di lapang, tingkat kebisingan tertinggi terletak pada sumber dari arah timur karena memiliki dua sumber suara, yaitu sumber suara bawah direpresentasikan oleh Jalan Sinangling Padi Ramp dan sumber suara atas yantg direpresentasikan oleh Jalan Pandu Raya. Oleh karena itu, pengambilan rekaman suara traffic noise suara asli di lapang dilakukan di titik tersebut yang nantinya diputar dalam simulasi laboratorium dengan menggunakan speaker. Tingkat kebisingan yang diukur adalah tingkat tekanan suara atau sound pressure level (SPL) yang disesuaikan dengan kondisi lapang yaitu $74 \mathrm{~dB}$ dengan frekuensi $20-20000 \mathrm{~Hz}$. Pengukuran kebisingan latar belakang (background noise) juga dilakukan di ruang semi bebas gema pada frekuensi $20-20000 \mathrm{~Hz}$. Pengukuran dilakukan dalam keadaan sumber bunyi off dan sumber bunyi on dengan cara 
ketiga mikrofon diletakkan pada satu titik yang dianggap mewakili satu ruangan dan sumber bunyi diletakkan di titik rencana pada penelitian utama.
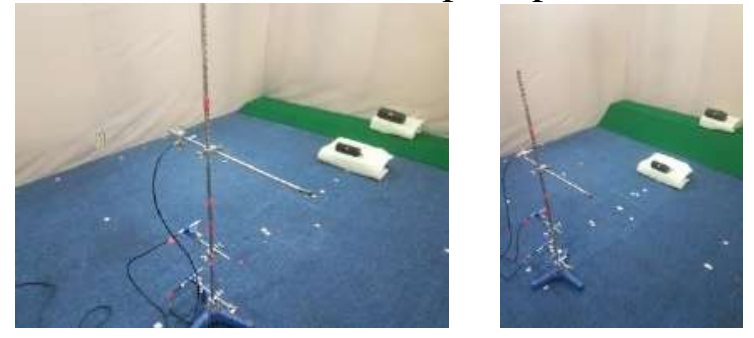

Gambar 34 Pengukuran SPL di ruang semi bebas gema

Tujuan dilakukan pengukuran kebisingan latar belakang adalah memperoleh đata yang dihasilkan sumber bunyi dalam ruangan tanpa pengaruh sumber bunyi đari luar ruangan. Perbedaan hasil pengukuran ini menjadi acuan dalam menentukan besarnya koreksi bising latar belakang. Berikut adalah perbedaan Fàsil pengukuran SPL on dengan SPL saat sumber bunyi off (Tabel 17).

Tabel 17 Perbedaan SPL sumber bunyi on dengan SPL sumber bunyi off pada

\begin{tabular}{|c|c|c|c|c|c|c|}
\hline \multirow{3}{*}{ kuensi (Hz) } & \multicolumn{6}{|c|}{ SPL sumber bunyi on - SPL bunyi off (dB) } \\
\hline & \multicolumn{3}{|c|}{ Frame 1} & \multicolumn{3}{|c|}{ Frame 2} \\
\hline & r 50 & r 100 & r 150 & r 50 & r 100 & r 150 \\
\hline 20 & -2.91 & -2.47 & -1.81 & 9.40 & 8.59 & 8.68 \\
\hline 25 & 1.45 & 4.86 & 1.56 & 19.53 & 18.46 & 19.10 \\
\hline 31.5 & -15.3 & -15.5 & -16.43 & 2.87 & 0.26 & 1.54 \\
\hline 40 & -0.28 & -5.16 & -4.82 & -3.71 & -4.53 & -0.90 \\
\hline 50 & 2.26 & 1.53 & -2.51 & -5.41 & -8.04 & 0.87 \\
\hline 63 & 20.77 & 20.17 & 15.57 & 18.13 & 16.85 & 21.36 \\
\hline 80 & 27.48 & 29.19 & 29.34 & 24.12 & 19.75 & 26.45 \\
\hline 100 & 38.04 & 25.02 & 24.69 & 32.35 & 20.81 & 19.49 \\
\hline 125 & 41.68 & 34.95 & 35.82 & 22.64 & 16.94 & 19.73 \\
\hline 160 & 41.73 & 38.43 & 37.26 & 36.48 & 31.60 & 31.92 \\
\hline 200 & 50.99 & 44.23 & 44.93 & 45.73 & 40.70 & 40.97 \\
\hline 250 & 54.00 & 46.55 & 48.61 & 52.32 & 45.45 & 47.81 \\
\hline 315 & 55.08 & 50.65 & 49.07 & 51.01 & 45.10 & 42.56 \\
\hline 400 & 52.11 & 46.55 & 43.68 & 53.14 & 44.36 & 41.69 \\
\hline 500 & 56.52 & 50.18 & 47.94 & 51.00 & 45.51 & 42.46 \\
\hline 630 & 53.72 & 51.32 & 48.54 & 48.97 & 45.58 & 43.35 \\
\hline 800 & 57.71 & 52.55 & 48.84 & 46.83 & 43.86 & 42.33 \\
\hline 1000 & 57.72 & 51.40 & 48.03 & 49.52 & 46.22 & 39.60 \\
\hline 1250 & 56.94 & 50.45 & 46.82 & 49.12 & 45.87 & 40.28 \\
\hline 1600 & 55.12 & 47.51 & 42.32 & 44.56 & 42.13 & 37.24 \\
\hline 2000 & 52.75 & 46.36 & 41.83 & 38.26 & 38.93 & 31.95 \\
\hline 2500 & 43.41 & 38.79 & 35.19 & 36.38 & 33.33 & 29.68 \\
\hline 3150 & 47.10 & 38.67 & 36.53 & 36.91 & 32.51 & 26.84 \\
\hline 4000 & 45.71 & 36.31 & 31.64 & 35.65 & 29.28 & 22.16 \\
\hline
\end{tabular}

Keterangan: $\mathrm{r}=$ jarak $(\mathrm{cm})$ 
50

Tabel 17 Perbedaan SPL sumber bunyi on dengan SPL sumber bunyi off pada frekuensi $20-20000 \mathrm{~Hz}$ (lanjutan)

\begin{tabular}{|c|c|c|c|c|c|c|}
\hline \multirow{3}{*}{ Frekuensi $(\mathrm{Hz})$} & \multicolumn{6}{|c|}{ SPL sumber bunyi on - SPL bunyi off $(\mathrm{dB})$} \\
\hline & \multicolumn{3}{|c|}{ Frame 1} & \multicolumn{3}{|c|}{ Frame 2} \\
\hline & r 50 & r 100 & r 150 & r 50 & r 100 & r 150 \\
\hline 5000 & 44.22 & 36.78 & 31.00 & 36.31 & 30.54 & 21.56 \\
\hline 6300 & 38.34 & 32.54 & 27.13 & 27.83 & 25.30 & 15.74 \\
\hline 8000 & 35.02 & 33.63 & 25.83 & 23.65 & 24.44 & 15.10 \\
\hline 10000 & 27.85 & 29.92 & 20.82 & 18.66 & 14.98 & 3.52 \\
\hline 12500 & 16.11 & 11.83 & 10.02 & 8.91 & 1.33 & -4.37 \\
\hline 16000 & 4.33 & 1.80 & 0.93 & 0.59 & 0.11 & -4.48 \\
\hline 20000 & 0.61 & 0.67 & 0.82 & 0.06 & 0.04 & -4.70 \\
\hline
\end{tabular}

Keterangan: $\mathrm{r}=\operatorname{jarak}(\mathrm{cm})$

3.

Fienurut Bruel dan Kjaer (1988), koreksi terhadap hasil pengukuran tidak perlu dilakukan apabila SPL sumber bunyi yang bekerja (on) dengan SPL bunyi latar belakang (off) lebih besar dari $10 \mathrm{~dB}$, namun jika perbedaannya kurang dari 3 $\mathrm{dB}$ mak a pengukuran tidak dapat dilakukan. Berdasarkan Tabel 18, koreksi tidak perlu đilakukan pada frekuensi $63-8000 \mathrm{~Hz}$, karena perbedaan SPL sumber bunyi ôn dengan SPL bunyi latar belakang $>10 \mathrm{~dB}$, selain itu untuk memudahkan dalam pengolahan data range frekuensi tersebut dipilih dalam penelitian utama. Adapun menurut Wilson (1994) terdapat sepuluh frekuensi standar, yaitu frekueñsi rendah dan frekuensi tinggi. Frekuensi rendah meliputi $31.5 \mathrm{~Hz}, 63 \mathrm{~Hz}$, $125 \mathrm{~Hz}$, $250 \mathrm{~Hz}$, dan $500 \mathrm{~Hz}$, sedangkan frekuensi tinggi meliputi $1000 \mathrm{~Hz}, 2000$ $\mathrm{Hz}, 4080 \mathrm{~Hz}, 8000 \mathrm{~Hz}$, dan $16000 \mathrm{~Hz}$.

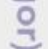

\section{Penyusunan tanaman berkelompok}

a. Pohon

Jenis pohon yang digunakan dalam penelitian ini adalah pohon damar (Agathis dammara Lamb.). Tanaman ini memiliki karakteristik daun sedang dan tebal. Gambar 35 dari Lampiran 4 menunjukkan bahwa pohon efektif mengurangi kebisingan pada frekuensi $5000 \mathrm{~Hz}, 6300 \mathrm{~Hz}$, dan $8000 \mathrm{~Hz}$, karena nilai IL yang dihasilkan $\geq 3 \mathrm{~dB}$ sebagaimana kemampuan sensitivitas telinga normal manusia (Bruel dan Kjaer 1988).

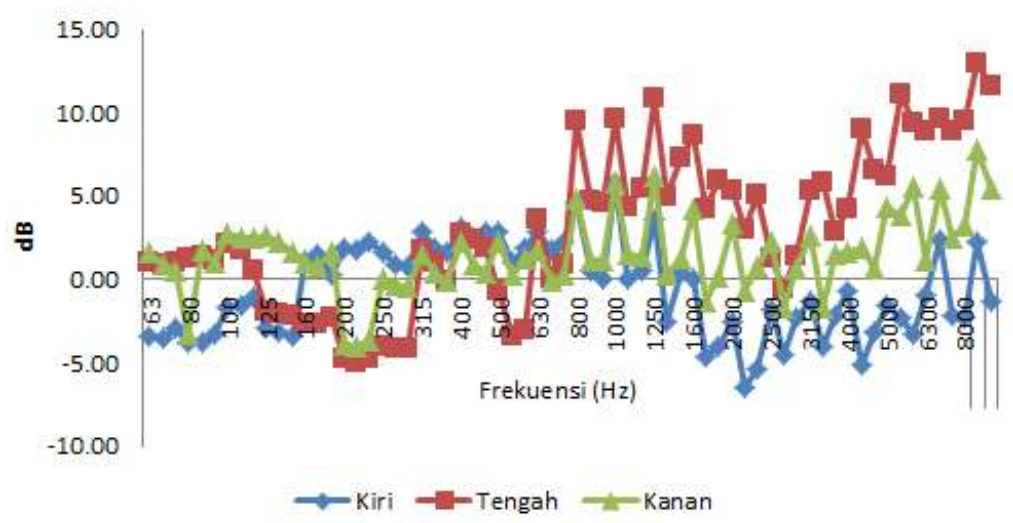

(a) 


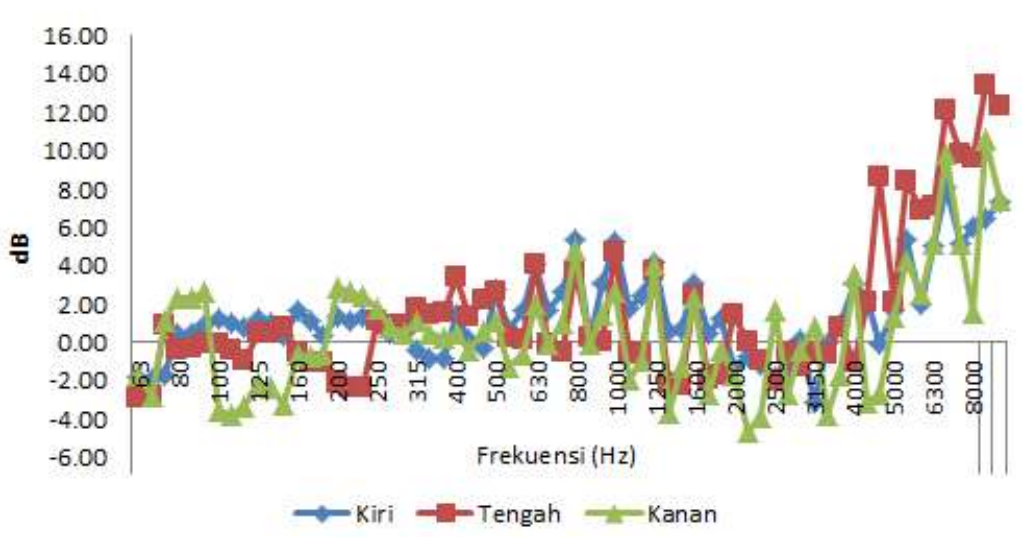

(b)

Gambar 35 IL pohon susunan berkelompok pada (a) frame 1 (b) frame 2

Lampiran 4 menunjukkan pada frame 1 susunan pohon berkelompok dapat 㶾ereduksi bising pada frekuensi $5000 \mathrm{~Hz}$ dan $8000 \mathrm{~Hz}$, sedangkan pada frame 2, susunan pohon dapat mereduksi pohon pada frekuensi $6300 \mathrm{~Hz}$ dan $8000 \mathrm{~Hz}$. Berdasarkan penjelasan tersebut menunjukkan bahwa pada kedua frame, propagasi suara sangat efektif untuk direduksi oleh tanaman dengan pola penyusunan berkelompok pada frekuensi $5000 \mathrm{~Hz}, 6300 \mathrm{~Hz}$, dan $8000 \mathrm{~Hz}$, sehingga walaupun sumber suara berasal dari ketinggian yang berbeda, pohon dengan susunan berkelompok efektif untuk mereduksi bising pada frekuensi inggi. Seperti dalam pernyataan Carpenter et al (1975), bahwa penghalang Jegetasi dengan kerapatan tanam yang tinggi lebih efektif mereduksi kebisingan dibandingkan dengan penghalang vegetasi yang ditanam dengan kerapatan țtmbuh rendah.
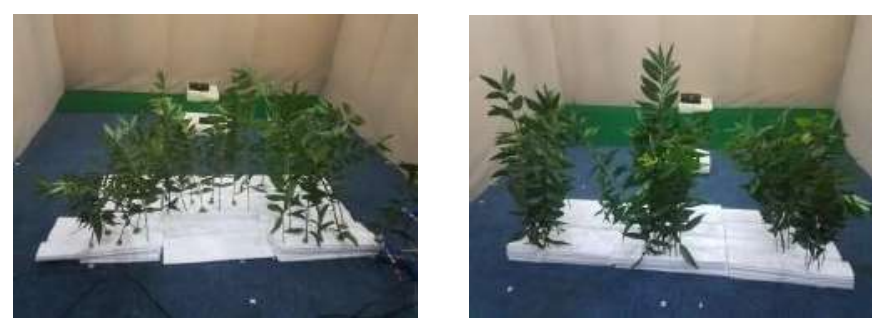

Gambar 36 Penyusunan pohon berkelompok

Pada frekuensi $5000 \mathrm{~Hz}$ memiliki nilai IL sebesar $11.11 \mathrm{~dB}$, frekuensi 6300 Hz memiliki nilai IL sebesar $12.10 \mathrm{~dB}$, serta frekuensi $8000 \mathrm{~Hz}$ memiliki nilai IL sebesar $13.42 \mathrm{~dB}$. Hal ini berarti susunan pohon berkelompok sangat efektif mereduksi bising hingga $12.21 \%$. Oleh karena itu dapat disimpulkan bahwa walaupun kedua sumber suara berada pada level ketinggian yang tidak berbeda jauh maupun berada pada level ketinggian yang berbeda jauh, susunan pohon berkelompok sangat efektif mereduksi pada frekuensi tinggi. Peningkatan IL pada frekuensi tersebut menunjukkan bahwa susunan pohon berkelompok mampu memantulkan suara, dimana suara akan dipantulkan oleh bagian batang, daun, dan cabang dari pohon-pohon tersebut. 


\section{b. Semak}

Tanaman semak yang digunakan dalam penelitian ini adalah pucuk merah (Syzygium oleana Br.Ex) pada frame 1 dan teh-tehan (Acalypha siamensis Oliv. ex Gage) pada frame 2. Tanaman pucuk merah memiliki karakteristik daun sedang - tipis - halus, sedangkan tanaman teh-tehan memiliki karakteristik daun sedang - tipis - kasar. Gambar 37 dari Lampiran 5 menunjukkan bahwa semak efektif mengurangi kebisingan pada frekuensi $63 \mathrm{~Hz}, 200 \mathrm{~Hz}, 250 \mathrm{~Hz}, 315 \mathrm{~Hz}$, $1000 \mathrm{~Hz}, 1250 \mathrm{~Hz}, 1600 \mathrm{~Hz}, 2000 \mathrm{~Hz}, 2500 \mathrm{~Hz}$, dan $8000 \mathrm{~Hz}$, karena nilai IL yang dihasilkan $\geq 3 \mathrm{~dB}$ sebagaimana kemampuan sensitivitas telinga normal manusia (Bruel dan Kjaer 1988).

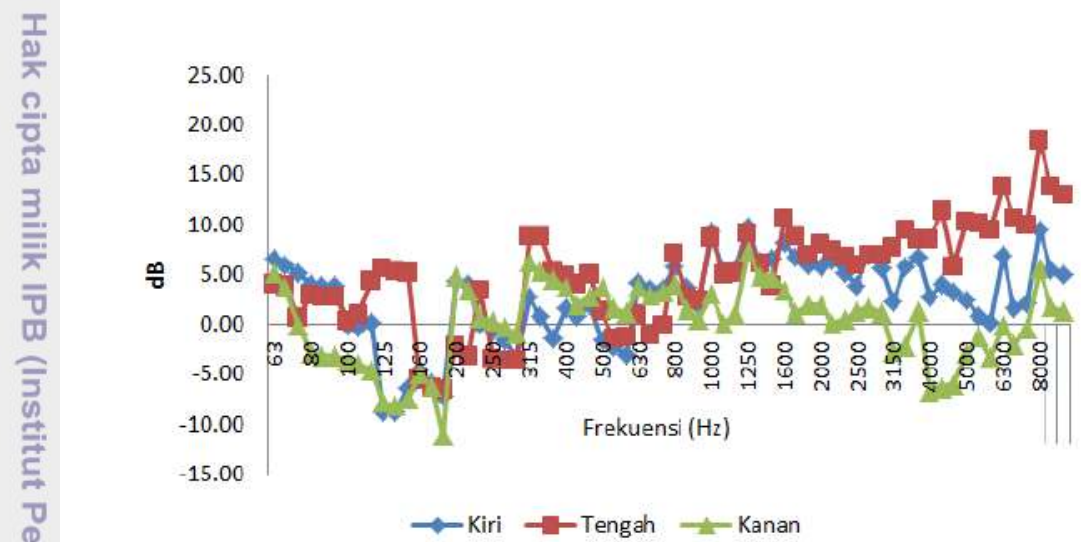

(a)

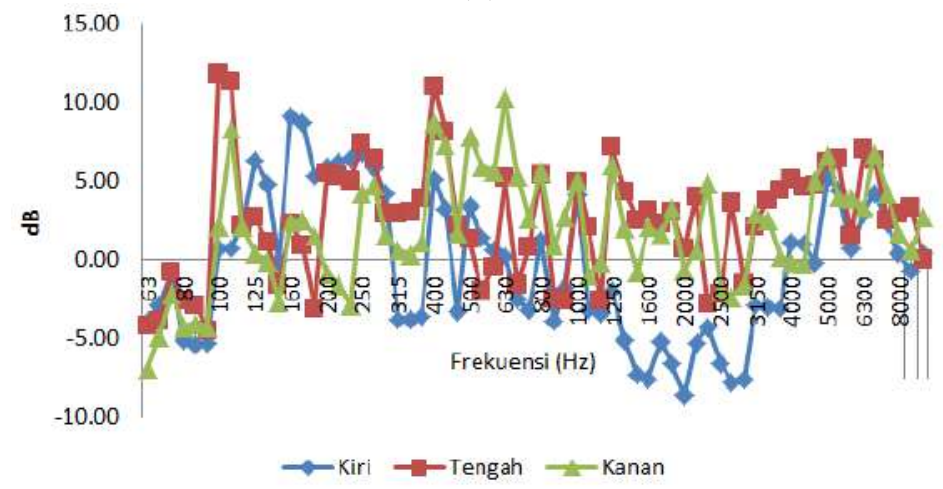

(b)

Gambar 37 IL semak susunan berkelompok pada (a) frame 1 (b) frame 2

Lampiran 5 menunjukkan pada frame 1, susunan semak berkelompok mereduksi bising pada frekuensi $63 \mathrm{~Hz}, 315 \mathrm{~Hz}, 1000 \mathrm{~Hz}, 1250 \mathrm{~Hz}, 1600 \mathrm{~Hz}, 2000 \mathrm{~Hz}, 2500$ $\mathrm{Hz}$, dan $8000 \mathrm{~Hz}$. Kemudian pada frame 2 susunan semak mereduksi bising pada frekuensi $200 \mathrm{~Hz}$, dan $250 \mathrm{~Hz}$. Pada Gambar 38 dapat terlihat bahwa jumlah tanaman yang digunakan pada frame 1 lebih banyak dibandingkan dengan jumlah tanaman yang digunakan pada frame 2 , sehingga pada kedua frame tersebut terdapat perbedaan frekuensi dalam mereduksi bising. Berdasarkan penjelasan tersebut terlihat bahwa susunan semak berkelompok dapat mereduksi bising pada frekuensi rendah dan tinggi. 

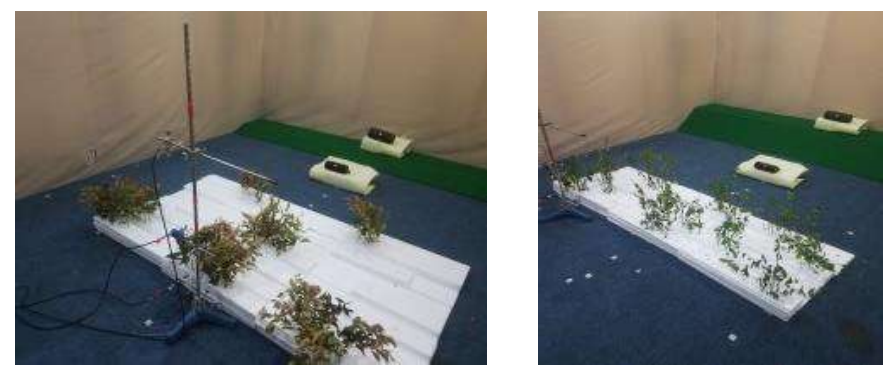

Gambar 38 Penyusunan semak berkelompok

Pada frekuensi $63 \mathrm{~Hz}$ memiliki nilai IL sebesar $6.60 \mathrm{~dB}$, frekuensi $200 \mathrm{~Hz}$ 商emiliki nilai IL sebesar $6.42 \mathrm{~dB}$, frekuensi $250 \mathrm{~Hz}$ memiliki nilai IL sebesar ₹. $43 \mathrm{~dB}$, frekuensi $315 \mathrm{~Hz}$ memiliki nilai IL sebesar $8.90 \mathrm{~dB}$, frekuensi $1000 \mathrm{~Hz}$ miliki nilai IL sebesar $9.38 \mathrm{~dB}$, frekuensi $1250 \mathrm{~Hz}$ memiliki nilai IL sebesar 9. $89 \mathrm{~dB}$, frekuensi $1600 \mathrm{~Hz}$ memiliki nilai IL sebesar 10.67, frekuensi $2000 \mathrm{~Hz}$ memiliki nilai IL sebesar $8.01 \mathrm{~dB}$, frekuensi $2500 \mathrm{~Hz}$ memiliki nilai IL sebesar

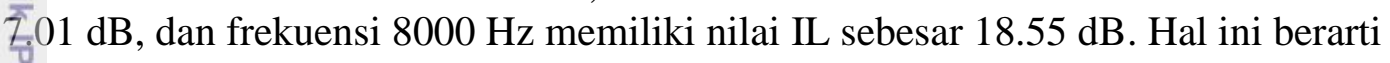
susunan semak berkelompok efektif mereduksi bising hingga 9.28\%. Penjelasan Giatas dapat disimpulkan bahwa apabila kedua sumber suara berada pada level Ketinggian yang tidak berbeda jauh maka susunan semak berkelompok efektif

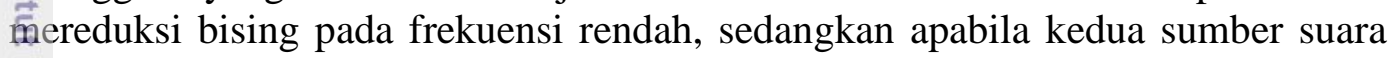
berada pada level ketinggian yang berbeda maka susunan semak berkelompok sangat efektif mereduksi bising pada frekuensi tinggi.

Kombinasi pohon dan semak

Kombinasi pohon dan semak yang digunakan adalah kombinasi antara pohon damar (Agathis dammara Lamb.) dan semak pucuk merah (Syzygium Oleana Br.Ex) pada frame 1 dan kombinasi antara pohon damar (Agathis dammara Lamb.) dan semak teh-tehan (Acalypha siamensis Oliv. ex Gage) pada frame 2. Tanaman pohon damar memiliki karakteristik daun sedang - tebal halus, tanaman pucuk merah memiliki karakteristik daun sedang - tipis - halus, dan tanaman teh-tehan memiliki karakteristik daun sedang - tipis - kasar. Gambar 39 dari Lampiran 6 menunjukkan bahwa semak efektif mengurangi kebisingan pada frekuensi $160 \mathrm{~Hz}$ pada frame 1, serta pada frame 2 terjadi pada frekuensi $8000 \mathrm{~Hz}$.

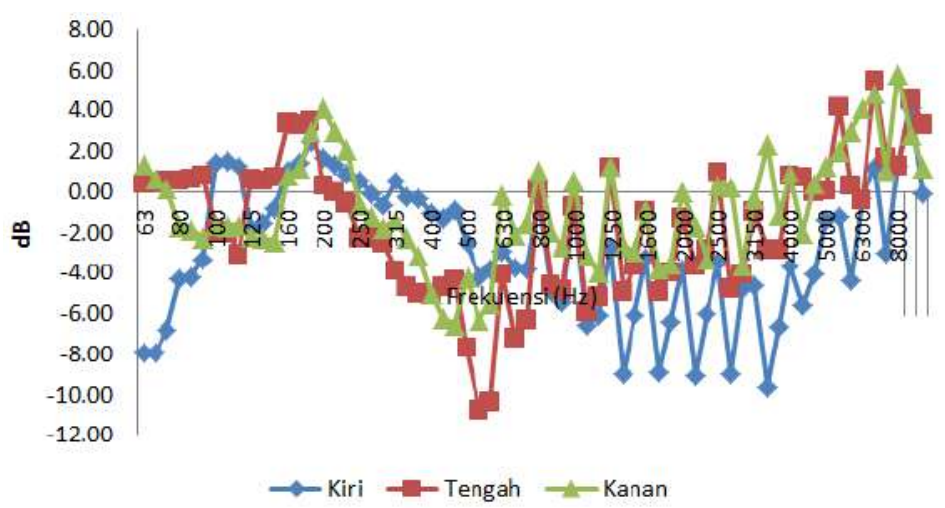

(a) 


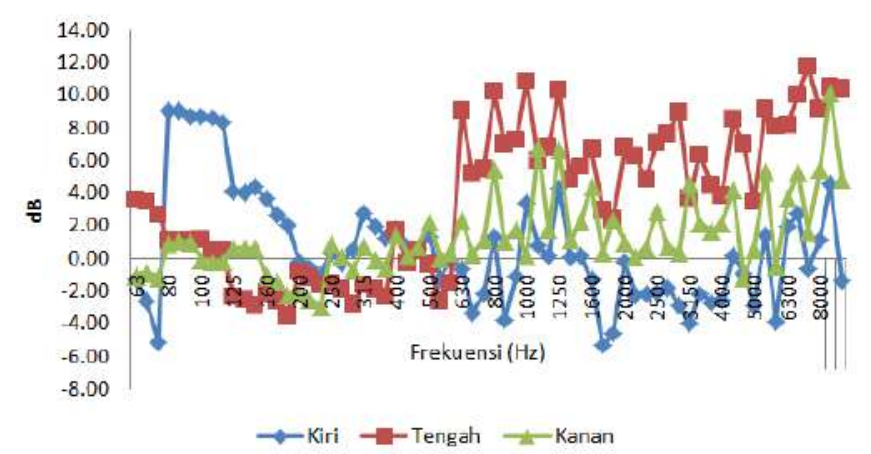

(b)

Gaṃbar 39 IL kombinasi susunan berkelompok pada (a) frame 1 (b) frame 2

Lampiᄑ्ĩan 6 menunjukkan bahwa pada frame 1 susunan kombinasi tanaman semak dan pöhon mereduksi bising pada frekuensi $160 \mathrm{~Hz}$, sedangkan pada frame 2 susuna kombinasi tanaman mereduksi bising pada frekuensi $8000 \mathrm{~Hz}$. Pada Gambar 40 dapat dilihat bahwa pada frame 1 jumlah susunan pohon lebih sedikit dibanđingkan dengan jumlah semak, sehingga kombinasi penyusunan semak dan pohon efektif mereduksi pada frekuensi rendah. Sementara itu, pada frame 2 jumlali susunan pohon lebih banyak dibandingkan dengan jumlah semak yang digunakan, sehingga kombinasi penyusunan semak dan pohon efektif mereduksi bising ada frekuensi tinggi.
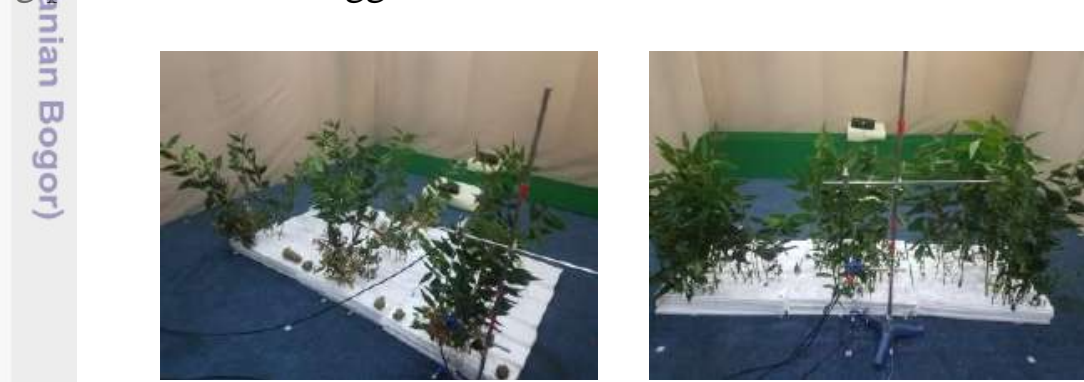

Gambar 40 Penyusunan kombinasi tanaman berkelompok

Pada frekuensi $160 \mathrm{~Hz}$ memiliki nilai IL sebesar $3.50 \mathrm{~dB}$ dan frekuensi 8000 $\mathrm{Hz}$ memiliki nilai IL sebesar $10.50 \mathrm{~dB}$, sehingga diketahui bahwa penyusunan kombinasi semak dan pohon dengan pola berkelompok efektif mereduksi bising hingga 7\%. Oleh karena itu, kesimpulan berdasarkan pernyataan diatas adalah apabila level kedua sumber suara berasal dari ketinggian yang tidak berbeda jauh dan jumlah tanaman semak lebih banyak dibandingkan jumlah pohon maka kombinasi penyusunan pohon dan semak berkelompok efektif mereduksi bising pada frekuensi rendah. Sementara itu, apabila kedua sumber suara berasal dari level ketinggian yang berbeda jauh dan jumlah pohon lebih banyak dibandingkan dengan semak maka kombinasi penyusunan antara pohon dan semak berkelompok sangat efektif mereduksi bising pada frekuensi tinggi.

\section{Penyusunan tanaman menyebar}

a. Pohon

Jenis pohon yang digunakan dalam penelitian ini adalah pohon damar (Agathis dammara Lamb.). Tanaman ini memiliki karakteristik daun sedang dan 
tebal. Gambar 41 dari Lampiran 7 menunjukkan bahwa pohon dengan pola penyusunan menyebar mampu mengurangi kebisingan pada frekuensi $80 \mathrm{~Hz}$, $3150 \mathrm{~Hz}, 4000 \mathrm{~Hz}, 5000 \mathrm{~Hz}, 6300 \mathrm{~Hz}$, dan $8000 \mathrm{~Hz}$ karena nilai IL yang dihasilkan $\geq 3 \mathrm{~dB}$.

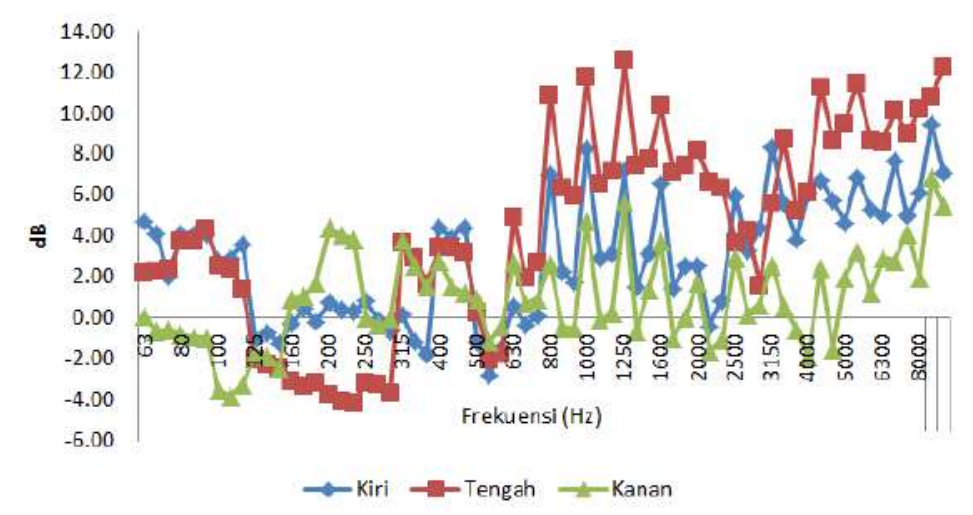

(a)

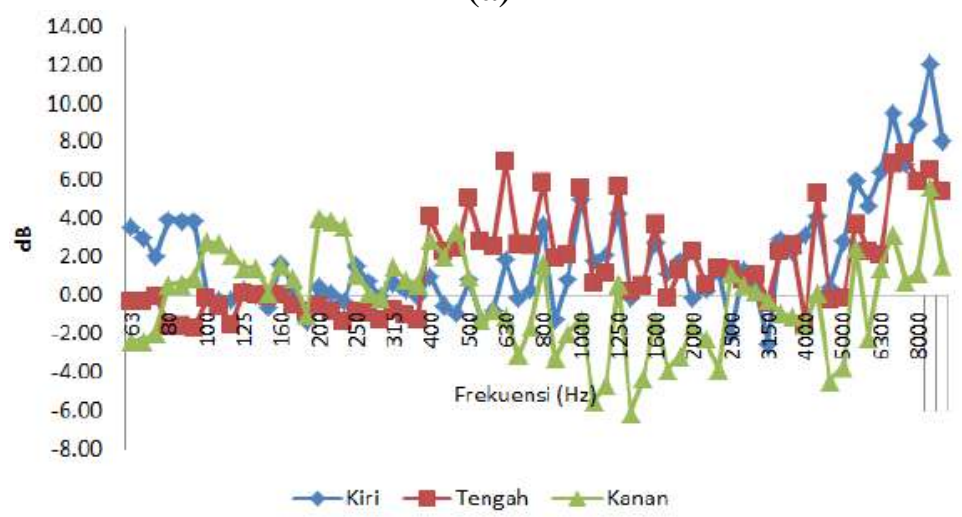

(b)

Gambar 41 IL pohon susunan menyebar pada (a) frame 1 (b) frame 2

Berdasarkan Lampiran 7, pada frame 1 susunan pohon menyebar mampu mereduksi bising pada frekuensi $80 \mathrm{~Hz}, 3150 \mathrm{~Hz}, 4000 \mathrm{~Hz}, 5000 \mathrm{~Hz}, 6300 \mathrm{~Hz}$, dan $8000 \mathrm{~Hz}$, sedangkan pada frame 2 susunan pohon menyebar mampu mereduksi bising pada frekuensi $8000 \mathrm{~Hz}$. Dari penjelasan kedua frame tersebut, dapat diketahui bahwa pohon dengan susunan menyebar mampu untuk mereduksi bising pada frekuensi rendah dan tinggi.

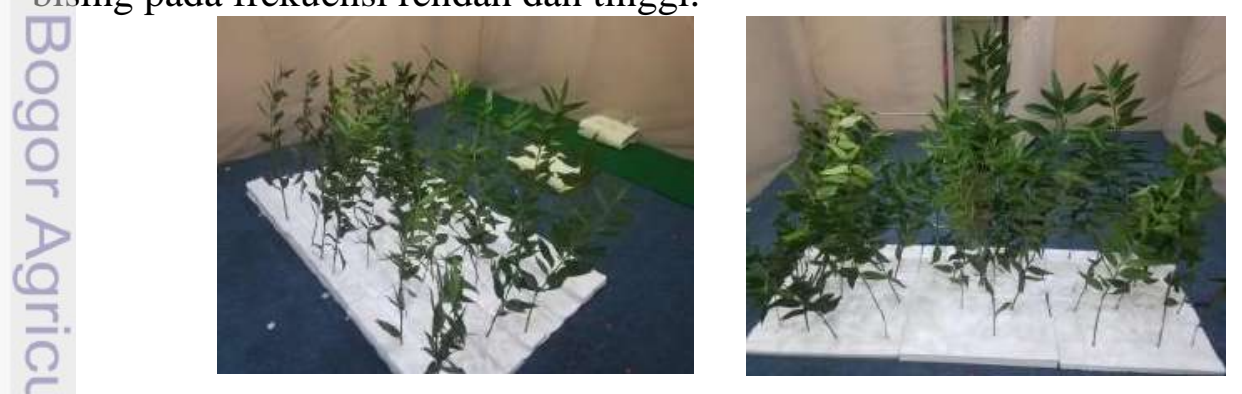

Gambar 42 Penyusunan pohon menyebar

Pada frekuensi $80 \mathrm{~Hz}$ memiliki nilai IL sebesar $4.15 \mathrm{~dB}$, frekuensi $3150 \mathrm{~Hz}$ memiliki nilai IL sebesar 8.73, frekuensi $4000 \mathrm{~Hz}$ memiliki nilai IL sebesar 11.28 $\mathrm{dB}$, frekuensi $5000 \mathrm{~Hz}$ memiliki nilai IL sebesar $11.49 \mathrm{~dB}$, frekuensi $6300 \mathrm{~Hz}$ 
memiliki nilai IL sebesar $10.14 \mathrm{~dB}$, dan frekuensi $8000 \mathrm{~Hz}$ memiliki nilai IL sebesar $12.31 \mathrm{~dB}$. Diketahui bahwa penyusunan pohon menyebar efektif mereduksi bising hingga 9.66\%, sehingga dapat disimpulkan bahwa apabila kedua sumber suara berada pada level ketinggian yang tidak berbeda jauh maka susunan pohon menyebar sangat efektif mereduksi bising pada frekuensi rendah dan tinggi, namun apabila kedua sumber suara berada pada level ketinggian yang berbeda jauh maka susunan pohon menyebar efektif mereduksi bising pada frekuensi tinggi.

\section{b. Semak}

Jênis semak yang digunakan dalam menyusun pola menyebar adalah pucuk merah (Syzygium oleana Br.Ex) pada frame 1 dan teh-tehan (Acalypha siamensis Oliv. ex Gage) pada frame 2. Karakteristik daun dari tanaman pucuk merah adalah sedang - tipis - halus, sedangkan tanaman teh-tehan memiliki karakteristik daun sedang- tipis - kasar. Berdasarkan Gambar 43 dari Lampiran 8 menunjukkan bahwa semak dengan susunan pola menyebar mampu untuk mengurangi bising pada frekuensi $200 \mathrm{~Hz}, 250 \mathrm{~Hz}, 315 \mathrm{~Hz}, 400 \mathrm{~Hz}, 1250 \mathrm{~Hz}$, dan $8000 \mathrm{~Hz}$, dengan nilai It yang dihasilkan $\geq 3 \mathrm{~dB}$.
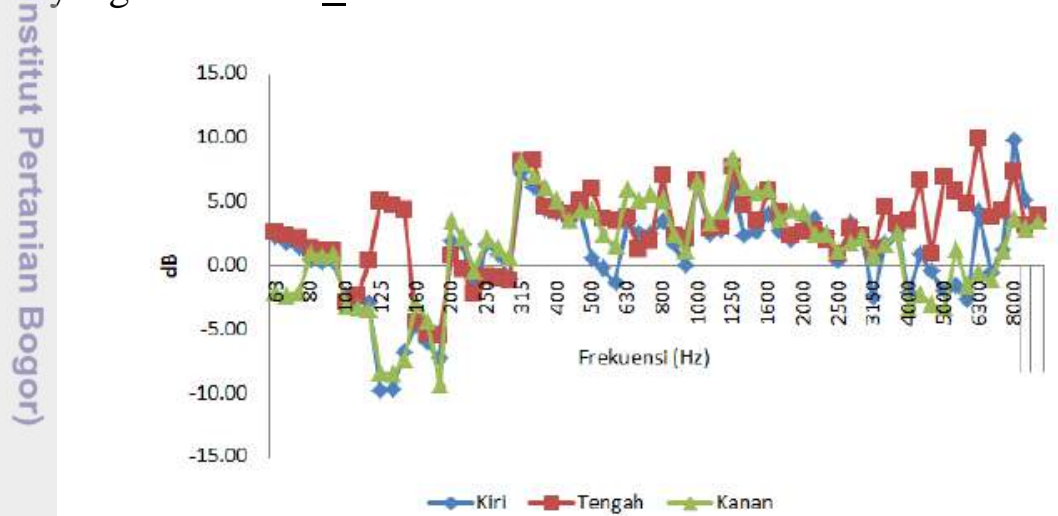

(a)

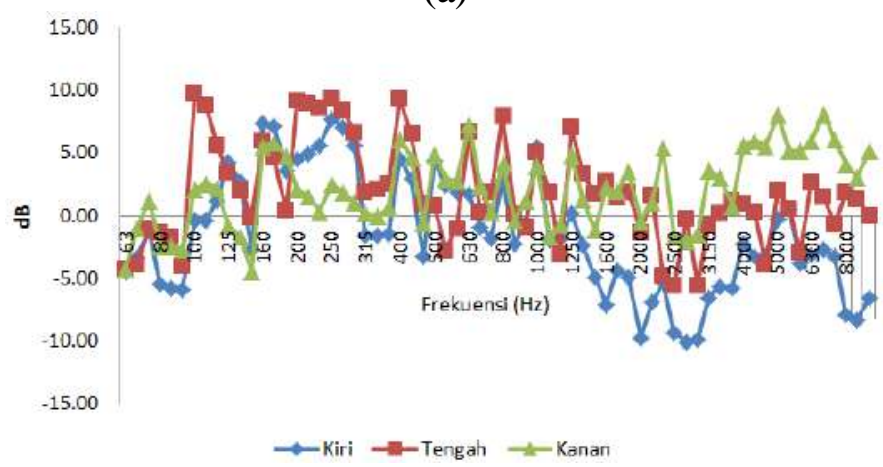

(b)

Gambar 43 IL semak susunan menyebar pada (a) frame 1 (b) frame 2

Pada frame 1 yang terdapat pada Lampiran 8, menunjukkan susunan semak mampu mereduksi bising pada frekuensi $315 \mathrm{~Hz}, 400 \mathrm{~Hz}, 1250 \mathrm{~Hz}$, dan $8000 \mathrm{~Hz}$, sedangkan pada frame 2 susunan semak mereduksi bising pada frekuensi $200 \mathrm{~Hz}$ dan 250 Hz. Gambar 44 menunjukkan pada frame 1 terlihat bahwa jumlah semak terlihat lebih banyak dan susunan semak rapat sehingga propagasi suara dapat direduksi pada frekuensi rendah dan tinggi, sedangkan pada frame 2 terlihat 
bahwa jumlah semak lebih sedikit dan susunan semak kurang rapat sehingga propagasi suara hanya dapat direduksi pada frekuensi rendah.
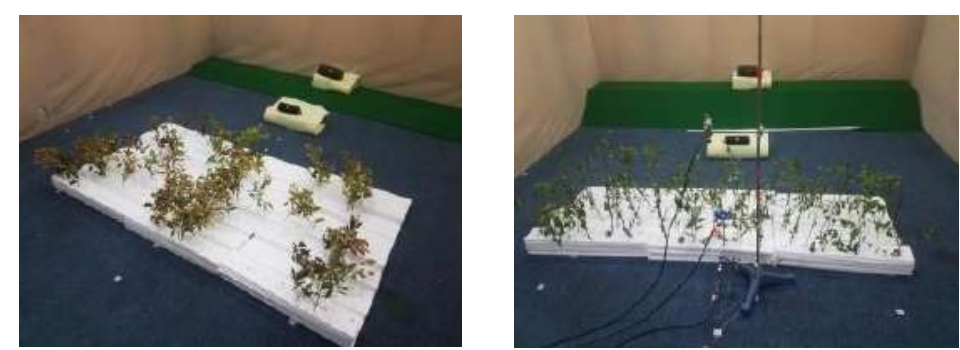

Gambar 44 Penyusunan semak menyebar

Pada frekuensi $200 \mathrm{~Hz}$ memiliki nilai IL sebesar $9.16 \mathrm{~dB}$, frekuensi $250 \mathrm{~Hz}$ memiliki nilai IL sebesar $9.45 \mathrm{~dB}$, frekuensi $315 \mathrm{~Hz}$ memiliki nilai IL sebesar $8.25 \mathrm{~dB}$, frekuensi $400 \mathrm{~Hz}$ memiliki nilai IL sebesar $5.10 \mathrm{~dB}$, frekuensi $1250 \mathrm{~Hz}$ memiliki nilai IL sebesar $8.40 \mathrm{~dB}$, dan frekuensi $8000 \mathrm{~Hz}$ memiliki nilai IL se besar $9.74 \mathrm{~dB}$. Oleh karena itu, penyusunan semak menyebar efektif mereduksi bising hingga $8.35 \%$, sehingga dapat disimpulkan apabila kedua sumber suara berada pada level ketinggian yang sama (tidak berbeda jauh) dengan jumlah semak yang banyak maka susunan semak menyebar efektif mengurangi bising pada frekuensi rendah dan tinggi, sedangkan apabila kedua sumber suara berada pada level ketinggian yang berbeda jauh dengan jumlah semak sedikit maka sisunan semak menyebar efektif mereduksi pada frekuensi rendah.

Kombinasi pohon dan semak

Kombinasi pohon dan semak yang digunakan dalam model penyusunan menyebar ini adalah kombinasi antara pohon damar (Agathis dammara Lamb.) dan semak pucuk merah (Syzygium oleana Br.Ex) pada frame 1 serta kombinasi pohon damar (Agathis dammara Lamb.) dan semak teh-tehan (Acalypha siamensis Oliv. ex Gage) pada frame 2. Tanaman pohon damar memiliki karakteristik daun sedang - tebal - halus, tanaman pucuk merah memiliki karakteristik daun sedang - tipis - halus, dan tanaman teh-tehan memiliki karakteristik daun sedang - tipis - kasar. Pada Gambar 45 dari Lampiran 9 bahwa kombinasi kedua tanaman tersebut mampu mereduksi bising pada frekuensi 200 $\mathrm{Hz}, 630 \mathrm{~Hz}, 800 \mathrm{~Hz}, 6300 \mathrm{~Hz}$, dan $8000 \mathrm{~Hz}$, dengan nilai IL yang dihasilkan $\geq 3$ dB.

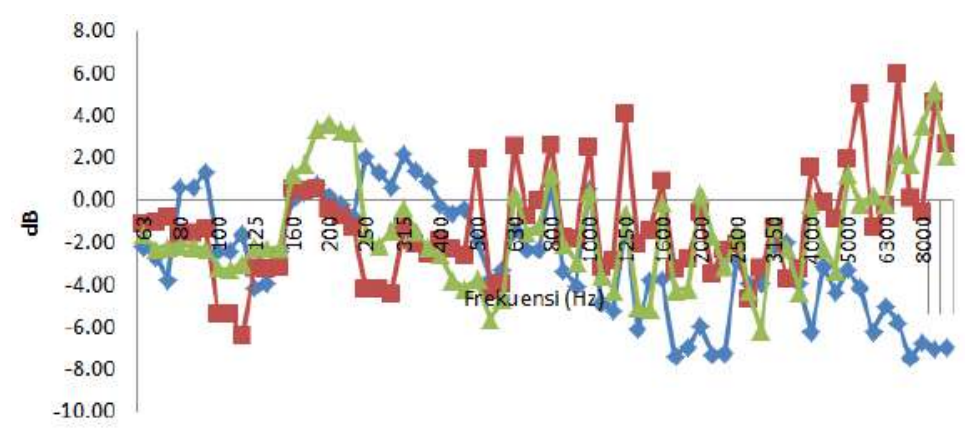


(a)

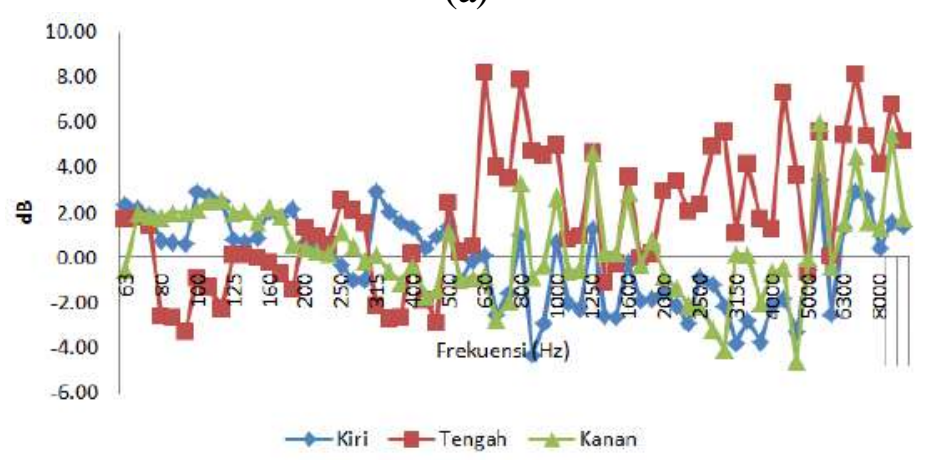

(b)

Gambar 45 IL kombinasi susunan menyebar pada (a) frame 1 (b) frame 2

Pada frame 1 dari Lampiran 9, kombinasi kedua tanaman mereduksi bising pada frekuensi $200 \mathrm{~Hz}$ dan $8000 \mathrm{~Hz}$, sedangkan pada frame 2, kombinasi kedua tanamần mereduksi bising pada frekuensi $630 \mathrm{~Hz}, 800 \mathrm{~Hz}, 6300 \mathrm{~Hz}$, dan $8000 \mathrm{~Hz}$. Dari Gambar 46 terlihat bahwa pada frame 1 jumlah pohon lebih sedikit dibanđingkan dengan frame 2, namun untuk jumlah semak terlihat lebih banyak dibandingkan frame 2. Oleh karena itu, pada frame 1 jumlah frekuensi yang dapat diredu表si oleh kombinasi pohon dan semak menyebar lebih sedikit dibandingkan dengañjumlah frekuensi pada frame 2 .
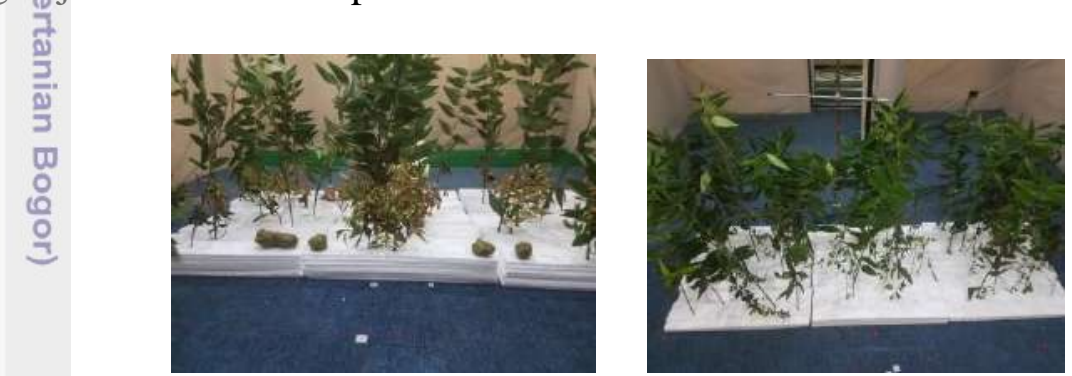

Gambar 46 Penyusunan kombinasi tanaman menyebar

Pada frekuensi $200 \mathrm{~Hz}$ memiliki nilai IL sebesar $3.62 \mathrm{~dB}$, frekuensi $630 \mathrm{~Hz}$ memiliki nilai IL sebesar $8.22 \mathrm{~dB}$, frekuensi $800 \mathrm{~Hz}$ memiliki nilai IL sebesar 7.91, frekuensi $6300 \mathrm{~Hz}$ memiliki nilai IL sebesar $8.14 \mathrm{~dB}$, dan frekuensi $8000 \mathrm{~Hz}$ memiliki nilai IL sebesar $6.79 \mathrm{~dB}$. Kombinasi susunan pohon dan semak dengan pola menyebar efektif mereduksi bising hingga 6.93\%. Dapat disimpulkan apabila kedua sumber suara yang berasal dari level ketinggian yang sama maupun berbeda makaCkombinasi tanaman pohon dan semak efektif mereduksi bising pada frekuensi rendah dan tinggi.

\section{Penyusunan tanaman berbentuk jalur}

a. Pøhon

Jenis pohon yang digunakan dalam penelitian ini adalah pohon damar (Agathis dammara Lamb.). Tanaman ini memiliki karakteristik daun sedang tebal =halus. Gambar 47 dari Lampiran 10 menunjukkan bahwa pohon efektif mengürangi kebisingan pada frekuensi $125 \mathrm{~Hz}, 200 \mathrm{~Hz}, 315 \mathrm{~Hz}, 400 \mathrm{~Hz}$, dan $8000 \mathrm{~Hz}$, dengan nilai IL yang dihasilkan $\geq 3 \mathrm{~dB}$. 


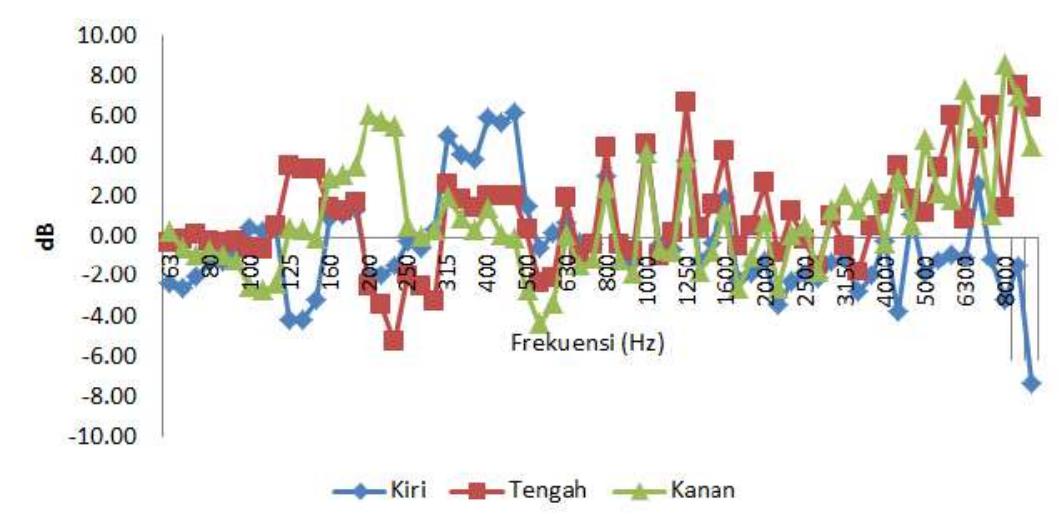

(a)

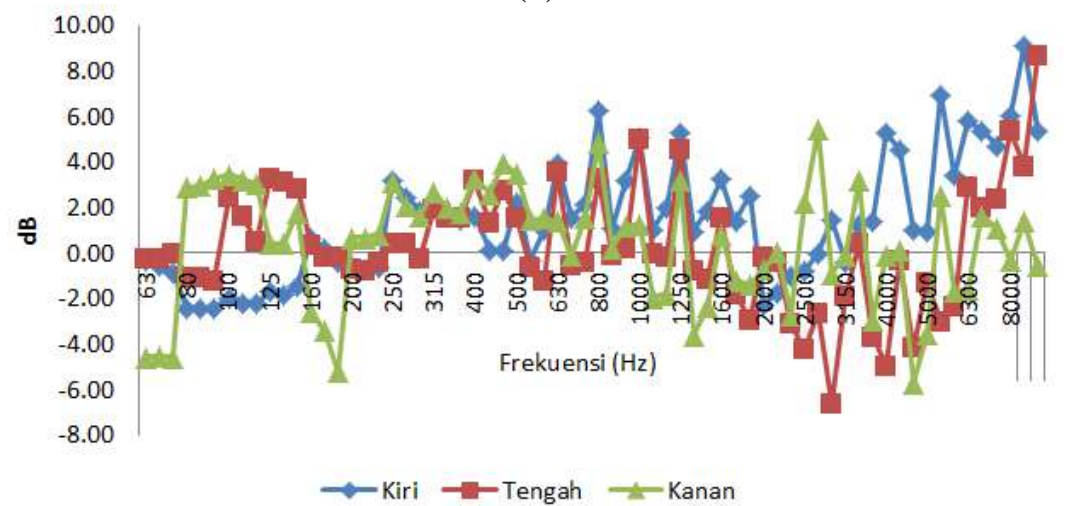

(b)

Gambar 47 IL pohon susunan bentuk jalur pada (a) frame 1 (b) frame 2 Eampiran 10 menunjukkan pada frame 1, susunan pohon mereduksi bising pada frekuensi $125 \mathrm{~Hz}, 200 \mathrm{~Hz}, 315 \mathrm{~Hz}, 400 \mathrm{~Hz}$, dan $8000 \mathrm{~Hz}$. Sementara itu pada frame 2, susunan pohon di titik kiri mereduksi bising pada frekuensi $8000 \mathrm{~Hz}$. Dapat diketahui bahwa susunan pohon berbentuk jalur mampu mereduksi bising pada frekuensi rendah dan tinggi. Gambar 48 menunjukkan bahwa pada frame 2 susunan pohon berbentuk jalur hanya mereduksi pada satu frekuensi dapat disebabkan oleh ketinggian tanaman yang digunakan tidak seragam sehingga menyebabkan daun-daun antar pohon saling bersinggungan, namun untuk bagian batang pohon tidak rapat. Oleh karena itu, propagasi kedua sumber suara dapat dipantulkan oleh dedaunan tetapi tidak dapat dipantulkan oleh batang pohon karena suara akan loss.
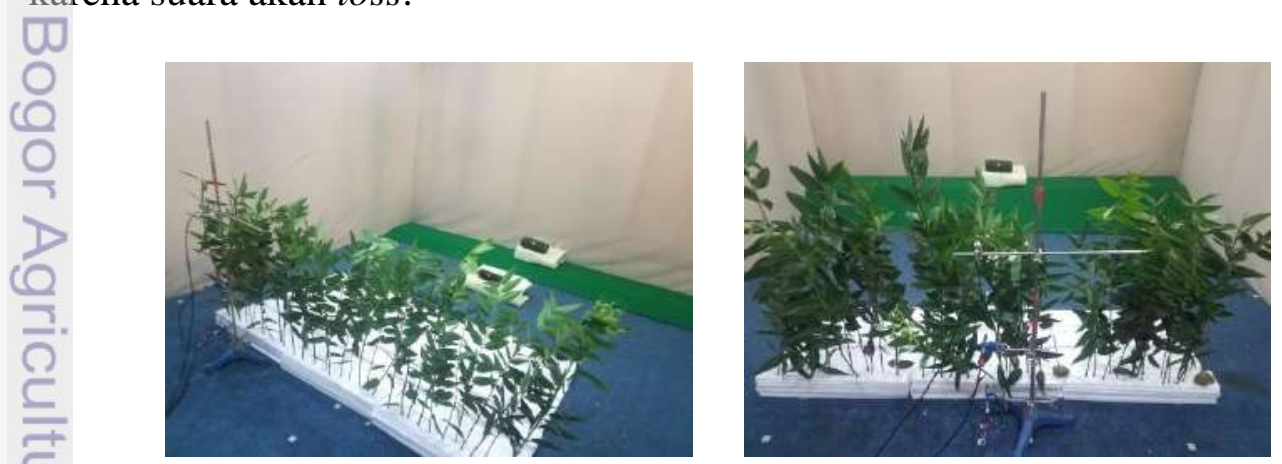

Gambar 48 Penyusunan pohon berbentuk jalur 
Pada frekuensi $125 \mathrm{~Hz}$ memiliki nilai IL sebesar $3.44 \mathrm{~dB}$, frekuensi $200 \mathrm{~Hz}$ memiliki nilai IL $6.06 \mathrm{~Hz}$, frekuensi $315 \mathrm{~Hz}$ memiliki nilai IL $5.00 \mathrm{~dB}$, frekuensi $400 \mathrm{~Hz}$ memiliki nilai IL $6.09 \mathrm{~dB}$, dan frekuensi $8000 \mathrm{~Hz}$ memiliki nilai IL 9.10 dB. Dari penjelasan tersebut diketahui bahwa susunan pohon berbentuk jalur efektif mereduksi bising hingga 5.9\%, sehingga disimpulkan bahwa apabila kedua sumber suara berada pada level ketinggian yang tidak berbeda jauh (sama) maka susunan pohon berbentuk jalur efektif mereduksi bising pada frekuensi rendah dan tinggi, namun apabila kedua sumber suara berada pada level ketinggian yang berbeda maka susunan pohon berbentuk jalur sangat efektif mereduksi bising pada frekuensi tinggi.

b. Semak

fenis semak yang digunakan dalam menyusun pola bentuk jalur adalah pucuk merah (Syzygium oleana Br.Ex) pada frame 1 dan teh-tehan (Acalypha siamensis Oliv. ex Gage) pada frame 2. Karakteristik daun dari tanaman pucuk merah ẩdalah kecil - tipis - halus, sedangkan karakteristik daun dari tanaman teh-

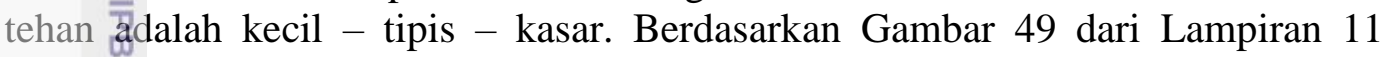
menunjukkan bahwa tanaman semak mampu mengurangi kebisingan pada frekueñsi $200 \mathrm{~Hz}, 250 \mathrm{~Hz}, 315 \mathrm{~Hz}, 1000 \mathrm{~Hz}, 1250 \mathrm{~Hz}, 1600 \mathrm{~Hz}, 2000 \mathrm{~Hz}$, dan 8000 售z, dimana nilai IL $\geq 3 \mathrm{~dB}$.
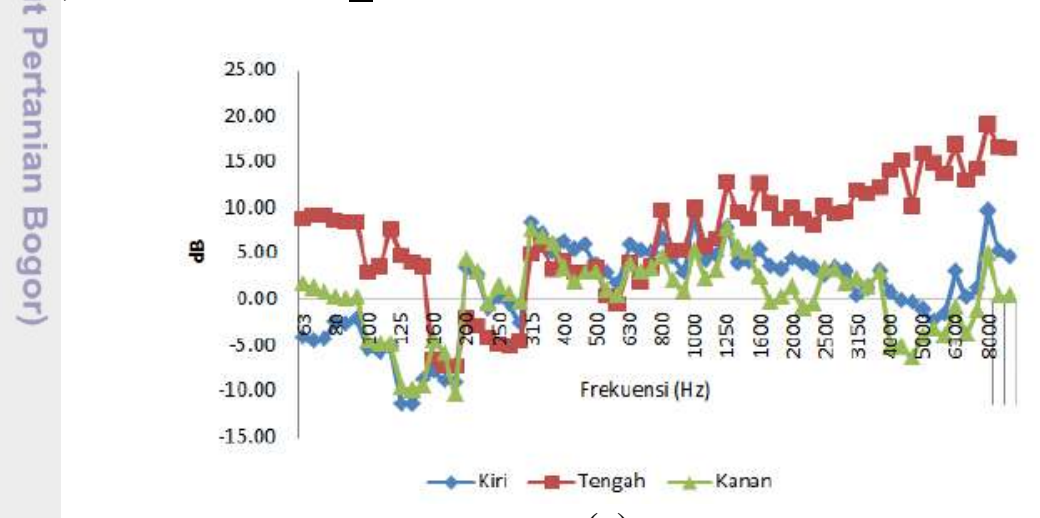

(a)

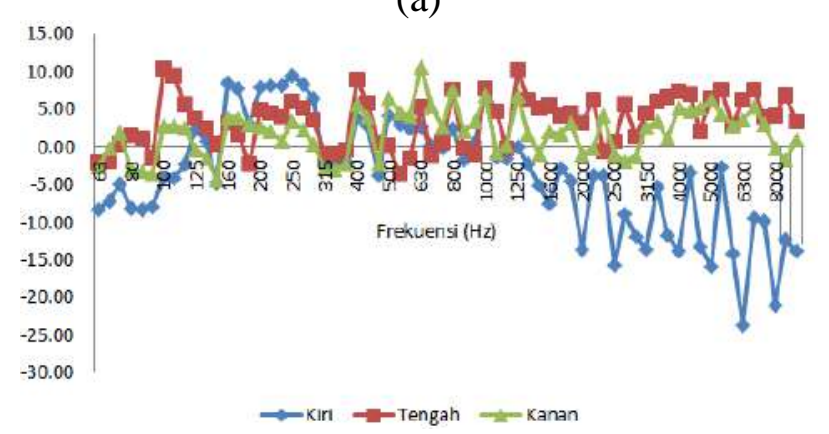

(b)

Gambar 49 IL semak susunan bentuk jalur pada (a) frame 1 (b) frame 2

Lampiran 11 menunjukkan pada frame 1 susunan semak mereduksi bising pada frekuensi $315 \mathrm{~Hz}, 1000 \mathrm{~Hz}, 1250 \mathrm{~Hz}, 1600 \mathrm{~Hz}, 2000 \mathrm{~Hz}$, dan $8000 \mathrm{~Hz}$, sedangkan pada frame 2 susunan semak mereduksi bising pada frekuensi $200 \mathrm{~Hz}$ dan $250 \mathrm{~Hz}$. Gambar 50 menunjukkan bahwa pada kedua frame menunjukkan perbedaan penggunaan tanaman sehingga walaupun jumlah semak untuk kedua frame sama, 
namun susunan tanaman pucuk merah terlihat lebih rapat dibandingkan dengan tanaman teh-tehan. Tanaman pucuk merah memiliki karakteristik yang lebih rimbun dibandingkan dengan tanaman teh-tehan, sehingga tanaman pucuk merah mampu untuk mereduksi pada frekuensi tinggi dibandingkan tanaman teh-tehan.
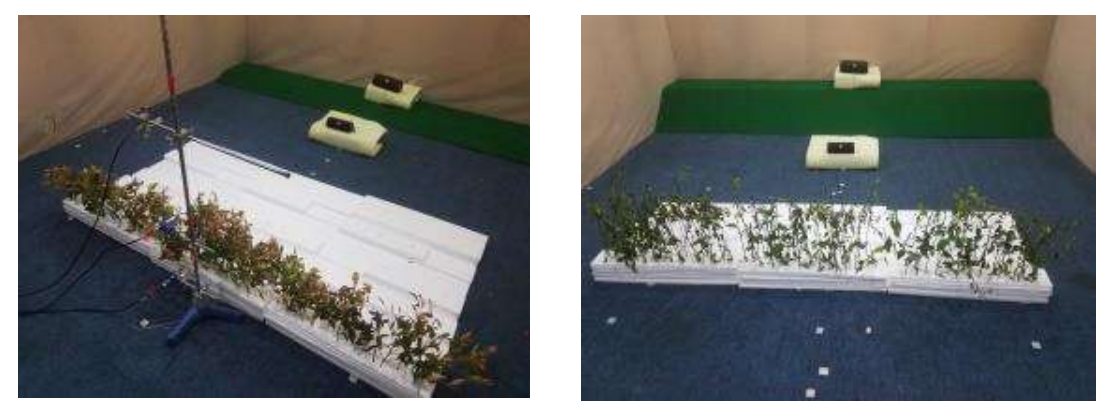

Gambar 50 Penyusunan semak berbentuk jalur

Pada frekuensi $200 \mathrm{~Hz}$ memiliki nilai IL sebesar $8.15 \mathrm{~dB}$, frekuensi $250 \mathrm{~Hz}$ 䎡emiliki nilai IL sebesar $9.55 \mathrm{~dB}$, frekuensi $315 \mathrm{~Hz}$ memiliki nilai IL sebesar $8.17 \mathrm{~dB}$, frekuensi $1000 \mathrm{~Hz}$ memiliki nilai IL sebesar $9.90 \mathrm{~dB}$, frekuensi $1250 \mathrm{~Hz}$ memiliki nilai IL sebesar $12.84 \mathrm{~dB}$, frekuensi $1600 \mathrm{~Hz}$ memiliki nilai IL sebesar 2.59 dB, frekuensi $2000 \mathrm{~Hz}$ memiliki nilai IL sebesar $9.91 \mathrm{~dB}$, dan frekuensi $8000 \mathrm{~Hz}$ memiliki nilai IL sebesar $19.10 \mathrm{~dB}$. Dengan kata lain susunan semak berbentuk jalur sangat efektif mereduksi bising hingga $11.27 \%$, sehingga dapat disimpulkan bahwa susunan semak berbentuk jalur sangat efektif mereduksi bising pada frekuensi rendah dan tinggi apabila kedua sumber suara berada pada level ketinggian yang tidak berbeda jauh, serta dengan menggunakan tanaman fang rimbun (pucuk merah). Akan tetapi, apabila kedua sumber suara berada pada tevel ketinggian yang berbeda dan menggunakan tanaman yang tidak terlalu rimbun (teh-tehan) maka susunan semak berbentuk jalur efektif mereduksi bising pada frekuensi rendah.

c. Kombinasi pohon dan semak

Kombinasi pohon dan semak yang digunakan dalam model penyusunan berbentuk jalur ini adalah kombinasi antara pohon damar (Agathis dammara Lamb.) dan semak pucuk merah (Syzygium oleana Br.Ex) pada frame 1, serta kombinasi pohon damar (Agathis dammara Lamb.) dan semak teh-tehan (Acalypha siamensis Oliv. ex Gage) pada frame 2. Tanaman pohon damar memiliki karakteristik daun sedang - tebal - halus, tanaman pucuk merah memiliki karakteristik daun sedang - tipis - halus, dan tanaman teh-tehan memiliki karakteristik daun sedang - tipis - kasar. Dari kedua kombinasi tanaman tersebut dapat dilihat Gambar 51 dari Lampiran 12 bahwa kombinasi kedua tanaman tersebut mampu mereduksi bising pada frekuensi $630 \mathrm{~Hz}, 2500 \mathrm{~Hz}$, dan $(8000 \mathrm{~Hz}$, dimana nilai IL $\geq 3 \mathrm{~dB}$. 


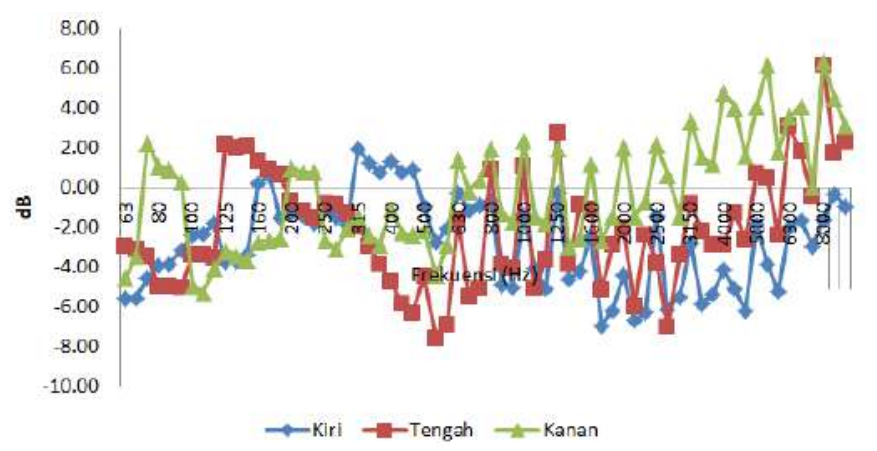

(a)

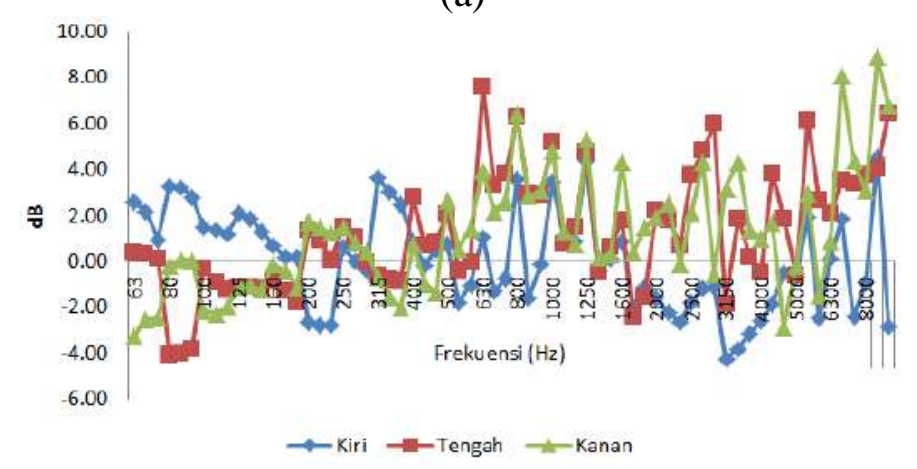

(b)

Gambar 51 IL kombinasi susunan bentuk jalur pada (a) frame 1 (b) frame 2

Pada fampiran 12, dapat dilihat pada frame 1 kombinasi kedua tanaman mereduีkssi bising pada frekuensi $8000 \mathrm{~Hz}$, sedangkan pada frame 2, kombinasi tanaman di titik tengah mereduksi bising pada frekuensi $630 \mathrm{~Hz}, 2500 \mathrm{~Hz}$, dan 8000 远z.
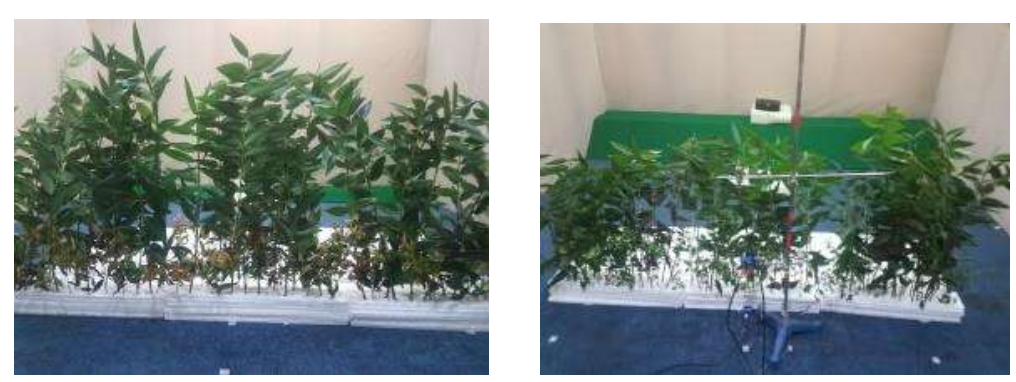

Gambar 52 Penyusunan kombinasi tanaman berbentuk jalur

Pada frekuensi $630 \mathrm{~Hz}$ memiliki nilai IL sebesar $7.64 \mathrm{~dB}$, frekuensi $2500 \mathrm{~Hz}$ memiliki nilai IL sebesar $5.98 \mathrm{~dB}$, dan frekuensi $8000 \mathrm{~Hz}$ memiliki nilai IL sebesar $8.90 \mathrm{~dB}$. Hal ini berarti susunan kombinasi pohon dan semak dengan pola bentuk jalur efektif mereduksi bising hingga 7.56\%. Dari penjelasan kedua frame tersebut, apabila kedua sumber suara berada pada level ketinggian yang tidak berbeđa jauh maka kombinasi tanaman pohon dan semak efektif mereduksi bising pada frekuensi tinggi. Akan tetapi, kombinasi tanaman semak dan pohon efektif untuk-mereduksi bising pada frekuensi rendah dan tinggi apabila kedua sumber suaratberada pada level ketinggian yang berbeda. 
Nilai insertion loss pada ketiga pola penyusunan tanaman

Ketiga pola penyusunan tanaman memiliki nilai IL yang berbeda-beda. Tanaman pohon mampu mereduksi bising pada frekuensi tinggi, sedangkan untuk tanaman semak mampu mereduksi bising pada frekuensi rendah dan tinggi. Berikut kesimpulan nilai IL dari ketiga model perlakuan penyusunan tanaman dapat dilihat pada Tabel 18.

Tabel 18 Nilai IL dari ketiga model penyusunan tanaman

\begin{tabular}{|c|c|c|c|c|c|c|c|c|c|}
\hline & & & & & Nilai IL & & & & \\
\hline & (O) & Titik kiri & & & Titik tenga & & & Titik kana & \\
\hline & $I \mathrm{M} 1$ & M2 & M3 & M1 & M2 & M3 & M1 & M2 & M3 \\
\hline 7 & Pohon b & xelompok & & & & & & & \\
\hline 5000 & $-\mathrm{E} .57 \bullet$ & $-2.36 \bullet$ & $-3.28 \bullet$ & $6.20 \bullet$ & $11.11 \bullet$ & $9.44 \bullet$ & $4.30 \bullet$ & $3.90 \bullet$ & $5.59 \bullet$ \\
\hline$\frac{0}{2}$ & $1.66 \bullet \bullet$ & $5.36 \bullet \bullet$ & $2.04 \bullet \bullet$ & $2.13 \bullet \bullet$ & $8.45 \bullet \bullet$ & $6.92 \bullet \bullet$ & $1.39 \bullet \bullet$ & $4.28 \bullet \bullet$ & $2.59 \bullet \bullet$ \\
\hline б300 & $-0.94 \bullet$ & $2.38 \bullet$ & $-2.21 \bullet$ & $8.84 \bullet$ & $9.64 \bullet$ & $8.89 \bullet$ & $1.19 \bullet$ & $5.42 \bullet$ & $2.48 \bullet$ \\
\hline & 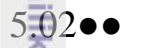 & $8.10 \bullet \bullet$ & $5.14 \bullet \bullet$ & $7.15 \bullet \bullet$ & $12.10 \bullet \bullet$ & $9.87 \bullet \bullet$ & $3.31 \bullet \bullet$ & $6.26 \bullet \bullet$ & $5.13 \bullet \bullet$ \\
\hline 8000 & $-\hat{2} .28 \bullet$ & $2.23 \bullet$ & $-1.27 \bullet$ & $9.49 \bullet$ & $12.99 \bullet$ & $11.59 \bullet$ & $3.20 \bullet$ & $7.84 \bullet$ & $5.50 \bullet$ \\
\hline & 6010 • & $6.49 \bullet \bullet$ & $7.34 \bullet \bullet$ & $9.59 \bullet \bullet$ & $13.42 \bullet \bullet$ & $12.37 \bullet \bullet$ & $1.57 \bullet \bullet$ & $10.61 \bullet \bullet$ & $7.45 \bullet \bullet$ \\
\hline & Semak b & kelompok & & & & & & & \\
\hline 63 & $6.60 \bullet$ & $6.06 \bullet$ & $5.20 \bullet$ & $4.10 \bullet$ & $3.96 \bullet$ & $3.74 \bullet$ & $1.31 \bullet$ & $0.68 \bullet$ & $-0.03 \bullet$ \\
\hline & $-\overline{3} 89 \bullet \bullet$ & $-2.90 \bullet \bullet$ & $-0.79 \bullet \bullet$ & $-4.18 \bullet \bullet$ & $-3.87 \bullet \bullet$ & $-0.79 \bullet \bullet$ & $-6.90 \bullet \bullet$ & $-4.87 \bullet \bullet$ & $-2.15 \bullet \bullet$ \\
\hline 200 & $4.34 \bullet$ & $4.04 \bullet$ & $0.00 \bullet$ & $-2.19 \bullet$ & $-3.13 \bullet$ & $-4.72 \bullet$ & $4.95 \bullet$ & $3.51 \bullet$ & $0.66 \bullet$ \\
\hline & $5.94 \bullet \bullet$ & $6.26 \bullet \bullet$ & $6.42 \bullet \bullet$ & $5.52 \bullet \bullet$ & $5.34 \bullet \bullet$ & $5.05 \bullet \bullet$ & $-0.87 \bullet \bullet$ & $-1.54 \bullet \bullet$ & $-2.85 \bullet \bullet$ \\
\hline 250 & $-0.54 \bullet$ & $-1.52 \bullet$ & $-3.30 \bullet$ & $-3.41 \bullet$ & $-3.54 \bullet$ & $-3.61 \bullet$ & $0.38 \bullet$ & $-0.29 \bullet$ & $-0.95 \bullet$ \\
\hline & $6 \overline{8} 1 \bullet \bullet$ & $5.80 \bullet \bullet$ & $4.18 \bullet \bullet$ & $7.43 \bullet \bullet$ & $6.39 \bullet \bullet$ & $4.69 \bullet \bullet$ & $3.78 \bullet \bullet$ & $2.96 \bullet \bullet$ & $1.49 \bullet \bullet$ \\
\hline 315 & $2.80 \bullet$ & $0.83 \bullet$ & $-1.32 \bullet$ & $8.85 \bullet$ & $8.90 \bullet$ & $5.41 \bullet$ & $6.31 \bullet$ & $5.28 \bullet$ & $4.49 \bullet$ \\
\hline & $-376 \bullet \bullet$ & $-3.76 \bullet \bullet$ & $-3.61 \bullet \bullet$ & $2.93 \bullet \bullet$ & $3.07 \bullet \bullet$ & $3.96 \bullet \bullet$ & $0.59 \bullet$ & $0.35 \bullet \bullet$ & $1.13 \bullet \bullet$ \\
\hline 1000 & $9.98 \bullet$ & $5.31 \bullet$ & $5.53 \bullet$ & $8.76 \bullet$ & $4.96 \bullet$ & $5.16 \bullet$ & $3.12 \bullet$ & $0.02 \bullet$ & $1.05 \bullet$ \\
\hline & $4.09 \bullet \bullet$ & $-3.22 \bullet \bullet$ & $-3.35 \bullet \bullet$ & $4.95 \bullet \bullet$ & $2.12 \bullet \bullet$ & $-2.62 \bullet \bullet$ & $5.05 \bullet \bullet$ & $-0.97 \bullet \bullet$ & $-0.15 \bullet \bullet$ \\
\hline 1250 & $9.89 \bullet$ & $6.35 \bullet$ & $6.68 \bullet$ & $9.12 \bullet$ & $6.17 \bullet$ & $3.93 \bullet$ & $7.31 \bullet$ & $4.90 \bullet$ & $4.74 \bullet$ \\
\hline & $-1.93 \bullet \bullet$ & $-5.10 \bullet \bullet$ & $-7.32 \bullet \bullet$ & $7.25 \bullet \bullet$ & $4.36 \bullet \bullet$ & $2.57 \bullet \bullet$ & $5.99 \bullet \bullet$ & $2.06 \bullet \bullet$ & $-0.79 \bullet \bullet$ \\
\hline 1600 & $8.16 \bullet$ & $6.85 \bullet$ & $5.96 \bullet$ & $10.67 \bullet$ & $8.94 \bullet$ & $6.92 \bullet$ & $3.46 \bullet$ & $1.15 \bullet$ & $2.01 \bullet$ \\
\hline & $-7.57 \bullet \bullet$ & $-5.22 \bullet \bullet$ & $-6.62 \bullet \bullet$ & $3.14 \bullet \bullet$ & $2.37 \bullet \bullet$ & $3.07 \bullet \bullet$ & $2.09 \bullet \bullet$ & $1.58 \bullet \bullet$ & $3.33 \bullet \bullet$ \\
\hline 2000 & $5.86 \bullet$ & $6.53 \bullet$ & $5.19 \bullet$ & $8.01 \bullet$ & $7.39 \bullet$ & $6.75 \bullet$ & $1.99 \bullet$ & $0.14 \bullet$ & $0.57 \bullet$ \\
\hline & $-8.58 \bullet \bullet$ & $-5.30 \bullet \bullet$ & $-4.31 \bullet \bullet$ & $0.71 \bullet \bullet$ & $4.01 \bullet \bullet$ & $-2.77 \bullet \bullet$ & $-0.63 \bullet \bullet$ & $0.58 \bullet \bullet$ & $4.85 \bullet \bullet$ \\
\hline 2500 & $3.97 \bullet$ & $7.01 \bullet$ & $5.62 \bullet$ & $5.98 \bullet$ & $6.98 \bullet$ & $6.89 \bullet$ & $1.33 \bullet$ & $1.74 \bullet$ & $1.20 \bullet$ \\
\hline & $-6.55 \bullet \bullet$ & $-7.73 \bullet \bullet$ & $-7.59 \bullet \bullet$ & $-2.19 \bullet \bullet$ & $3.64 \bullet \bullet$ & $-1.43 \bullet \bullet$ & $-1.83 \bullet \bullet$ & $-2.36 \bullet \bullet$ & $-1.60 \bullet \bullet$ \\
\hline 8000 & $9.55 \bullet$ & $5.46 \bullet$ & $5.08 \bullet$ & $18.55 \bullet$ & $13.79 \bullet$ & $13.06 \bullet$ & $5.61 \bullet$ & $1.81 \bullet$ & $1.36 \bullet$ \\
\hline & $0.38 \bullet \bullet$ & $-0.70 \bullet \bullet$ & $0.46 \bullet \bullet$ & $2.88 \bullet \bullet$ & $3.30 \bullet \bullet$ & $0.05 \bullet \bullet$ & $1.77 \bullet \bullet$ & $0.58 \bullet \bullet$ & $2.74 \bullet \bullet$ \\
\hline & Kombin & berkelom & ok & & & & & & \\
\hline 160 & $1.11 \bullet$ & $1.48 \bullet$ & $2.51 \bullet$ & $3.41 \bullet$ & $3.31 \bullet$ & $3.50 \bullet$ & $0.84 \bullet$ & $1.22 \bullet$ & $2.98 \bullet$ \\
\hline & $3.69 \bullet \bullet$ & $2.72 \bullet \bullet$ & $2.11 \bullet \bullet$ & $-2.02 \bullet \bullet$ & $-2.54 \bullet \bullet$ & $-3.54 \bullet \bullet$ & $-1.06 \bullet \bullet$ & $-1.44 \bullet \bullet$ & $-2.20 \bullet \bullet$ \\
\hline 8000 & $1.28 \bullet$ & $4.14 \bullet$ & $-0.06 \bullet$ & $1.28 \bullet$ & $4.61 \bullet$ & $3.36 \bullet$ & $5.86 \bullet$ & $2.85 \bullet$ & $1.26 \bullet$ \\
\hline & $1.15 \bullet \bullet$ & $4.58 \bullet \bullet$ & $-1.33 \bullet \bullet$ & $9.16 \bullet \bullet$ & $10.50 \bullet \bullet$ & $10.41 \bullet \bullet$ & $5.49 \bullet \bullet$ & $10.19 \bullet \bullet$ & $4.91 \bullet \bullet$ \\
\hline
\end{tabular}


Tabel 18 Nilai IL dari ketiga model penyusunan tanaman (lanjutan)

\begin{tabular}{|c|c|c|c|c|c|c|c|c|c|}
\hline \multirow{4}{*}{ 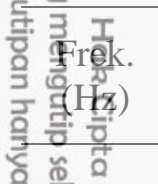 } & \multicolumn{9}{|c|}{ Nilai IL } \\
\hline & \multicolumn{3}{|c|}{ Titik kiri } & \multicolumn{3}{|c|}{ Titik tengah } & \multicolumn{3}{|c|}{ Titik kanan } \\
\hline & M1 & M2 & M3 & M1 & M2 & M3 & M1 & M2 & M3 \\
\hline & & & & & & & & & \\
\hline 正 & \multicolumn{9}{|c|}{ Pohon menyebar } \\
\hline & $4.10 \bullet$ & $4.12 \bullet$ & $4.15 \bullet$ & $3.73 \bullet$ & $3.75 \bullet$ & $4.35 \bullet$ & $-0.78 \bullet$ & $-0.91 \bullet$ & $-0.97 \bullet$ \\
\hline & $3.95 \bullet \bullet$ & $3.92 \bullet \bullet$ & $3.94 \bullet \bullet$ & $-1.59 \bullet \bullet$ & $-1.57 \bullet \bullet$ & $-1.72 \bullet \bullet$ & $0.58 \bullet \bullet$ & $0.65 \bullet \bullet$ & $0.93 \bullet \bullet$ \\
\hline 50 & 8.380 & $5.60 \bullet$ & $3.81 \bullet$ & $5.61 \bullet$ & $8.73 \bullet$ & $5.27 \bullet$ & $2.61 \bullet$ & $0.57 \bullet$ & $-0.58 \bullet$ \\
\hline & -2.560 & $2.93 \bullet \bullet$ & $2.26 \bullet \bullet$ & $-0.39 \bullet \bullet$ & $2.32 \bullet \bullet$ & $2.64 \bullet \bullet$ & $-0.16 \bullet \bullet$ & $-0.92 \bullet \bullet$ & $-1.05 \bullet \bullet$ \\
\hline fe) & $6.16 \bar{\varnothing}$ & $6.76 \bullet$ & $5.75 \bullet$ & $6.18 \bullet$ & $11.28 \bullet$ & $8.70 \bullet$ & $-1.85 \bullet$ & $2.42 \bullet$ & $-1.51 \bullet$ \\
\hline & $3.18 \div 0$ & $4.17 \bullet \bullet$ & $0.44 \bullet \bullet$ & $-1.51 \bullet \bullet$ & $5.35 \bullet \bullet$ & $-0.18 \bullet \bullet$ & $-1.51 \bullet \bullet$ & $0.12 \bullet \bullet$ & $-4.44 \bullet \bullet$ \\
\hline (aff) & $4.68 \hat{8}$ & $6.91 \bullet$ & $5.36 \bullet$ & $9.50 \bullet$ & $11.49 \bullet$ & $8.68 \bullet$ & $1.99 \bullet$ & $3.22 \bullet$ & $1.26 \bullet$ \\
\hline & 2.8700 & $5.97 \bullet \bullet$ & $4.74 \bullet \bullet$ & $-0.09 \bullet \bullet$ & $3.75 \bullet \bullet$ & $2.28 \bullet \bullet$ & $-3.71 \bullet \bullet$ & $2.46 \bullet \bullet$ & $-2.23 \bullet \bullet$ \\
\hline & $5.05 \overline{\underline{\mathbf{z}}}$ & $7.71 \bullet$ & $5.01 \bullet$ & $8.63 \bullet$ & $10.14 \bullet$ & $9.02 \bullet$ & $2.98 \bullet$ & $2.82 \bullet$ & $4.16 \bullet$ \\
\hline & $6.45 \overline{\overline{00}}$ & $9.53 \bullet \bullet$ & $6.87 \bullet \bullet$ & $2.17 \bullet \bullet$ & $6.91 \bullet \bullet$ & $7.42 \bullet \bullet$ & $1.45 \bullet \bullet$ & $3.19 \bullet \bullet$ & $0.76 \bullet \bullet$ \\
\hline & $1 \hat{8}$ & $9.50 \bullet$ & $7.08 \bullet$ & $10.26 \bullet$ & $10.82 \bullet$ & $12.31 \bullet$ & $2.01 \bullet$ & $6.89 \bullet$ & $5.45 \bullet$ \\
\hline & 8.9700 & $12.06 \bullet \bullet$ & $8.08 \bullet \bullet$ & $6.01 \bullet \bullet$ & $6.59 \bullet \bullet$ & $5.40 \bullet \bullet$ & $1.18 \bullet \bullet$ & $5.64 \bullet \bullet$ & $1.61 \bullet \bullet$ \\
\hline & \multicolumn{9}{|c|}{ Semâk menyebar } \\
\hline 15 & 7.240 & $6.13 \bullet$ & $4.41 \bullet$ & $8.12 \bullet$ & $8.20 \bullet$ & $4.54 \bullet$ & $8.25 \bullet$ & $7.06 \bullet$ & $6.14 \bullet$ \\
\hline & -1.590 & $-1.54 \bullet \bullet$ & $-1.41 \bullet \bullet$ & $1.88 \bullet \bullet$ & $2.08 \bullet \bullet$ & $2.53 \bullet \bullet$ & $0.23 \bullet \bullet$ & $-0.05 \bullet \bullet$ & $0.65 \bullet \bullet$ \\
\hline & $1.93 \not$ & $1.63 \bullet$ & $-1.81 \bullet$ & $0.71 \bullet$ & $-0.40 \bullet$ & $-2.28 \bullet$ & $3.43 \bullet$ & $2.26 \bullet$ & $-0.49 \bullet$ \\
\hline & $4.48 \%$ & $4.99 \bullet \bullet$ & $5.61 \bullet \bullet$ & $9.16 \bullet \bullet$ & $8.96 \bullet \bullet$ & $8.60 \bullet \bullet$ & $2.11 \bullet \bullet$ & $1.59 \bullet \bullet$ & $0.37 \bullet \bullet$ \\
\hline 0 & $1.62 \overline{0}$ & $0.91 \bullet$ & $-1.08 \bullet$ & $-0.93 \bullet$ & $-1.03 \bullet$ & $-1.22 \bullet$ & $2.11 \bullet$ & $1.37 \bullet$ & $0.66 \bullet$ \\
\hline & 7.79 อొ & $7.03 \bullet \bullet$ & $5.65 \bullet \bullet$ & $9.45 \bullet \bullet$ & $8.45 \bullet \bullet$ & $6.67 \bullet \bullet$ & $2.51 \bullet \bullet$ & $1.91 \bullet \bullet$ & $1.07 \bullet \bullet$ \\
\hline & 4.150 & $3.48 \bullet$ & $4.22 \bullet$ & $4.22 \bullet$ & $3.94 \bullet$ & $4.96 \bullet$ & $5.10 \bullet$ & $3.55 \bullet$ & $4.31 \bullet$ \\
\hline & 4.5500 & $2.95 \bullet \bullet$ & $-3.23 \bullet \bullet$ & $9.40 \bullet \bullet$ & $6.53 \bullet \bullet$ & $1.00 \bullet \bullet$ & $6.11 \bullet \bullet$ & $4.69 \bullet \bullet$ & $-0.59 \bullet \bullet$ \\
\hline 50 & $6.11 e^{\circ}$ & $2.36 \bullet$ & $2.66 \bullet$ & $7.70 \bullet$ & $4.67 \bullet$ & $3.44 \bullet$ & $8.40 \bullet$ & $6.07 \bullet$ & $5.64 \bullet$ \\
\hline & $0.19 \bullet \bullet$ & $-2.35 \bullet \bullet$ & $-4.85 \bullet \bullet$ & $7.02 \bullet \bullet$ & $3.29 \bullet \bullet$ & $1.79 \bullet \bullet$ & $4.87 \bullet \bullet$ & $1.30 \bullet \bullet$ & $-1.13 \bullet \bullet$ \\
\hline 5 & $9.74 \bullet$ & $5.06 \bullet$ & $3.56 \bullet$ & $7.33 \bullet$ & $3.12 \bullet$ & $3.84 \bullet$ & $3.70 \bullet$ & $2.84 \bullet$ & $3.41 \bullet$ \\
\hline & $-7.88 \bullet \bullet$ & $-8.26 \bullet \bullet$ & $-6.56 \bullet \bullet$ & $1.88 \bullet \bullet$ & $1.37 \bullet \bullet$ & $0.00 \bullet \bullet$ & $4.12 \bullet \bullet$ & $3.10 \bullet \bullet$ & $5.23 \bullet \bullet$ \\
\hline & \multicolumn{9}{|c|}{ Kombinasi menyebar } \\
\hline 0 & $0.16 \bullet$ & $-0.16 \bullet$ & $-0.80 \bullet$ & $-0.43 \bullet$ & $-0.75 \bullet$ & $-1.25 \bullet$ & $3.62 \bullet$ & $3.26 \bullet$ & $3.20 \bullet$ \\
\hline & $0.69 \bullet \bullet$ & $0.44 \bullet \bullet$ & $0.27 \bullet \bullet$ & $1.31 \bullet \bullet$ & $0.96 \bullet \bullet$ & $0.54 \bullet \bullet$ & $0.45 \bullet \bullet$ & $0.30 \bullet \bullet$ & $0.16 \bullet \bullet$ \\
\hline & $-1.40 \bullet$ & $-2.34 \bullet$ & $-2.32 \bullet$ & $2.58 \bullet$ & $-0.77 \bullet$ & $-0.06 \bullet$ & $0.24 \bullet$ & $-1.53 \bullet$ & $-1.21 \bullet$ \\
\hline & $0.10 \bullet \bullet$ & $-2.54 \bullet \bullet$ & $-1.54 \bullet \bullet$ & $8.22 \bullet \bullet$ & $4.02 \bullet \bullet$ & $3.54 \bullet \bullet$ & $-0.79 \bullet \bullet$ & $-2.74 \bullet \bullet$ & $-1.96 \bullet \bullet$ \\
\hline & $0.79 \bullet$ & $-3.34 \bullet$ & $-4.05 \bullet$ & $2.63 \bullet$ & $-1.80 \bullet$ & $-1.84 \bullet$ & $1.28 \bullet$ & $-2.04 \bullet$ & $-2.91 \bullet$ \\
\hline & $1.00 \bullet \bullet$ & $-4.31 \bullet \bullet$ & $-2.94 \bullet \bullet$ & $7.91 \bullet \bullet$ & $4.72 \bullet \bullet$ & $4.53 \bullet \bullet$ & $3.34 \bullet \bullet$ & $-0.86 \bullet \bullet$ & $-0.37 \bullet \bullet$ \\
\hline & -5.040 & $-5.79 \bullet$ & $-7.48 \bullet$ & $-0.27 \bullet$ & $5.97 \bullet$ & $0.07 \bullet$ & $-0.22 \bullet$ & $2.16 \bullet$ & $1.68 \bullet$ \\
\hline & 1.3600 & $2.97 \bullet \bullet$ & $2.64 \bullet \bullet$ & $5.43 \bullet \bullet$ & $8.14 \bullet \bullet$ & $5.37 \bullet \bullet$ & $1.55 \bullet \bullet$ & $4.49 \bullet \bullet$ & $1.56 \bullet \bullet$ \\
\hline & -6.720 & $-7.01 \bullet$ & $-6.96 \bullet$ & $-0.54 \bullet$ & $4.64 \bullet$ & $2.70 \bullet$ & $3.53 \bullet$ & $5.18 \bullet$ & $2.08 \bullet$ \\
\hline & 0.440 & $1.57 \bullet \bullet$ & $1.42 \bullet \bullet$ & $4.19 \bullet \bullet$ & $6.79 \bullet \bullet$ & $5.21 \bullet \bullet$ & $1.32 \bullet \bullet$ & $5.45 \bullet \bullet$ & $1.78 \bullet \bullet$ \\
\hline
\end{tabular}

Keterangan:

$\bullet=$ frame $1, \bullet \bullet=$ frame 2

$\mathrm{M} 1$ = Mic bagian bawah, M2 = mic bagian tengah, $\mathrm{M} 3=$ mic bagian atas 
Tabel 18 Nilai IL dari ketiga model penyusunan tanaman (lanjutan)

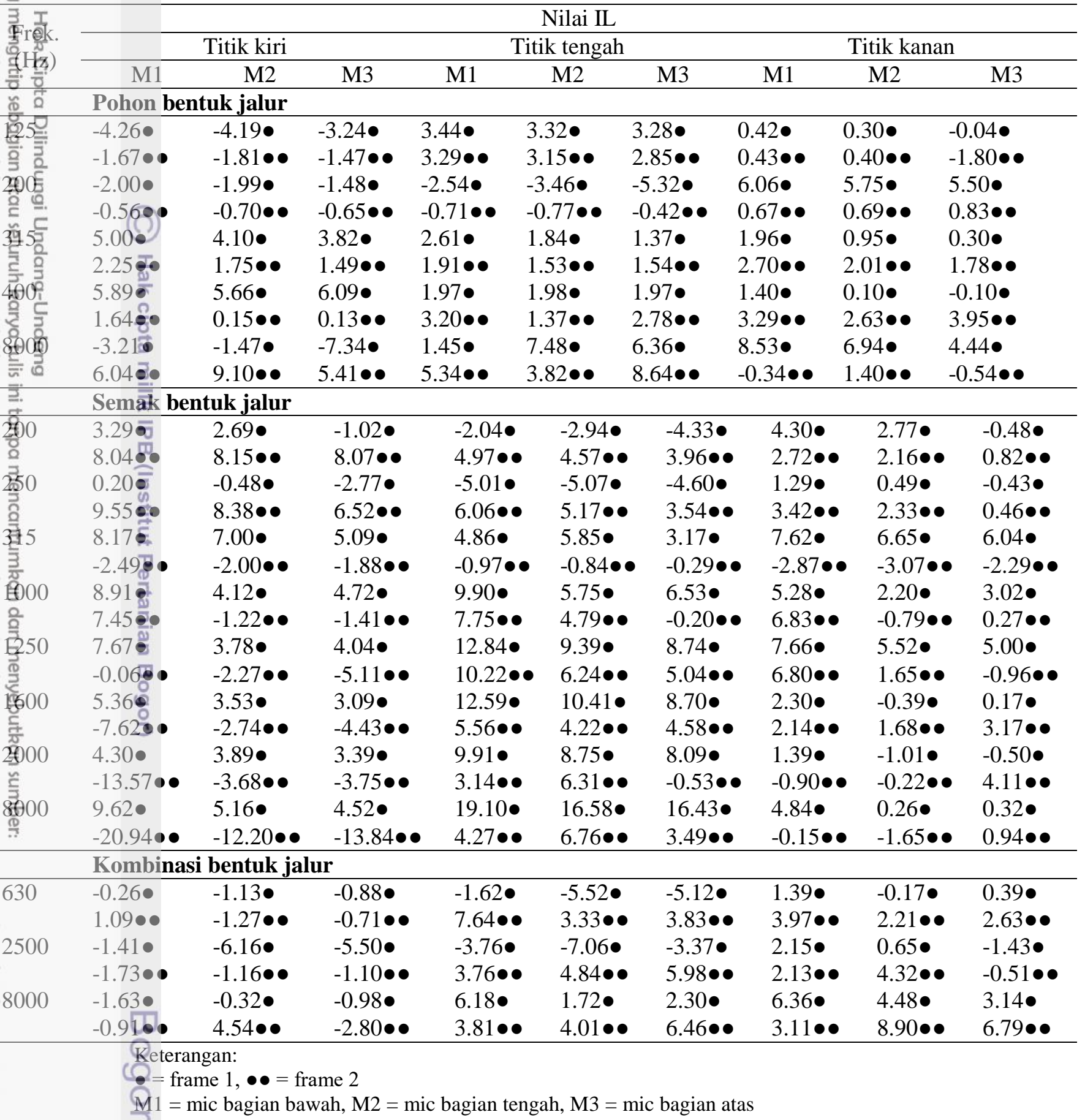

Berdasarkan penelitian simulasi yang ditunjukkan pada Tabel 18, dapat dilihat bahwa masing-masing jenis tanaman memiliki kemampuan yang berbeda dalam mereduksi kebisingan berdasarkan tingkatan frekuensi. Pohon damar (Agathis dammara Lamb.) mampu mengurangi bising pada semua tingkatan frekuensi, khususnya pada frekuensi rentang frekuensi $5000 \mathrm{~Hz}-8000 \mathrm{~Hz}$ (frekuensi tinggi). Sementara itu, semak pucuk merah (Syzygium oleana Br.Ex) mampu mengurangi pada semua tingkatan frekuensi, khususnya pada rentang frekuensi $315 \mathrm{~Hz}-8000 \mathrm{~Hz}$. Kemudian, untuk semak teh-tehan (Acalypha 
siamensis Oliv. ex Gage) mampu mengurangi bising pada frekuensi rendah, khususnya frekuensi $200 \mathrm{~Hz}$ dan $250 \mathrm{~Hz}$. Nilai minus pada IL menunjukkan bahwa suara loss terhadap barrier atau dengan kata lain suara tidak dapat direduksi oleh barrier tanaman. Posisi daun-daun pada ketiga jenis tanaman tersebut menghadap ke berbagai arah dan tidak seragam ke satu arah. Posisi daun terhadap arah datang bunyi dan antar daun memungkinkan gelombang frekuensi tinggi dipantulkan dan disebarkan, sedangkan gelombang frekuensi rendah mengalami pembelokkan dan menembus ruang antar daun tanaman. Sesuai dengan pernyataan Widagdo (1998) bahwa pemantulan, penyerapan, penyebaran, pembelokkan, dan penerusan bunyi oleh daun dipengaruhi oleh ketebalan daun, kerapatan daun, sudut daun terhadap arah datang suara, dan posisi hadap antar daun.

Ealam penelitian ini juga diperlihatkan bahwa tanaman pucuk merah memiliki kemampuan mereduksi bising lebih besar dibandingkan dengan tanaman damar dan teh-tehan. Pohon damar sangat efektif mengurangi bising hingga 13.42 $\mathrm{dB}$, semak pucuk merah sangat efektif mengurangi bising hingga $19.10 \mathrm{~dB}$, serta semak dapat diketahui bahwa kemampuan tanaman mereduksi bising dipengaruhi oleh ketebalan dan kelenturan daun. Ketebalan dan kelenturan daun berkaitan dengan kemudầhan daun untuk bergerak. Gerakan daun dapat menyebabkan perubahan posisi -antar daun sehingga mempengaruhi ruang antar daun (Widagdo 1998). Tanaman damar memiliki daun yang tebal dan kaku sehingga mampu mereduksi bising pada frekuensi tinggi dibandingkan dengan tanaman pucuk merah dan tehtehan $y^{\prime}$ ang berdaun lebih tipis dan lentur. Setiap spesies tanaman memiliki efektivitas yang berbeda dalam mereduksi bising karena adanya perbedaan karakter tiap spesies tanaman.

\section{Perumusan Rekomendasi}

Kawasan perumahan seharusnya dapat dijadikan lingkungan tempat tinggal yang dapat memberikan kenyamanan bagi penduduknya. Kenyamanan dapat mempengaruhi perilaku manusia atau dapat memberikan pengaruh secara psikologis. Menurut Adrian (2015), kriteria dari lingkungan rumah yang ideal adalah lingkungan sekitar memiliki hubungan yang baik dengan tetangga, kepadatan bangunan tidak padat (tidak kumuh), tingkat kebisingan rendah, memiliki udara sejuk, memiliki lingkungan asri, dan terhindar dari banjir. Salah satu permasalahan lingkungan perumahan saat ini adalah kebisingan. Sumber kebisingan yang dominan di lingkungan perumahan berasal dari lalu lintas kendaraan bermotor. Penyebab kebisingan di lingkungan perumahan dapat ditanđai dengan penyediaan prasarana jalan yang menjadikan lingkungan perunahan menjadi jalan pintas dari dan ke jalan umum, kemudian ditambah dengan-adanya sarana pertambahan kepadatan lalu lintas akan semakin menimbulkan kebisingan di lingkungan perumahan.

Rekomendasi upaya pengendalian bising di lingkungan perumahan dapat dilakukan pendekatan pada sumber suara, penerima, maupun pada medium perantara sumber dan penerima suara, dalam hal penelitian ini medium perantara yang dimaksud adalah penghalang (barrier). Upaya pendekatan pengurangan 
bising pada sumber suara dapat dilakukan dengan manajemen lalu lintas, seperti mengurangi volume lalu lintas serta diimbangi dengan peningkatan kecepatan lalu lintas (King et al 2011). Apabila kecepatan kendaraan semakin tinggi maka tingkat bising yang diterima tidak berpengaruh, namun apabila kecepatan kendaraan rendah maka tingkat kebisingan akan semakin tinggi, dikarenakan suara mesin akan cenderung mendominasi. Hal ini didukung oleh penjelasan Andersen dalam Murphy dan King (2014), bahwa kecepatan 100 - 130 km/jam, pada kendaraan berat, tidak menimbulkan tingkat kebisingan, pada kendaraan ringan tingkat kebisingan yang dihasilkan bertambah $1.2 \mathrm{~dB}$. Pada kecepatan $30-$ $40 \mathrm{~km} / \mathrm{jam}$, untuk kendaraan berat, tingkat kebisingan bertambah $2.7 \mathrm{~dB}$, namun पెhtuk kendaraan ringan bertambah $3.6 \mathrm{~dB}$.

Usaha pendekatan lainnya, selain manajemen lalu lintas, adalah fremperbaiki permukaan jalan. Permukaan jalan yang efektif dalam mengurangi bising adalah aspal berpori atau aspal lapisan tipis, dengan menggunakan ukuran àgregat kecil antara 6-8 mm (Merska et al 2016). Dengan ukuran agregat ini akan membuat permukaan jalan menjadi halus serta dapat mengurangi bising yang distimbulkan oleh gesekan antara roda kendaraan dan permukaan jalan. Aspal berpori dapat mengurangi kebisingan antara $2 \mathrm{~dB}$ hingga $6 \mathrm{~dB}$ (Bruel dan Kjaer 1988). Aspal berpori dapat menyerap pantulan suara yang dipantulkan dari mesin kendaraan, sehingga lebih cocok digunakan untuk daerah perkotaan. Kedua usaha pendekatan tersebut akan lebih maksimal jika adanya upaya kerjasama antara pemerintah dan masyarakat. Kebijakan dari pemerintah dalam membuat standar peraturan dapat mengendalikan emisi dan pengurangan kebisingan. Studi kasus Bemerintah Thailand mengeluarkan kebijakan dalam menangani kebisingan, seperti tingkat kebisingan di perumahan tidak boleh melebihi $70 \mathrm{~dB}$, sedangkan tontuk area industry tidak melebihi $80 \mathrm{~dB}$ (WHO 1999). Adapun yang dilakukan pemerintah Kota Annecy, Prancis dengan menggunakan sepeda ke sekolah, menggunakan material jalan yang menyerap bising, menyediakan jalur pejalan kaki pada pusat kota, serta mengubah rute jalan (Murphy dan King 2014).

Pada penerima suara (penghuni rumah), usaha pendekatan mengendalikan kebisingan adalah menutup pintu dan jendela pada bangunan rumah. Adapun pada bangunan rumah dapat dilakukan pemasangan dua atau tiga lapis pada kaca jendela (Taherzadeh 2014). Selain itu, dapat menambahkan pepohonan dan water feature kolam ikan atau air mancur di halaman rumah. Pepohonan yang ditanam sebaiknya yang menarik satwa burung. Kicauan burung maupun suara air dapat membantu dalam mengurangi bising di lingkungan perumahan (Hong et al 2017). Pohon yang disukai burung salah satunya adalah pohon peneduh yang dapat dijadikan sumber makanan dan tempat bersarang. Kriteria pohon yang menarik perhatian burung adalah memiliki percabangan yang banyak, seperti pohon kersen (Mutingia calabura), asam jawa (Tamarindus indica), dan kirai payung (Felicium decipiens).

Pada penelitian ini ditemukan contoh halaman rumah yang memiliki pola tanaman berkelompok dan menyebar, dimana penghuni rumah tidak merasakan pengaruh kebisingan dari Perumahan IPB 1 Baranangsiang, padahal tingkat kebisingan pada rumah tersebut mencapai $61.02 \mathrm{~dB}$. Penyusunan tanaman dengan pola tersebut dapat diterapkan pada rumah-rumah lainnya yang terpapar bising untuk mereduksi kebisingan yang dirasakan. Hal ini sesuai dengan pernyataan Trwan (1994), pola penanaman yang efektif dalam mengurangi bising adalah pola 
menyebar berstrata banyak dan bergerombol/kelompok. Pada lingkungan Perumahan IPB 1 Baranangsiang, penduduk perumahan dapat menanam segala jenis pohon yang dapat menarik perhatian satwa burung atau menambah elemen air di halaman rumah sekaligus menjadi keindahan bagi penduduk perumahan tersebut. Pada umumnya, setiap orang menyukai suara alam, sehingga kebisingan yang dihasilkan dari suara kendaraan akan teralihkan oleh suara alam tersebut.

Kemampuan tanaman dalam mereduksi kebisingan dipengaruhi oleh kelenturan dan ketebalan daun. Tanaman pucuk merah memiliki kemampuan mereduksi bising lebih besar dibandingkan dengan tanaman damar dan teh-tehan. Pohon damar sangat efektif mengurangi bising hingga $13.42 \mathrm{~dB}$, semak pucuk merah Tsangat efektif mengurangi bising hingga $19.10 \mathrm{~dB}$, serta semak teh-tehan efektif̌mengurangi bising hingga $9.55 \mathrm{~dB}$. Sementara itu, masing-masing jenis tanamąn memiliki kemampuan yang berbeda dalam mereduksi kebisingan berdasärkan tingkatan frekuensi. Pada penelitian simulasi ini, tanaman damar (Agathî. dammara Lamb.) mampu mereduksi bising pada semua frekuensi, khususnya pada rentang frekuensi tinggi, yaitu $5000 \mathrm{~Hz}-8000 \mathrm{~Hz}$. Kemudian tanama pucuk merah (Syzygium oleana Br.Ex) juga mampu mereduksi bising pada semua frekuensi, khususnya pada rentang frekuensi $315 \mathrm{~Hz}-8000 \mathrm{~Hz}$. Sementara itu, untuk tanaman teh-tehan (Acalypha siamensis Oliv. ex Gage) mamp $\overline{\underline{E}}$ mereduksi pada frekuensi rendah, yaitu frekuensi $200 \mathrm{~Hz}$ dan $250 \mathrm{~Hz}$. Hal ini dapat terjadi dikarenakan posisi daun-daun pada ketiga jenis tanaman tersebut menghadap ke berbagai arah dan tidak seragam ke satu arah. Posisi daun terhadap arah dătang bunyi dan antar daun memungkinkan gelombang frekuensi tinggi dipant빌. dan disebarkan, sedangkan gelombang frekuensi rendah mengalami pembetokkan dan menembus ruang antar daun tanaman. Penjelasan tersebut sesuaio dengan pernyataan Widagdo (1988), bahwa hal ini berkaitan dengan kemudăhan daun untuk bergerak karena angin dan energi suara. Gerakan daun menyebabkan perubahan posisi antar daun sehingga mempengaruhi ruang antar daun. Ruang antar daun memungkinkan suara menembus ke dalam vegetasi yang selanjutnya dipantulkan, diserap, disebarkan, dibelokkan atau diteruskan oleh daun sebagai bidang penahan suara pada vegetasi. Pemantulan, penyerapan, penyebaran, pembelokan, dan penerusan suara oleh daun dipengaruhi oleh ketebalan daun, kerapatan daun, sudut daun terhadap arah datang energi suara, dan posisi antar daun. Tanaman yang dapat berfungsi sebagai peredam kebisingan adalah tanaman pohon atau semak memiliki massa daun padat dan rapat (Hidayat 2010), memiliki daun lebat sepanjang tahun dengan pola daun menyebar hingga ke permukaan tanah (Carpenter et al 1975), selain itu juga memiliki tajuk yang tebal, daun yang ringan, dan bertangkai daun (Fakuara 1986).

Bada area lahan kosong yang terdapat di antara perumahan dan jalan di bagiantimur perumahan tersebut dapat ditanami barrier tanaman dan gundukan tanah. Dari hasil penelitian menunjukkan bahwa tanaman damar, pucuk merah, dan teh-tehan dapat mereduksi kebisingan dengan efektif dan direkomendasikan untuk-dipilih dalam penataan jalur hijau dengan kombinasi yang juga memperhatikan estetika. Pohon damar (Agathis dammara Lamb.) merupakan tanaman yang memiliki ukuran daun sedang, massa daun padat, berdaun tebal, dan memiliki daya tarik bentuk tajuk kerucut. Semak pucuk merah (Syzygium oleana Br.Ex) memiliki karakteristik ukuran daun sedang, rimbun, serta memiliki daya tarik utama pada warna daun. Semak teh-tehan memiliki karakteristik ukuran 
daun sedang, rimbun, dan daya tarik utamanya berada pada warna daun yang hijau mengkilap.

Berdasarkan hasil penelitian, pola penyusunan tanaman yang efektif mereduksi bising adalah pola berbentuk jalur untuk susunan semak dan pola berkelompok untuk susunan pohon. Penyusunan semak berbentuk jalur yang terdiri dari beberapa baris tanaman sangat efektif mereduksi bising hingga $11.27 \%$, dengan nilai IL tertinggi mencapai $19.10 \mathrm{~dB}$. Pola semak berbentuk jalur sangat efektif mengurangi kebisingan apabila kedua sumber suara terletak pada level ketinggian yang tidak berbeda jauh atau dengan kata lain posisi sumber suara terletak pada level yang sama dengan posisi barrier. Sementara itu, untuk pola pohon berkelompok sangat efektif dalam mengurangi bising hingga $12.21 \%$, đengan nilai IL tertinggi mencapai $13.42 \mathrm{~dB}$. Pola pohon berkelompok sangat efektif mengurangi kebisingan apabila kedua sumber suara berada pada level Retinggian yang berbeda jauh atau dengan kata lain posisi sumber suara terletak pada level ketinggian yang berbeda dengan barrier.

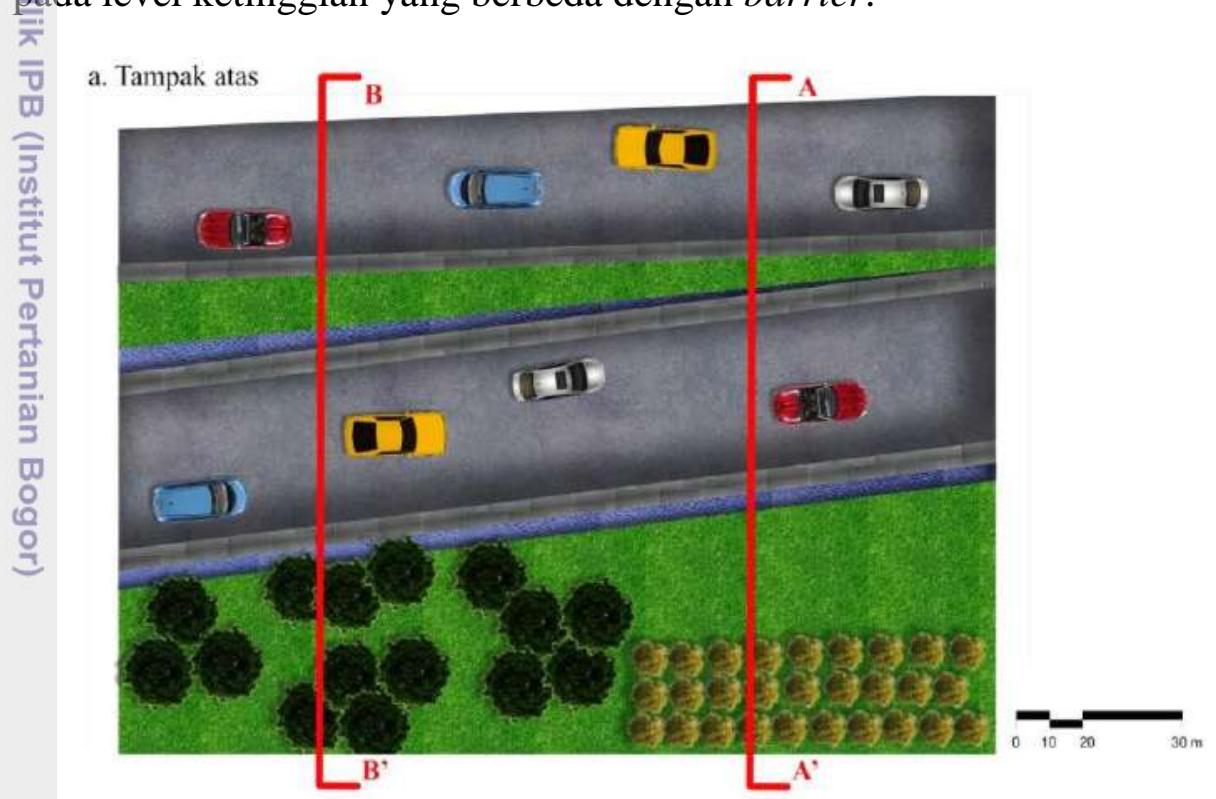

b. Tampak samping - potongan A-A'

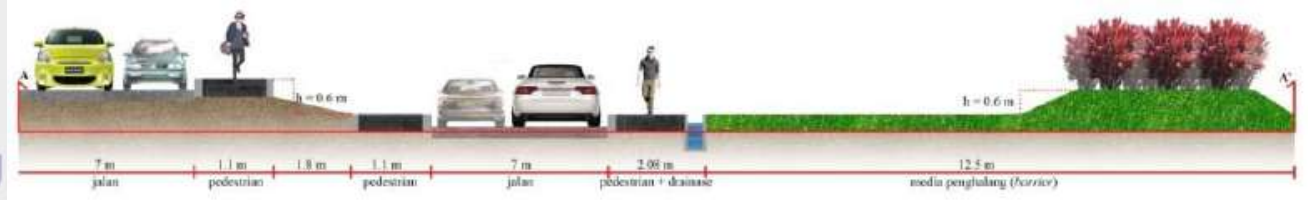

c. Tampak samping - potongan B-B'

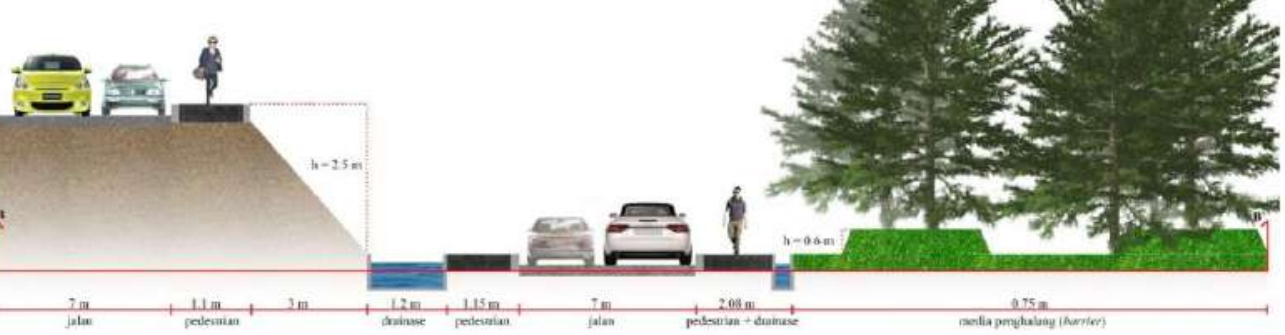

Gambar 53 Ilustrasi rekomendasi penataan barrier 


\section{SIMPULAN DAN SARAN}

\section{Simpulan}

Lingkungan perumahan sebaiknya dapat memberikan kenyamanan bagi penghuninya. Pada perumahan IPB 1 Baranangsiang, tingkat kebisingan rata-rata 16 jam $\left(\mathrm{L}_{\mathrm{s}}\right.$ ) pada hari kerja (Senin dan Rabu) lebih tinggi, yaitu 89.2 dB dan 87.5 $\mathrm{dB}$, dibandingkan hari libur (Minggu), yaitu $85 \mathrm{~dB}$. Dari ketiga pengulangan tersebut, tingkat kebisingan rata-rata di perumahan tersebut adalah 87.2 dB. Jarak berpengaruh terhadap nilai kebisingan, semakin dekat dengan sumber bising maka nilai kẹisingannya akan semakin besar, begitu juga sebaliknya apabila semakin jauh farak dengan sumber bising maka nilai kebisingannya akan semakin berkuraing. Gangguan kebisingan yang dirasakan oleh penduduk perumahan tersebu tut sebagian besar adalah gangguan psikologis, diantaranya mengganggu konse $\overline{\bar{\mu}}$ rasi, tidak nyaman, dan gangguan tidur. Penduduk yang paling banyak merasa $\bar{k}$ an gangguan kebisingan adalah penduduk yang tinggal dekat dengan sumber suara atau pada jarak $\leq 10 \mathrm{~m}$.

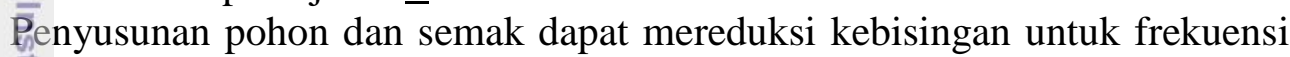
rendaledan tinggi. Pola penyusunan tanaman yang efektif mereduksi bising adalah pohon ${ }_{7}^{*}$ berkelompok dan beberapa baris semak berbentuk jalur. Dari hasil penelifian diatas, pola penyusunan pohon berkelompok efektif mereduksi bising hingga $13.42 \mathrm{~dB}$ atau $\pm 12.21 \%$, sedangkan pola penyusunan semak berbentuk jalur nampu mereduksi hingga $19.10 \mathrm{~dB}$ atau $\pm 11.27 \%$. Pohon damar (Agathis dammara Lamb.) efektif mengurangi bising pada frekuensi $5000 \mathrm{~Hz}-8000 \mathrm{~Hz}$, semako pucuk merah (Syzygium oleana Br.Ex) efektif mereduksi bising pada frekuensi $315 \mathrm{~Hz}-8000 \mathrm{~Hz}$, serta tanaman teh-tehan (Acalypha siamensis Oliv. ex Gage) mampu mereduksi bising pada frekuensi $200 \mathrm{~Hz}$ dan $250 \mathrm{~Hz}$.

Rekomendasi yang dapat diberikan untuk mengurangi kebisingan pada halaman rumah dapat menanam beberapa jenis tanaman dengan pola berkelompok dan menyebar. Pada penelitian ini, ditemukan bahwa halaman rumah yang memiliki pola penanaman berkelompok dan menyebar efektif dalam mereduksi bising pada kawasan perumahan. Selain itu, upaya pengendalian kebisingan pada area luar perumahan, yang dekat dengan sumber suara, dapat memasang kombinasi antara tanaman dan gundukan tanah. Rekomendasi penyusunan barrier tersebut dapat diterapkan pada lingkungan perumahan sehingga menciptakan kenyamanan audial bagi penduduk perumahan.

\section{Saran}

Berlu dilakukan penelitian lanjutan pada penelitian di lapang untuk mengetahui tingkat bising di dalam rumah (indoor) jika rumah tersebut dekat dengan sumber suara (jalan), sehingga dapat menyusun pola barrier yang tepat untuk-diterapkan pada lingkungan perumahan tersebut. Sementara itu, diperlukan juga penelitian simulasi laboratorium untuk mengetahui efektivitas jenis dinding penghalang agar dapat dijadikan barrier pada area dalam perumahan. 


\section{DAFTAR PUSTAKA}

Adrian A. 2015. Lingkungan rumah ideal. Prosiding Temu Ilmiah IPLBI. C057C062.

Anangga R, Nasution H, Iskandarini. 2015. Analisis pengaruh gangguan psikologis, komunikasi dan fisiologis terhadap kinerja karyawan di PT Aneka Gas Industri Medan. Jurnal Ilmiah Research Sains. 1(3): 1-15.

Angotti. 1993. Metropolis 2000. London (UK): Routhledge.

Bachtiar VS, Dewilda Y, Wemas B. 2013. Analisis tingkat kebisingan dan usaha I pengendalian pada unit produksi pada suatu industry di Kota Batam. Teknik Lingkungan. 10(2):85-93.

Balitbang] Badan Penelitian dan Pengembangan Departemen Pekerjaan Umum. ¿ 2005. Mitigasi Dampak Kebisingan Akibat Lalu Lintas Jalan. Jakarta (ID): 3. Departemen Pekerjaan Umum RI.

[B]PS] Badan Pusat Statistik Kota Bogor. 2018. Kota Bogor Dalam Angka 2018. T Bogor (ID): Badan Pusat Statistik Kota Bogor.

Bruel, Kjaer. 1988. Acoustic Noise Measurements. Denmark: K. Larsen \& Son A/S DK-2600 Glostrup.

Earpenter PL, Walker TD, Lanphear FO. 1975. Plants in The Landscape. San Fransisco (US): W.H. Freeman and Co.

Ghun-song H, Tkebuchava T. 2019. E-noise: An increasingly relevant health risk. Journal of Integrative Medicine, siap terbit.

Ë ए Nostrand Reinhold.

bahlan EN. 2004. Hutan Kota Untuk Pengelolaan dan Peningkatan Kualitas

$\cong$ Lingkungan Hidup. Bogor (ID): Institut Pertanian Bogor.

Djalante S. 2010. Analisis tingkat kebisingan di jalan raya yang menggunakan Alat Pemberi Isyarat Lalu Lintas (APIL). Jurnal Smartek. 8(4): 260-300.

Doelle LL. 1965. Acoustics in Architectural Design [bibliografi]. Ottawa (CA): National Research Council Canada.

Endi DR, Palupi M. 2011. Kajian metode sampling pengukuran kebisingan dari keputusan menteri lingkungan hidup no. 48 tahun 1996. Standarisasi. 13(3): $176-183$.

Fakuara Y. 1986. Hutan Kota, Peranan dan Permasalahannya. Bogor (ID): Manajemen Hutan Fakultas Kehutanan IPB.

Fanng CF, Ling DL. 2003. Investigation of the noise reduction provided by tree belts. Landscape Urban Planning. 63(2003): 187-195.

Fithri P, Annisa IQ. 2015. Analisis intensitas kebisingan lingkungan kerja pada area utilities unit PLTD dan boiler di PT Pertamina RU II Dumai. Sains, Teknologi dan Industri. 12(2):278-285.

(4lakim R. 2006. Rancangan Visual Lansekap Jalan Panduan Estetika Dinding ב.. Penghalang Kebisingan. Jakarta (ID): Bumi Aksara.

Herawati P. 2016. Dampak kebisingan dari aktifitas Bandara Sultan Thaha Jambi terhadap pemukiman sekitar bandara. Jurnal Ilmiah Universitas Batanghari Jambi. 16(1): 104-108. 
Hidayat IW. 2010. Kajian fungsi ekologi jalur hijau jalan sebagai penyangga lingkungan pada Tol Jagorawi. Jurnal Manusia dan Lingkungan. 17(2):124133.

Hong JY, Jeon JY. 2017. Exploring spatial relationships among soundscape variables in urban areas: a spatial statistical modeling approach. Landscape and Urban Planning. 157: 352-364.

Ikron, Djaja IM, Wulandari RA. 2007. Pengaruh kebisingan lalulintas jalan terhadap gangguan kesehatan psikologis anak SDN Cipinang Muara Kecamatan Jatinegara, Kota Jakarta Timur, Propinsi DKI Jakarta, 2005. Makara Kesehatan. 2(1): 32-37.

Irwan ZD. 1994. Peranan bentuk dan struktur hutan kota terhadap kualitas lingkungan kota: studi kasus lokasi pemukiman Kota Jakarta [disertasi]. Bogor (ID): Institut Pertanian Bogor.

Jiang E, Kang J. 2016. Combined acoustical and visual performance of noise barîjers in mitigating the environmental impact of motorways. Science of the Totäl Environment. 534(2016): 52-60. doi: 10.1016/j.scitotenv.2015.11.010.

Kalansuriya CM, Pannila AS, Sonnadara DUJ. 2009. Effect of roadside vegetation on the reduction of traffic noise levels. Proceedings of the Technical Sessions. 25: 1 - 6 .

Karyon̄o TS. 2005. Fungsi ruang hijau kota ditinjau dari aspek keindahan, kenyamanan, kesehatan, dan penghematan energi. Teknik Lingkungan. 6(3): 452-457.

King EA, Murphy E, Rice HJ. 2011. Evaluating the impact on noise levels of a ban 16(7): 532-539.

Kristiyanto F, Kurniawan B, Wahyuni I. 2014. Hubungan intensitas kebisingan dengan gangguan psikologis pekerja departemen laundry bagian washing PT X Semarang. Jurnal Kesehatan Masyarakat. 2(1): 75-79.

Kwanda T. 2000. Penerapan konsep perencanaan dan pola jalan dalam perencanaan real estate di Surabaya. Dimensi Teknik Arsitektur. 28(2): 106-113.

Lagonigro R, Martori JC, Apparicio P. 2018. Environmental noise inequity in the city of Barcelona. Transportation Research Part D. 63(2018):309-319. doi: 10.1016/j.trd.2018.06.007.

Lintong F. 2009. Gangguan pendengaran akibat bising. Biodemik. 1(2):81-86.

Maekawa Z, Rindel JH, Lord P. 2011. Environmental and Architectural Acoustics $2^{\text {nd }}$ edition. New York (US): Spon Press.

Manohar S, Dahar K, Adler HJ, Ding D, Salvi R. 2016. Noise-induced hearing loss: Neuropathic pain via Ntrk 1 signaling. Molecular and Cellular Neuroscience. 75: 101-112.

Marsh WM. 1986. Landscape Planning Environmental Applications. New York (US): John Wiley and Son Inc.

Mashuri. 2007. Penggunaan akustik luar ruangan dalam menanggulangi kebisingan pada bangunan. Jurnal SMARTek. 5(3): 196-206.

Merska O, Mieczkowski P, Zymelka D. 2016. Low-noise thin surface course evaluation of the effectiveness of noise reduction. 14: 2688-2697.

Murphy E, King EA. 2014. Environmental Noise Pollution - Noise Mapping, Public Health, and Policy. US: Elsevier. 
Onder S dan Kocbeker Z. 2012. Importance of the green belts to reduce noise pollution and determination of roadside noise reduction effectiveness of bushes in Konya, Turkey. Biological, Biomolecular, Agricultural, Food and Biotechnological Engineering. 6(6): 373-376.

Papadimitriou KD, Mazaris AD, Kaliimanis AS, Pantis JD. 2009. Cartographic representation of the sonic environment. Journal of Cartography. 46(2): 126135.

Peterson APG. 1980. Handbook of Noise Measurement $9^{\text {th }}$ ed. Massachusetts (US): GenRad

Pramono G. 2008. Akurasi metode IDW dan kriging untuk interpolasi sebaran I sedimen tersuspensi di Maros, Sulawesi Selatan. Forum Geografi. 22(1): 145158 .

BT Jasamarga. 2018. Laporan Tahunan 2018. PT Jasarmarga (Persero) Tbk.

Pudjowati UR, Yanuwiyadi B, Sulistiono R, Suyadi. 2013. Estimation of noise . reduction by different vegetation type as a noise barrier: a survey in highway $\overline{\bar{\lambda}}$ along Waru - Sidoarjo in East Java, Indonesia. Engineering And Science. तु 2(11): 20-25.

Republik Indonesia. 2011. Undang-Undang Perumahan dan Kawasan of Permukiman Nomor 1. Jakarta (ID): Sekretariat Negara.

Seong JC, Park TH, Ko JH, Chang SI, Kim M, Holt JB, Mehdi MR. 2011.

7 Modeling of road traffic noise and estimated human exposure in Fulton County, 7. Georgia, USA. Environment International. 37: 1336-1341.

Setiawan MF. 2010. Tingkat kebisingan pada perumahan di perkotaan. Teknik Sipil dan Perencanaan. 2(2): 191-200.

Spon FN. 1991. Noise Control in Industry. London, New York, Tokyo, Melbourne, Madras: An Imprint of Chapman and Hill.

Sugiyono. 2011. Statistika Untuk Penelitian. Bandung (ID): Alfabeta.

Suharjanto G. 2012. Fenomena perbedaan tingkat kebisingan pada 2 unit ruang tidur: studi kasus rumah tinggal peneliti di tepi jalan raya. ComTech. 3(2): 944951.

Suryadi Y, H Surjono, Sutjahjo, Sanim B, Rustiadi E, Soma S. 2008. Kajian Pengendalian Pemanfaatan Ruang Menuju Pembangunan Kota Bogor. Forum Pascasarjana. 31(4): 229.

Taherzadeh S. 2014. Noise Control. West Sussex (UK): John Willey \& Sons Ltd.

Tiesler C, Birk M, Thiering E. 2013. Exposure to road traffic noise and children's behavioural problems and sleep disturbance: Results from the GINIplus and

WISAplus studies. Environmental Research. 123: 1-8.

Pilaar S, Rogi OHA, Tinagon AJ. 2012. Kajian tipomorfologi kawasan permukiman terencana di Kota Manado. Media Matrasain. 9(3): 1-21.

The Vehicles Technologies Office. 2012. Vehicles per Thousand People: US

$\rightarrow$ Compared to Other Countries. US: US Department of Energy.

৫iohjiwa AD, Soetomo S, Sjahbana JA, Purwanto E. 2010. Kota Bogor dalam

ㄱ. Tarik Menarik Kekuatan Lokal dan Regional. Seminar Nasional Riset Arsitektur dan Perencanaan. Yogyakarta (ID): Universitas Gadjah Mada.

Triyuly W, Amalia F. 2014. Identifikasi pola perumahan rumah sangan sederhana di Kawasan Sematang Borang Kota Palembang. Prosiding Temu Ilmiah IPLBI. 39-44. 
Umiati S. 2012. Pengaruh pagar tembok terhadap tingkat kebisingan pada perumahan jalan Ratulangi Makassar. Jurnal Rekayasa Sipil. 8(1): 21-28.

Van Retherghem T, Forssén J, Attenborough K, Jean P, Defrance J, Hornikx M, Kang J. 2015. Using natural means to reduce surface transport noise during propagation outdoors. Applied Acoustics. 92: 86-101.

Walgito B. 1981. Pengantar Psikologi Umum. Yogyakarta (ID): ANDI.

Wang H, Luo P, Cai M. 2018. Calculation of noise barrier insertion loss based on varied vehicle frequencies. Applied Science. 8(100):1-13.

Widagdo S. 1998. Studi tentang reduksi kebisingan menggunakan vegetasi dan kualitas visual lanskap jalan Tol Jagorawi [tesis]. Bogor (ID): Institut Pertanian Boḡor.

Wilson̄ CE. 1994. Noise Control (Measurement, Analysis, and Control of Sound and fVibration). Florida (US): New Jersey Institute of Technology.

White RG, Walker JG. 1982. Noise and Vibration. Michigan (US): Ellis Horwood. World Health Organization (WHO). 1999. Guidelines for Community Noise. Genev va (CH): World Health Organization.

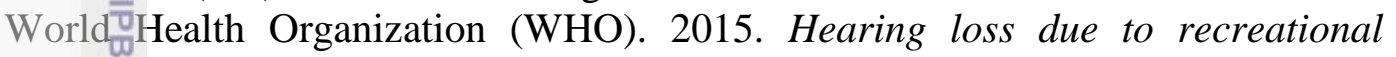
exposure to loud sounds. Geneva $(\mathrm{CH})$ : World Health Organization.

Workpiace Health and Safety (WHS). 2015. Code of Practice for Noise

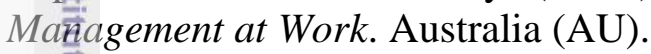

Yulianto AR. 2013. Faktor-faktor yang berhubungan dengan gangguan nonauditory akibat kebisingan pada musisi rock. Jurnal Kesehatan Masyarakat. 2(1) $1-11$.

Zaki $\mathcal{A}$, Wuryandari T, Suparti. 2014. Analisis varian percobaan factorial dua factër rakl dengan metode fixed additive main effects and multiplicative integraction. Journal Gaussian. 3(4): 529-536. 
LAMPIRAN

Lampiran 1 Tingkat kebisingan setiap titik pengukuran

Hari: Minggu, 31 Maret 2019

\begin{tabular}{|c|c|c|c|c|}
\hline \multirow{2}{*}{ Titik } & \multicolumn{4}{|c|}{ Waktu (WIB) / Tingkat bising (dB) } \\
\hline & $06.00-09.00$ & $09.00-14.00$ & $14.00-17.00$ & $17.00-22.00$ \\
\hline 1 & 78.16 & 69.04 & 70.48 & 74.03 \\
\hline 2 & 70.41 & 75.12 & 72.06 & 76.32 \\
\hline ()) 3 & 69.45 & 72.92 & 72.25 & 71.77 \\
\hline I 4 & 70.81 & 71.11 & 70.51 & 72.05 \\
\hline$\frac{\mathbb{W}}{\lambda} 5$ & 69.75 & 71.59 & 73.96 & 72.66 \\
\hline$\frac{n}{y} 6$ & 52.80 & 56.36 & 55.45 & 58.74 \\
\hline 7 & 49.04 & 61.93 & 57.85 & 60.55 \\
\hline 8 & 49.23 & 60.05 & 54.24 & 52.71 \\
\hline$\overline{\bar{\lambda}} 9$ & 72.05 & 70.94 & 72.57 & 73.23 \\
\hline$\overline{\bar{\nu}} 10$ & 50.19 & 54.21 & 57.64 & 69.71 \\
\hline$\stackrel{1}{=} 11$ & 49.80 & 56.31 & 51.93 & 52.64 \\
\hline 12 & 53.31 & 56.07 & 60.21 & 63.64 \\
\hline E 13 & 68.22 & 69.19 & 76.96 & 78.44 \\
\hline$\vec{\nabla} 14$ & 49.34 & 59.85 & 60.07 & 56.01 \\
\hline$\frac{1}{7} 15$ & 51.75 & 54.17 & 61.78 & 56.39 \\
\hline 16 & 55.94 & 53.98 & 57.04 & 59.39 \\
\hline 17 & 71.09 & 72.95 & 72.85 & 70.41 \\
\hline 18 & 53.15 & 49.39 & 67.94 & 57.67 \\
\hline 19 & 60.65 & 49.97 & 55.39 & 66.13 \\
\hline$\approx 20$ & 49.09 & 58.30 & 46.84 & 53.41 \\
\hline 21 & 76.30 & 70.32 & 71.48 & 72.39 \\
\hline 22 & 64.53 & 69.68 & 67.12 & 69.12 \\
\hline 23 & 63.64 & 62.63 & 58.79 & 58.78 \\
\hline 24 & 65.37 & 62.71 & 56.28 & 62.32 \\
\hline 25 & 70.45 & 70.09 & 68.13 & 75.02 \\
\hline 26 & 53.41 & 57.10 & 59.00 & 67.24 \\
\hline 27 & 55.50 & 60.00 & 67.22 & 61.45 \\
\hline
\end{tabular}

Hari: Senin, 1 April 2019

\begin{tabular}{|c|c|c|c|c|}
\hline \multirow{2}{*}{ Titik } & \multicolumn{4}{|c|}{ Waktu (WIB) / Tingkat bising (dB) } \\
\hline & 06.00-09.00 & $09.00-14.00$ & $14.00-17.00$ & $17.00-22.00$ \\
\hline 1 & 69.94 & 69.54 & 69.58 & 74.57 \\
\hline 2 & 71.81 & 74.79 & 75.48 & 73.91 \\
\hline$>3$ & 71.96 & 68.35 & 71.29 & 75.62 \\
\hline 4 & 71.61 & 79.09 & 71.24 & 76.56 \\
\hline 5 & 71.47 & 84.48 & 73.11 & 75.55 \\
\hline 6 & 60.32 & 68.03 & 67.06 & 59.85 \\
\hline $\bar{\Xi} 7$ & 57.46 & 57.34 & 60.30 & 56.64 \\
\hline$=8$ & 51.57 & 67.24 & 62.62 & 56.99 \\
\hline (3) 9 & 71.77 & 69.34 & 74.39 & 80.94 \\
\hline
\end{tabular}


Hari: Senin, 1 April 2019 (lanjutan)

\begin{tabular}{|c|c|c|c|c|c|}
\hline \multirow{2}{*}{\multicolumn{2}{|c|}{ 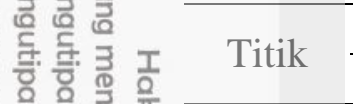 }} & \multicolumn{4}{|c|}{ Waktu (WIB) / Tingkat bising (dB) } \\
\hline & & 06.00-09.00 & $09.00-14.00$ & $14.00-17.00$ & $17.00-22.00$ \\
\hline & 10 & 63.06 & 73.11 & 84.08 & 55.68 \\
\hline & 11 & 51.24 & 61.72 & 60.21 & 56.56 \\
\hline & 12 & 55.16 & 62.11 & 67.42 & 51.67 \\
\hline & 13 & 69.69 & 72.34 & 72.46 & 71.43 \\
\hline & 14 & 53.55 & 59.82 & 69.67 & 58.37 \\
\hline & 15 & 49.44 & 55.92 & 59.95 & 50.10 \\
\hline & $16(0)$ & 48.18 & 57.54 & 59.30 & 51.99 \\
\hline & 17 工 & 69.82 & 68.71 & 72.61 & 72.31 \\
\hline & $18 \stackrel{\frac{\omega}{\lambda}}{0}$ & 59.99 & 56.20 & 73.28 & 53.91 \\
\hline 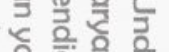 & $19 \stackrel{\frac{2}{0}}{\frac{0}{0}}$ & 50.88 & 50.08 & 57.52 & 56.27 \\
\hline & 20 & 42.31 & 52.39 & 69.27 & 50.91 \\
\hline & $21 \stackrel{3}{=}$ & 71.07 & 70.39 & 67.44 & 74.90 \\
\hline & 22 言 & 62.83 & 69.91 & 73.41 & 69.93 \\
\hline $\bar{F}$ & $23 \overline{0}$ & 52.93 & 64.55 & 63.89 & 56.86 \\
\hline$\overline{0}$ & $24 \stackrel{5}{\bar{z}}$ & 44.73 & 54.37 & 63.40 & 59.54 \\
\hline & $25 \stackrel{\text { 峁 }}{=}$ & 70.21 & 77.79 & 71.23 & 72.74 \\
\hline & $26 \overrightarrow{\vec{E}}$ & 60.25 & 56.83 & 64.49 & 66.55 \\
\hline & 27 & 55.40 & 64.01 & 70.55 & 78.32 \\
\hline$\cong$ & \multicolumn{5}{|c|}{ Hari: Rabu, 3 April 2019} \\
\hline & \multirow{2}{*}{$\operatorname{Titik}_{\tilde{\sigma}}^{\stackrel{0}{J}}$} & \multicolumn{4}{|c|}{ Waktu (WIB) / Tingkat bising (dB) } \\
\hline & & $06.00-09.00$ & $09.00-14.00$ & $14.00-17.00$ & $17.00-22.00$ \\
\hline ᄃ & $1 \%$ & 70.04 & 74.58 & 79.48 & 77.04 \\
\hline & $2 \beth$ & 82.84 & 77.71 & 75.79 & 76.85 \\
\hline & 3 & 83.55 & 76.43 & 77.20 & 75.43 \\
\hline & 4 & 76.41 & 76.46 & 76.49 & 74.23 \\
\hline 8 & 5 & 69.18 & 77.00 & 76.99 & 76.76 \\
\hline$\$$ & 6 & 52.41 & 51.44 & 59.04 & 62.95 \\
\hline ర్ల & 7 & 47.32 & 48.35 & 52.39 & 50.38 \\
\hline & 8 & 54.94 & 61.44 & 56.19 & 55.57 \\
\hline$\equiv$ & 9 & 66.29 & 75.79 & 76.43 & 78.39 \\
\hline ㄱ. & 10 & 64.67 & 53.50 & 56.71 & 54.06 \\
\hline$\dot{+}$ & 11 & 50.12 & 47.69 & 48.80 & 66.09 \\
\hline 0 & $12 \infty$ & 62.89 & 57.58 & 52.63 & 61.30 \\
\hline & 130 & 83.36 & 72.71 & 73.30 & 76.68 \\
\hline & 140 & 53.26 & 55.09 & 60.08 & 54.44 \\
\hline$\exists$ & $15^{-}$ & 53.96 & 50.24 & 52.47 & 51.58 \\
\hline$\sqrt{7}$ & $16>$ & 53.13 & 42.39 & 51.26 & 53.10 \\
\hline & 17 음 & 74.95 & 77.11 & 77.64 & 75.91 \\
\hline 음 & $18 \frac{2}{0}$. & 55.81 & 56.50 & 55.12 & 57.37 \\
\hline & $19 \subseteq$ & 47.38 & 50.56 & 50.30 & 51.33 \\
\hline & $20 \bar{\Xi}$ & 45.22 & 45.70 & 52.21 & 69.72 \\
\hline & $21 \subseteq$ & 76.15 & 74.85 & 76.07 & 70.96 \\
\hline & 220 & 62.76 & 64.69 & 68.40 & 67.69 \\
\hline
\end{tabular}


Hari: Rabu, 3 April 2019 (lanjutan)

\begin{tabular}{ccccc}
\multirow{2}{*}{ Titik } & \multicolumn{4}{c}{ Waktu (WIB) / Tingkat bising (dB) } \\
\cline { 2 - 5 } & $06.00-09.00$ & $09.00-14.00$ & $14.00-17.00$ & $17.00-22.00$ \\
\hline 23 & 60.40 & 60.60 & 58.46 & 57.27 \\
24 & 55.77 & 55.66 & 61.71 & 61.67 \\
25 & 76.95 & 72.41 & 70.31 & 74.34 \\
26 & 67.09 & 59.07 & 62.50 & 58.76 \\
27 & 60.91 & 54.13 & 55.77 & 55.49 \\
\hline
\end{tabular}

Lampiran 2 Karakteristik responden Perumahan IPB 1 Baranangsiang Jenis kelamin

\begin{tabular}{|c|c|c|c|}
\hline $\bar{\pi}$ & Jenis kelamin & Jumlah & Persentase $(\%)$ \\
\hline 힘 & Laki-laki & 10 & 3.3 \\
\hline$\frac{9}{3}$ & Perempuan & 20 & 66.7 \\
\hline \multicolumn{4}{|c|}{ Uू } \\
\hline ए & Usia & Jumlah & Persentase $(\%)$ \\
\hline$\overline{\bar{J}}$ & $<21$ tahun & 1 & 3.3 \\
\hline$\stackrel{n}{=}$ & $21-30$ tahun & 3 & 10 \\
\hline$\underset{\equiv}{\mathrm{E}}$ & $31-40$ tahun & 5 & 16.7 \\
\hline Ð & $41-50$ tahun & 12 & 40 \\
\hline$\frac{7}{31}$ & $>50$ tahun & 9 & 30 \\
\hline \multicolumn{4}{|c|}{ Pendidikan } \\
\hline$\circ$ & Pendidikan & Jumlah & Persentase $(\%)$ \\
\hline 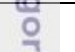 & SD & 3 & 10 \\
\hline & SMP & 2 & 6.7 \\
\hline & SMA/K & 6 & 20 \\
\hline & Diploma & 4 & 13.3 \\
\hline & Sarjana & 15 & 50 \\
\hline \multicolumn{4}{|c|}{ Pekerjaan } \\
\hline & Pekerjaan & Jumlah & Persentase $(\%)$ \\
\hline & Pegawai negeri & 2 & 6.67 \\
\hline & Pegawai swasta & 10 & 33.3 \\
\hline & Ibu rumah tangga & 10 & 33.3 \\
\hline 0 & Lainnya & 8 & 26.7 \\
\hline \multicolumn{4}{|c|}{ Dama tinggal } \\
\hline 7 & Lama tinggal & Jumlah & Persentase $(\%)$ \\
\hline 6 & $<1$ tahun & 2 & 6.7 \\
\hline 그. & $1-3$ tahun & 4 & 13.3 \\
\hline$\Omega$ & $3-5$ tahun & 1 & 3.3 \\
\hline$\subseteq$ & $6-10$ tahun & 2 & 6.7 \\
\hline E & $>10$ tahun & 21 & 70 \\
\hline
\end{tabular}




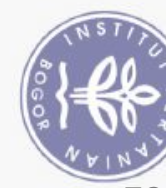

Jenis rumah

\begin{tabular}{ccc}
\hline Jenis rumah & Jumlah & Persentase (\%) \\
\hline 1 tingkat & 15 & 50 \\
2 tingkat & 15 & 50 \\
\hline
\end{tabular}

Keberadaan pohon di halaman rumah

\begin{tabular}{ccc}
\hline Keberadaan pohon & Jumlah & Persentase (\%) \\
\hline Tidak ada & 3 & 10 \\
Hanya $1-2$ pohon & 18 & 60 \\
Beberapa pohon & 9 & 30 \\
\hline Jarak & & \\
\hline Jumah dari sumber bising & & Persentase (\%) \\
\hline Jarak & Jumlah & 43.3 \\
$0-10 \mathrm{~m}$ & 13 & 33.3 \\
$21-30 \mathrm{~m}$ & 10 & 23.3 \\
\hline
\end{tabular}

Lampi⿶an 3 Propagasi suara merk speaker Speakêr merk soundplus egg (tampak samping)

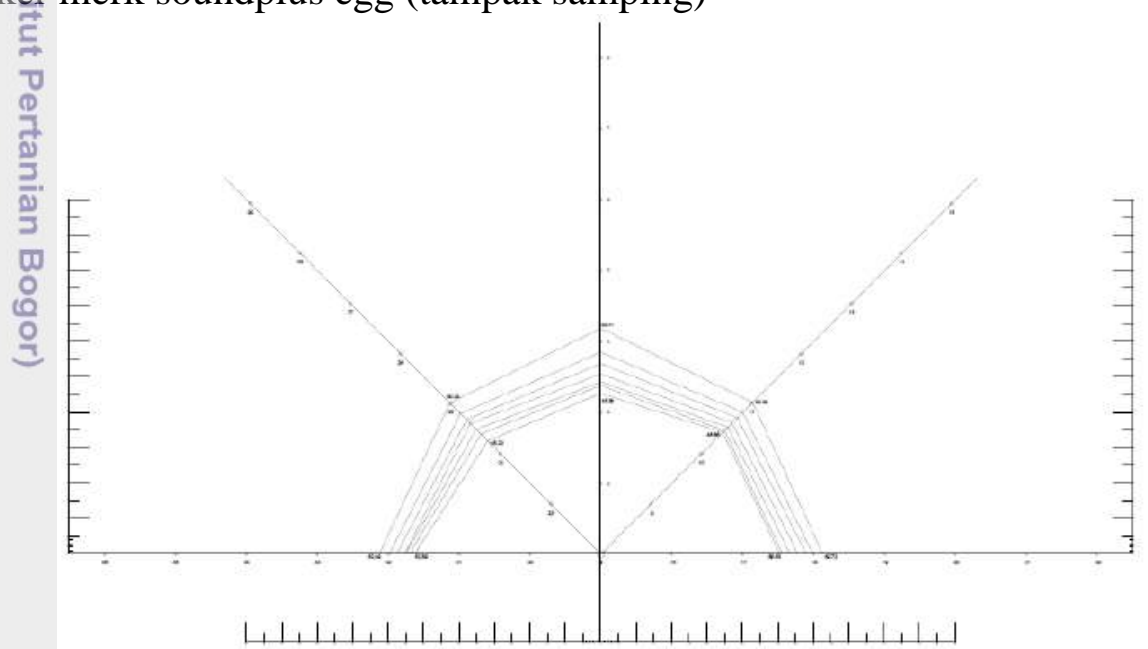

Speaker merk soundplus egg (tampak depan)

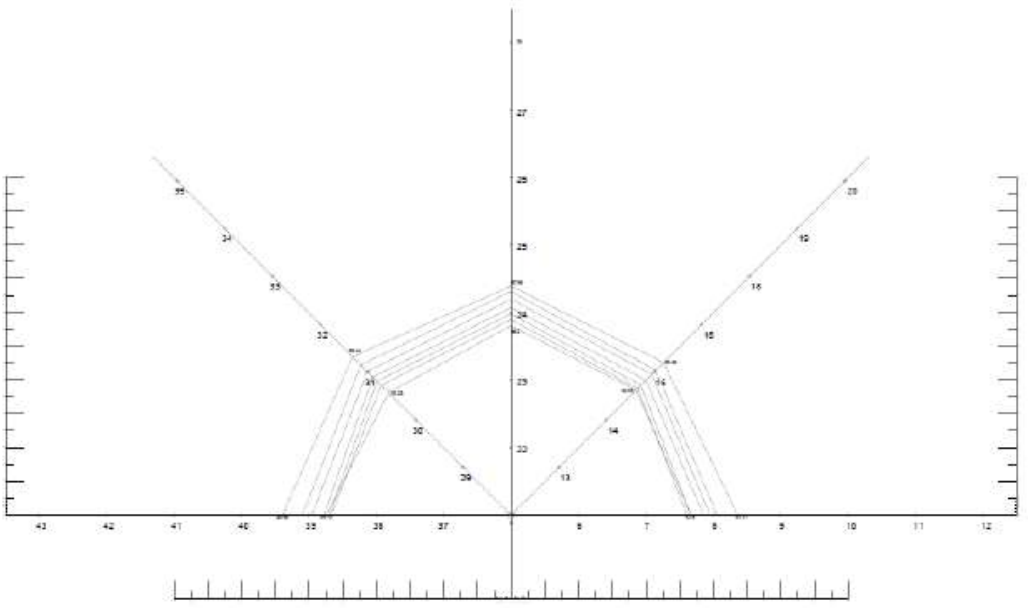


ทำ

을

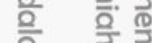

竞

올 总

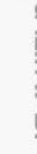

商
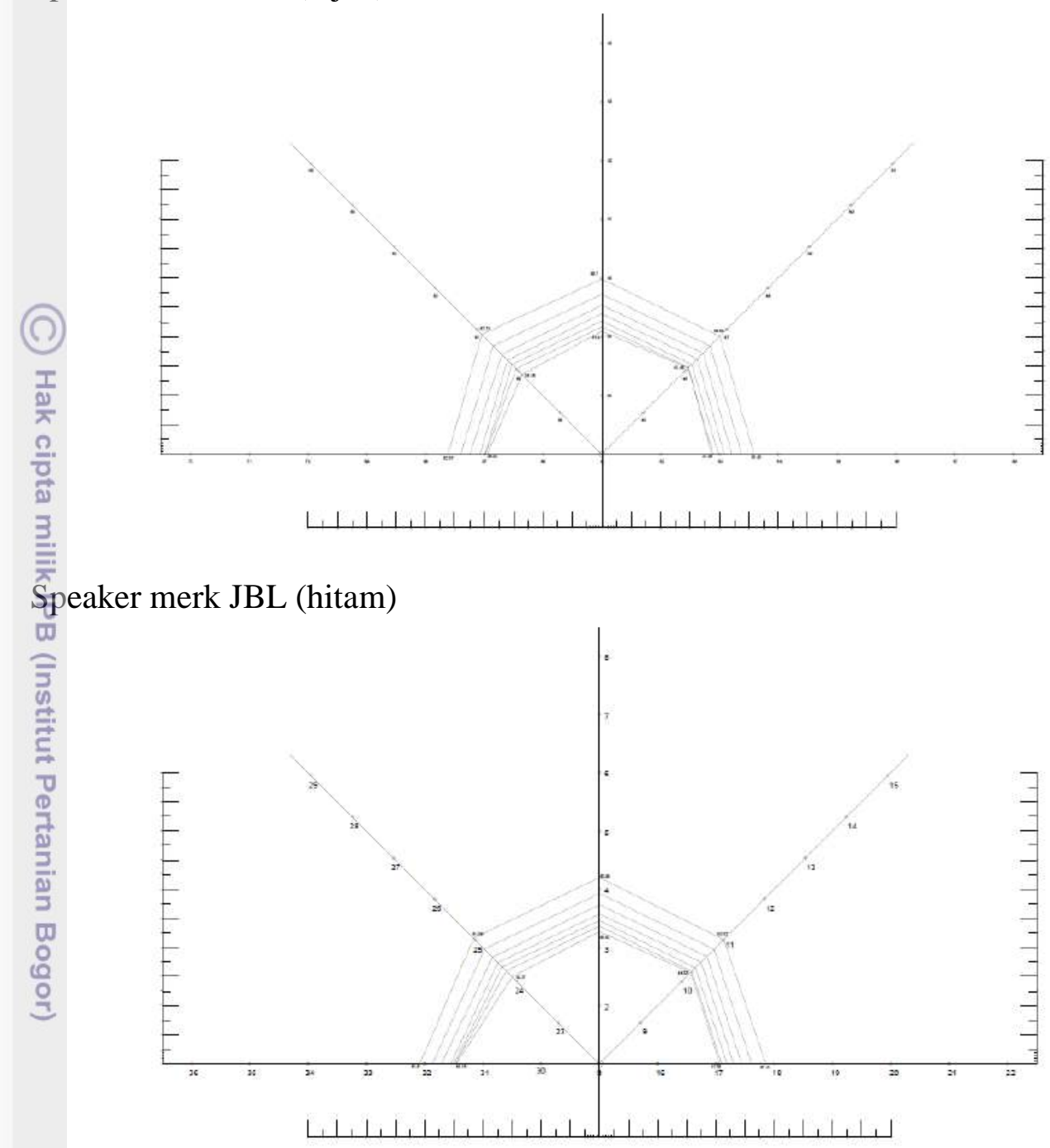


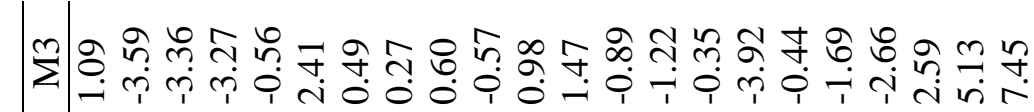
ลิ

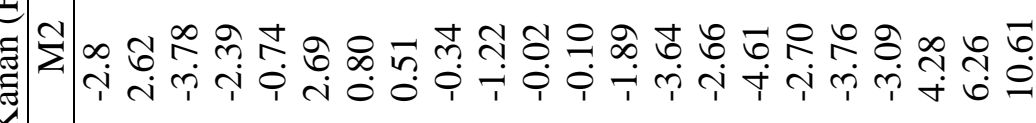
$\triangle$

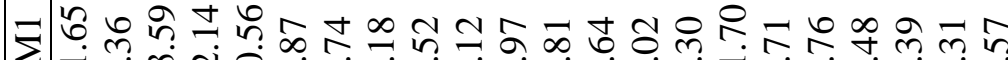

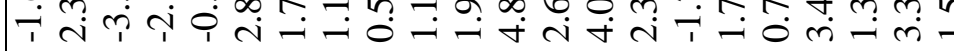

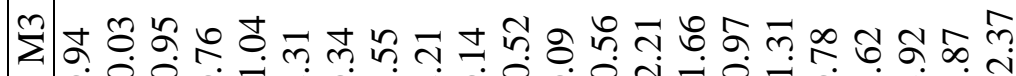
तิ

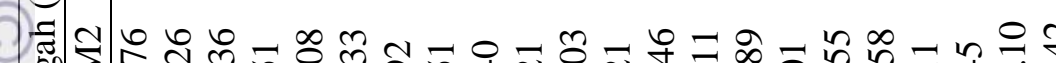

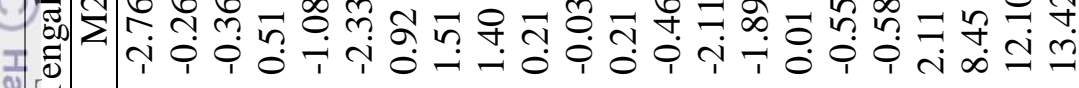

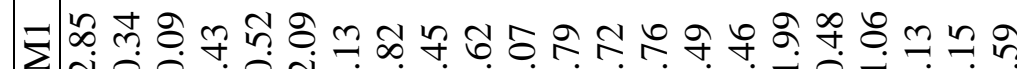

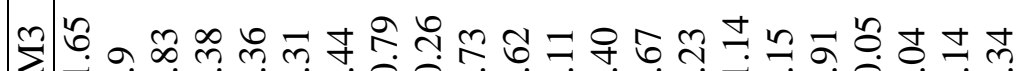

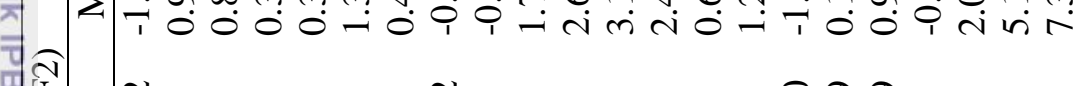

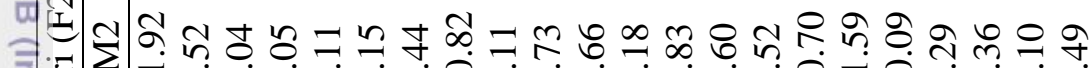

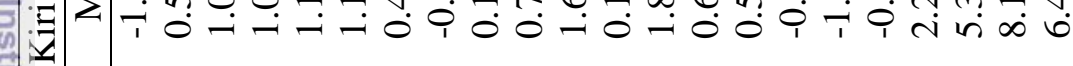

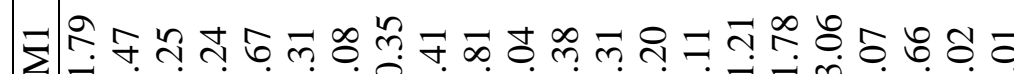

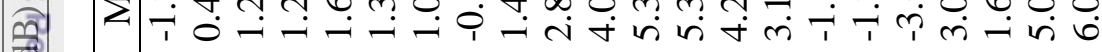

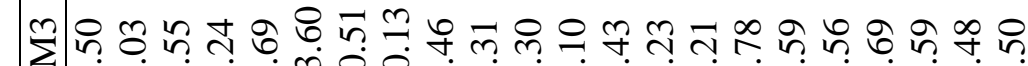
国

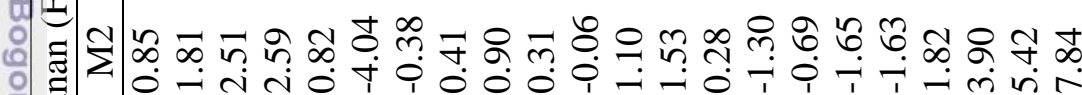
-

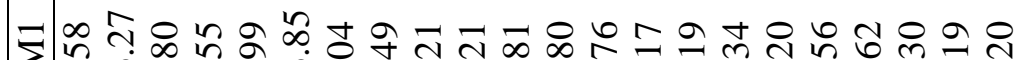

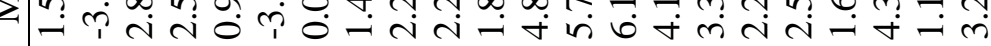

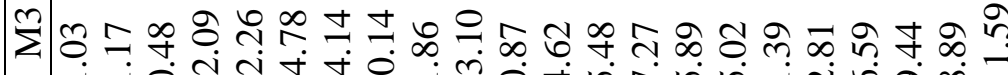
跤

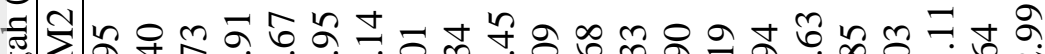

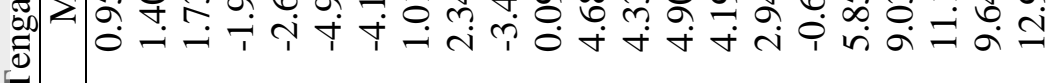

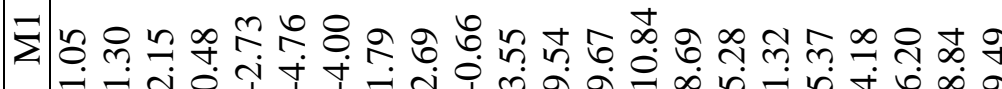

m

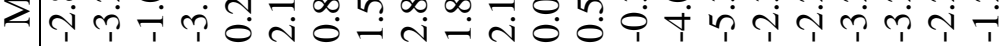

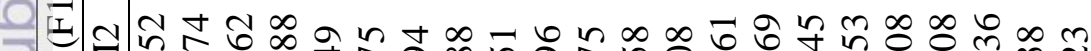

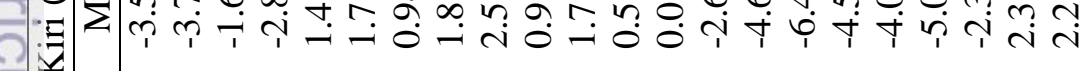

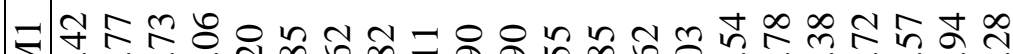

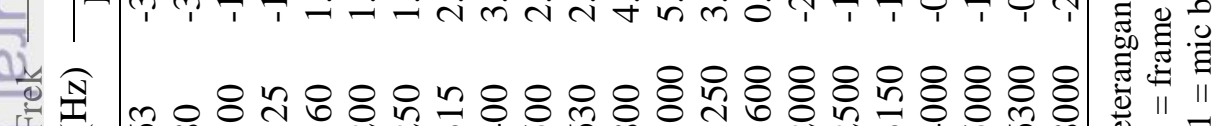




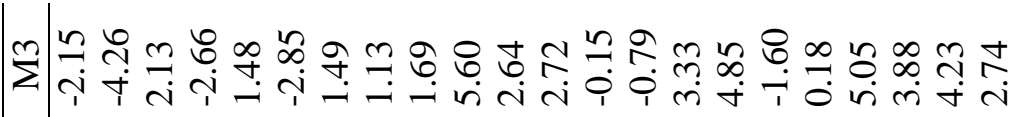

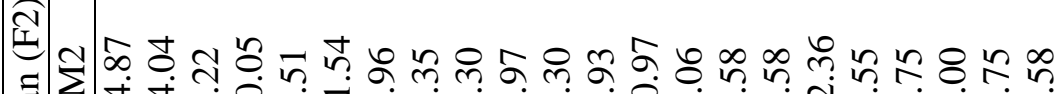
चाँ में 它

$\sum \&$ กิ

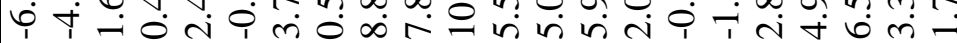

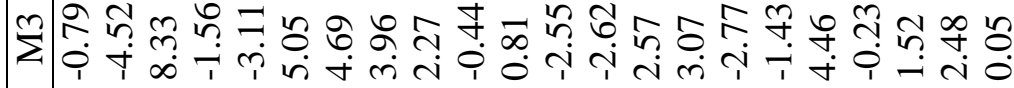
ฮิ

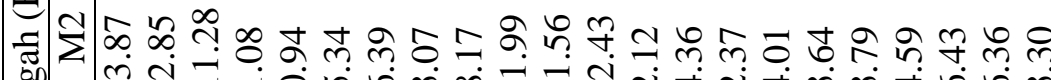
पi $\oplus$

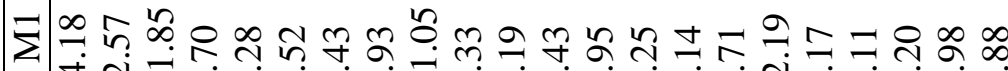
पि

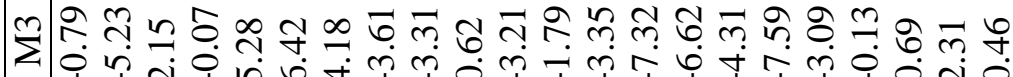
ง

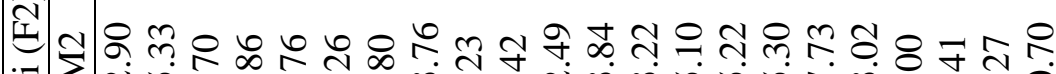

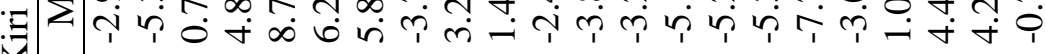

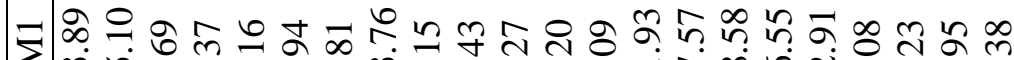

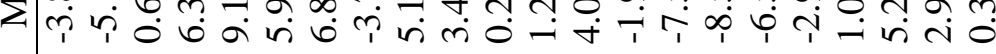

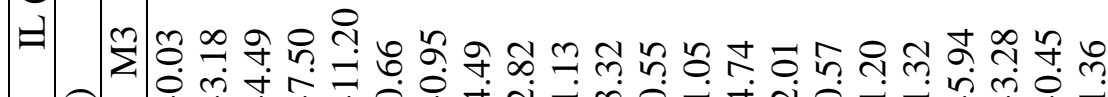
卧 สำ

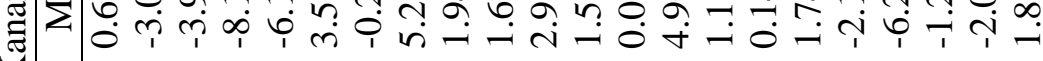
$\checkmark$

इ ल त

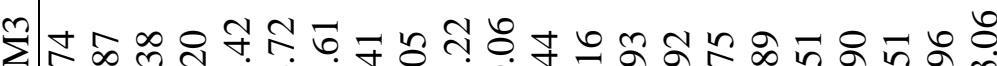
( $\widehat{\underline{\mathrm{E}}}$

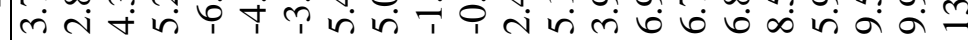

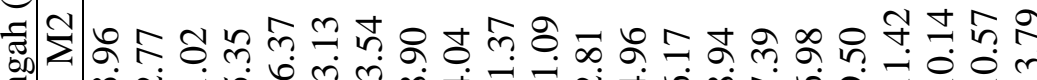
ङ

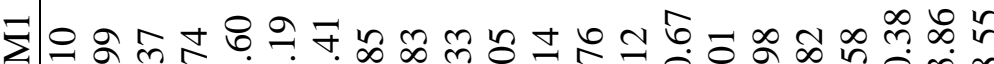

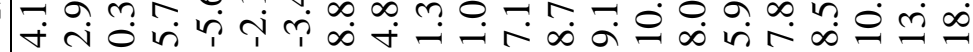

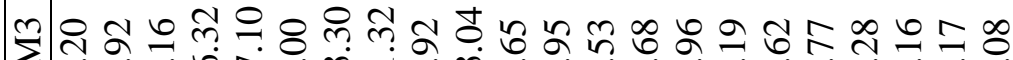

nं I \&

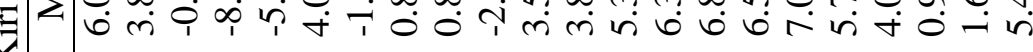

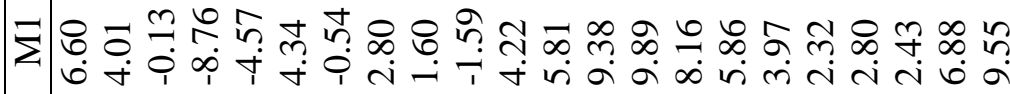
总预 


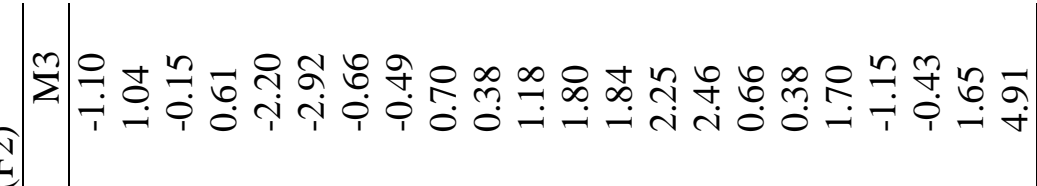

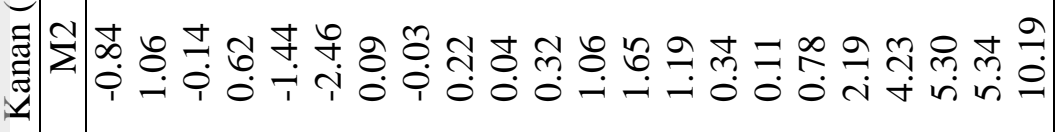

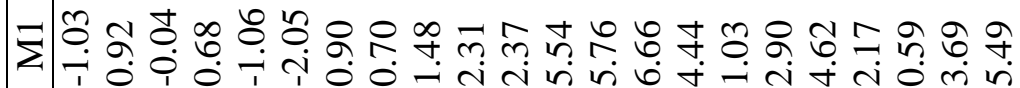

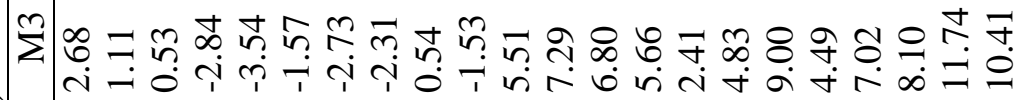
ชิ 9: 시 지

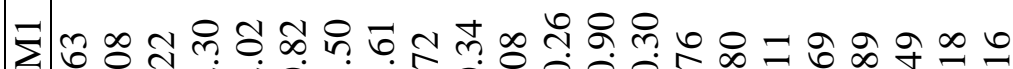

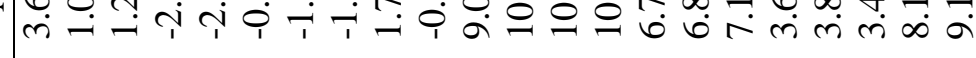

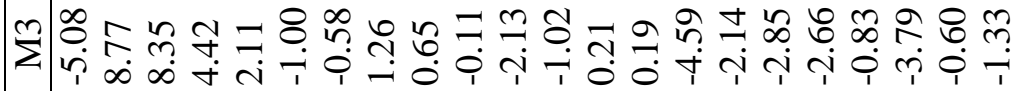
또

䛌

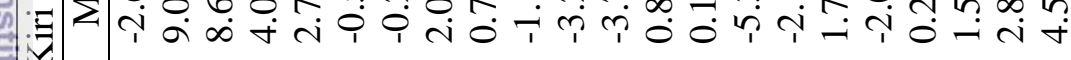

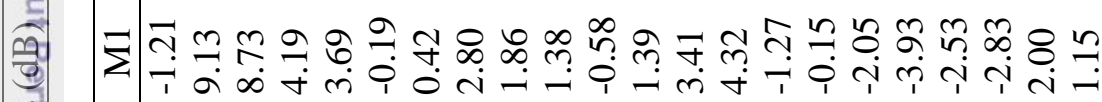

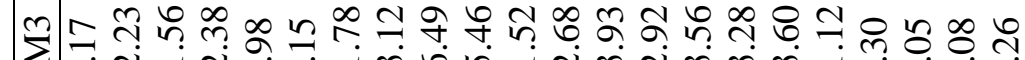
이리

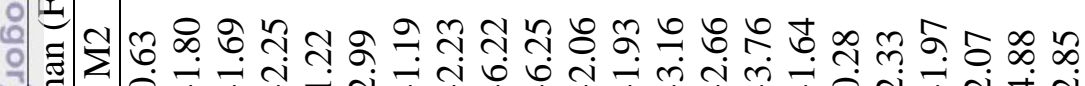
$\overline{2}$

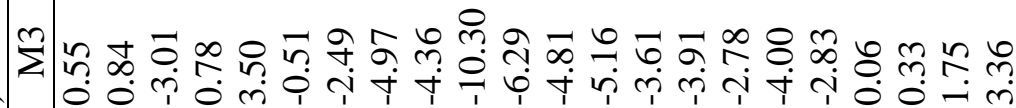

和

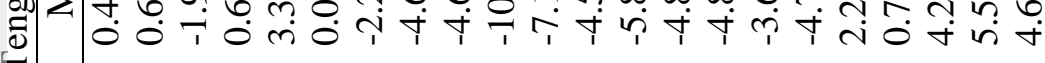

इ 东

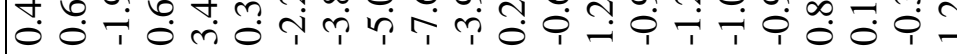

m

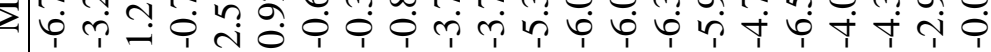

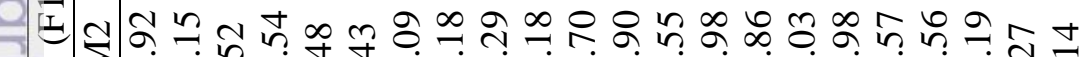

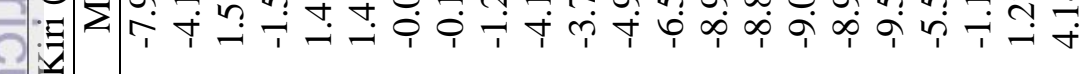
₹

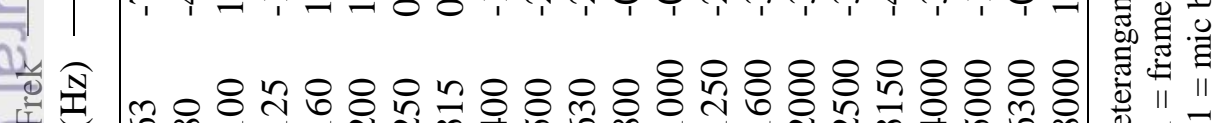




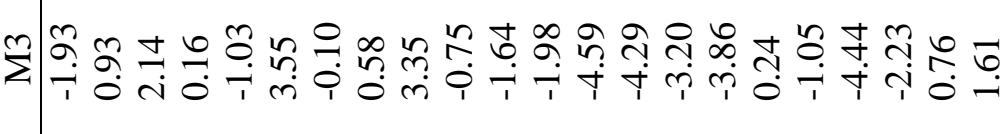
ลิ ㄱำ

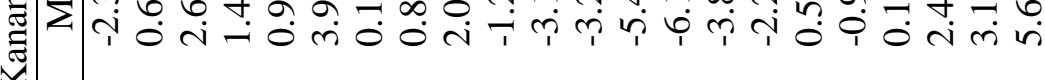

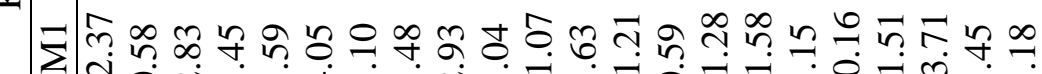
$\Sigma$ i

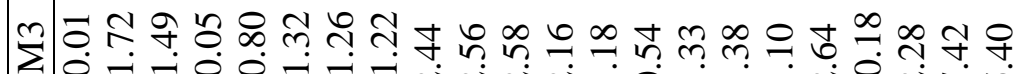
สิ

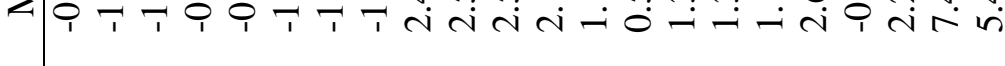

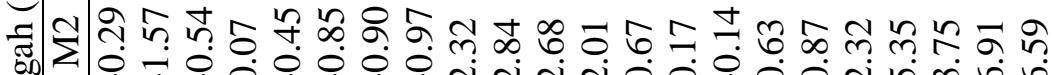
D)

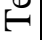

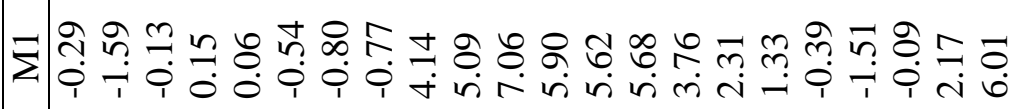

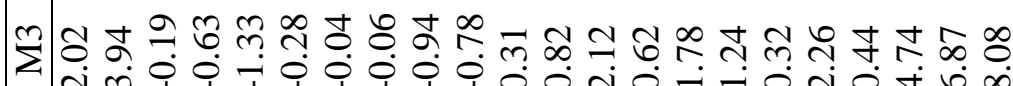
ชิ

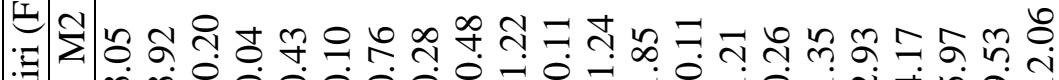

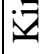

气्ञ

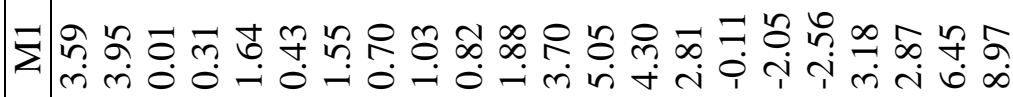

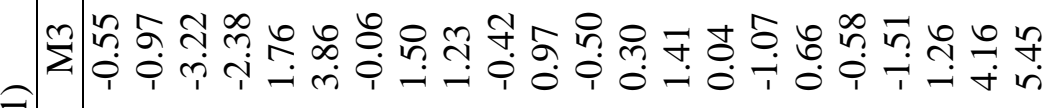
岳 ㄱํำ สำ \&

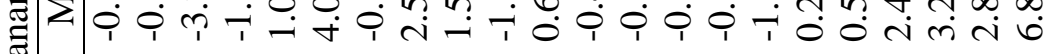

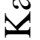

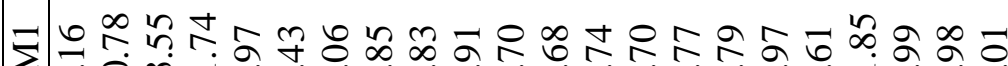
इ

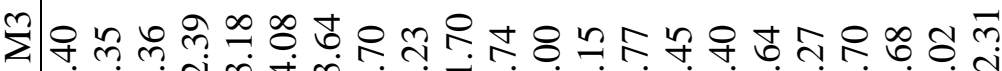
$\overparen{\overrightarrow{1}}$

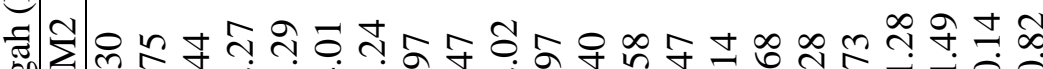

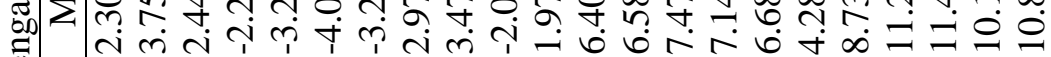
(1)

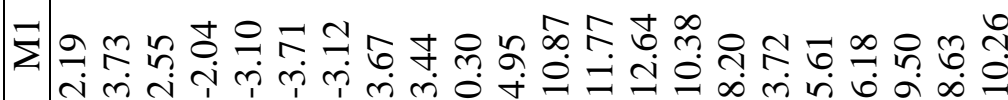

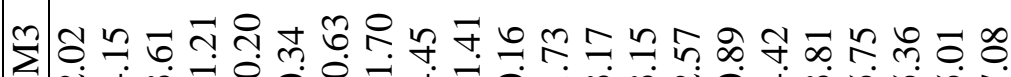
(ิ)

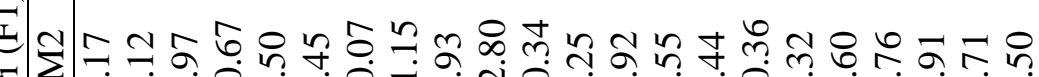
$\because$

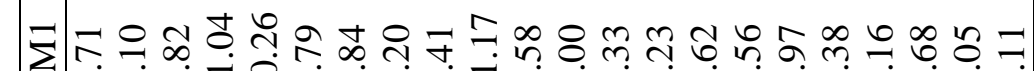

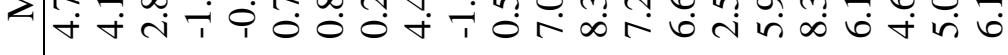
范全 


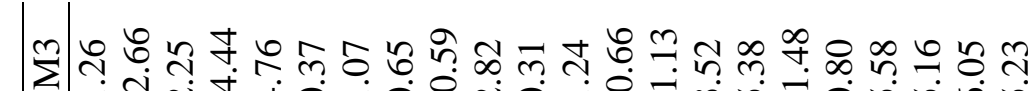
ลิ สี 華

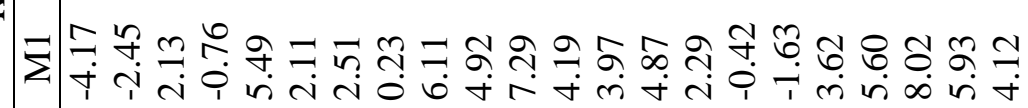
$\sum$ 产 论

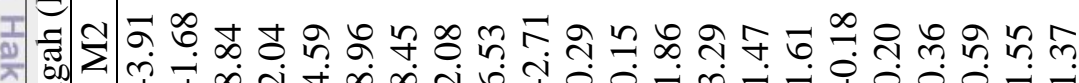
의 를

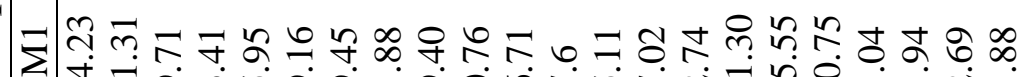

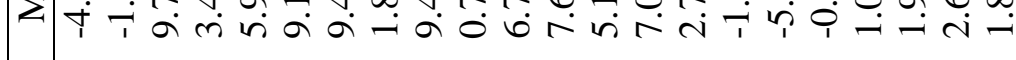

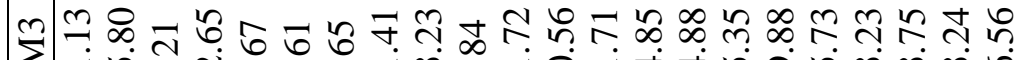
ชิ

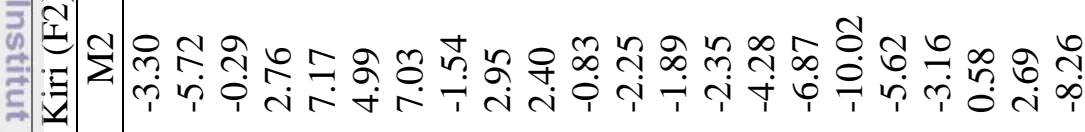

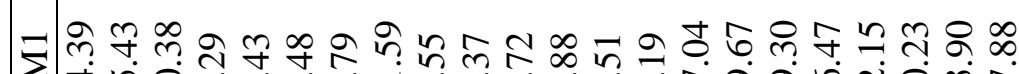

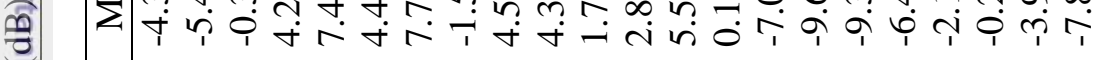

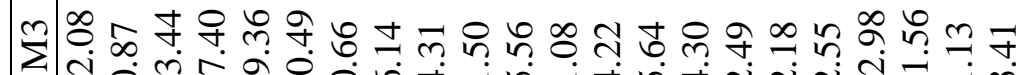

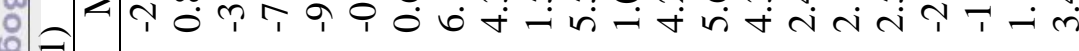

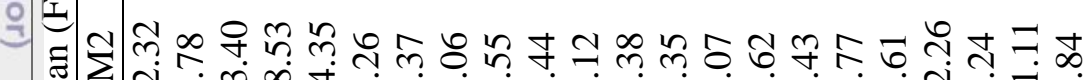

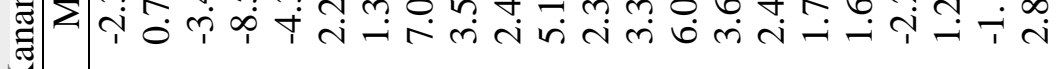
$\checkmark$

$\bar{\Sigma}=0$ 우

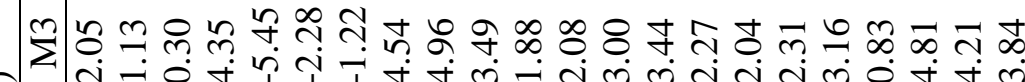

इฟ in

mํํ m

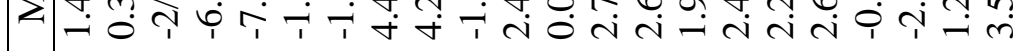

₹゙ $\stackrel{\infty}{-0}$ i

इ त तै 
œ สิ 폰 ป $\check{\simeq}$

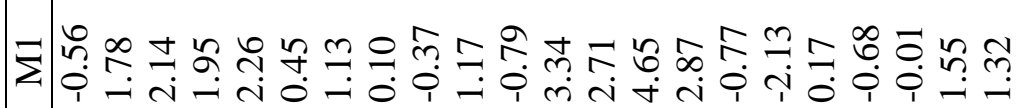

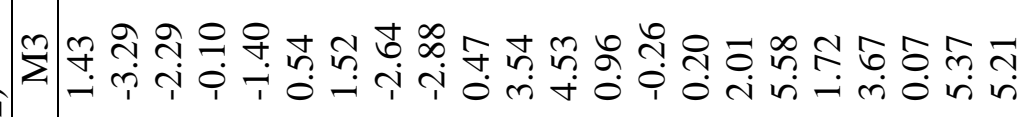
穵

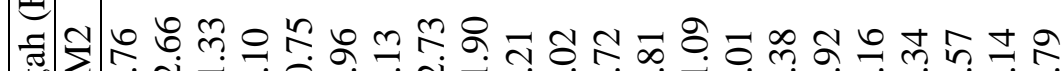
荡 $\sum$ i $\stackrel{0}{-1}$

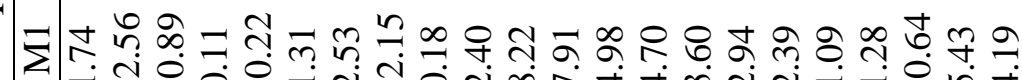

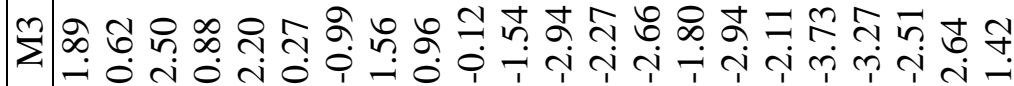
$\widehat{\widehat{ก}}$

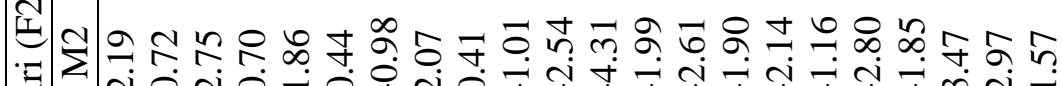
I

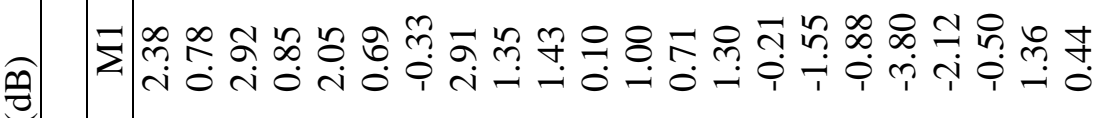

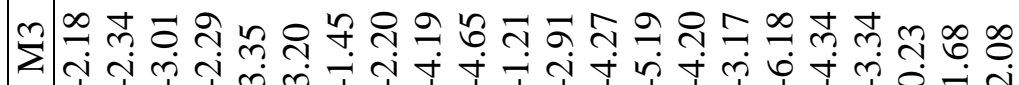

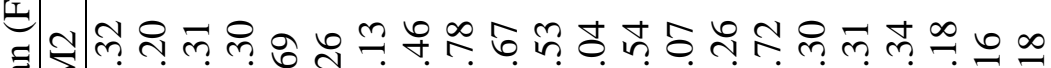
चี

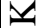

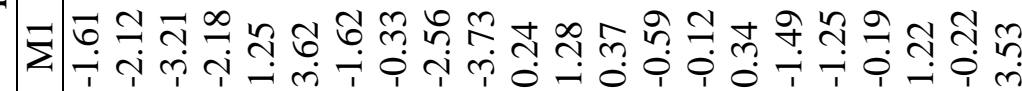

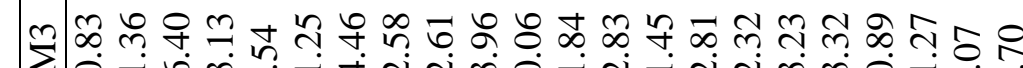
島 귱ำ 歌

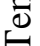

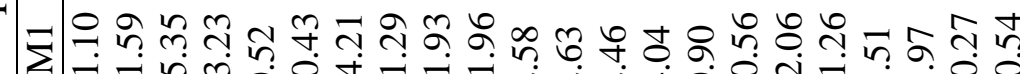

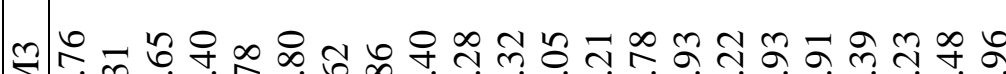
$\sum$ m m

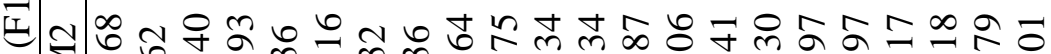
: $\Sigma$ त

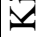

J กิ

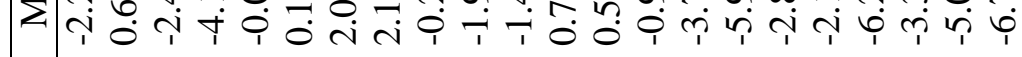
茫全 


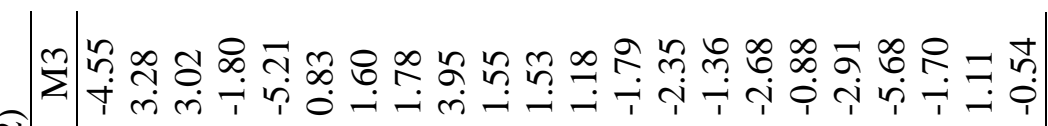
茛

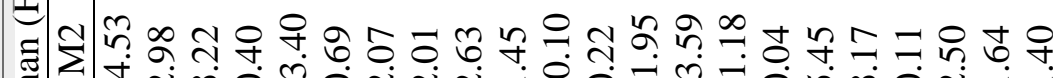
行

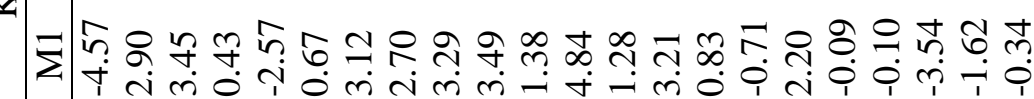

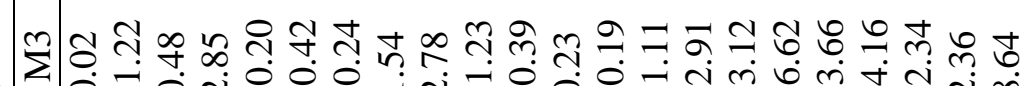
तิ

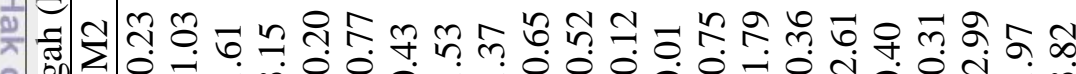

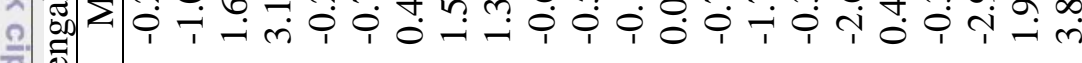

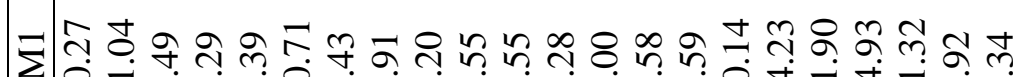

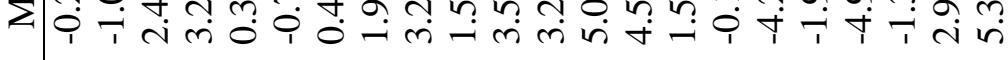

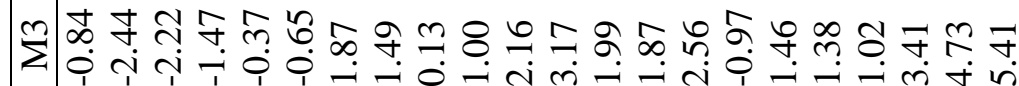
政

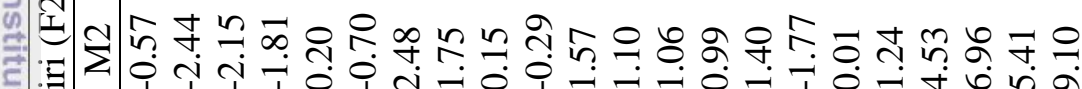
焉

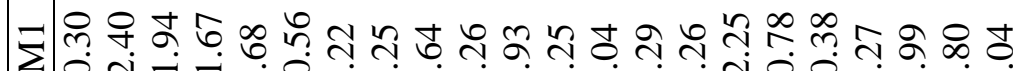
- इ

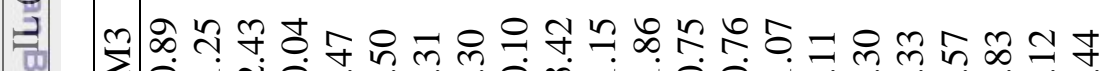

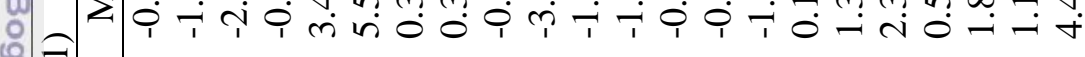
의

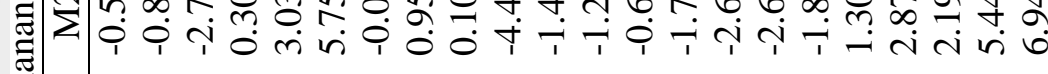
$\checkmark$

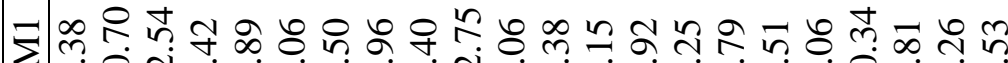
mi is

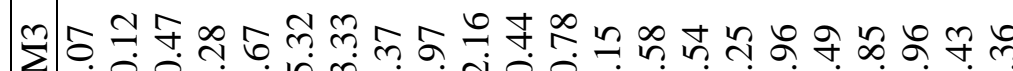

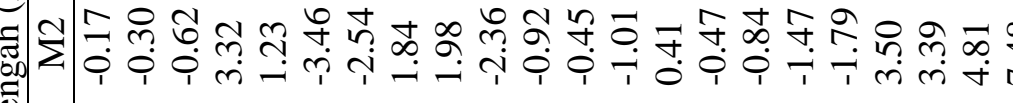

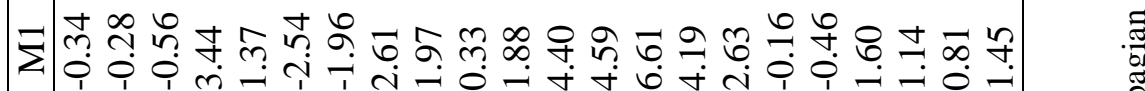

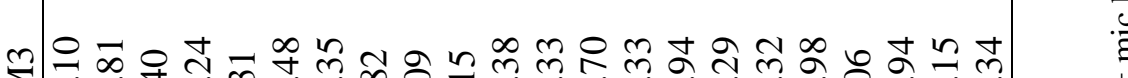

र

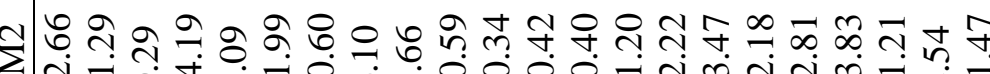

도

छี

II

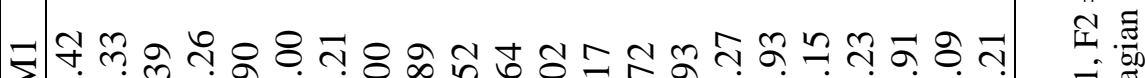

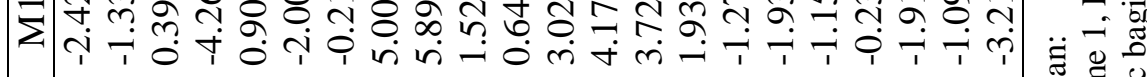
는 전 


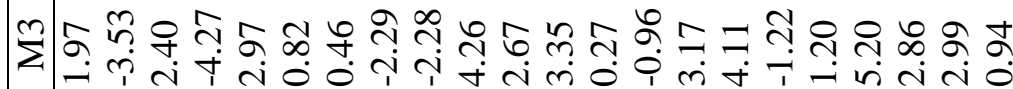

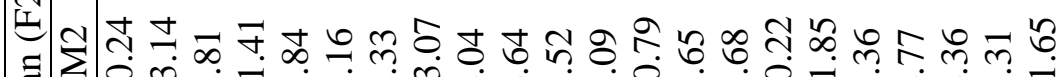

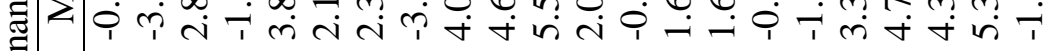
零

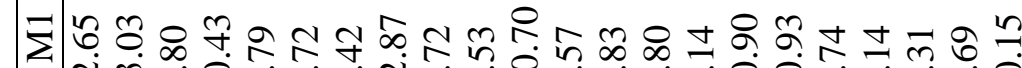
त 悉 สิ

0 T

式市

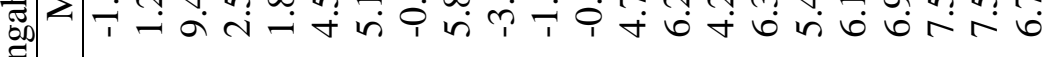
$\stackrel{0}{=}$

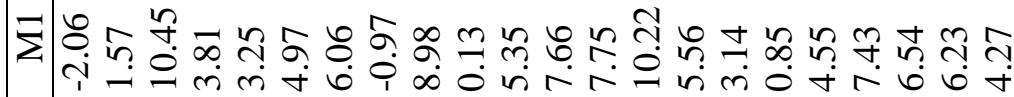

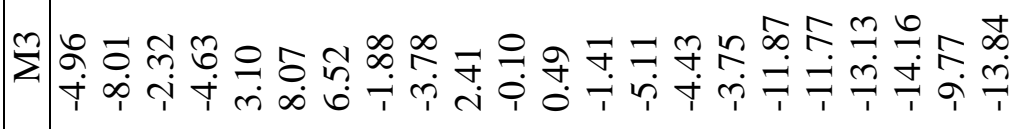
กิธ

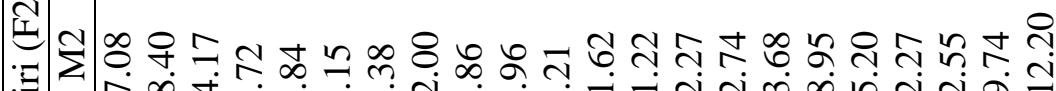
可

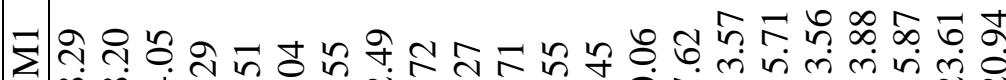
我

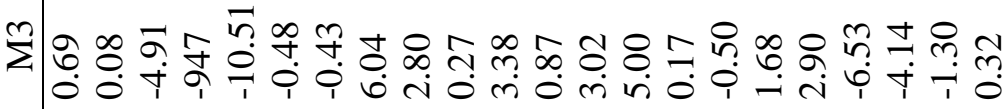
$\widehat{\widehat{\Xi}}$ 节 $\stackrel{\pi}{4}$

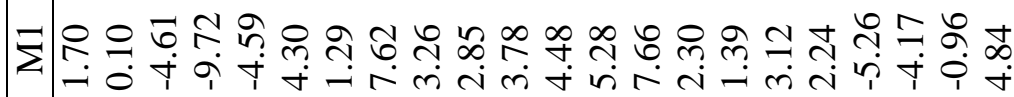

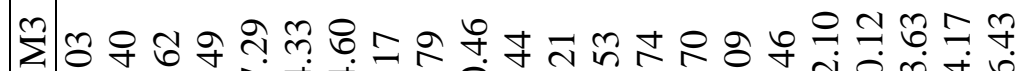
$\widehat{\overrightarrow{1}}$

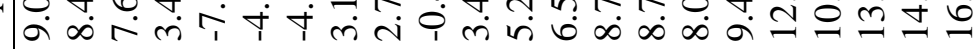

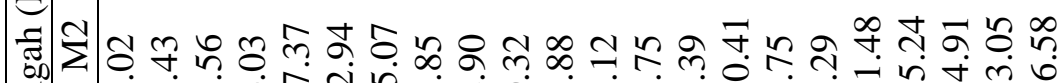
$=$ a ๑

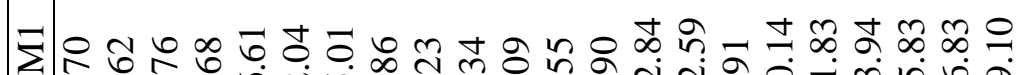

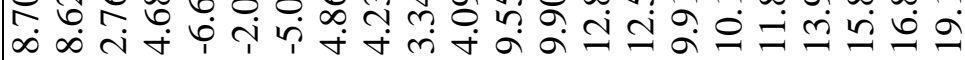

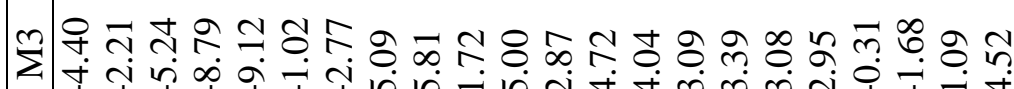

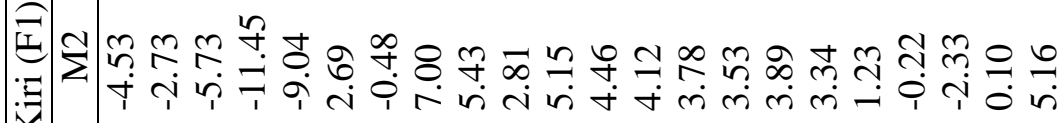
$\sqrt{2}$

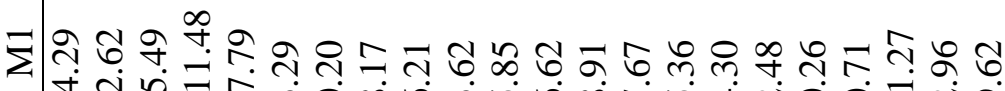
भं ப. 
m|

ชิ

ป

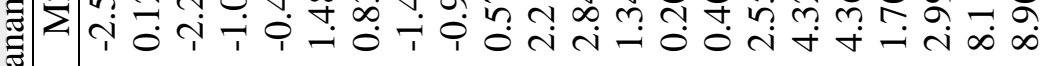

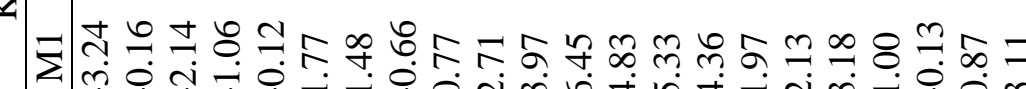

लि

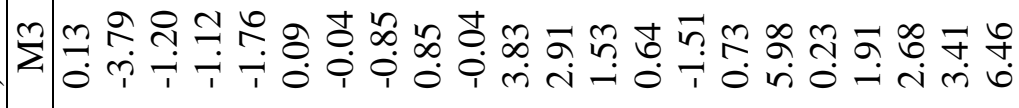

\لฟ

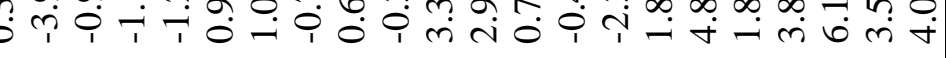

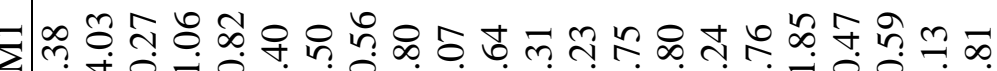

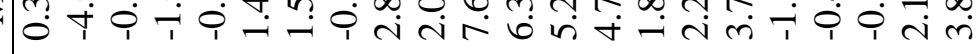

m人́

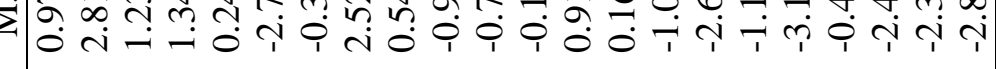

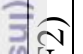

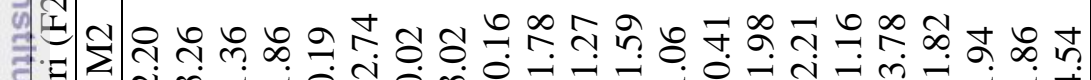
त

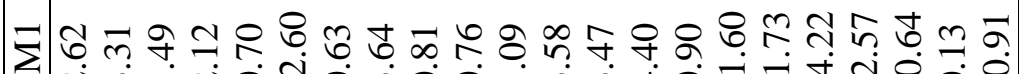
im

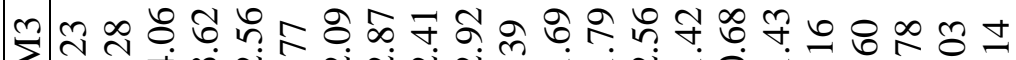

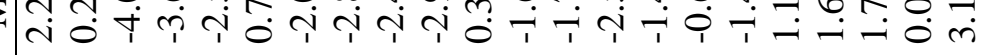

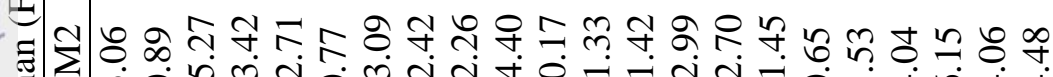

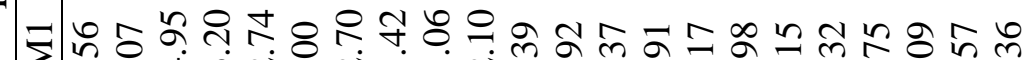

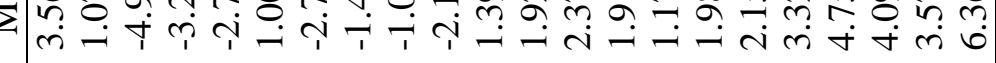

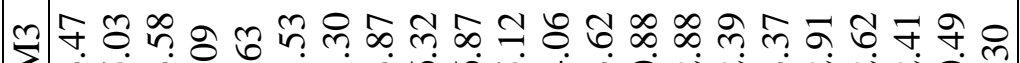

ले मि

政

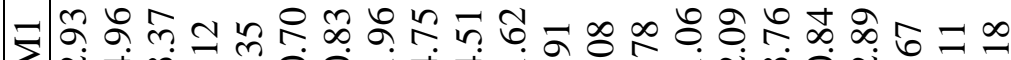
$\sum$ i

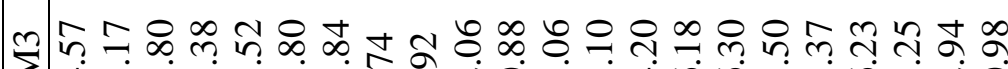
$\sum$ †

능 $m$ m $\sum$ मि

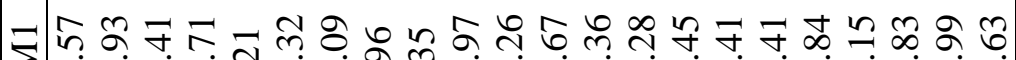
$\Sigma$ फित 


\section{RIWAYAT HIDUP}

Penulis dilahirkan di Medan, Provinsi Sumatera Utara, pada tanggal 20 November 1991. Penulis merupakan anak pertama dari pasangan Ayah Danang Bayu Saksono dan Ibu Desria Eka Rustanti. Penulis menempuh pendidikan sarjana (strata 1) pada tahun 2009 di Institut Pertanian Bogor, Fakultas Pertanian, Program Studi Arsitektur Lanskap, dan lulus pada tahun 2014. Penulis pernah bekerja di konsultan lanskap di Provinsi DKI Jakarta pada tahun 2014 hingga akhir tahun 2016. Pada Tahun 2017, Penulis melanjutkan studi magister di Frogram Studi Arsitektur Lanskap pada Sekolah Pascasarjana, Institut Pertanian Bogor. Pada Tahun 2019, Penulis mengikuti kegiatan seminar internasional "The $\mathrm{E}^{\mathrm{st}}$ International Seminar on Natural Resources \& Environmental Management (ASENREM)" sebagai oral presenter dengan judul Distribution of Noise on Residential Area in Bogor City (Case Study Residential Area that Close to $\bar{F}$ agorawi Highway and Pandu Road) yang diselenggarakan pada 15 Agustus 2019 , serta "The $4^{\text {th }}$ International Symposium for Sustainable Landscape Bevelopment (ISSLD)" sebagai oral presenter dengan judul Perception and Preference for Noise Impacts on Housing Residents in Bogor City (Case Study स्PB I Housing, Baranangsiang) yang diselenggarakan pada 10 Oktober 2019. 